\title{
AVALIAÇÃO DE RESÍDUOS DE ETILENOTIOURÉIA (ETU) EM FRUTAS COMERCIALIZADAS NA CIDADE DE SÃO PAULO
}

VERA REGINA ROSSI LEMES

Tese de Doutorado apresentada ao Departamento de

Saúde Ambiental da Faculdade de Saúde Pública da Universidade de São Paulo para obtenção do Grau de Doutor.

Área de concentração:

Saúde Ambiental

ORIENTADOR: PROF. DR. SÉRGIO COLACIOPPO

São Paulo 2007 
Autorizo, exclusivamente para fins acadêmicos e científicos, a reprodução total ou parcial desta dissertação, por processos fotocopiadores.

Assinatura:

Data: 


\section{AGRADECIMENTOS}

Agradeço ao Prof. Dr. Sérgio Colacioppo, pela confiança e orientação.

Ao Diretor do Instituto Adolfo Lutz, Carlos Adalberto de Camargo Sannazaro, ao Diretor da Divisão de Bromatologia e Química, Dr. Odair Zenebon, ao Diretor do Serviço de Química Aplicada, Paulo Tiglea e à Heloisa Helena Barretto de Toledo, Chefe da Seção de Aditivos e Pesticidas Residuais do Instituto Adolfo Lutz, por autorizarem a minha participação no curso de pós-graduação e a realização da parte experimental no Instituto Adolfo Lutz, e pelo apoio, confiança e incentivo.

Ao Hélio Alves Martins Júnior, químico e mestre em Ciências dos Materiais, da Applied Biosystems do Brasil, pela colaboração nas determinações no LC/MS/MS, apoio e amizade.

À Applied Biosystems do Brasil pelo apoio no suporte instrumental (LC/MS/MS).

À Scheilla Vitorino C. de Souza, doutora em Ciência dos Alimentos, Universidade Federal de Minas Gerais, pela colaboração no procedimento de avaliação da linearidade e pela atenção.

Ao Reinaldo Amauri Ribeiro, técnico de apoio à pesquisa do Instituto Adolfo Lutz, pela colaboração na realização das análises e pela amizade.

À Antonia de Lima Silva, auxiliar de serviço do Instituto Adolfo Lutz, pela colaboração na lavagem de vidrarias e pela amizade.

À minha mãe, Apparecida Eyde Rossi Lemes, pela colaboração nas compras das amostras.

Aos colegas do Laboratório de Resíduos de Pesticidas do Instituto Adolfo Lutz, pela compreensão.

À minha família e amigos, pelo carinho e paciência. 


\section{RESUMO}

Lemes, V.R.R. Avaliação de resíduos de etilenotiouréia (ETU) em frutas comercializadas na cidade de São Paulo. São Paulo, 2007 [Tese de Doutorado Faculdade de Saúde Pública da Universidade de São Paulo].

Etilenotiouréia (ETU) é uma substância tóxica, formada pela degradação e/ou biotransformação dos fungicidas etilenobisditiocarbamatos (EBDC). Seus resíduos podem ser encontrados em plantas e no ambiente, após o uso de EBDC na agricultura, ou em animais e no ser humano, quando expostos a esses produtos. Comprovadamente, a ETU tem a capacidade de induzir tumor na tireóide de roedores e no fígado de camundongo, apresentando evidência suficiente para carcinogenicidade em animais e evidência inadequada para carcinogenicidade em seres humanos. Os objetivos deste estudo foram: validar método analítico para determinação de resíduos de ETU nas matrizes estudadas; verificar a presença de resíduos de ETU em amostras de frutas (mamão, maçã e morango), coletadas em diferentes pontos de comercialização da cidade de São Paulo; avaliar os resultados e a contribuição de risco à saúde da população consumidora. Foram analisadas 90 amostras, sendo 30 de cada fruta (maçã, mamão e morango), adquiridas em diferentes pontos de comercialização da cidade São Paulo, no período de dezembro de 2005 a dezembro de 2006, distribuídas nas diferentes regiões do referido município e durante as estações do ano. Os parâmetros de validação avaliados foram: seletividade, linearidade, limite de quantificação, limite de detecção, exatidão e precisão. Os estudos de recuperação foram realizados com fortificações em três níveis (1, 2 e 10 LQ) em amostras controle. A determinação de resíduos de ETU foi feita por cromatografia a líquido de alto desempenho, com detector de absorção no ultravioleta (HPLC-UV) e cromatografia a líquido acoplada à espectrometria de massas em tandem (LC/MS/MS). Como todos os resultados obtidos por HPLC-UV

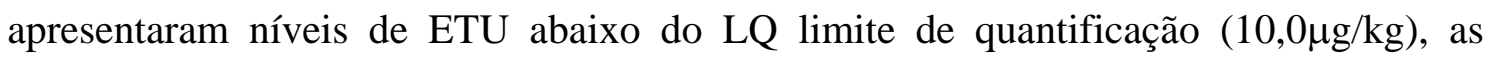
quantificações foram realizadas no LC/MS/MS, com limite de quantificação e de detecção respectivamente de $1,0 \mu \mathrm{g} / \mathrm{kg}$ e $0,5 \mu \mathrm{g} / \mathrm{kg}$. O método por LC/MS/MS mostrouse adequado para análise de ETU nos níveis de até 2,0 $\mu \mathrm{g} / \mathrm{kg}$ para maçã e morango e de até $10,0 \mu \mathrm{g} / \mathrm{kg}$ para mamão, com recuperações médias de 75 a 110\% e coeficientes de variação de 6 a 17\%. Foram encontrados resíduos de ETU em 10 (33\%) das amostras de maçã, em níveis que variaram de 1,0 a 3,7 $\mu \mathrm{g} / \mathrm{kg}$ (ppb); em 20 (67\%) das amostras de 


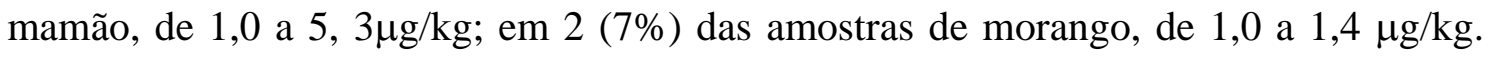
Estes valores estão abaixo do limite de $50 \mu \mathrm{g} / \mathrm{kg}$, estabelecido na União Européia. A estimativa da ingestão de resíduos de ETU pelo consumo das frutas estudadas, considerando o maior nível encontrado nesta pesquisa e dados fornecidos pelo IBGE, representam respectivamente 0,05 e 0,20 \% da IDA (Ingestão Diária Aceitável, estabelecida pelo Codex Alimentarius), para a população em geral e crianças. A estimativa da ingestão de resíduos de EBDC pelo consumo dos alimentos (maçã, tomate, mamão, alface, morango, banana, laranja, cenoura), monitorados pelo PARA no período de 2001 a 2004, considerando os maiores níveis encontrados e 100\% dos resíduos de ditiocarbamatos $\left(\mathrm{CS}_{2}\right)$ como sendo originários do uso de EBDC, foi de 7,2\% para a população em geral e de 28,9 \% para crianças. Dados de ETU e EBDC em outros alimentos, incluindo os industrializados, em água de consumo e em amostras ambientais, além de dados mais refinados de consumo alimentar para subgrupos mais sensíveis (como crianças e mulheres grávidas), são necessários para se avaliar o risco de maneira mais global e condizente com a realidade, em prol da Saúde Pública.

Descritores: Etilenotiouréia, Etilenobisditiocarbamatos, Mancozebe, Ditiocarbamatos, Agrotóxicos, Contaminantes em alimentos, Frutas, Saúde Pública, Meio Ambiente. 


\section{ABSTRACT \\ Lemes, V.R.R. Evaluation of ethylene thiourea (ETU) in fruits traded in the city of}

São Paulo. São Paulo, 2007. [Doctoral thesis, Faculty of Public Health of the University of São Paulo].

Ethylene thiourea (ETU) is a toxic substance generated by the degradation and/or biotransformation of ethylenebisdithiocarbamates (EBDC) fungicides. Their residues may be found in plants and in the environment after EBDC's use in agriculture or in animals and humans when exposed to such products. ETU is confirmedly able to induce tumors in rodents' thyroids and in mouse's liver, showing enough evidence of carcinogenicity in animals and inadequate evidence of carcinogenicity in humans. The aims of this study were validating an analytical method for determining ETU residues in the studied sources, verifying the presence of ETU residues in fruit samples (papaya, apple and strawberry) collected from different commercial centers in the city of São Paulo; evaluating the results and their contribution as a risk to the consumers' health. Ninety fruit samples (30 samples of each fruit - papaya, apple and strawberry) were analyzed. The samples were purchased at different commercial centers in different regions of the city of São Paulo and over all seasons during December 2005 through December 2006. The validation parameters used were selectivity, linearity, accuracy and precision. Recovery studies were carried out with fortifications in 3 levels (1, 2 and 10 times the Limit of Quantification, LQ) in control samples. The determination of ETU residues was carried out by high performance liquid chromatography, ultra-violet absorption detector (HPLC/UV) and liquid chromatography coupled on tandem mass spectrophotometry (LC/MS/MS). Since all results obtained through HPLC/UV showed levels of ETU below the LQ $(10.0 \mu \mathrm{g} / \mathrm{kg})$, quantification were carried out through LC/MS/MS with quantification and detection limits of $1.0 \mu \mathrm{g} / \mathrm{kg}$ and $0.5 \mu \mathrm{g} / \mathrm{kg}$, respectively. The LC/MS/MS method proved adequate for analyzing quantities of ETU as low as $2.0 \mu \mathrm{g} / \mathrm{kg}$ in apple and strawberry and $10.0 \mu \mathrm{g} / \mathrm{kg}$ in papaya, with average recovery of 75 to $110 \%$ and variation coefficients of 6 to $17 \%$. ETU residues were found in 10 (33\%) apple samples with levels ranging from 1.0 to $3.7 \mu \mathrm{g} / \mathrm{kg}$ (ppb); in 20 (67\%) of papaya samples with levels ranging from 1.0 to $5.3 \mu \mathrm{g} / \mathrm{kg}$ (ppb); and in 2 (7\%) strawberry samples with levels ranging from 1.0 to $1.4 \mu \mathrm{g} / \mathrm{kg}$ (ppb). These values are below the limit established in European Community (50 $\mu \mathrm{g} / \mathrm{kg}$ ). The assessment of ETU 
intake, considering the consumption informed by IBGE (Instituto Brasileiro de Geografia e Estatística, the Brazilian Institute for Geography and Statistics) and the highest level observed in total fruit samples in this research, represent $0.05 \%$ and 0.20 \% ADI (Acceptable Daily Intake, established by the Codex Alimentarius) for geral population and children, respectively. The assessment of EBDC intake, considering the consumption informed by IBGE (Instituto Brasileiro de Geografia e Estatística, the Brazilian Institute for Geography and Statistics) and the highest level observed in food samples (apple, tomato, papaya, lettuce, strawberry, banana, orange, carrot), monitoring from 2001 through 2004 year in the PARA (Programa de Análise de Resíduos de Agrotóxicos em Alimentos, Program Monitoring of Pesticide Residues in Food, Brazil), and that $100 \%$ of dithiocarbamate $\left(\mathrm{CS}_{2}\right)$ residues from EBDC's use, represent $7.2 \%$ and 28.9\% ADI for geral population and children, respectively. ETU and EBDC data in other foods (including industrialized foods), water and environment samples, together with more refined food consumption data considering more sensitive population subgroups (as children and pregnants) are necessary to evaluate the risk in a more global and realistic way in favor of Public Health.

Keywords: Ethylene thiourea, Ethylenebisditiocarbamates, Mancozeb, Dithiocarbamates, Pesticides, Contaminants in foods, Fruits, Public Health, Environment 


\section{ÍNDICE}

1. INTRODUÇÃO 1

1.1. Resíduos de agrotóxicos em alimentos 4

1.1.1 Legislação e normas referentes aos Limites Máximos de Resíduos (LMR) de agrotóxicos nos alimentos

1.2. Ditiocarbamatos 6

$\begin{array}{ll}\text { 1.2.1. Dimetilditiocarbamatos } & 7\end{array}$

$\begin{array}{ll}\text { 1.2.2. Etilenobisditiocarbamatos (EBDC) } & 7\end{array}$

1.2.3. Outros ditiocarbamatos $\quad 8$

1.2.4. Limites Máximos de Resíduos (LMR) de ditiocarbamatos nos alimentos 8

1.3. Degradação dos etilenobisditiocarbamatos (EBDC) 12

$\begin{array}{lll}\text { 1.4. Etilenotiouréia (ETU) } & 14\end{array}$

1.4.1. Formação de ETU na fabricação e durante o armazenamento 14

1.4.2. Resíduos remanescentes de EBDC e ETU após a aplicação 15

1.4.3. Formação de ETU no preparo e/ou industrialização de alimentos 16

1.4.4. Métodos para minimizar ou remover os resíduos de EBDC e ETU 17

$\begin{array}{lll}\text { 1.5. } & \text { Toxicidade de EBDC } & 18\end{array}$

$\begin{array}{lll}1.6 & \text { Toxicidade da ETU } & 19\end{array}$

1.7. Níveis de EBDC e ETU administrados em mamíferos para alguns efeitos adversos à saúde $\quad 27$

1.8 Estudos relacionados à exposição humana a EBDC e/ou à ETU 28

1.9. Prováveis riscos ao meio ambiente 30

1.9.1 Degradação de ETU no meio ambiente 32

1.9.2 Estudos de toxicidade de EBDC e ETU no ambiente 34 
1.10.1. Mercado mundial de frutas $\quad 40$

1.10.2. Escolha das matrizes de estudo - Frutas 44

1.10.3. Hábitos de consumo relativos às frutas estudadas 47

1.10.4 A cultura de maçã (Malus Silvestris Mill.) 48

1.10.5 A cultura de mamão 50

1.10.6 A cultura de morango (Fragaria Vesca L.) 53

1.11. Doenças nas culturas 56

1.11.1. Principais doenças que afetam a cultura de maçã 56

1.11.2. Principais doenças que afetam a cultura de mamão 58

1.11.3. Principais doenças que afetam a cultura de morango 59

1.12. Uso de agrotóxicos em frutas 62

1.13. Medidas para redução dos níveis de resíduos de agrotóxicos nas frutas

1.13.1. Uso correto e seguro de agrotóxicos 64

1.13.2 Produção Integrada de Frutas no Brasil 65

1.14. Principais estudos de monitoramento de resíduos $\begin{array}{ll}\text { de agrotóxicos em alimentos } & 68\end{array}$

1.14.1. Principais estudos de resíduos de ditiocarbamatos em frutas 70

1.14.2. Alguns estudos de ditiocarbamatos em outros vegetais (exceto frutas) 72 
1.15. Estimativas para avaliar o risco de exposição pela ingestão de alimentos com resíduos de agrotóxicos

1.15.1. Estimativas da ingestão diária de agrotóxicos a longo prazo (ou crônica) 75

1.15.2. Estimativa da ingestão diária a curto prazo (ou aguda) 78

2. OBJETIVOS 79

2.1. Objetivo Geral 79

2.2. Objetivos específicos 79

3. METODOLOGIA 80

3.1. Matriz de estudo - Frutas 80

3.1.1. Critérios para escolha das frutas 80

3.1.2 Planejamento da amostragem 80

3.1.3. Preparação das amostras (de laboratório) 86

3.2. Material e Métodos 86

3.2.1. Material 86

3.2.2. Método para determinação de resíduos de etilenotiouréia (ETU)

3.3. Validação de método analítico para determinação de etilenotiouréia em frutas

3.3.1. Número de amostras para os ensaios de validação do método

3.3.2. Seletividade

3.3.3. Estudo da faixa de linearidade de resposta do detector

3.3.4 Construção da curva analítica

3.3.5 Limite de Quantificação (LQ) 
3.3.7. Exatidão 97

$\begin{array}{lll}\text { 3.3.8. } & \text { Precisão } & 98\end{array}$

3.4. Avaliação de risco de exposição à ETU através da ingestão de frutas 99

3.4.1 Estimativa de risco pela ingestão de maçã, mamão e morango 99

3.4.2 Estimativa do risco de exposição a EBDC pelos resultados obtidos nos alimentos analisados pelo PARA (2001-2004)

3.4.3. Estimativa do risco de exposição a ETU (calculada) pelos resultados obtidos nos alimentos analisados pelo PARA (2001-2004)

4. RESULTADOS E DISCUSSÃO 101

4.1. Otimização das condições analíticas 102

4.2. Parâmetros avaliados para validação do método analítico: seletividade, linearidade, intervalo de trabalho, exatidão e precisão, limite de detecção e de quantificação

4.3. Resíduos de etilenotiouréia (ETU) em frutas comercializadas na cidade de São Paulo

4.4. Avaliação de risco de exposição à ETU pela ingestão de frutas

5. CONCLUSÕES

6. RECOMENDAÇÕES

7. REFERÊNCIAS BIBLIOGRÁFICAS 
ANEXOS

Anexo 1 Ingredientes ativos de agrotóxicos registrados para uso em maçã, mamão e morango

Anexo 2 Redes de supermercados onde foram adquiridas as amostras

Anexo 3 Resultado das amostras de maçã, de acordo com o local, zona, estação do ano

Anexo 4 Resultado das amostras de mamão (Papaya carica L), de acordo com o local, zona, estação do ano

Anexo 5 Resultado das amostras de morango, de acordo com o local, zona, estação do ano 


\section{LISTA DE TABELAS}

Tabela 1 Características físico-químicas dos dimetilditiocarbamatos

Tabela 2 Características físico-químicas dos etilenobisditiocarbamatos autorizados para uso no Brasil

Tabela 3 Características físico-químicas do metam sódico e do propinebe

Tabela 4 Limites Máximos de Resíduos de ditiocarbamatos permitidos no Brasil e os estabelecidos pelo Codex Alimentarius em culturas de frutas

Tabela 5 Limites Máximos de Resíduos de ditiocarbamatos permitidos no Brasil e os estabelecidos pelo Codex Alimentarius em culturas de vegetais

Tabela 6 Limites Máximos de Resíduos de ditiocarbamatos permitidos no Brasil e os estabelecidos pelo Codex Alimentarius em culturas de cereais e outras

Tabela 7 Ensaios que evidenciam efeitos carcinogênicos em animais de experimentação expostos à ETU

Tabela 8 Efeitos mutagênicos em ensaios in vitro e em animais de experimentação expostos à ETU

Tabela 9 Efeitos teratogênicos em animais de experimentação associados à exposição à ETU

Tabela 10 Efeitos adversos à saúde observados em animais expostos à ETU

Tabela 11 Doses de EBDC e ETU para alguns efeitos críticos estudados em mamíferos 
Tabela 12 Estudos de toxicidade de etilenobisditiocarbamatos e de ETU e EU em peixe, crustáceos, algas e bactérias

Tabela 13 Doses de referência de ETU

Tabela 14 Classificação das principais frutas produzidas no

Brasil em ordem decrescente e comparação com a produção mundial

Tabela 15 Composição da parte comestível das frutas estudadas:

calorias, nutrimentos, minerais, vitaminas, aminoácidos e porcentagem de resíduo

Tabela 16 Consumo e custo de agrotóxicos das principais classes de princípios ativos utilizados nas culturas de frutas em relação ao total utilizado no Brasil em 2000

Tabela 17 Número de amostras para realização dos ensaios de validação

Tabela 18 Parâmetros otimizados para a ETU no modo MRM

Tabela 19 Estatísticas da análise de variância da regressão, incluindo teste de desvio da linearidade, para curva de ETU (1,0 ng/mL a 25,0 ng/mL) em solventes

Tabela 20 Distribuição dos resultados das recuperações de ETU, desvio-padrão e coeficiente de variação (n=6), de acordo com o nível de fortificação por HPLC-UV e LC/MS/MS

Tabela 21 Número (N) e porcentagem (\%) de amostras com resíduos de ETU, mediana, média, desvio-padrão, coeficiente de variação, média geométrica e valores mínimos e máximos por LC-MS/MS 
Tabela 22 Estimativa da ingestão de ETU pelo consumo de maçã, mamão e morango, em \% da IDA e da dose oral crônica de efeito não carcinogênico (Drf)

Tabela 23 Avaliação de risco de exposição a EBDC pelos resultados obtidos nos alimentos analisados pelo PARA (2001- 2004)

Tabela 24 Avaliaçao risco de exposição à ETU (calculada) pelos resultados obtidos nos alimentos analisados no período de 2001 a 2004 no PARA (ANVISA 2005) 


\section{LISTA DE FIGURAS}

Figura 1 Degradação dos EBDC e formação de ETU

Figura 2 Produtos de reações de ETU em sistemas biológicos e não biológicos

Figura 3 Principais produtores mundiais de maçã, mamão, morango em porcentagem relativa

Figura 4 Macieira

Figura 5 Frutos da macieira

Figura $6 \quad$ Flores da macieira

Figura 7 Ramos em flor da macieira

Figura 8 Maçãs

Figura $9 \quad$ Cultura de mamão 51

Figura $10 \quad$ Frutos do mamoeiro 51

Figura $11 \quad$ Mamões C.Papaya L 52

Figura 12 Plantação de morango 53

Figura 13 Plantação de morangos - com proteção aérea 54

Figura 14 Morangos 56

Figura 15 Distribuição dos locais de amostragem de acordo com o bairro da cidade de São Paulo, no período de 21/12/2005 a $19 / 12 / 2006$

Figura 16 Número de amostras coletadas de acordo com a estação do ano, no período de 21 de dezembro de 2005 a 19 de dezembro de 2006, $(\mathrm{n}=90)$

Figura 17 Número de Amostras coletadas de acordo com a região da cidade de São Paulo-SP, no período de 21 dezembro de 2005 a 19 de dezembro de 2006, $(n=90)$ 
Figura 18 Distribuição dos locais de amostragem de acordo com a região (zona) da cidade de São Paulo no período de 21/12/2005 a 19/12/2006 (n=90)

Figura 19 Fluxograma das etapas do procedimento analítico para determinação de resíduos de ETU (LEMES 2003, com adaptações)

Figura 20 Cromatograma referente ao padrão de ETU na concentração de 20,0ng/mL por HPLC-UV 103

Figura 21 Espectro de massas MS da molécula protonada $[\mathrm{M}+\mathrm{H}]^{+}$ da ETU obtido em ionização por electrospray no modo de íons positivos

Figura 22 Espectro de massas MS/MS da ETU obtido com o rampeamento da energia de colisão de 5 a 130 eV

Figura 23 Espectros de massas do padrão de ETU à concentração de 25,0 ng/mL obtido em modo MRM

Figura 24 Cromatogramas do padrão de ETU e das amostras controle por HPLC-UV nas condições cromatográficas descritas no item 4.1.

Figura 25 Cromatograma do branco do procedimento completo por LC/MS/MS, nas condições descritas no item 4.1.

Figura 26 Cromatograma do padrão de ETU na concentração de

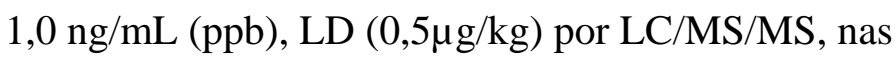
condições descritas no item 4.1.

Figura 27 Cromatograma da amostra controle de maçã por LC/MS/MS, nas condições descritas no item 4.1. 
Figura 28 Cromatograma da amostra controle de morango, nas condições descritas no item 4.1.

Figura 29 Cromatograma da amostra controle de mamão por

LC/MS/MS, nas condições descritas no item 4.1.

Figura 30 Gráfico exploratório dos resíduos da regressão da curva de ETU (1,0 ng/mL a 25,0 ng/mL) em solventes, com indicação dos respectivos outliers diagnosticados pelo teste de resíduos padronizados Jacknife

Figura 31 Gráfico de probabilidade normal da curva de ETU (1,0 ng/mL a 25,0 ng/mL) em solventes e matrizes

Figura 32 Gráfico de Durbin-Watson da curva de ETU (1,0 ng/mL a 25,0 ng/mL) em solventes

Figura 33 Curva analítica de ETU (transição de quantificação: 103,1> 44,0), na faixa de $1,0 \mathrm{ng} / \mathrm{mL}$ a $25,0 \mathrm{ng} / \mathrm{mL}$, com respectivas equações e coeficientes de determinação

Figura 34 Curva da Transição de Confirmação da ETU por LC/MS/MS: $103.1>86.0$

Figura 35 Curva da 2.a Transição de Confirmação da ETU por LC/MS/MS: $103.1>60.0$

Figura 36 Curva analítica de ETU por HPLC-UV, 10,0 a $250,0 \mathrm{ng} / \mathrm{mL}$

Figura 37 Cromatograma do padrão de ETU na concentraçã de 2,0 ng/mL, (ppb), LD (1,0 $\mu \mathrm{g} / \mathrm{kg})$ por LC/MS/MS, nas condições descritas no item 4.1. 
Figura 38 Cromatograma da amostra de maçã com 3,7 $\mu$ g/kg

de ETU (anexo 3), analisada por LC/MS/MS

Figura 39 Cromatograma da amostra de morango com

1,4 $\mu \mathrm{g} / \mathrm{kg}$ de ETU (anexo 5), analisada por LC/MS/MS

Figura 40 Distribuição dos níveis de ETU ( $\mu \mathrm{g} / \mathrm{kg})$ por LC/MS/MS, encontrados nas amostras de maçã

Figura 41 Distribuição dos níveis de ETU ( $\mu \mathrm{g} / \mathrm{kg}$ ) por LC/MS/MS, encontrados nas amostras de mamão

Figura 42 Distribuição dos níveis de ETU ( $\mu \mathrm{g} / \mathrm{kg}$ ) por LC/MS/MS, encontrados nas amostras de morango

Figura 43 Amostras (\%) com níveis de ETU > LQ de acordo com a estação do ano, no período de 21/12/2005 a

$19 / 12 / 2006$

Figura 44 Amostras (\%) com níveis de ETU de acordo com a região da cidade de São Paulo-SP, no período de 21/12/2005 a 19/12/2006

Figura 45 Estimativas de risco de exposição à ETU e a EBDC em \% IDA, obtidas pelo resultado deste estudo e pelos obtidos nos alimentos monitorados pelo PARA 


\section{LISTA DE SIGLAS E ABREVIATURAS}

ANDEF-Associação Nacional de Defesa Vegetal Boa Prática Agrícola.

ANVISA - Agência Nacional de Vigilância Sanitária

API - Ionização à Pressão Atmosférica

ARfD - Refecence Dose for Acute Oral Exposure (Dose de Referência Oral Aguda)

BfR - Federal Institute for Risk Assessment (Instituto Federal para Avaliação de Risco,

Inglaterra)

BPA - Boas Práticas Agrícolas

CCPR - Comissão do Codex Alimentarius para Resíduos de Pesticidas

CG/MS - Gas Chromatography/ Mass Spectrometry (Cromatografia a gás / Espectrometria de Massas (CG/MS).

CE - Concentração Efetiva de Exposição

CE - Energia de Colisão

CL - Concentração Letal

CEAGESP - Companhia de Entrepostos e Armazéns Gerais de São Paulo

CEASA - Companhia de Entrepostos e Armazéns Gerais Sociedade Anômina

CL - Concentração Letal

$\mathrm{CS}_{2}$ - Dissulfeto de Carbono

CV - Coeficiente de Variação

CXP - Potencial de Saída da Cela de Colisão

DIDT - Etileno bistiouram dissulfeto

DL - Dose Letal

DMDC - Dimetilditiocarbamatos

DP - Potencial do Orifício 
Drf - Dose Oral Crônica ou RfD - Reference Dose for Chronic Oral Exposure (Dose Oral de Referência Crônica)

EBDC - Etilenobisditiocarbamatos

ECD - Detector de Captura de Elétrons

EDA - Etileno diamina

EDI - Etileno diisocianato

EMBRAPA - Empresa Brasileira de Pesquisa Ambiental

ENDEF - Estudo Nacional da Despesa Familiar

EPA- Environmental Protection Agency (Agência de Proteção Ambiental)

EPI - Equipamento de Proteção Individual

ETU - Etilenotiouréia

EU - Etilenouréia

FAO/WHO - Food and Agriculture Organization of United Nations/World Health Organization (Organização das Nações Unidas para a Agricultura e Alimentação da Organização Mundial da Saúde)

FDA - Administração de Drogas e Alimentos

GARP - Associação Grupo de Analistas de Resíduos de Pesticidas

GEMS/FOOD - Global Environment Monitoring System/Food Contamination and Assessment Program/ Alimentos (Sistema de Monitorameto do Meio Ambiente/ Programa de Avaliação da Contaminação de Alimentos)

HPLC - High Performance Liquid Chromatography (Cromatografia a Líquido de Alto Desempenho)

HPLC-UV - High Performance Liquid Chromatography with Ultra Violet Detector (cromatografia a líquido de alto desempenho com detector ultravioleta) $\mathrm{H}_{2} \mathrm{~S}$ - Sulfeto e Hidrogênio 
IARC - International Agency for Research on Cancer (Agência Internacional de Pesquisa com câncer)

IBGE - Instituto Brasileiro de Geografia e Estatística

ICH - International Conference on Harmonization of Technical Requirements for Registration of Pharmaceuticals for Human Use (Conferência Internacional para Harmonização de Requerimentos Técnicos para Registro de Produtos Farmacêuticos para Uso Humano).

IDA - Ingestão Diária Aceitável

INMETRO - Instituto Nacional de Metrologia, Normalização e Qualidade Industrial.

IUPAC - International Union of Pure and Applied Chemistry (União Internacioanl de Química Pura e Aplicada)

JMPR Joint Meeting of the FAO Panel of Experts on Pesticide Residues in Food (Grupo de Trabalho de Especialistas em Resíduos de Pesticidas em Alimentos da FAO) JNCI - Journal of the National Cancer Institute (Jornal do Instituto Nacional do Câncer) LC/MS/MS - Liquid Chromatography coupled tandem Mass Spectrometry technique (Cromatografia a Líquido acoplada à espectrometria de massas em tandem) LD - Limite de Detecção

LMR - Limite Máximo de Resíduo

LOAEL - Lowest OBserved Adverse Effect Level (Menor Nível de Efeito Adverso Observado)

LOEL or LEL - Lowest OBserved Effect Level (Menor Nível de Efeito Observado)

LQ - Limite de Quantificação

MAFF - Ministry of Agriculture, Fisheries \& Food. Advisory Committee (Ministério da Agricultura, Pesca e Alimentos- Comitê Consultivo)

MAPA - Ministério da Agricultura, Pecuária e Abastecimento MEDI - Maximum Estimated Daily Intake (Ingestão Diária Máxima Estimada) 
MIP - Manejo Integrado de Pragas

MMQO - Método dos Mínimos Quadrados Ordinários

MRM - Monitoramento de Reações Múltiplas

MS - Ministério da Saúde

MTE - Ministério do Trabalho e Emprego

$\mathrm{m} / \mathrm{z}=$ relação massa/carga

NEDI - National Estimated Daily Intake (Ingestão Diária Estimada Nacional)

NESTI - National Estimates of Short-Term Intake (Estimativa da ingestão diária a curto prazo ou aguda)

NFPA - Associação Nacional dos Alimentos Processados

NIOSH /RTECS - Registry of Toxic Effects of Chemical Substances (Registro de Substâncias Químicas com Efeitos Tóxicos)

NOAEL - Highest Level of no Observed Adverse Effect (Maior Nível no qual não se Observa o Efeito Adverso)

NOEL - Highest Level of no Observed Effect (Maior Nível no qual não se Observa o Efeito)

NPD - Detector de Nitrogênio e Fósforo

NTIS - National Technical Information Service (Serviço Nacional de Informações Técnicas)

NTP-TR - National Toxicology Program Technical Report Series (Programa Nacional de Toxicologia- Relatório Técnico)

PARA - Programa de Análise de Resíduos de Agrotóxicos em Alimentos

PIF - Produção Integrada de Frutas

PIM - Produção Integrada de Maçã

PP - Programa Paulista de Análise Fiscal de Alimentos

PP0304 - Programa Paulista de Análise Fiscal de Alimentos Biênio 2003-2004

PSD - Pesticide Safety Directorate (Reino Unido) (Diretoria de Segurança de Pesticidas)

PTFE - Politetrafluoretileno

PTU - Propilenotiouréia 
Q - Quadrupolo

$R^{2}$ - Coeficiente de Determinação

RDC - Resolução da Diretoria Colegiada

RE - Resolução

SEAGRI - Secretaria da Agricultura, Irrigação e Reforma Agrária da Bahia.

SIDRA - Sistema IBGE de Recuperação Automática

SINDAG - Sindicato Nacional da Indústria de Produtos para Defesa Agrícola

SRJUNDIAÍ - Sindicato Rural de Jundiaí

TMDI - Theorical Maximum Daily Intake (Ingestão Diária Máxima Teórica)

T3 - Triiodotironina, hormônio da tireóide

T4 - Tiroxina, hormônio da tireóide

TSH - Hormônio Estimulador da Tireóide

USA - United States of América (Estados Unidos da América)

USDA - United States Department of Agriculture (USA) (Departamento da

Agricultura dos Estados Unidos da América)

WHO - World Health Organization (Organização Mundial da Saúde) 


\section{INTRODUÇÃO}

A saúde é um direito humano fundamental, definida pela Organização Mundial da Saúde (WHO) como "um estado de completo bem estar físico, mental e social do indivíduo e não apenas a ausência de doença". É o maior recurso para o desenvolvimento social, econômico e pessoal, assim como importante dimensão da qualidade de vida. Assim, a qualidade dos alimentos e a dieta e a qualidade do meio ambiente, são elementos essenciais, entre outros, para compreender a saúde pública num contexto amplo. $\mathrm{O}$ consumo de alimentos é essencial à preservação da vida e o consumo de frutas traz inúmeros benefícios à saúde, pois são ricas em vitaminas e minerais, entre outros componentes (DECLARAÇÃO DE ADELAIDE 1988; DECLARAÇÃO DE SUNDSVALL 1991 apud MINISTÉRIO DA SAÚDE 2001).

Por outro lado, o alimento é a principal fonte de exposição da população a produtos químicos e a vigilância dos resíduos de agrotóxicos nos alimentos constitue um dos métodos mais importantes para estimar os riscos conseqüentes para a saúde humana. Quando o nível observado é inaceitável, medidas apropriadas devem ser tomadas para identificar a causa e promover ações que minimizem a exposição da população em geral.

As políticas públicas devem garantir acesso universal a quantidades de alimentos de boa qualidade e que respeitem as peculiaridades culturais de cada região. Políticas de alimentação e nutrição que integrem harmonicamente a agricultura, a economia e o meio ambiente devem ser prioridades de todos os governos para obter o melhor impacto na saúde nacional e internacional. Desde 1986, a Carta de Ottawa tem servido como fonte orientadora e inspiradora para a promoção da saúde. Conferências e reuniões internacionais subseqüentes têm deixado clara a relevância das principais estratégias em promoção da saúde, incluindo políticas públicas positivas e meio ambiente favoráveis. (DECLARAÇÃO DE ADELAIDE 1988; DECLARAÇÃO DE SUNDSVALL 1991 apud MINISTÉRIO DA SAÚDE 2001).

A presença de pragas nas culturas pode comprometer significativamente a produção de alimentos e sua qualidade, tanto no campo quanto durante o transporte e armazenamento (GEMS/FOOD/WHO 1997). 
Peres, em estudo realizado em 2005, afirma que a produtividade agrícola atual é suficiente para suprir as demandas mundiais de alimento e que a fome não é um problema de produção e sim um problema de distribuição de riquezas. Relata que, segundo a Organização das Nações Unidas para a Agricultura e Alimentação da Organização Mundial da Saúde (FAO/WHO), foram produzidas em 2001 aproximadamente nove trilhões de toneladas de produtos agrícolas, provenientes de lavouras primárias (sem beneficiamento) (FAO/WHO 2003 apud PERES 2005) e, considerando apenas 5\% deste montante, correspondentes a aproximadamente 450 milhões de toneladas/ano, resultaria em aproximadamente $200 \mathrm{~kg}$ de alimento disponível por habitante por dia, levando em conta uma população de pouco mais que seis bilhões de pessoas. (PERES 2005).

O Brasil ocupa a terceira posição mundial no consumo de agrotóxicos, depois dos Estados Unidos e do Japão e o oitavo lugar em uso por área cultivada (3,2 kg/ha de agrotóxicos). De acordo com o Sindicato Nacional da Indústria de Produtos para Defesa Agrícola (SINDAG), em 2003 existiam no Brasil 600 produtos em linha de comercialização, sendo $19 \%$ da classe toxicológica I (extremamente tóxicos), $26 \%$ da classe toxicologógica II (altamente tóxicos), 32\% da classe toxicológica III (moderadamente tóxicos), e $23 \%$ da classe toxicológica IV (pouco tóxicos). Comparando os dados de 2003 com os de 1992, observa-se que os produtos das classes toxicológicas IV, III e II tiveram aumento em número de 72, 49 e 13, respectivamente, e os da classe toxicológica I diminuíram em número de 13 (SINDAG 2007).

O uso generalizado e intensivo de agrotóxicos pode ocasionar a resistência de espécies combatidas às substâncias empregadas e danos em espécies não visadas. $\mathrm{O}$ desequilíbrio ecológico pode agravar o surgimento e proliferação de pragas e doenças e, conseqüentemente, aumentar a necessidade de uso de agrotóxicos (GARCIA 2001).

O impacto do uso de agrotóxicos sobre a saúde humana é um problema que tem merecido atenção da comunidade científica em todo o mundo. Eles podem causar efeitos tóxicos em humanos, nos animais domésticos e silvestres, nos organismos aquáticos e ao ambiente. Os trabalhadores que manipulam esses produtos 
nas indústrias, os aplicadores que manuseiam e aplicam formulações de agrotóxicos nas lavouras ou em campanhas de saúde pública e a população rural vizinha de plantações onde esses produtos são utilizados ou produzidos são os principais grupos de risco de exposição aguda.

As políticas agrícolas devem não apenas priorizar critérios de produção mas, também, a proteção da saúde dos trabalhadores rurais, da população em geral e do meio ambiente. Além disso, os custos com a saúde e com a recuperação do meio ambiente não são freqüentemente levados em consideração. Pingali e col. (1994), por exemplo, avaliaram o benefício líquido do uso de inseticidas e herbicidas na produção de arroz nas Filipinas, tendo verificado que com a aplicação de duas doses recomendadas de inseticidas, o lucro aumentaria em 492 pesos. Em contrapartida, o custo com a saúde aumentaria em 765 pesos, gerando, assim, uma perda líquida de 273 pesos (PINGALI e col. 1994 apud SOARES e col. 2003). Soares, em 2001, estimou o custo social do uso dos agrotóxicos em Minas Gerais e concluiu que o custo da intoxicação do trabalhador rural representou cerca de $40 \%, 25 \%$ e $24 \%$ do benefício do uso de organofosforados e carbamatos nas culturas de abobrinha, milho e feijão, respectivamente (SOARES e col. 2003).

No cenário internacional, é cada vez mais valorizado o aspecto qualitativo e o respeito ao meio ambiente, na produção de qualquer produto. São necessários: o aperfeiçoamento dos mercados, a mudança de hábitos e a produção de alimentos seguros. Normas européias têm pressionado exportadores de frutas e hortaliças para o estabelecimento de regras de produção que levem em consideração os resíduos de agroquímicos, o meio ambiente e as condições de trabalho e de higiene (EMBRAPA 2005c).

O crescimento da cadeia produtiva de frutas do país no mercado mundial foi impulsionado pela implantação do programa de Produção Integrada de Frutas (PIF) (MAPA 2007e).

$\mathrm{O}$ aumento da produção de frutas representa uma responsabilidade maior com a qualidade e sanidade das mesmas, uma vez que irá atingir maior número de consumidores. 
Apesar da melhora, nos últimos anos, das informações sobre resíduos de agrotóxicos nos alimentos, por intermédio de programas de monitoramento, faltam dados de consumo de subgrupos de risco importantes, como crianças e bebês. A carência de dados mais completos sobre os resíduos de agrotóxicos nos alimentos e sobre o consumo não permite estimar o risco à saúde em relação aos resíduos de agrotóxicos de uma maneira mais condizente com a realidade.

\subsection{Resíduos de agrotóxicos em alimentos}

A presença de resíduos de agrotóxicos nos alimentos preocupa o consumidor e as autoridades de saúde, já que são substâncias tóxicas e podem oferecer riscos à saúde humana e ambiental. Fatores como: clima, densidade de pragas nas diferentes culturas, técnicas de aplicação e ou utilização, características físico-químicas de cada princípio ativo, características toxicológicas como: toxicocinética (polaridade, metabolismo, persistência), toxicodinâmica (ação tóxica sistêmica ou local) e condições ambientais, podem influenciar na ocorrência e nos teores dos referidos resíduos.

Resíduo de agrotóxico é qualquer substância no alimento, produto agrícola ou alimento de origem animal resultante do uso de um princípio ativo (produto formulado). O termo inclui quaisquer derivados de um agrotóxico, tais como produtos de conversão, metabólitos e impurezas que devem ser considerados quando apresentam importância toxicológica (GEMS/FOOD/WHO 1997).

Entre os fungicidas mais utilizados tem-se, como exemplo: o oxicloreto de cobre, da primeira geração; os ditiocarbamatos, da segunda geração; e vários fungicidas sistêmicos como benomil, carbendazim, tiabendazol, pirazofós e propiconazole, da terceira geração.

O etilenobisditiocarbamato, mancozebe, está entre os 12 agrotóxicos mais vendidos no Brasil.

Os alimentos com resíduos acima dos Limites Máximos de Resíduos (LMR) estabelecidos pelos órgãos governamentais indicam que a aplicação do agrotóxico não foi realizada de acordo com as Boas Práticas Agrícolas. 
Entende-se por LMR a quantidade máxima de resíduo de um agrotóxico ou afim oficialmente aceita no alimento, em decorrência da aplicação adequada numa fase específica, desde sua produção até o consumo. Expressa-se o LMR em ppm, partes do agrotóxico, afim ou seus resíduos, por milhão de partes de alimento (ppm ou $\mathrm{mg} / \mathrm{kg}$ ) (MINISTÉRIO DA SAÚDE 2003).

Os consumidores de alimentos, se ingerirem uma dose de qualquer princípio ativo de agrotóxico acima da Ingestão Diária Aceitável (IDA), por longo prazo, estariam sob risco de apresentarem algum efeito adverso à saúde.

Nos últimos cinco anos, houve aumento do monitoramento de resíduos de agrotóxicos no Brasil. Destaca-se o Programa de Análise de Resíduos de Agrotóxicos em Alimentos (PARA) e o Programa Paulista de Análise Fiscal de Alimentos (PP) (ANVISA 2003, 2005; SÃO PAULO 2005).

Em relação a resíduos de ETU, há pesquisas na literatura intenacional, porém, no Brasil, existem poucos trabalhos em frutas, conforme mencionados no ítem 1.14.3. É importante o conhecimento dos níveis de EBDC e de ETU presentes nas frutas, para fornecer subsídios sobre a qualidade das frutas consumidas pela população e dados para avaliação de risco à saúde e ao meio ambiente.

\subsubsection{Legislação e normas referentes aos Limites Máximos de Resíduos (LMR) de agrotóxicos nos alimentos}

De maneira a controlar o uso adequado de agrotóxicos no campo e o nível de resíduos desses compostos nos alimentos, órgãos internacionais e nacionais estabelecem o Limite Máximo de Resíduo (LMR) para cada binômio agrotóxico/cultura, tomando por base os estudos de campo. Nestes estudos, os produtos formulados são aplicados numa determinada cultura de acordo com as Boas Práticas Agrícolas, e são determinados os níveis de resíduos remanescentes nos alimentos.

No Brasil, a Resolução RE 165, de 29 de agosto de 2003, da Agência Nacional de Vigilância Sanitária do Ministério da Saúde (ANVISA/MS), publicada no Diário Oficial da União de 2 de setembro de 2003, estabeleceu os respectivos LMR para cada agrotóxico/cultura (MINISTÉRIO DA SAÚDE 2003). 
Também, no âmbito internacional, cada país estabelece seus LMR durante o processo de registro do produto.

A fim de facilitar o comércio comum de produtos agrícolas, organizações como a União Européia, o Mercosul, a Comissão do Codex Alimentarius para Resíduos de Pesticidas (CCPR) da Organização das Nações Unidas para a Agricultura e Alimentação da Organização Mundial da Saúde (FAO/WHO), entre outras, têm buscado harmonizações de alguns LMR.

A CCPR, seguindo recomendações do Grupo de Peritos em Resíduos de Pesticidas (JMPR) da FAO/WHO, estabelece os LMR de acordo com as Boas Práticas Agrícolas (BPA), visando preservar a saúde humana e garantir o comércio internacional de alimentos.

\subsection{Ditiocarbamatos}

Ditiocarbamatos são compostos derivados do ácido ditiocarbâmico. São caracterizados por monoaminas secundárias que reagem com dissulfeto de carbono, obtendo-se dialquil ditiocarbamatos: dimetilditiocarbamatos (DMDC), como ferbam, ziram e tiram, e os etilenobisditiocarbamatos (EBDC), como mancozebe, manebe, zinebe e metiram. Todos os ditiocarbamatos citados, com exceção do tiram, são derivados organometálicos (WHO 1988). Nesta classe de substâncias podem ser ainda citados o monometildimetilcarbamato: metam sódico e o propilenobisditiocarbamato: propinebe.

Os ditiocarbamatos são usados há décadas como fungicidas na agricultura e também no cultivo de plantas ornamentais, de grama e no tratamento do solo. $\mathrm{Na}$ indústria, são usados como antimicrobianos em sistemas de refrigeração de água (torres e lavadores de gases), em maquinário de perfuração de petróleo e em moinhos de polpa, papel e açúcar, como aceleradores da vulcanização e antioxidantes na produção da borracha, como quelantes de metais no tratamento de efluentes e na medicina humana, por exemplo, em caso de intoxicação por níquel (WHO 1988).

Entre os fungicidas, os ditiocarbamatos são os que detêm registro para praticamente todas as frutas e hortaliças. 


\subsubsection{Dimetilditiocarbamatos}

Os dimetilditiocarbamatos são produzidos pela reação de dissulfeto de carbono $\left(\mathrm{CS}_{2}\right)$ com uma amina em condições alcalinas, podendo ocorrer, em seguida, oxidação para formar dissulfetos (por exemplo: tiram) ou precipitação, como um sal de metal pesado de composição química definida (por exemplo: ziram). Algumas características físico-químicas dos dimetilditiocarbamatos encontram-se na Tabela 1.

Tabela 1 - Características físico-químicas dos dimetilditiocarbamatos

\begin{tabular}{|c|c|c|c|}
\hline $\begin{array}{l}\text { Ditio- } \\
\text { carbamato }\end{array}$ & $\begin{array}{l}\text { Nome } \\
\text { químico }\end{array}$ & Fórmula estrutural & $\begin{array}{l}\text { (Massa molecular) } \\
\text { Solubilidade }\end{array}$ \\
\hline Ziram & $\begin{array}{l}\text { Dimetilditio- } \\
\text { carbamato de } \\
\text { zinco }\end{array}$ & $\begin{array}{c}\mathrm{S} \\
{\left[\left(\mathrm{CH}_{3}\right)_{2}-\mathrm{NH}_{2}-\mathrm{C}\right.} \\
\mathrm{C}_{\mathrm{S}-}\end{array}$ & $\begin{array}{l}(305,81) \\
65 \mathrm{mg} / \mathrm{L} \text { água/ a } 25^{\circ} \mathrm{C} \text {; relativa- } \\
\text { mente solúvel em benzeno e } \\
\text { acetona; solúvel em clorofórmio } \\
\text { e sulfeto de carbono. }\end{array}$ \\
\hline Ferbam & $\begin{array}{l}\text { Dimetilditio- } \\
\text { carbamato } \\
\text { férrico }\end{array}$ & {$\left[\begin{array}{c}\mathrm{S} \\
\left.\stackrel{\mathrm{C}}{\mathrm{C}} \mathrm{CH}_{3}\right)_{2}-\mathrm{NH}_{2}-\mathrm{Fe} \\
\mathrm{S}-\end{array}\right.$} & $\begin{array}{l}(416,51) \\
130 \mathrm{mg} / \mathrm{L} \text { /água a } 25^{\circ} \mathrm{C} \text {; solúvel } \\
\text { em acetona e clorofórmio. }\end{array}$ \\
\hline Tiram & $\begin{array}{l}\text { Bissulfeto de } \\
\text { tetrametil- } \\
\text { tiouram }\end{array}$ & 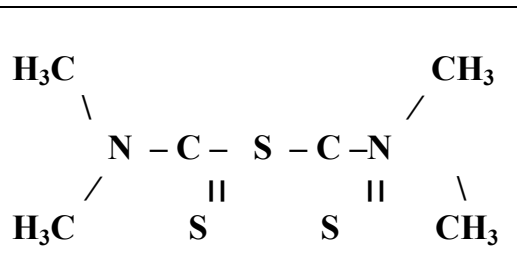 & $\begin{array}{l}(240,44) \\
30 \mathrm{mg} / \mathrm{L} \text { /água a } 25^{\circ} \mathrm{C} \text {; pouco } \\
\text { solúvel em etanol, éter etílico e } \\
\text { acetona. }\end{array}$ \\
\hline
\end{tabular}

Fonte: WHO 1988; LARINI 1999; TOMLIN 1995.

\subsubsection{Etilenobisditiocarbamatos (EBDC)}

Os EBDC são sais orgânicos de manganês, zinco ou zinco e sódio (Tabela 2). São insolúveis em água e em solventes orgânicos (MESTRES e MESTRES 1991). São produzidos pela reação de dissulfeto de carbono $\left(\mathrm{CS}_{2}\right)$ com uma amina em condições alcalinas, podendo ocorrer precipitação com sal de metal pesado de natureza polimérica e definição incompleta, especialmente na presença de alguns íons metálicos (por exemplo: mancozebe). São fungicidas usados no mundo todo. Possuem amplo espectro de ação no controle de moléstias que atacam diversos cultivos, tais como cereais, frutas e legumes. 
$\mathrm{Na}$ América Latina, mais de $50 \%$ de todos os fungicidas utilizados são do grupo dos EBDC e, no Brasil, o volume de fungicidas EBDC supera os 40\% do total utilizado no país, representando o principal produto contra fungos. Na Tabela 2 encontram-se algumas características físico-químicas dos EBDC.

Tabela 2 - Características físico-químicas dos etilenobisditiocarbamatos autorizados para uso no Brasil

\begin{tabular}{|c|c|c|c|}
\hline $\begin{array}{l}\text { Nome } \\
\text { comum }\end{array}$ & Nome químico & Fórmula estrutural & $\begin{array}{l}\text { (Massa molecular) } \\
\text { Solubilidade }\end{array}$ \\
\hline Mancozebe & $\begin{array}{l}\text { Etilenobisditio- } \\
\text { carbamato de } \\
\text { manganês e } \\
\text { zinco complexo } \\
\text { polimérico) }\end{array}$ & 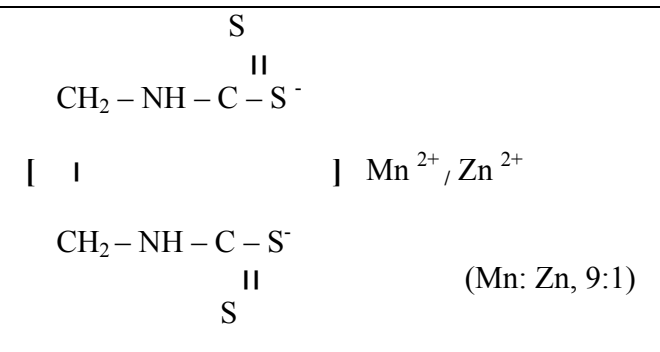 & $\begin{array}{l}\text { (Variável) } \\
\text { Insolúvel em água a } \\
25^{\circ} \mathrm{C} \text { e em solventes } \\
\text { apolares. }\end{array}$ \\
\hline Manebe & $\begin{array}{l}\text { Etilenobis- } \\
\text { ditiocarbamato } \\
\text { de manganês }\end{array}$ & 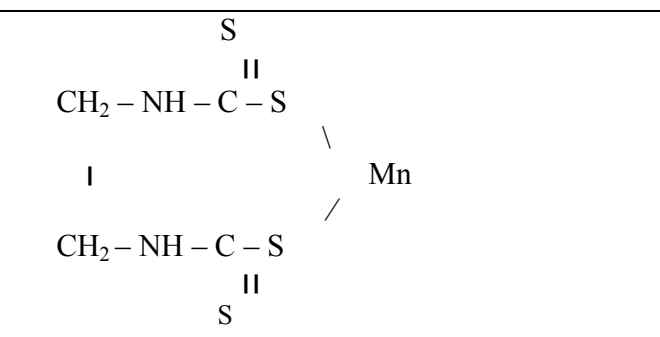 & $\begin{array}{l}(265,29) \\
\text { Insolúvel em água a } \\
25^{\circ} \mathrm{C} \text { e na maioria } \\
\text { dos solventes } \\
\text { orgânicos. }\end{array}$ \\
\hline Metiram & $\begin{array}{l}\text { Complexo de } \\
\text { amônia com } \\
\text { zinebe e polieti- } \\
\text { leno tiouram } \\
\text { dissulfeto }\end{array}$ & 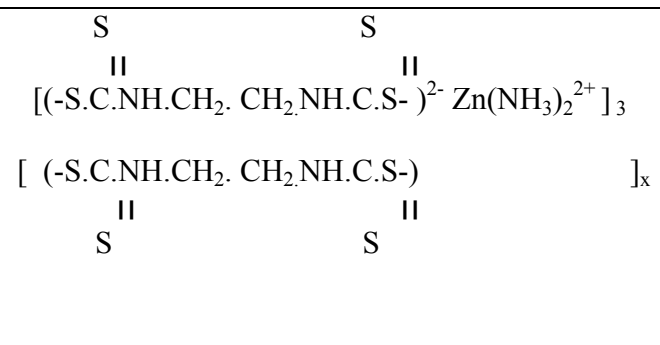 & $\begin{array}{l}\text { (Variável) } \\
\text { Insolúvel em água a } \\
25^{\circ} \mathrm{C} \text {. }\end{array}$ \\
\hline
\end{tabular}

Fonte: WHO, 1988; LARINI 1999; TOMLIN 1995.

\subsubsection{Outros ditiocarbamatos}

Ainda há o metam sódico, que é um monometilditiocarbamato, e o propinebe (Tabela 3). O propinebe é insolúvel em água e em solventes não polares, não é metabolizado a etilenotiouréia (ETU), mas sim em propilenotiouréia (PTU) (WHO 1988). 
Tabela 3 - Características físico-químicas do metam sódico e do propinebe

\begin{tabular}{|c|c|c|}
\hline $\begin{array}{l}\text { Ditiocarbamato } \\
\text { (grupo químico) }\end{array}$ & Fórmula estrutural & $\begin{array}{l}\text { (Massa molecular) } \\
\text { Solubilidade }\end{array}$ \\
\hline $\begin{array}{l}\text { Metam-sódico } \\
\text { (Monometilditiocar } \\
\text { bamato) }\end{array}$ & 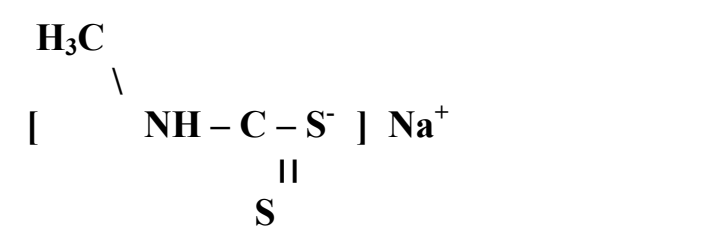 & $\begin{array}{l}(129,18) \\
722 \mathrm{mg} / \mathrm{L} / \text { água a } 20^{\circ} \mathrm{C}\end{array}$ \\
\hline $\begin{array}{l}\text { Propinebe } \\
\text { (Alquilenobisditioc } \\
\text { arbamato) }\end{array}$ & 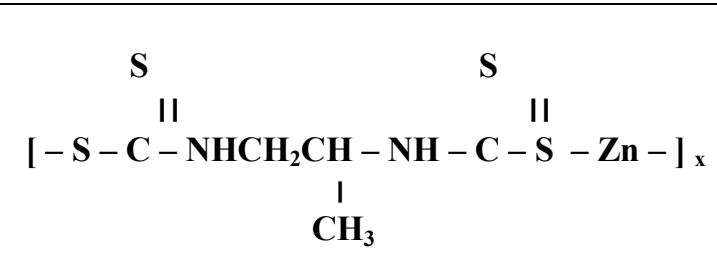 & $\begin{array}{l}(289,90) \\
\text { Insolúvel em água a } 25^{\circ} \mathrm{C}\end{array}$ \\
\hline
\end{tabular}

Fonte: WHO, 1988; LARINI 1999; TOMLIN 1995.

\subsubsection{Limites Máximos de Resíduos (LMR) de ditiocarbamatos nos alimentos}

Os LMR dos ditiocarbamatos são estabelecidos para $\mathrm{CS}_{2}(\mathrm{mg} / \mathrm{kg})$ em função do uso dos ingredientes ativos da classe dos EBDC: mancozebe, manebe, metiram, além de outros ditiocarbamatos, como o propinebe e o tiram (MINISTÉRIO DA SAÚDE 2003), conforme Tabelas 4, 5 e 6.

A Comissão do Codex Alimentarius para Resíduos de Pesticidas (CCPR) da FAO/WHO estabelece LMR para: mancozebe, manebe, metiram, zinebe, propinebe, tiram, ziram, ferbam, com valores expressos em $\mathrm{CS}_{2}$ total (Tabelas 4, 5 e 6).

Os Limites Máximos de Resíduos (LMR) permitidos pela legislação brasileira para cada ditiocarbamato/cultura e os estabelecidos pelo Codex Alimentarius encontram-se explicitados nas Tabelas 4, 5 e 6.

A legislação brasileira não estabelece Limite Máximo de Resíduo (LMR) de ETU em alimentos. 
Tabela 4 - Limites Máximos de Resíduos de ditiocarbamatos permitidos no Brasil e os estabelecidos pelo Codex Alimentarius em culturas de frutas.

\begin{tabular}{|c|c|c|c|c|}
\hline & \multicolumn{4}{|c|}{$\begin{array}{c}\text { Ditiocarbamatos } \\
\left(\mathbf{C S}_{2}\right)\end{array}$} \\
\hline & \multicolumn{2}{|c|}{$\begin{array}{c}\text { Resolução } 165 \text { ANVISA/MS* } \\
\text { BRASIL }\end{array}$} & \multicolumn{2}{|c|}{$\begin{array}{c}\text { Codex Alimentarius** } \\
\text { FAO/WHO }\end{array}$} \\
\hline $\begin{array}{l}\text { Cultura } \\
\text { (frutas) }\end{array}$ & $\begin{array}{c}\mathbf{L M R} \\
(\mathrm{mg} / \mathrm{kg})\end{array}$ & $\begin{array}{l}\text { Ingrediente } \\
\text { ativo }\end{array}$ & $\begin{array}{c}\mathbf{L M R} \\
(\mathrm{mg} / \mathrm{kg})\end{array}$ & $\begin{array}{l}\text { Ingrediente } \\
\text { ativo }\end{array}$ \\
\hline Banana & 1,0 & Mancozebe & 2,0 & Mancozebe \\
\hline Citros & 2,0 & Mancozebe & 2,0 & Mancozebe \\
\hline Maçã & 2,0 & Metiram e Mancozebe & 2,0 & Propinebe \\
\hline Mamão & 3,0 & Mancozebe & 5,0 & Mancozebe \\
\hline Manga & 1,0 & Mancozebe & 2,0 & Mancozebe \\
\hline Melancia & 0,3 & Mancozebe & 1,0 & Mancozebe e Manebe \\
\hline Melão & 1,0 & Mancozebe & 0,5 & Mancozebe \\
\hline Morango $^{a}$ & 0,2 & Metam sódico & & \\
\hline Pêra & 3,0 & Mancozebe & & \\
\hline Pêssego & 2,0 & Mancozebe & & \\
\hline Uva & 3,0 & Mancozebe & 5,0 & Propinebe \\
\hline
\end{tabular}

$\mathrm{a}=0,2 \mathrm{mg} / \mathrm{kg}$ de Metam sódico pelo Ministério da Saúde, 2003.

Fonte: * MINISTÉRIO DA SAÚDE (2003) **FAO/WHO (2007). 
Tabela 5 - Limites Máximos de Resíduos de ditiocarbamatos permitidos no Brasil e os estabelecidos pelo Codex Alimentarius em culturas de vegetais

\begin{tabular}{|c|c|c|c|c|}
\hline \multirow{3}{*}{$\begin{array}{l} \\
\\
\begin{array}{l}\text { Cultura } \\
\text { (vegetais) }\end{array}\end{array}$} & \multicolumn{4}{|c|}{$\begin{array}{c}\text { Ditiocarbamatos } \\
\left(\mathrm{CS}_{2}\right)\end{array}$} \\
\hline & \multicolumn{2}{|c|}{$\begin{array}{c}\text { Resolução } 165 \text { ANVISA/MS* } \\
\text { BRASIL }\end{array}$} & \multicolumn{2}{|c|}{$\begin{array}{l}\text { Codex Alimentarius** } \\
\text { FAO/WHO }\end{array}$} \\
\hline & $\begin{array}{c}\mathbf{L M R} \\
(\mathrm{mg} / \mathrm{kg})\end{array}$ & $\begin{array}{l}\text { Ingrediente } \\
\text { ativo }\end{array}$ & $\begin{array}{l}\mathbf{L M R} \\
(\mathrm{mg} / \mathrm{kg})\end{array}$ & Ingrediente ativo \\
\hline Alface & 6,0 & Manebe & 10,0 & $\begin{array}{c}\text { Mancozebe, Manebe e } \\
\text { Metiram }\end{array}$ \\
\hline Batata $^{b}$ & 0,3 & Propinebe & 0,2 & Mancozebe e Manebe \\
\hline Berinjela & 0,5 & Mancozebe & & \\
\hline Beterraba & 0,3 & Mancozebe & & \\
\hline Brócolis & 0,5 & Mancozebe & & \\
\hline Cenoura & 0,3 & Mancozebe & 1,0 & Mancozebe \\
\hline Couve & 1,0 & Mancozebe & & Mancozebe \\
\hline Couve-flor & 0,5 & Mancozebe & & Mancozebe e Manebe \\
\hline Milho & 0,3 & Tiram & & \\
\hline Pepino & 0,3 & Mancozebe & 2,0 & Mancozebe e Manebe \\
\hline Pimentão & 1,0 & Mancozebe & 2,0 & $\begin{array}{l}\text { Mancozebe, Manebe e } \\
\text { Propinebe }\end{array}$ \\
\hline Repolho & 1,0 & Mancozebe & 5,0 & Manebe \\
\hline Tomate & 2,0 & Mancozebe & 5,0 & Manebe \\
\hline
\end{tabular}

Fonte: * MINISTÉRIO DA SAÚDE (2003) **FAO/WHO (2007). 
Tabela 6 - Limites Máximos de Resíduos de ditiocarbamatos permitidos no Brasil e os estabelecidos pelo Codex Alimentarius em culturas de cereais e outras.

\begin{tabular}{|c|c|c|c|c|}
\hline \multirow{3}{*}{ 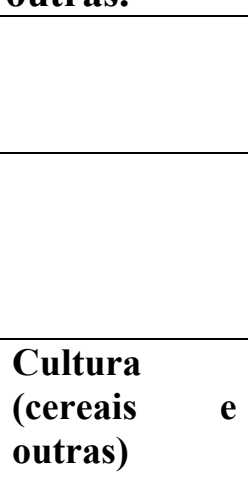 } & \multicolumn{4}{|c|}{$\begin{array}{l}\text { Ditiocarbamatos } \\
\left(\mathrm{CS}_{2}\right)\end{array}$} \\
\hline & \multicolumn{2}{|c|}{$\begin{array}{c}\text { Resolução no } 165 \text { 29/08/03* } \\
\text { ANVISA/MS } \\
\text { BRASIL }\end{array}$} & \multicolumn{2}{|c|}{$\begin{array}{c}\text { Codex Alimentarius** } \\
\text { FAO/WHO }\end{array}$} \\
\hline & $\begin{array}{c}\mathbf{L M R} \\
(\mathrm{mg} / \mathrm{kg})\end{array}$ & $\begin{array}{l}\text { Ingrediente } \\
\text { ativo }\end{array}$ & $\begin{array}{c}\mathbf{L M R} \\
(\mathrm{mg} / \mathrm{kg})\end{array}$ & $\begin{array}{c}\text { Ingrediente } \\
\text { ativo }\end{array}$ \\
\hline Abóbora & 1,0 & Mancozebe & 0,2 & Mancozebe \\
\hline Aipo & 0,5 & Manebe & & \\
\hline Algodão & 0,3 & Tiram & & \\
\hline Alho & 0,1 & Mancozebe & 0,5 & Mancozebe \\
\hline Amendoim & 0,3 & Tiram & 0,1 & Mancozebe \\
\hline Arroz & 3,0 & Mancozebe & & \\
\hline Aveia & 0,3 & Tiram & & \\
\hline Café & 0,3 & Mancozebe & & \\
\hline Cebola & 0,5 & Propinebe & 0,5 & Mancozebe \\
\hline Cevada & 1,0 & Mancozebe & 1,0 & Mancozebe \\
\hline Ervilha & 0,3 & Mancozebe e Tiram & & \\
\hline Feijão & 0,3 & Mancozebe e Tiram & & \\
\hline Feijão-vagem & 0,3 & Mancozebe & & \\
\hline Soja & 0,3 & Tiram & & \\
\hline Trigo & 1,0 & Mancozebe & 1,0 & Manebe \\
\hline
\end{tabular}

Fonte: * MINISTÉRIO DA SAÚDE (2003) **FAO/WHO (2007).

\subsection{Degradação dos etilenobisditiocarbamatos (EBDC)}

Etilenobisditiocarbamatos geralmente são instáveis em meio alcalino ou ácido, na presença de oxigênio, bem como em sistemas biológicos, e decompõem-se rapidamente em água. Em meio alcalino ou ácido, decompõem-se em dissulfeto de carbono ou sulfeto de hidrogênio. A decomposição em sulfeto de hidrogênio depende da presença do grupo N-H. A liberação do dissulfeto de carbono depende do meio onde ocorre a hidrólise. A quantidade de $\mathrm{CS}_{2}$ formada é pequena em ácido acético, e de aproximadamente $100 \%$ em ácido sulfúrico. Produtos secundários são formados pela degradação oxidativa dos EBDC (WHO 1988). 
A degradação dos EBDC pode ocorrer durante a manufatura ou o armazenamento do produto formulado, na cultura após o tratamento e, principalmente, durante o processamento do alimento.

Microorganismos rapidamente formam ETU a partir de etileno bistiouram dissulfeto (DIDT), um produto de decomposição espontânea dos EBDC. Essa conversão ocorre após adição de compostos de redução como cisteína, glutationa ou ácido ascórbico. Consiste na redução da ligação S-S do DIDT, com a subseqüente ligação com o dissulfeto de carbono para formar ETU (WHO 1988).

A decomposição metabólica dos EBDC é complexa e resulta na formação de dissulfeto de carbono $\left(\mathrm{CS}_{2}\right)$, sulfeto de hidrogênio $\left(\mathrm{H}_{2} \mathrm{~S}\right)$, etileno diamina (EDA), etileno bistiouram dissulfeto (DIDT), etileno diisocianato (EDI), etilenotiouréia (ETU), etilenouréia (EU) e 2-imidazolina (SEIDLER e col. 1970; LYMAN 1971 apud WHO 1988), conforme ilustrada na Figura 1 (WHO 1988).

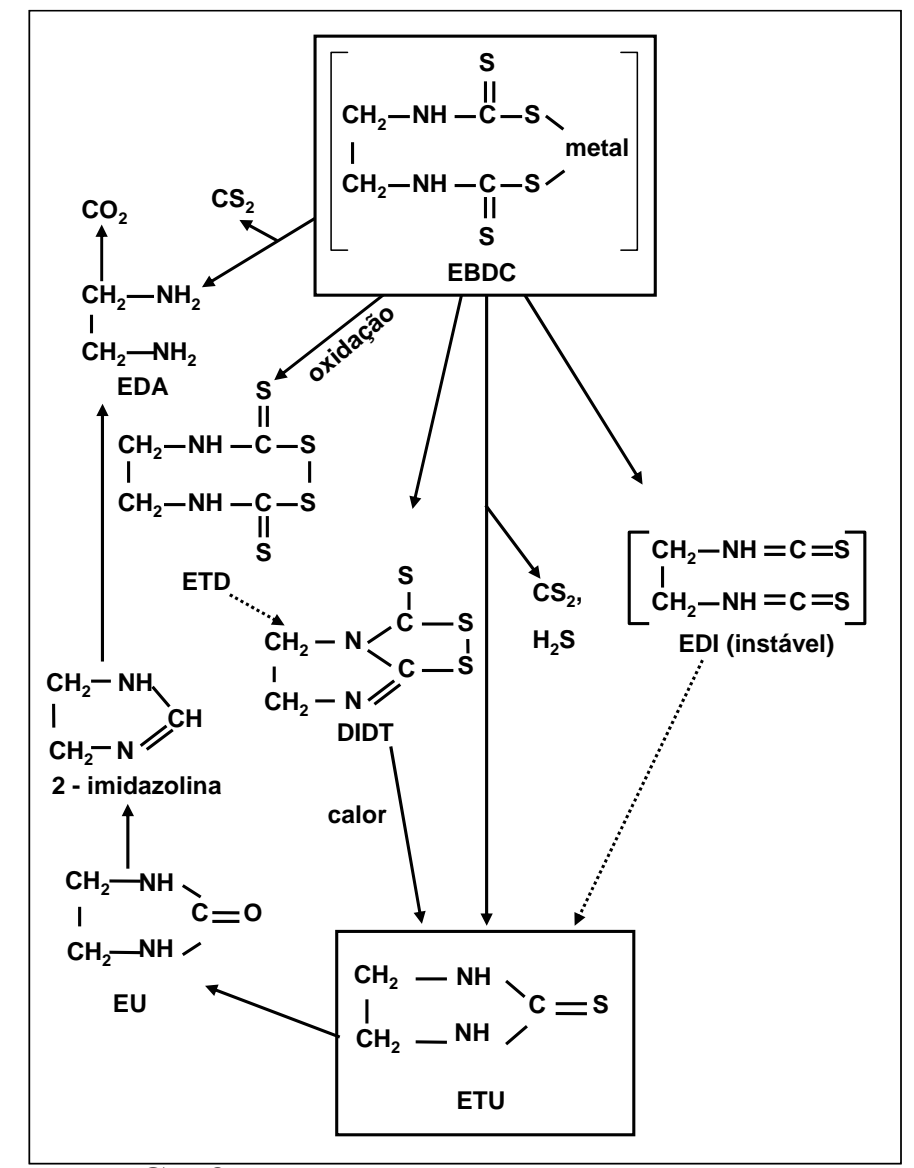

Figura 1 - Degradação dos EBDC e formação de ETU

Fonte: WHO 1988 
Estudos realizados por Nelson, em 1986, demonstraram que 23\% de 100 $\mathrm{mg} / \mathrm{kg}$ de mancozebe foram convertidos a ETU em ratos. Didonato, em 1986, concluiu que $6,4 \%$ de $100 \mathrm{mg} / \mathrm{kg}$ de mancozebe, $13,6 \%$ de $25 \mathrm{mg} / \mathrm{kg}$ de manebe, $9,5 \%$ de $5 \mathrm{mg} / \mathrm{kg}$ de metiram foram transformados em ETU em plasma de rato. Porém, estes resultados foram calculados em $\mathrm{C}^{14}$ total, sem considerar os respectivos pesos moleculares. Considerando a máxima conversão in vivo nos estudos citados (23\% de mancozebe e $13,6 \%$ de manebe) e os pesos moleculares, $8,7 \%$ de mancozebe e 5,2\% de manebe foram transformados em ETU (NELSON 1986 e DIDONATO 1986 apud MAFF 1990).

\subsection{Etilenotiouréia (ETU)}

Etilenotiouréia ou 2-imidazoledinona (ETU) tem como fórmula molecular: $\mathrm{C}_{3} \mathrm{H}_{6} \mathrm{~N}_{2} \mathrm{~S}$, massa molecular: 102,16. É uma substância formada pela degradação e/ou biotransformação dos fungicidas etilenobisditiocarbamatos (EBDC), solúvel em água, em etanol e em metanol e medianamente estável em água. Resíduos de ETU podem ser encontrados em plantas e no ambiente, seguidos do uso na agricultura de EBDC, ou em animais e no ser humano, quando expostos a esses produtos (WHO 1988).

Durante estocagem, processamento e cozimento de alimentos, a quantidade do produto principal (EBDC) decresce enquanto a quantidade de ETU aumenta.

ETU pode também ser liberada em fumaça de cigarro contendo altos resíduos de EBDC (LENTZA 1990).

\subsubsection{Formação de ETU na fabricação de EBDC e durante o armazenamento}

ETU pode ser formada durante a manufatura de EBDC. Sua degradação durante a estocagem depende do tempo, da umidade e da temperatura (MESTRES e MESTRES 1991). Foram analisadas 85 amostras de formulações comerciais e 3 $(3,5 \%)$ excederam o limite de $0,5 \%$, estabelecido pela legislação italiana para ETU (CAMONI e col. 1988). 
A importância da qualidade da formulação aplicada às culturas levou vários países a impor limites para a ETU nas formulações comerciais de EBDC. A tolerância deste contaminante nas formulações comerciais foi estabelecida pela FAO em $0,5 \%$ (FAY e col. 2007).

A ETU presente nas culturas, imediatamente após a aplicação de EBDC, é provavelmente aquela presente na formulação do fungicida. Pequenas quantidades de ETU também podem ser formadas durante a preparação da calda de aplicação e uma terceira fonte de formação de ETU pode ser devida à degradação dos EBDC depositados nas superfícies das culturas tratadas com estes fungicidas. Essas degradações são influenciadas pelas condições climáticas de temperaturas elevadas e alta umidade (FAY e col. 2007).

\subsubsection{Resíduos remanescentes de EBDC e ETU após a aplicação}

Kaushik, em 2005, analisou os resíduos remanescentes de mancozebe e ETU aplicados 4 vezes a intervalos de 15 dias na dose recomendada e no dobro desta, em bagos de uva (Vitis Vinifera L.). A meia vida de mancozebe foi de 8,1 dias na dose recomendada e 5,7 dias na dose dupla. ETU foi detectada na colheita após quatro aplicações de mancozebe na dose recomendada. Contudo, com o tratamento na dose dupla, os resíduos de ETU foram detectados após 3 aplicações de mancozebe. O intervalo proposto de pré-colheita (carência) para mancozebe foi de 12 e 17 dias, respectivamante, para as doses recomendada e dupla.

Com o objetivo de estudar a degradação de manebe e zinebe a ETU e a persistência de ETU em tomates cultivados em estufa, Knio e col., em 2000, realizaram uma pesquisa com $\mathrm{C}^{14}$ e verificaram que este decresceu de $0,08 \mathrm{mg} / \mathrm{kg}$ no $1^{\mathrm{o}}$ dia para $0,02 \mathrm{mg} / \mathrm{kg}$ e $0,05 \mathrm{mg} / \mathrm{kg}$ no $20^{\circ}$ dia, para zinebe e manebe, respectivamente. Uma acentuada redução do conteúdo de ETU foi observada nas primeiras 24 horas após o tratamento, seguida de lento declínio nos cinco dias seguintes. O conteúdo de ETU foi reduzido para aproximadamente $80 \%$ depois de 20 dias da aplicação do fungicida, e a concentração de EU, o maior produto de degradação de ETU, dobrou durante o mesmo período. 


\subsubsection{Formação de ETU no preparo e/ou industrialização de alimentos}

Muitas das frutas e hortaliças que são produzidas com utilização de EBDC, são consumidas in natura e também na forma processada e pasteurizada, como sucos, purês, polpas, massas etc. Durante esses processamentos pode ocorrer conversão do EBDC à ETU (FAY e col. 2007).

Estudo realizado por Newsome e Laver (1973) demonstrou que o cozimento de alimentos produz decomposição dos EBDC à ETU. Ankumah e Marshall (1984) concluíram que a adição de ETU é bastante estável em molho de tomate, de 76 a 91\% foram encontrados após 12 semanas, ressaltando que o tempo de espera para comercialização não garante a inexistência desse resíduo.

Em amostras fortificadas com mancozebe e cozidas na temperatura $92-97^{\circ} \mathrm{C}$ por 25 minutos houve aumento de ETU de 45,6\% em berinjela, 20\% em espinafre e 34\% em maçã (KUMAR e AGARWAL 1991).

Lentza (1990) estudou espinafre, pêra, uva, tomate e trigo, tratados com diferentes EBDC e verificaram que, após cozimento, a conversão à ETU variou de 3 a $30 \%$.

Estudo realizado por Knio e col., em 2000, com tomates fortificados com $0,006 \mathrm{mg} / \mathrm{kg}$ de ETU marcada com $\mathrm{C}^{14}$, antes do processo de formação da pasta de tomate, apresentou perda de 70\% com lavagem do tomate em água. Menores perdas de ETU ocorreram com aquecimento do suco $(6 \%)$ e estocagem da pasta de tomate por um período de 3 semanas (3\%).

$\mathrm{O}$ efeito da estocagem a $5^{\circ} \mathrm{C}$ e o processamento térmico pelo cozimento a $100^{\circ} \mathrm{C}$ e esterilização a $121^{\circ} \mathrm{C}$ por 15 minutos em tomate homogeinizado com resíduos de manebe foram investigados por Kontou e Tsipi (2004). Resíduos remanescentes de manebe e de ETU foram determinados após cada tratamento. Não foram observadas perdas significativas de manebe com a estocagem a $5^{\circ} \mathrm{C}$ por 6 semanas, levando-se em conta a variabilidade analítica. Entretanto, com o tratamento térmico resultou em degradação do manebe, com extensiva conversão à ETU. Após cozimento, somente $26 \pm 1 \%(n=8)$ do resíduo inicial de manebe remanesceram nas amostras e a conversão para ETU foi $28 \pm 1 \%(\mathrm{~mol} / \mathrm{mol})(\mathrm{n}=4)$. A esterilização 
eliminou o composto principal subindo a conversão para ETU acima de $32 \pm 1 \%$ $(\mathrm{mol} \mathrm{mol} \mathrm{-1)}(\mathrm{n}=4)$.

Em estudo realizado por Hajslová e col., em 1986, foi avaliada a conversão térmica de mancozebe para ETU durante o processamento de maçã e verificou-se que a formação de ETU foi reduzida em valores baixos de $\mathrm{pH}$. A presença de ácido ascórbico ou cisteína diminuiu signficativamente os valores produzidos de ETU após aquecimento, mas inibiu sua subseqüente decomposição. Foi constatada também que a proporção de formação de ETU não correponde ao desaparecimento relativamente rápido do composto precursor. Foram avaliados os níveis de resíduos de ETU em alimento infantil enlatado, originário de maçãs contaminadas, após 9 meses de estocagem. A redução da quantidade de ETU variou de 26 a $70 \%$.

\subsubsection{Métodos para minimizar ou remover os resíduos de EBDC e ETU}

Alguns procedimentos para remoção de resíduos de EBDC e ETU foram estudados por alguns pesquisadores.

Onley e col. (1977) descreveram que uma simples lavagem com sabão e água reduz o resíduo de EBDC em $70 \%$.

Estudos realizados por Hwang e col (2001) foram conduzidos em solução contendo mancozebe para determinar o efeito do ozônio e do ácido peróxido acético na degradação de seus resíduos, nas concentrações de 1ppm e 3 ppm e de 5ppm e 50ppm, respectivamente. Resíduos de ETU foram monitorados durante 60 minutos em $\mathrm{pH}$ 4,6, 7,0 e 10,7 e nas temperaturas de 10 e $21^{\circ} \mathrm{C}$. Verificou-se que os níveis de ETU aumentaram durante os 15 minutos de reação e depois decresceram, para todos os pH estudados. Após 15 minutos do tempo de reação com 3 ppm de ozônio, não foi detectado resíduo de ETU em nenhum dos pH estudados. Já a degradação de ETU pelo ácido peróxido acético foi mais eficiente em $\mathrm{pH} 4,6$, e não foram encontrados resíduos de ETU após 5 minutos nas amostras tratadas nos níveis de $5 \mathrm{ppm}$ e de $50 \mathrm{ppm}$. Os resultados demonstraram que o ozônio e o ácido peróxido acético são excelentes para degradação desses resíduos, dependendo do $\mathrm{pH}$ e temperatura, e indicaram o potencial de uso para a remoção de resíduos de mancozebe e ETU em frutas e produtos processados. 
Hipoclorito de cálcio $\left(\mathrm{Ca}(\mathrm{ClO})_{2}\right)$ e dióxido de cloro $\left(\mathrm{ClO}_{2}\right)$, potentes agentes oxidantes usados na indústria de alimentos, foram estudados para degradação de mancozebe e ETU em diferentes concentrações e pH. Não foram encontrados resíduos de ETU em pH 4,6 nas temperaturas de 10 e $21^{\circ} \mathrm{C}$. Os resultados demonstraram que dióxido de cloro é eficiente para baixas concentrações desses resíduos (HWANG e col. 2002).

Visando obter maior segurança alimentar de frutas e hortaliças consumidas in natura e como produtos processados, foi avaliada uma estratégia de remoção de ditiocarbamato e ETU. Utilizou-se uma unidade experimental (obtenção de polpa de maçã), na qual as frutas foram submetidas à lavagem, moagem e pasteurização. Foram comparados o sistema de lavagem padrão e esse mesmo sistema acrescido de lavagem em um tanque adicional com hipoclorito de sódio na concentração de $5 \mathrm{ppm}$, no qual as maçãs permaneceram por 10 minutos, possibilitando, desta forma, a oxidação dos ditiocarbamatos. Os dados obtidos de cada sistema foram analisados comparativamente, havendo aumento do teor de ETU após a moagem e pasteurização, indicando que resíduos remanescentes de EBDC nos frutos foram convertidos à ETU pelo aquecimento na pasteurização. Entretanto, no processo com o tanque adicional, verificou-se a redução em 50\% do teor de ETU em relação à lavagem convencional. Esse resultado é indicativo da eficácia da lavagem adicional com hipoclorito de sódio na remoção de EBDC do fruto e pode ser recomendado tanto para maçã quanto para outras frutas que utilizam ditiocarbamatos em sua cadeia produtiva, embora haja necessidade de maior número de experimentos (FAY e col. 2007).

\subsection{Toxicidade de EBDC}

O mancozebe e o manebe são classificados na classe toxicológica III como moderadamente tóxicos.

EBDC podem ser absorvidos pelo organismo através da pele, das mucosas e do trato respiratório e gastrointestinal (WHO 1988). Os ditiocarbamatos e seus produtos de metabolização foram encontrados em certos órgãos, como fígado, rins, e, especialmente, na glândula tireóide em animais de experimentação. 
Há evidência suficiente que estes três EBDC (mancozebe, manebe e metiram) podem induzir o câncer de tireóide pela formação do metabólito ETU (EPA 2001).

\subsection{Toxicidade da ETU}

ETU tem baixa toxicidade aguda, mas possui atividade carcinogênica, goiterogênica, teratogênica e mutagênica em animais de experimentação. O aspecto mais importante de sua toxicologia é a ação na glândula da tireóide, que causa hiperplasia e diminuição dos níveis de seus hormônios. O potencial teratogênico de ETU é específico para rato, enquanto que para fêmeas prenhes de camundongo, hamster, suíno e gato causa efeito limitado ou ausência de teratogenicidade, exceto em níveis muito elevados. A mutagenicidade de ETU não está claramente estabelecida, embora alguns dados existentes indiquem que de fato tem potencial mutagênico (LENTZA 1990).

Comprovadamente, a ETU tem a capacidade de induzir tumor na tiróide de roedores e no fígado de camundongo (ELIA e col. 1995; TRIVERDI e col. 1993; YOSHIDA e col. 1993 1994).

Pelos estudos de revisão, realizados pela International Agency for Research on Cancer (IARC), a ETU foi classificada no grupo 3, apresentando evidência suficiente de carcinogenicidade em estudos de animais de experimentação e evidência inadequada em seres humanos (IARC 2000).

Grisolia (1995) fez uma revisão sobre os aspectos da genotoxicidade, carcinogenicidade e teratogenicidade dos EBDC e da ETU. Os testes de carcinogênese experimental em roedores apresentaram resultados positivos para a tireóide, mas, epidemiologicamente, os dados foram inconclusivos. Tanto os fungicidas EBDC como a ETU apresentam resultados positivos de teratogênese em roedores. Quanto à mutagenicidade, observou-se uma série de resultados positivos e alguns negativos em sistemas biológicos.

Alguns estudos sobre efeitos adversos à saúde: carcinogênicos, mutagênicos, teratogênicos e outros em animais de experimentação e organismos in vitro encontram-se nas Tabelas 7, 8, 9 e 10, respectivamente. 
O tumor de tireóide em ratos tem sido relatado em vários estudos e a menor dose oral que causou este efeito, entre os estudos apresentados na Tabela 7, foi de $11,466 \mathrm{mg} / \mathrm{kg}$ em exposição por 78 semanas. Observa-se que em camundongo é necessária uma dose muito mais elevada para causar o mesmo efeito. Porém, em camundongo foi também evidenciado a presença de tumor no fígado (Tabela 7).

Segundo IARC (1987), JMPR-FAO/WHO (1994), a ETU não é um agente genotóxico para mamíferos.

Dearfield (1994), em trabalho de revisão sobre a genotoxidade da ETU, concluiu que esta é uma substância fracamente genotóxica, porém, sugeriu a necessidade de novos estudos para a elucidação deste seu potencial.

Elia e col. (1995), ao estudarem os possíveis efeitos mutagênicos da ETU, não observaram efeito genotóxico em mamíferos, o que sugere que a ETU induz tumor hepático em camundongo por outro mecanismo. Porém, o papel da ETU na indução do tumor de fígado ainda não foi elucidado.

$\mathrm{Na}$ literatura têm sido relatados vários estudos sobre efeitos mutagênicos em diversos organismos expostos à ETU, como Drosophia melanogaster, Aspergillus nidulans, Escherichia coli e alguns em mamíferos (Tabela 8). Os sistemas estudados têm sido bastante diversos. Dentre eles tem-se a conversão do gene, a recombinação miótica e o dano no DNA (Tabela 8). 
Tabela 7 - Ensaios que evidenciam efeitos carcinogênicos em animais de experimentação expostos à ETU

\begin{tabular}{|c|c|c|c|c|}
\hline Organismo & $\begin{array}{l}\text { Dose } \\
\text { oral }\end{array}$ & Duração & Efeito & Referência \\
\hline Rato & $\begin{array}{l}9,012 \\
\mathrm{mg} / \mathrm{kg}\end{array}$ & $\begin{array}{l}103 \\
\text { semanas }\end{array}$ & $\begin{array}{l}\text { Tumor na tireóide } \\
\text { - Carcinogênico * }\end{array}$ & $\begin{array}{l}\text { NATIONAL TECHNICAL } \\
\text { INFORMATION SERVICE } \\
\text { (NTIS) PB92-191618 } 1992 \\
\text { apud NIOSH/RTECS* } 2007\end{array}$ \\
\hline Rato & $\begin{array}{l}10,815 \\
\mathrm{mg} / \mathrm{kg}\end{array}$ & $\begin{array}{l}103 \\
\text { semanas }\end{array}$ & $\begin{array}{l}\text { Tumor na tireóide } \\
\text { - Carcinogênico * }\end{array}$ & $\begin{array}{l}\text { NATIONAL TECHNICAL } \\
\text { INFORMATION SERVICE } \\
\text { (NTIS) PB92-191618 } 1992 \\
\text { apud NIOSH/RTECS* } 2007\end{array}$ \\
\hline Rato & $\begin{array}{l}10,920 \\
\mathrm{mg} / \mathrm{kg}\end{array}$ & 2 anos & $\begin{array}{l}\text { Tumor na tireóide } \\
\text { - Carcinogênico * }\end{array}$ & $\begin{array}{l}\text { National Toxicology } \\
\text { Program Technical Report } \\
\text { Series (NTP-TR) NTP-TR - } \\
\text { 388, } 1992 \text { apud } \\
\text { NIOSH/RTECS* } 2007\end{array}$ \\
\hline Rato & $\begin{array}{l}11,466 \\
\mathrm{mg} / \mathrm{kg}\end{array}$ & $\begin{array}{l}78 \\
\text { semanas }\end{array}$ & $\begin{array}{l}\text { Tumor na tireóide } \\
\text { - Carcinogênico * }\end{array}$ & $\begin{array}{l}\text { Journal of the National } \\
\text { Cancer Institute (JNCI) } \\
1981 \text { apud } \\
\text { NIOSH/RTECS** } 2007\end{array}$ \\
\hline Camundongo & $\begin{array}{l}87,360 \\
\mathrm{mg} / \mathrm{kg}\end{array}$ & 2 anos & $\begin{array}{l}\text { Tumor no fígado e } \\
\text { na tireóide } \\
\text { Carcinogênico * }\end{array}$ & \begin{tabular}{lrr} 
National & \multicolumn{2}{r}{ Toxicology } \\
Program & Technical & Report \\
Series & NTP-TR) & NTP-TR- \\
388 & 1992 & apud \\
NIOSH/RTECS* & 2007
\end{tabular} \\
\hline
\end{tabular}

* classificado de acordo com os critérios da ** NIOSH /RTECS

Fonte: NIOSH /RTECS - NATIONAL INSTITUTE FOR OCCUPATIONAL SAFETY AND HEALTH /REGISTRY OF TOXIC EFFECTS OF CHEMICAL SUBSTANCES 2007. 


\section{Tabela 8 - Efeitos mutagênicos em ensaios in vitro e em animais de experimentação expostos à ETU}

\begin{tabular}{|c|c|c|c|}
\hline Organismo & Dose & Sistema Teste & Referência \\
\hline $\begin{array}{l}\text { Drosophia } \\
\text { melanogaster }\end{array}$ & $\begin{array}{l}1 \mathrm{mmol} / \mathrm{L} \\
48 \text { horas } \\
\text { oral }\end{array}$ & $\begin{array}{l}\text { Conversão gene } \\
\text { e recombinação } \\
\text { miótica }\end{array}$ & $\begin{array}{l}\text { MUTATION RESEARCH } \\
2002 \text { apud NIOSH/RTECS* } \\
2007\end{array}$ \\
\hline $\begin{array}{l}\text { Drosophia } \\
\text { melanogaster } \\
\text { múltipla }\end{array}$ & $500 \mu \mathrm{mol} / \mathrm{L}$ & Teste local & $\begin{array}{l}\text { MUTATION RESEARCH } \\
1997 \text { apud NIOSH/RTECS* } \\
2007\end{array}$ \\
\hline Camundongo & $\begin{array}{l}2 \mathrm{mg} / \mathrm{kg} \\
\text { intraperitoneal }\end{array}$ & Dano no DNA & $\begin{array}{l}\text { MUTATION RESEARCH } \\
1997 \text { apud NIOSH/RTECS* } \\
2007\end{array}$ \\
\hline $\begin{array}{l}\text { Aspergillus } \\
\text { nidulans }\end{array}$ & $39,200 \mu \mathrm{mol} / \mathrm{L}$ & $\begin{array}{l}\text { Perda e não } \\
\text { disjunção no } \\
\text { cromossomo } \\
\text { sexual }\end{array}$ & $\begin{array}{l}\text { MUTATION RESEARCH } \\
1986 \text { apud NIOSH/RTECS* } \\
2007\end{array}$ \\
\hline $\begin{array}{l}\text { Escherichia } \\
\text { coli }\end{array}$ & $\begin{array}{l}200 \mathrm{mg} / \mathrm{L} \\
\text { (ponto ativação } \\
\text { enzimática) }\end{array}$ & $\begin{array}{l}\text { Mutação nos } \\
\text { microorganismos }\end{array}$ & $\begin{array}{l}\text { PROGRESS IN } \\
\text { MUTATION RESEARCH. } \\
1981 \text { apud NIOSH/RTECS* } \\
2007\end{array}$ \\
\hline
\end{tabular}

Fonte: NIOSH /RTECS - NATIONAL INSTITUTE FOR OCCUPATIONAL SAFETY AND HEALTH /REGISTRY OF TOXIC EFFECTS OF CHEMICAL SUBSTANCES 2007.

Alguns estudos de efeitos teratogênicos em animais de experimentação têm sido relatados em diferentes doses administradas via oral, dérmica ou intraperitoneal. Observa-se, pelos estudos apresentados na Tabela 9, que uma dose de $2 \mathrm{mg} / \mathrm{kg}$ de ETU, administrada em fêmea de camundongo prenhe, bem menor do que as utilizadas em estudo para fêmea de rato prenhe, causou anormalidade no sistema esquelético-muscular dos recém-nascidos. Nota-se também que dose bem mais elevada $(2800 \mathrm{mg} / \mathrm{kg})$, administrada em pele de fêmea de rato, causou efeito também nos recém-nascidos. 
Oliveira (2005a), em sua tese de doutorado, estudou a redução da inervação motora e entérica da musculatura da pelve e das alterações sacrais em fetos de ratos com anomalia anorretal induzida, sendo 43 (controle) e 118 (portadores da anomalia), gerados por 60 fêmeas. Constatou que houve redução da inervação motora da musculatura pélvica em fetos de ratos com e sem anomalia anorretal induzida pela ETU.

Em estudos reprodutivos em ratos, o maior nível no qual não se observa efeito adverso (NOAEL) materna sistêmica para mancozebe foi de 1,5 mg/kg/dia, baseada no aumento do peso do fígado em fêmeas. Não há estudos de reprodução adequados em rato para ETU (EPA 2007b).

A EPA recomenda o uso da NOAEL materna de $30 \mathrm{mg} / \mathrm{kg} / \mathrm{dia}$ para mancozebe, baseada em estudo de toxicidade para mancozebe em coelhos, no qual os efeitos observados foram morte, ataxia e aborto (EPA 2007b).

Com relação à ETU, não existe um estudo toxicológico em coelhos adequado para avaliação. Em rato, a NOAEL oral foi $5 \mathrm{mg} / \mathrm{kg} / \mathrm{dia}$, baseada no valor encontrado no atraso da ossificação na estrutura do esqueleto fetal (EPA 2007b).

Para a avaliação de risco no desenvolvimento e toxicidade reprodutiva, a EPA recomenda usar um fator adicional de segurança (mínimo de 1.000), para proteção dos subgrupos da população (mulheres com mais de 13 anos de idade) (EPA 2007b). 
Tabela 9 - Efeitos teratogênicos em animais de experimentação associados à exposição à ETU

\begin{tabular}{|c|c|c|c|}
\hline Organismo & Dose & Sistema Teste & Referência \\
\hline Rato & $\begin{array}{l}84 \mathrm{mg} / \mathrm{kg} \text { (oral) } \\
11-14 \text { dias da } \\
\text { gestação }\end{array}$ & $\begin{array}{l}\text { Efeito no embrião ou feto. } \\
\text { Fetotoxidade, ex. atrofia } \\
\text { do feto, exceto morte. }\end{array}$ & $\begin{array}{l}\text { JOURNAL OF HEALTH } \\
\text { SCIENCE } 1999 \text { apud } \\
\text { NIOSH/RTECS* } 2007\end{array}$ \\
\hline Rato & $\begin{array}{l}2800 \mathrm{mg} / \mathrm{kg} \\
\text { (pele) } \\
7 \text { dias antes da } \\
\text { copulação (1-21 } \\
\text { dias da gestação) }\end{array}$ & $\begin{array}{l}\text { Efeito no parto, nos } \\
\text { recém-nascidos, nos } \\
\text { ainda vivos e na estatística } \\
\text { de crescimento dos recém- } \\
\text { nascidos (ex. redução do } \\
\text { ganho de peso). }\end{array}$ & $\begin{array}{l}\text { TOXICOLOGIST } 1992 \\
\text { apud NIOSH/RTECS* } 2007\end{array}$ \\
\hline Rato & $\begin{array}{l}30 \mathrm{mg} / \mathrm{kg} \text { (intra } \\
\text { peritoneal) } \\
12 \text { dias de } \\
\text { gestação }\end{array}$ & $\begin{array}{l}\text { Desenvolvimento anormal } \\
\text { específico no sistema } \\
\text { nervoso central e efeitos } \\
\text { nos recém-nascido, índice } \\
\text { de viabilidade de } \\
\text { sobrevivência. }\end{array}$ & $\begin{array}{l}\text { CONGENITAL } \\
\text { ANOMALIES } 1990 \text { apud } \\
\text { NIOSH/RTECS* } 2007\end{array}$ \\
\hline Camundongo & $\begin{array}{l}2 \mathrm{mg} / \mathrm{kg} \\
12 \text { dias da } \\
\text { gestação } \\
\text { oral }\end{array}$ & $\begin{array}{l}\text { Efeitos na fertilidade, no } \\
\text { embrião ou feto, inclusive } \\
\text { morte e anormalidades no } \\
\text { sistema esquelético- } \\
\text { muscular. }\end{array}$ & $\begin{array}{l}\text { TERATOLOGY THE } \\
\text { INTERNATIONAL } \\
\text { JOURNAL OF } \\
\text { ABNORMAL } \\
\text { DEVELOPMENT } 1983 \\
\text { apud NIOSH/RTECS* } 2007\end{array}$ \\
\hline Rato & $\begin{array}{l}60 \mathrm{mg} / \mathrm{kg} \\
13 \text { dias da } \\
\text { gestação oral }\end{array}$ & $\begin{array}{l}\text { Desenvolvimento anormal } \\
\text { crânio-facial (incluindo } \\
\text { nariz e língua) }\end{array}$ & $\begin{array}{l}\text { FOOD AND CHEMICAL } \\
\text { TOXICOLOGY } 1982 \text { apud } \\
\text { NIOSH/RTECS* } 2007\end{array}$ \\
\hline
\end{tabular}

Fonte: NIOSH /RTECS - NATIONAL INSTITUTE FOR OCCUPATIONAL SAFETY AND

HEALTH /REGISTRY OF TOXIC EFFECTS OF CHEMICAL SUBSTANCES 2007.

De uma maneira geral, nos estudos com animais de experimentação as doses são muito variadas e os efeitos observados não são os mesmos e, muitas vezes não 
permitem avaliar diferenças nos efeitos adversos encontrados em diferentes animais. Entretanto, o efeito adverso à saúde mais observado para rato e camundongo é a hipofunção da tireóide, sendo que a menor dose em rato causa o mesmo efeito (Tabela 10).

Os efeitos adversos à saúde mais freqüentemente observados têm sido os da tireóide, incluindo a alteração nos hormônios triiodotironina (T3), tiroxina (T4) e estimulador da tireóide (TSH).

A mudança dos níveis de hormônios tireoideanos em roedores, induzida pela ETU, é típica de agentes goitrogênicos, nos quais a exposição pela administração crônica interrompe a axis pituitária-tireóide, inibindo a peroxidase tireóidica, com conseqüente diminuição na circulação dos níveis de hormônio da tireóide e aumento compensatório de secreção pela pituitária do hormônio estimulador da tireóide (TSH) (ELIA e col. 1995). Contudo, pelas condições de deficiência crônica e falha no mecanismo para restabelecimento do balanço hormonal, as duas glândulas continuam a responder aos seus respectivos sinais e entram em estado de hipertrofia e hiperplasia. A pituitária continua a secretar TSH e a tireóide não pode enviar sinal de TSH interrompido por causa de sua incapacidade de secretar o hormônio da tireóide. Eventualmente, dessa interação resulta o desequilíbrio hormonal que pode induzir à neoplasia de células foliculares na glândula tireóide e, freqüentemente, neoplasia da glândula pituitária (VETORAZZI e col. 1995).

Kurttio e col (1986) estudaram os efeitos na função e morfologia da tireóide de fêmeas de rato "Wistar", após ingestão de água de consumo contendo ETU durante 28 dias, e concluíram que, na dosagem de 10,6 a 23,4mg/kg de peso corpóreo/dia, houve diminuição dos níveis dos hormônios triiodotironina (T3) e tiroxina (T4) e aumento do nível do hormônio estimulador da tireóide (TSH). A ingestão de ETU induziu as variações ultraestruturais, como dilatação do retículo endoplasmático rugoso e aumento da vacuolização nas células epiteliais de folículos da tireóide.

Amaral e col. (1985) estudaram os efeitos da ETU e da etilenouréia (EU) sobre os níveis de lipoperoxidação hepática em ratos e concluiram que a etilenotiouréia exerce efeito protetor contra a peroxidação de lipídios hepáticos, 
medido pela produção de malonildialdeído, enquanto que a EU não altera a peroxidação de lípídios em fígado.

Tabela 10 - Efeitos adversos à saúde observados em animais expostos à ETU

\begin{tabular}{|l|l|l|l|}
\hline Animal & Dose & Efeito & Referência \\
\hline Camundongo & $\begin{array}{l}277,2 \mathrm{mg} / \mathrm{kg} \\
\text { oral } \\
7 \text { dias contínuos }\end{array}$ & $\begin{array}{l}\text { Variação do peso do fígado } \\
\text { Evidência de hipofunção da } \\
\text { tireóide }\end{array}$ & $\begin{array}{l}\text { ENVIRONMENTAL } \\
\text { HEALTH } \\
\text { PERSPECTIVES 2002 } \\
\text { apud NIOSH/RTECS* } \\
2007\end{array}$ \\
\hline Rato & $\begin{array}{l}29,05 \mathrm{mg} / \mathrm{kg} \\
\text { oral } \\
7 \text { dias contínuos }\end{array}$ & $\begin{array}{l}\text { Evidência de hipofunção da } \\
\text { tireóide }\end{array}$ & $\begin{array}{l}\text { ENVIRONMENTAL } \\
\text { HEALTH } \\
\text { PERSPECTIVES 2002 } \\
\text { apud NIOSH/RTECS* } \\
\text { 2007 }\end{array}$ \\
\hline Camundongo & $\begin{array}{l}840 \mathrm{mg} / \mathrm{kg} \\
\text { oral } \\
7 \text { dias contínuos }\end{array}$ & $\begin{array}{l}\text { Variação no peso do fígado; } \\
\text { evidência de hipofunção da } \\
\text { tireóide e efeitos } \\
\text { bioquímicos: inibição de } \\
\text { enzima, ou variação no } \\
\text { sangue ou níveis nos tecidos: } \\
\text { oxidases citocromo } \\
\text { (incluindo fosfirilação } \\
\text { oxidativa) }\end{array}$ & $\begin{array}{l}\text { ENVIRONMENTAL } \\
\text { HEALTH } \\
\text { PERSPECTIVES 2002 } \\
\text { apud NIOSH/RTECS* } \\
\text { 2007. }\end{array}$ \\
\hline $\begin{array}{l}\text { Rato } \\
\text { oral } \\
29 \text { dias contínuos }\end{array}$ & $\begin{array}{l}\text { Variação na composição do } \\
\text { soro sangüíneo (ex. TP, } \\
\text { bilirubina, colesterol) }\end{array}$ & $\begin{array}{l}\text { ARCHIVES OF } \\
\text { TOXICOLOGY 1986 } \\
\text { apud NIOSH/RTECS* } \\
\text { 2007. }\end{array}$ \\
\hline
\end{tabular}

Fonte: NIOSH /RTECS - NATIONAL INSTITUTE FOR OCCUPATIONAL SAFETY AND

HEALTH /REGISTRY OF TOXIC EFFECTS OF CHEMICAL SUBSTANCES 2007. 


\subsection{Níveis de EBDC e ETU administrados em mamíferos para alguns efeitos adversos à saúde}

A Tabela 11 apresenta algumas doses utilizadas em estudos com mamíferos para alguns efeitos críticos. Foram estudados efeitos adversos na tireóde de rato, macaco e camundongoe no fígado de camundongo.

\section{Tabela 11 - Doses de EBDC e ETU para alguns efeitos críticos estudados}

\section{em mamíferos}

\begin{tabular}{|c|c|c|c|c|}
\hline Composto & Animal & Efeito Crítico & Dose $(\mathrm{mg} / \mathrm{kg} / \mathrm{dia})$ & Autor, ano \\
\hline Mancozebe & $\begin{array}{l}\text { Rato } \\
\text { (2 anos) }\end{array}$ & $\begin{array}{l}\text { Alteração dos } \\
\text { hormônios da } \\
\text { tireóide, aumento } \\
\text { de peso }\end{array}$ & NOAEL: 4,8 & $\begin{array}{l}\text { FAO/WHO } 1993 \\
\text { apud VETORAZZI } \\
\text { e col. } 1995 \text { p. } 326\end{array}$ \\
\hline Manebe & $\begin{array}{l}\text { Macaco } \\
(6 \text { meses })\end{array}$ & $\begin{array}{l}\text { Aumento de peso } \\
\text { da tireóide }\end{array}$ & NOEL*: 5 & $\begin{array}{l}\text { ROHM AND HASS } \\
\text { CO,1977;MANEB } \\
\text { TASK FORCE, } 1986 \\
\text { apud EPA 2007a. }\end{array}$ \\
\hline ETU & $\begin{array}{l}\text { Rato } \\
(1 \text { ano })\end{array}$ & $\begin{array}{l}\text { Hiperplasia da } \\
\text { tireóide }\end{array}$ & LOAEL $* * *: 0,25$ & $\begin{array}{l}\text { GRAHAN e col., } \\
1975 \text { apud (EPA } \\
2007 a)\end{array}$ \\
\hline ETU & $\begin{array}{l}\text { Camundongo } \\
(3 \text { meses })\end{array}$ & $\begin{array}{l}\text { Aumento de peso } \\
\text { da tireóide e } \\
\text { fígado }\end{array}$ & 5 & $\begin{array}{l}\text { O’ HARA, } 1985 \\
\text { apud MESTRES } \\
\text { e MESTRES, } 1991 .\end{array}$ \\
\hline ETU & $\begin{array}{l}\text { Rato } \\
\text { (3meses) }\end{array}$ & $\begin{array}{l}\text { Alteração dos } \\
\text { hormônios da } \\
\text { tireóide }\end{array}$ & NOAEL**: 6 & $\begin{array}{l}\text { GOLDMAN, } 1986 \\
\text { apud MESTRES e } \\
\text { MESTRES, } 1991 .\end{array}$ \\
\hline
\end{tabular}

* NOEL - Nível no qual não se observa o efeito - nível de exposição no qual não existe estatisticamente ou biologicamente aumento significante na freqüência ou severidade de efeito entre a população exposta e seu controle apropriado ;**NOAEL - Maior nível no qual não se observa efeito adverso - o nível mais alto de exposição no qual não existe estatisticamente ou biologicamente aumento significante na freqüência ou severidade do efeito adverso entre a população exposta e seu controle apropriado; ***LOAEL - Menor nível no qual se observa efeito adverso estatisticamente ou biologicamente significante na população exposta comparada com o seu controle apropriado.

Fonte: EPA (2007a) 


\subsection{Estudos relacionados à exposição humana a EBDC e/ou à ETU}

Durante a exposição ocupacional, tanto os EBDC como a ETU podem ser absorvidos pelos pulmões, trato gastrointestinal e pele.

Kurttio e col. (1990) avaliaram a quantidade de EBDC e ETU na formulação utilizada, suas respectivas concentrações no ambiente de trabalho durante a aplicação e os níveis de ETU na urina dos trabalhadores durante 22 dias após a exposição. A estimativa da dose inalada de ETU e EBDC durante a média de 4 horas de aplicação por período foi de 0,07 e $1,8 \mu \mathrm{g} / \mathrm{kg}$, respectivamente. A concentração de ETU na urina, 24 horas após a exposição a EBDC, foi de $0,1-2,5 \mu \mathrm{g} / \mathrm{nmol}$ de creatinina. A meia-vida estimada para eliminação de ETU através da urina foi de10 horas. Os resultados demonstraram que a determinação de ETU urinária é um indicador biológico adequado para estudo de exposição a EBDC.

Valores de referência de etilenotiouréia urinária da população geral (167 pessoas) de quatro regiões da Itália (Veneto, Lombardia, Piemonte e Trentino Alto Adige) foram comparados com os obtidos da população (97 pessoas) de Rovescala, cidade produtora de vinho a alguns quilômetros de Pavia, onde os EBDC são pulverizados por helicóptero. Foi encontrada ETU acima do limite estabelecido (1,0 $\mu \mathrm{g} / \mathrm{L})$ em $24 \%$ da população de referência e em $37 \%$ da população exposta. Os valores de ETU encontrados variaram de 0,8 a $8,3 \mu \mathrm{g} / \mathrm{L}$, para a população geral das 4 regiões, e de 0,9 a 61,4 $\mu \mathrm{g} / \mathrm{L}$, para a população de Rovescala. Fumantes e consumidores de vinho apresentaram variação estatisticamente significante dos níveis de ETU na urina (APREA e col. 1996).

Aprea e col. (1997) monitoraram a excreção urinária de ETU durante oito dias em um grupo de cinco voluntários, do sexo masculino e não fumantes, submetidos a uma dieta com alimentos também analisados, para determinação de ETU e ditiocarbamatos (como $\mathrm{CS}_{2}$ ). Os resultados das concentrações de ETU nos alimentos ingeridos pelos voluntários foram geralmente inferiores ao limite de detecção enquanto que no vinho foi de $8,8 \mu \mathrm{g} / \mathrm{L}$. Os níveis de $\mathrm{CS}_{2}$ em amostras de consumo diário alimentar variaram de 0,03 a $0,17 \mathrm{mg} / \mathrm{kg}$. A média de consumo diário de ETU no vinho foi 3,5 $\pm 0,2 \mu \mathrm{g} / \mathrm{kg}$ e o aceitável (IDA) seria $0,07 \mu \mathrm{g} / \mathrm{kg}$ peso corpóreo. Durante oito dias de estudo, uma média de 48\% de ETU ingerida no vinho foi excretada inalterada pela urina. A correlação entre a excreção urinária de ETU em 
24 horas e a ingestão diária de ETU foi 0,768 e, pelos níveis de $\mathrm{CS}_{2}$ encontrados nos alimentos, a correlação foi de 0,414 .

Aprea e col., em 1998, avaliaram a exposição à mancozebe e ETU em uma indústria de formulação, pela análise de amostras ambientais e de monitoramento biológico dos empregados. As concentrações no ar em $\mu \mathrm{g} / \mathrm{m}^{3}$ variaram de 0,2 a 1,3 para ETU e de 139,9 a 949,0 para mancozebe. A concentração urinária de ETU apresentou correlação significativa com a exposição ambiental à mancozebe $(\mathrm{r} 2=$ 0,971) e à ETU (r2=0,858). A dose potencial respiratória de ETU foi 7\% do total e a absorção estimada não excedeu a IDA para ETU ou mancozebe.

Em 1984 foi apresentado um estudo no British Journal of Industrial Medicine, com evidência de hipofunção da tireóide pela exposição ocupacional humana pela inalação de $10 \mu \mathrm{g} / \mathrm{m}^{3}$ por 10 anos intermitentes (BRITISH JOURNAL OF INDUSTRIAL MEDICINE 1984 apud NIOSH/RTECS 2007).

Os aplicadores de agrotóxicos estão sujeitos à exposição a vários princípios ativos. Os comprometimentos à saúde com o contato continuado aos agrotóxicos podem variar intensamente, dependendo de características do indivíduo, como, por exemplo, estado nutricional, idade e sexo. Sintomas como fraqueza, vômitos, náuseas, convulsões, contrações musculares, dores de cabeça, dificuldade respiratória, sangramento nasal, desmaio podem ser atribuídos à intoxicação aguda; já, lesões renais e hepáticas, efeitos neurotóxicos são geralmente atribuídos à intoxicação crônica (WILSON e OTSUKI 2004).

No Brasil, cabe ao Ministério do Trabalho e Emprego (MTE) fiscalizar a segurança e saúde no trabalho, ou seja, os ambientes e as condições de uso dos agrotóxicos. Todavia, na prática cotidiana, segundo Araújo e col. (2000), em estudo realizado em Pernambuco, foi reconhecida cobertura apenas parcial do universo de trabalhadores rurais pelo MTE, devido às limitações metodológicas, de materiais e de pessoal que culminam com baixa eficácia das ações físcalizatórias (ARAÚJO e col. 2000).

No Brasil, o estabelecimento da relação entre o surgimento de câncer entre os trabalhadores rurais e o manuseio de agrotóxicos é dificultado pelo desconhecimento da duração do tempo de exposição e dos produtos utilizados, ausência de registro de 
base populacional rural nacional e situações outras, como as migrações e exposições ambientais ao sol e à fumaça de queimadas (STOPELLI 2005).

Um aspecto relevante no trabalho rural brasileiro diz respeito à participação de crianças e adolescentes nas atividades agropecuárias. O Censo Agropecuário (1996) constatou a existência de 2.435.678 trabalhadores menores de 14 anos de idade atuando neste setor, ou seja, 18,6\% da população trabalhadora rural. Essa faixa da população é especialmente afetada pelo trabalho precoce, tanto pelos aspectos técnicos dos processos de trabalho (exposição aos agrotóxicos, às radiações solares, ao ruído, à vibração etc.), como também aqueles ligados à organização do trabalho (jornada, ritmo, conteúdo das tarefas etc.). Além disso, é preciso considerar o comprometimento do processo de socialização infantil e da escolarização (SILVA e col. 2005).

Os EBDC raramente causam reações de toxicidade aguda, mas têm severo efeito tóxico após longo prazo. Doze casos reportados pelo Bordeaux Anti-Poison Center no período de 10 anos exibiram sintomas neurológicos de severidade variável. Casos de intoxicação aguda, reportados na literatura, têm envolvido vários sinais neurológicos, incluindo dor de cabeça, vertigem e confusão, além de alguns casos de ataques, todos rapidamente reversíveis. Exposição a longo prazo tem sido associada com parkinsonismo e estudos epidemiológicos têm demonstrado aumento de risco de deteriorização neurocognitiva associada com exposição aos agrotóxicos em geral e a EBDC, especificamente. Exposição acidental ou ocupacional a EBDC e sua conseqüência após longo prazo requerem estudos adequados com relação ao mecanismo, epidemiologia e prevenção (DEBBARH 2002).

\subsection{Prováveis riscos ao meio ambiente}

A erosão do solo e as águas de enxurradas transferem resíduos de agrotóxicos de áreas tratadas para áreas não tratadas e para rios e lagos. Entre outras causas, concorrem para isso, o descarte de embalagens vazias próximas às lavouras, a aplicação de agrotóxicos a menos de $30 \mathrm{~m}$ dos cursos de água, além da lavagem de equipamentos junto à lavoura. Do total dos agricultores e trabalhadores investigados por Freitas e col. (1994), em Teresópolis-RJ, 36,6\% aplicam agrotóxicos a menos de $30 \mathrm{~m}$ das residências e $34,2 \%$ aplicam esses produtos a menos de $30 \mathrm{~m}$ de corpos de 
água, 62,2\% lavam os equipamentos na lavoura e 79,3\% descartam as águas de lavagens na lavoura, $56,1 \%$ enterram as embalagens vazias e $36,6 \%$ as queimam.

\section{- Descarte das Embalagens de Agrotóxicos Vazias}

Praticamente todos os agrotóxicos são capazes de contaminar rios e lagos com graves impactos ambientais; alguns efluentes, entretanto, são fortes contaminantes do lençol subterrâneo d'água, ampliando o espectro de contaminação, via ingestão de água contaminada (EPA 1992).

O abandono das embalagens, quase sempre com restos dos agrotóxicos, é um fator agravante do problema da contaminação ambiental, o qual, se não pode ser totalmente evitado, é passível de ser minimizado.

Nos Estados Unidos da América (USA) e no Japão, a característica poluidora das embalagens vazias já vem sendo tratada há várias décadas, mediante leis e normas sobre o assunto que obrigam ou induzem as entidades que atuam no meio rural, bem como os fabricantes, a procurarem soluções de modo a reduzir ao máximo os danos diretos ao ser humano e ao meio ambiente.

Pela legislação brasileira é obrigatória realizar a tríplice lavagem nas embalagens vazias de agrotóxicos antes do descarte, após a utilização dos produtos e, após devem ser destinadas a uma central de recolhimento para reciclagem, e as embalagens com restos de produtos químicos e prazos de validade vencidos devem ser devolvidas pelo produtor, no prazo de até um ano após a compra, aos estabelecimentos onde os produtos foram adquiridos, a quem cabe as providências. $\mathrm{O}$ agricultor que não devolver as embalagens ou não prepará-las adequadamente poderá ser multado, além de ser enquadrado na Lei de Crimes Ambientais.

A informações sobre o uso correto e seguro dos agroquímicos é assunto regulamentado pela Lei federal no 7.802, de 11 de julho de 1989 e Decreto $n^{\circ} 4.074$, de 4 de janeiro de 2002, e dispõem sobre a pesquisa, a experimentação, a produção, a embalagem e rotulagem, o transporte, o armazenamento, a comercialização, a propaganda comercial, a utilização, a importação, a exportação, o destino final dos resíduos e embalagens, o registro, a classificação, o controle, a inspeção e a fiscalização de agrotóxicos, seus componentes e afins, e estabelece as empresas produtoras e comercializadoras de agrotóxicos, seus componentes e afins, devem 
implementar com o Poder Público, programas educativos e mecanismos de controle e estímulo à devolução das embalagens vazias por parte dos usuários; e também determina penalidade para os que descumprirem as exigências estabelecidas (BRASIL 2003).

No Estado de São Paulo, desde 1993, há projetos sobre a destinação das embalagens vazias com a participação de todas as áreas diretamente afetadas, desde o fabricante de agrotóxicos até as indústrias de reciclagem, passando por órgãos técnicos ligados à produção agrícola e ao meio ambiente.

\subsubsection{Degradação de ETU no meio ambiente}

ETU é uma substância razoavelmente estável em relação a reações hidrolíticas, mas é facilmente oxidada a etilenouréia (EU). A oxidação para EU ocorre primordialmente em sistemas biológicos e por reação fotolítica, especialmente na presença de fotossensibilizadores. De acordo com Ross e Grosby (1973), a ETU demonstrou ser estável à luz solar em solução aquosa (0,5-50 ppm), mas é rapidamente fotoxidada em presença de oxigênio dissolvido e acetona ou riboflavina. Eles concluíram que fotossensibilizadores naturais podem representar uma importante parcela na transformação de ETU no meio ambiente.

Após irradiação ultravioleta de ETU em sílica gel, Cruickshank e Jarrow (1973) encontraram nove produtos de reações secundárias. 2-imidazolidinona foi identificado como o principal produto de degradação e, em menores quantidades, o composto denominado como "base de Jaffe" (Figura 2). Ross e Crosby (1973) relataram outros produtos de reação secundária de fotooxidação de ETU, como 2imidazolina e glicina (WHO1988).

A mobilidade de EBDC no solo varia consideravelmente, dependendo da solubilidade de cada princípio ativo em água e do tipo de solo. Segundo Lyman e Lancoste (1974), citados por ARAÚJO (1998 p. 9), a meia-vida, no solo, de mancozebe nas concentrações de $20 \mathrm{mg} / \mathrm{kg}$ e $10 \mathrm{mg} / \mathrm{kg}$ foram, respectivamente, 50 e 90 dias.

Johannesen e col. (1996) estudaram a degradação $0,07 \mathrm{mg} / \mathrm{kg}$ de ETU marcada com $\mathrm{C}^{14}$ em superfície e subsuperfície de solo de areia grossa. A degradação 
de ETU foi rápida na superfície e lenta na subsuperfície, o que implica em risco de contaminação das águas subterrâneas.

ETU, absorvida pelas raízes das plantas, é translocada e metabolizada, formando etilenouréia (EU) e derivados como imadazole, diisocianatos, diaminas, dissulfetos e outros metabólitos ainda não conhecidos.

ETU é rapidamente fotooxidada a EU na presença de fotossensibilizadores, como acetona e riboflavina. Etilenouréia (EU) é considerada mais estável que ETU e é o maior produto de degradação de ETU. Pode também ser oxidada fotoquimicamente, na presença de catalisador, resultando glicina e dióxido de carbono, ou microbiologicamente em solo, resultando em $\mathrm{CO}_{2}$.

A distribuição de ETU no organismo de animais de experimentação é bastante uniforme, com exceção da relativa acumulação na tiróide e no fígado (WHO 1988; NEBBIA e col 1991).

Estudos com administração de mancozebe em animais de experimentação revelaram que a maior parte da dose ingerida é eliminada inalterada pelas fezes e $15,5 \%$ é biotransformada e eliminada na urina na forma de ETU e Nacetilenodiamina. Em virtude da biotransformação dos EBDC no organismo, a ETU urinária tem sido mencionada como indicador da exposição de seres humanos a essa classe de fungicidas (KURTTIO e col. 1990; CANOSSA e col. 1993).

Os principais produtos de degradação e/ou biotransformação de ETU ocorrem por fotodecomposição ou oxidação química em plantas, animais e solo. Por fotodecomposição há formação de etilenouréia (EU), 2-imidazolina, hidantoína, glicina e "base de Jaffe" e por oxidação química EU, $\mathrm{CO}_{2}$ e outros metabólitos. Por biotransfomação há uréia, etilenodiamina (EDA), ácido oxálico, entre outros (Figura 2).

A Figura 2 apresenta produtos de reações de ETU em animais, nas plantas e no solo. 


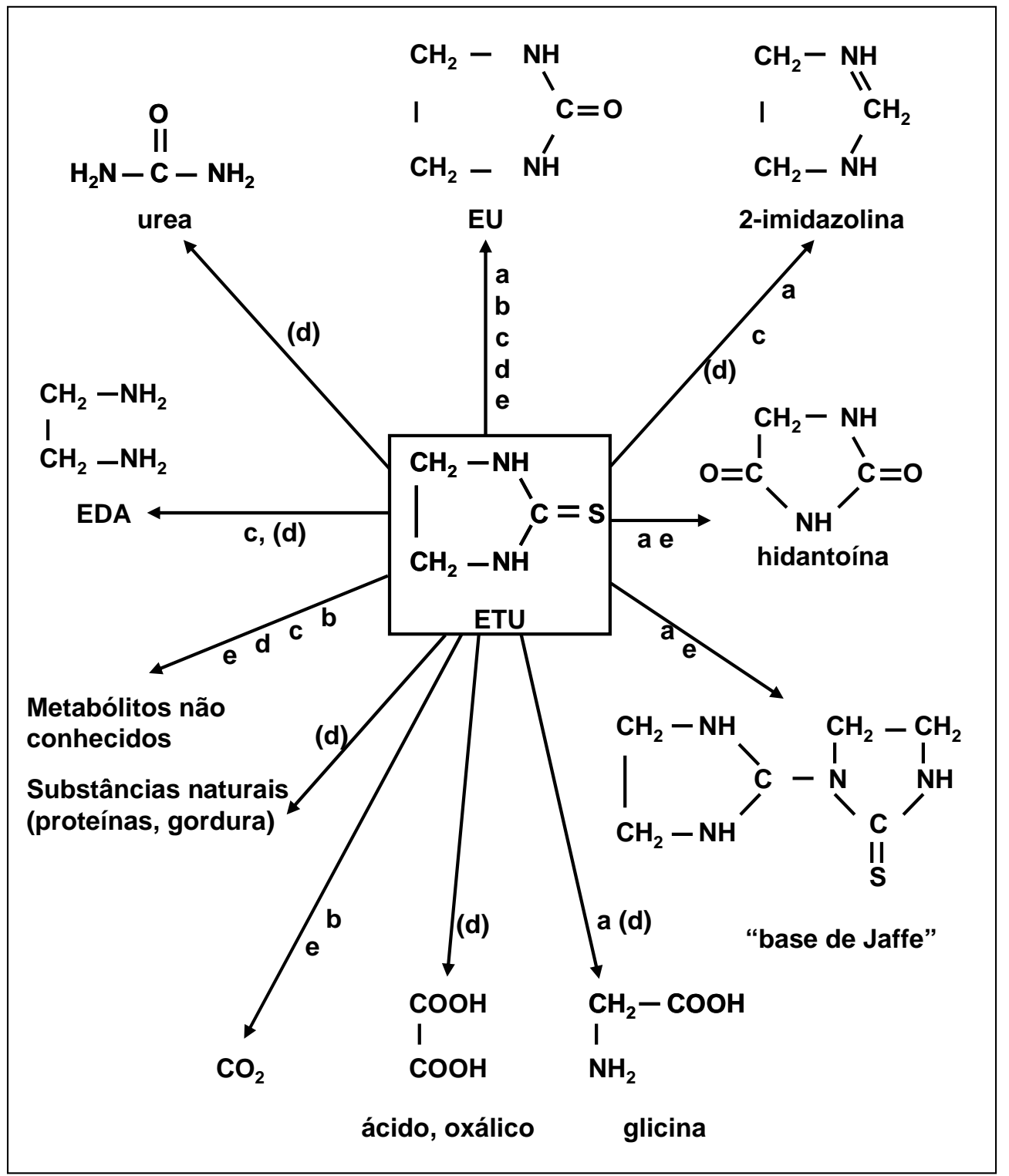

Obs: $\mathbf{a}=$ fotodecomposição; $\mathbf{b}=$ oxidação química; $\mathbf{c}=$ plantas; $\mathbf{d}=$ animais; $\mathbf{e}=$ solo

Fonte: WHO1988, com modificação.

Figura 2 - Produtos de reações de ETU em sistemas biológicos e não biológicos.

\subsubsection{Estudos de toxicidade de EBDC e ETU no ambiente}

A toxicidade aguda de EBDC é alta para algumas espécies de peixe, crustáceos, algas e bactérias. Os EBDC (mancozebe e manebe) estão classificados em relação ao risco de periculosidade ambiental como classificação ambiental II, considerados como produtos perigosos. 
Pesquisas demonstram que os microorganismos do solo são capazes de metabolizar os ditiocarbamatos. Os produtos formados podem afetar atividades enzimáticas, respiração e nitrificação em níveis de dose da ordem de $10 \mathrm{mg} / \mathrm{kg}$ ou mais em solo seco.

Conforme pode-se observar na Tabela 12, para algumas espécies de peixes, crustáceos e algas, os etilenobisditiocarbamatos (mancozebe, manebe e zinebe) são mais tóxicos do que a ETU. Para mancozebe, por exemplo, a concentração letal $\left(\mathrm{CL}_{50}\right)$ para peixe foi de $2,6 \mathrm{mg} / \mathrm{L}$ e para ETU foi de $7.500 \mathrm{mg} / \mathrm{L}$ (VAN LEEUWEN 1985a, 1985b; WHO 1988).

Tabela 12 - Estudos de toxicidade de etilenobisditiocarbamatos e de ETU e EU em peixe, crustáceos, algas e bactérias.

\begin{tabular}{|c|c|c|c|c|c|}
\hline Composto & Peixe & crustáceo & & Igas & bactérias \\
\hline & $\begin{array}{c}\text { Poecilia } \\
\text { reticulata } \\
\text { CL50 - }_{5} \\
96 \mathrm{~h} \\
(\mathrm{mg} / \mathrm{L})\end{array}$ & $\begin{array}{c}\text { Daphnia } \\
\text { magna } \\
\text { CL50 - }_{5} \\
48 \mathrm{~h} \\
(\mathrm{mg} / \mathrm{L})\end{array}$ & $\begin{array}{c}\text { Chorella } \\
\text { pyremoidosa } \\
\text { CE }_{50}- \\
96 \mathrm{~h} \\
(\mathrm{mg} / \mathrm{L})\end{array}$ & $\begin{array}{c}\text { Phytobacterium } \\
\text { phosphoreum } \\
\text { CE }_{50^{-}} \\
15 \mathrm{~min} . \\
(\mathrm{mg} / \mathrm{L})\end{array}$ & $\begin{array}{c}\text { Nitrosomonas } \\
\text { e Nitrobacter } \\
\text { CMI - } \\
\text { 3h }(\mathrm{mg} / \mathrm{L})\end{array}$ \\
\hline Mancozebe & 2,6 & 1,3 & 1,1 & 0,08 & 32 \\
\hline Manebe & 3,7 & 1,0 & 3,2 & 1,2 & 56 \\
\hline Zinebe & 7,2 & 0,97 & 1,8 & 6,2 & 18 \\
\hline ETU & 7.500 & 26,4 & 6.600 & 2.100 & 1 \\
\hline EU & 13.000 & 5.600 & 16.000 & 3.300 & 1.000 \\
\hline
\end{tabular}

Fonte: VAN LEEUWEN (1985a , 1985b); WHO (1988), com modificação.

$\mathrm{CL}=$ Concentração Letal; $\mathrm{CE}=$ Concentração efetiva (de exposição)

Os resultados de estudos de toxicidade por via oral com mancozebe revelaram que patos selvagens e marrecos japoneses apresentaram $\mathrm{DL}_{50}$ superiores a 6.400 e $3.200 \mathrm{mg} / \mathrm{kg}$, respectivamente. A concentração letal $\left(\mathrm{CL}_{50}\right)$ avaliada por 48 horas em peixes variou de 4,0 a 9,0 mg/L, dependendo da espécie estudada. Em abelhas, a CL $\mathrm{L}_{50}$ (48h) foi de 0,19 mg/abelha (TOMLIN 1995). 


\subsubsection{Estudos de ETU em amostras ambientais}

Alguns pesquisadores têm demonstrado preocupação com a possibilidade de ocorrência de ETU em água subterrânea, em rios, água de consumo humano, principalmente em áreas agrícolas onde os EBDC são utilizados, devido à relativa estabilidade e alta polaridade da ETU (HOGENDOORN e col 1991; VAN DER POLL e col 1993). A ETU já foi encontrada em água de poço após seis meses da última aplicação de mancozebe (NEIL e WILLIAMS 1990).

Calumpang e col. (1993), com o objetivo de avaliar o potencial de contaminação de lençóis freáticos, estudaram o deslocamento de mancozebe e de seus produtos de degradação no solo. Concluíram que o mancozebe, se aplicado dentro das Boas Práticas Agrícolas (BPA), não contamina águas subterrâneas com resíduos remanescentes de mancozebe ou de ETU. Porém, a degradação dos EBDC depende das condições de aplicação, descarte de embalangens vazias, condições físico-químicas e de microorganismos presentes no solo, entre outras.

Frakes (1988), baseado em efeitos adversos à saúde derivados de estudos experimentais em animais, como alterações na função da tireóide, sugere o limite de $3 \mu \mathrm{g} / \mathrm{L}(\mathrm{ppb})$ de ETU para água de consumo.

\subsubsection{Doses de referência de EBDC e ETU}

\section{- Ingestão Diária Aceitável (IDA)}

A Ingestão Diária Aceitável para os EBDC (mancozebe, manebe, metiram e zinebe) estabelecida pelo MINISTÉRIO DA SAÚDE, 2003, é de 30 $\mu \mathrm{g} / \mathrm{kg} \mathrm{pc} / \mathrm{dia}$ de $\mathrm{CS}_{2}$ e a de ETU é de $2 \mu \mathrm{g} / \mathrm{kg}$ pc /dia, estabelecida pelo Joint Meeting of the FAO Panel of Experts on Pesticide Residues in Food (JMPR), grupo assessor do Codex Alimentarius (FAO/WHO 1994).

\section{- Dose oral crônica de efeito não carcinogênico para ETU}

Baseada no valor de LOAEL mais baixo (GRAHAN e col. 1975 apud EPA 2007a), obtido pelo estudo de aumento de incidência de hiperplasia da tireóide, a EPA propõe uma dose oral crônica de efeito não carcinogênico para ETU de 0,08 $\mu \mathrm{g} / \mathrm{kg} / \mathrm{dia}$, tendo sido utilizado um fator de incerteza de 100 , por conta da diferença inter e intra espécies, um fator de 3 usado pelo limitado conhecimento do efeito 
toxicológico, por existirem muitos dados diferentes. Além disso, um adicional fator de 10 foi usado pela referência ter sido a LOAEL ao invés da NOAEL, totalizando um fator de 3.000 (EPA 2007a).

A EPA tem avaliado dados de toxicidade e considerado sua validadade, inconclusão e confiabilidade, bem como relação dos resultados dos estudos com o risco humano, e considerado a avaliação da informação em relação à variabilidade de sensibilidade dos maiores subgrupos identificáveis de consumidores, incluindo bebês e crianças (EPA 2007b).

Tabela 13 - Doses de referência de ETU

\begin{tabular}{|c|c|c|c|c|c|}
\hline População & $\begin{array}{l}\text { Doses de } \\
\text { Referência }\end{array}$ & $\begin{array}{l}\text { Valores } \\
\text { em } \\
\mu \mathrm{g} / \mathrm{kg} / \text { dia }\end{array}$ & Estudo & $\begin{array}{l}\text { Efeito } \\
\text { observado }\end{array}$ & Referência \\
\hline $\begin{array}{l}\text { População, } \\
\text { incluindo } \\
\text { subgrupos } \\
\text { sensíveis }\end{array}$ & $\begin{array}{l}\text { Oral crônica } \\
\text { de efeito não } \\
\text { carcinogênico }\end{array}$ & 0,08 & $\begin{array}{l}\text { Rato (1 } \\
\text { ano) } \\
\text { LOAEL: } \\
0,25 \\
(5 \mathrm{ppm} \\
\text { oral) }\end{array}$ & $\begin{array}{l}\text { Aumento } \\
\text { da } \\
\text { incidência } \\
\text { de } \\
\text { hiperplasia } \\
\text { da tireóide }\end{array}$ & $\begin{array}{lr}\text { GRAHAN } \quad \mathrm{e} \\
\text { col. } & 1975 \\
\text { apud } & \text { EPA } \\
2007 \mathrm{a} & \end{array}$ \\
\hline $\begin{array}{l}\text { População } \\
\text { em geral }\end{array}$ & $\begin{array}{l}\text { Ingestão } \\
\text { Diária } \\
\text { Aceitável }\end{array}$ & 2 & $\begin{array}{l}\text { Rato (1 } \\
\text { ano) } \\
\text { LOAEL: } \\
0,25 \\
(5 \mathrm{ppm} \\
\text { oral) }\end{array}$ & $\begin{array}{l}\text { Aumento } \\
\text { da } \\
\text { incidência } \\
\text { de } \\
\text { hiperplasia } \\
\text { da tireóide }\end{array}$ & $\begin{array}{l}\text { Codex } \\
\text { Alimentarius } \\
\text { (FAO/WHO } \\
\text { 1994) }\end{array}$ \\
\hline
\end{tabular}

Fonte: EPA 2007a; FAO/WHO 1994.

\subsubsection{Risco pela exposição combinada a substâncias químicas}

A maioria dos estudos não considera a interação que os diversos compostos químicos podem estabelecer entre si e nos sistemas biológicos orgânicos. 
Este é um aspecto extremamente importante em relação à análise dos riscos e danos à saúde da população exposta e ao meio ambiente, tendo em vista que são muitos os agrotóxicos utilizados, além de ocorrerem misturas de produtos no campo e também porque várias formulações de agrotóxicos se apresentam na forma de misturas.

A exposição combinada a substâncias químicas pode causar três tipos de efeitos sobre a saúde humana: independentes, sinérgicos (aditivos ou potencializados) e antagônicos. Alguns trabalhos demonstram que a resposta do organismo humano diante das exposições combinadas pode ser influenciada por algumas características pessoais, tais como tabagismo, alcoolismo e estado nutricional (SILVA e col 2005).

A Portaria 777, de 28 de abril de 2004, do Ministério da Saúde, define, entre outros pontos, que as intoxicações exógenas, dentre elas aquelas causadas por agrotóxicos, são de notificação compulsória no Brasil. Esta obrigatoriedade de notificação em todos os níveis de atenção à saúde do SUS pode ampliar a cobertura de notificação, com conseqüente melhoria na identificação dos agravos à saúde e nos estudos e pesquisas.

\subsubsection{Risco pela exposição crônica agregada à ETU}

A EPA considera como risco para a saúde humana a exposição crônica agregada. Portanto, deve-se considerar o potencial pela exposição ao mancozebe e à ETU em água para consumo humano, a exposição pela dieta alimentar e a exposição residencial ou ambiental. A exposição agregada deve levar em conta o background do nível encontrado em alimentos da dieta alimentar, em água de consumo e no meio ambiente e não deve exceder 100\% da dose de referência - RfD (EPA 2007b).

Resíduos de ETU são estabelecidos em $50 \mu \mathrm{g} / \mathrm{kg}(\mathrm{ppb})$ para alimentos pela União Européia (FAY e col. 2007).

A EPA tem considerado o risco carcinogênico de $1 \mu \mathrm{g} / \mathrm{L}(\mathrm{ppb})$ para ETU em água de consumo, sendo que o risco agregado estimado de ETU não deve exceder este nível (1ppb) (EPA 2007b). 
Estabeleceu-se na União Européia o valor de $0,1 \mu \mathrm{g} / \mathrm{L}$ como concentração máxima permitida de qualquer agrotóxico em águas destinadas ao consumo humano independente de sua toxicidade (VEIGA 2006).

A Comissão do International Union of Pure and Applied Chemistry (IUPAC) recomenda que este cálculo deva seguir o sistema da OMS, ou seja, reservar de 1 a 10\% da IDA para a presença de resíduos de agrotóxicos na água ingerida (HAMILTON 2003 apud PEREIRA 2005).

A legislação brasileira não prevê resíduos de ditiocarbamatos, mancozebe ou ETU em água de consumo.

O risco de câncer pelo mancozebe é baseado na ETU. Mancozebe tem sido classificado no Grupo B2, provavelmente carcinogênico para humanos, pelo Cancer Peer Review Committee and Science Advisory Panel, baseado na evidência de tumor da tireóide em camundongo (EPA 2007b).

Stoppelli (2005), levantando dados sobre o uso de agrotóxicos na região central paulista e mapeando casos de câncer entre trabalhadores rurais do município de Bariri, segunda base hospitalar de referência no país, encontrou um Risco Relativo de 1.6, indicando quase duas vezes mais chances de desenvolver câncer em trabalhadores rurais quando comparado com outras profissões locais, para o grupo e período estudados.

\subsubsection{Risco pela exposição aguda à ETU}

O cálculo do risco da ingestão de resíduos de agrotóxicos com potencial de risco agudo elevado é muito importante, principalmente, para a proteção da saúde de crianças e bebês.

A avaliação do risco de exposição aguda é feita pelo uso do agrotóxico no alimento quando estudos toxicológicos indicam a possibilidade de um efeito ocorrer como resultado de 1 dia de exposição. Para avaliação de risco agudo pela ingestão de ETU, a EPA recomenda o uso da NOAEL oral de $5 \mathrm{mg} / \mathrm{kg} / \mathrm{dia}$, obtido de estudo toxicológico realizado em rato, no qual o efeito observado foi o aumento de ossificação no esqueleto do feto (EPA 2007b). Este estudo também é usado nos Estados Unidas da América para avaliação de risco agudo para bebês e crianças (EPA 2007b). 


\subsection{Frutas}

\subsubsection{Mercado mundial de frutas}

Em 2004, a produção mundial de frutas foi de 675,1 milhões de toneladas. A China ocupou o primeiro lugar no "ranking", com 161 milhões de toneladas, seguida da Índia com 58 milhões de toneladas. O Brasil ficou com a terceira colocação, produzindo 39 milhões de toneladas, representada principalmente pelas culturas de banana, laranja, abacaxi, mamão, castanha-de-caju e castanha-do-Pará. O mercado interno absorveu 21 milhões de toneladas/ano e o excedente exportável foi cerca de 17 milhões de toneladas no ano de 2004 (MAPA 2007e).

Como pode-se observar na Figura 3, os maiores produtores mundiais de maçã são: China (37\%), Turquia (4\%), Itália (3\%) e Brasil (2\%); de mamão são: Brasil (25\%), México (15\%), Índia (11\%) e Indonésia (10\%) e de morango: EUA (27\%), Espanha (9\%), Itália e México (5\%) (OLIVEIRA 2005b). No período de 2002 a 2006, as exportações de produtos agropecuários brasileiros tiveram aumento de $99 \%$, saltando de US\$ 24,8 bilhões para US\$ 49,4 bilhões, segundo dados do MAPA. As frutas, incluindo nozes e castanhas, ficaram no $5^{\circ}$ lugar, com aumento de $91 \%$ nas vendas, expandindo de US\$ 400 milhões para US\$ 702 milhões (MAPA 2007b).

Países da Comunidade Européia são os maiores importadores de frutas frescas brasileiras, representando 63\% do total das exportações (SEAGRI 2005).

Foram exportadas 153.043 toneladas de maçãs frescas, correspondentes a 72.550.000 dólares, para Holanda, Reino Unido, Alemanha, Suécia, e 2 toneladas de maçãs secas, equivalentes a 6.000 dólares, para o Chile, e importadas 42.478 toneladas (17.641.000 dólares) de maçãs frescas da Argentina, Chile, Uruguai e França e 28 toneladas (86.000 dólares) de maçãs secas da Argentina, em 2004 (MAPA 2007d).

O crescimento da cadeia produtiva de frutas no mercado mundial foi impulsionado pelo programa de Produção Integrada de Frutas (PIF), com redução dos índices de aplicação de substâncias agroquímicas nos pomares, oferecendo aos consumidores frutas mais saudáveis e seguras, além de contribuir para a preservação ambiental e para a saúde do trabalhor (MAPA 2007b). 


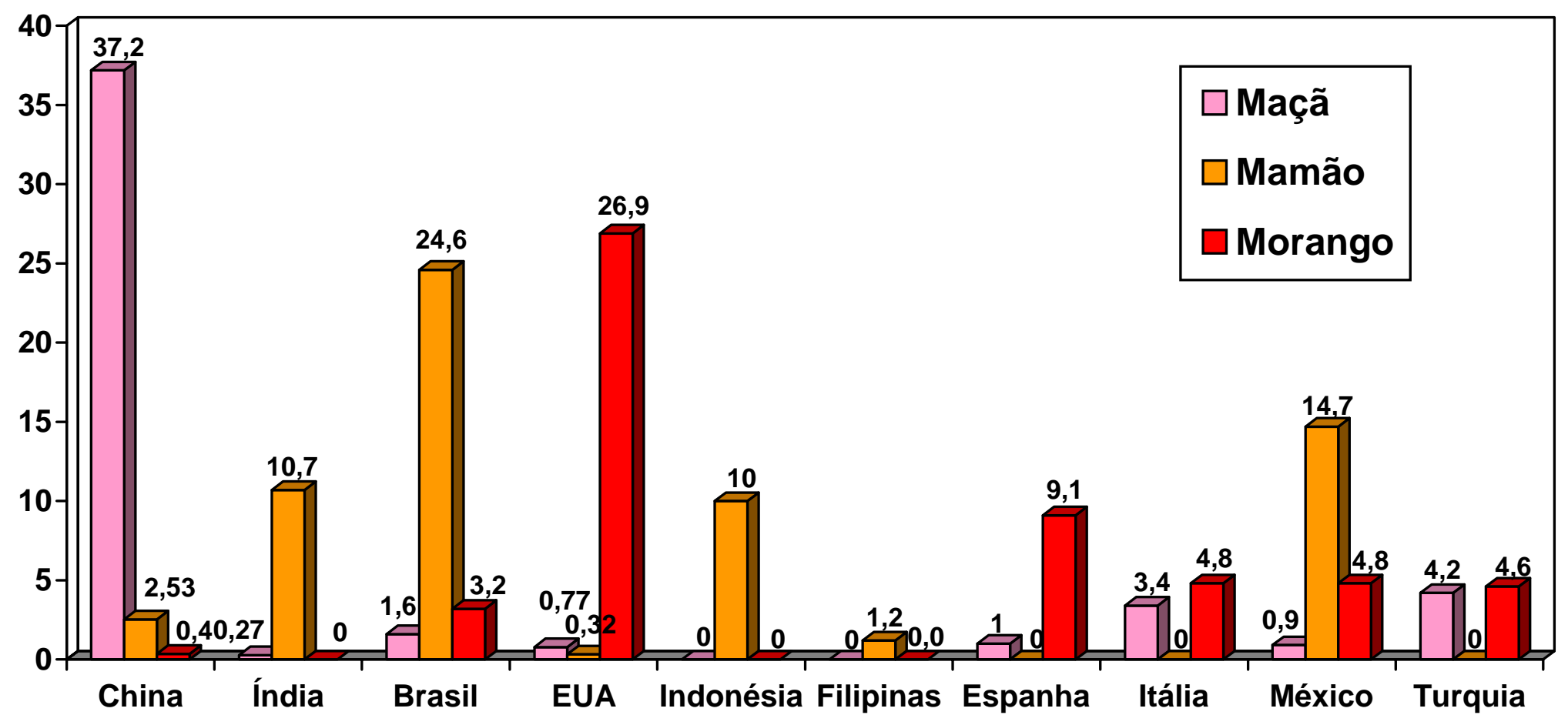

Figura 3 - Principais produtores mundiais de maçã, mamão, morango em porcentagem relativa. 
Desde que foi implantado, a PIF permitiu redução de $63 \%$ no uso de agrotóxicos nos pomares de manga; de 50\% nos de mamão; de 32\% nos de uva; e de 30\% nos de maçã (MAPA 2007e).

Dentre as principais frutas produzidas no Brasil, citadas na Tabela 14, destacase a laranja, que ocupa o $1^{\circ}$ lugar, e o caju, produzido quase que exclusivamente no país, representando $96 \%$ da produção mundial.

O Brasil é um dos maiores pólos mundiais de produção de sucos de frutas. Em 2003, as exportações do setor alcançaram 1.250.000.000 dólares. Do total, 95\% correspondem a suco de laranja, do qual o país é o maior produtor e exportador. Os principais destinos foram Bélgica, Países Baixos, Estados Unidos e Japão (MAPA 2007e).

O mamão encontra-se em $5^{\circ}$ lugar na produção nacional de frutas, com 1.600 mil toneladas (Tabela 14), sendo que a Bahia é responsável por 55\% desta produção, dos quais $80 \%$ saem do extremo sul do Estado. O mamão é exportado para vários países europeus, como Inglaterra, França, Alemanha e Portugal (SEAGRI 2005).

Apesar do Brasil ser o maior produtor de mamão do mundo (Figura 3), sua participação no mercado mundial (25\%) é ainda pequena, sendo que há previsões de crescimento nas exportações (Tabela 14).

A industrialização de produtos como purê pode ser o grande suporte ao desenvolvimento da cultura do mamoeiro, principalmente na forma de polpa congelada destinada à industrialização para compor iogurtes e sorvetes (SILVA 1999).

A maçã está no $9^{\circ}$ lugar entre as frutas de maior produção no Brasil, com 977 mil toneladas (Tabela 14). A maçã se encontra entre as culturas que possuem zoneamento agrícola no Brasil (algodão, arroz, banana, café, caju, cevada, feijão, feijão caupi, mamona, mandioca, maçã, milho, soja, sorgo, trigo e uva). 
Tabela 14 - Classificação das principais frutas produzidas no Brasil em ordem decrescente e comparação com a produção mundial

\begin{tabular}{|c|c|c|c|c|}
\hline & $\begin{array}{c}\text { Classificação } \\
\text { no } \\
\text { Brasil }\end{array}$ & $\begin{array}{c}\text { Produção } \\
\text { no } \\
\text { Brasil } \\
\text { (mil ton.) }\end{array}$ & $\begin{array}{c}\text { Produção } \\
\text { no } \\
\text { Mundo } \\
\text { (mil ton). }\end{array}$ & $\begin{array}{c}\text { Comparação } \\
\text { da produção } \\
\text { no Brasil } \\
\text { x Mundo } \\
(\%)\end{array}$ \\
\hline Laranja & $1^{\mathrm{o}}$ & 18.262 & 63.039 & 29 \\
\hline Banana & $2^{\circ}$ & 6.593 & 103.297 & 6 \\
\hline Coco & $3^{\circ}$ & 2.959 & 53.473 & 5 \\
\hline Caju & $4^{\circ}$ & 1.608 & 1.671 & 96 \\
\hline Mamão & $5^{\circ}$ & 1.600 & 6.504 & 25 \\
\hline Abacaxi & $6^{\circ}$ & 1.435 & 15.287 & 9 \\
\hline Uva & $7^{\circ}$ & 1.279 & 65.486 & 2 \\
\hline Tangerina & $8^{\circ}$ & 1.263 & 22.198 & 6 \\
\hline Maçã & $9^{\circ}$ & 977 & 59.059 & 2 \\
\hline Limão/lima & $10^{\circ}$ & 950 & 12.126 & 8 \\
\hline Manga & $11^{\circ}$ & 845 & 26.286 & 3 \\
\hline Melancia & $12^{\circ}$ & 620 & 93.481 & 1 \\
\hline Pêssego & $13^{\circ}$ & 215 & 15.561 & 1 \\
\hline Abacate & $14^{\circ}$ & 173 & 3.187 & 5 \\
\hline Melão & $15^{\circ}$ & 155 & 27.371 & 1 \\
\hline Morango & $16^{\circ}$ & $100 *$ & 3.113 & 3 \\
\hline Toranja/pomelo & $17^{\circ}$ & 67 & 4.874 & 1 \\
\hline Caqui & $18^{\circ}$ & 66 & 2.454 & 3 \\
\hline Figo & $19^{\circ}$ & 24 & 1.089 & 2 \\
\hline Pêra & $20^{\circ}$ & 20 & 17.909 & $<1(0,7)$ \\
\hline
\end{tabular}

Fonte: Adaptado de (FAO 2005 apud OLIVEIRA 2005b); * (EMBRAPA 2005a)

O Zoneamento Agrícola de Risco Climático, coordenado pela Secretaria de Política Agrícola (SPA) do Ministério da Agricultura, Pecuária e Abastecimento (MAPA), cresceu 85\% de 2003 a 2006. O número de zoneamentos aumentou de 118 
para 220 e já beneficia 16 culturas em praticamente todos os estados brasileiros. $\mathrm{O}$ instrumento é considerado de fundamental importância para promover o sucesso da atividade agrícola no Brasil, pois indica as localidades e períodos mais propícios para o plantio das culturas contempladas com o estudo de diversas espécies (MAPA 2007a).

O rendimento médio da produção de maçã no Brasil em 2005 foi de 23.522 $\mathrm{kg} / \mathrm{ha}$. Os Estados que mais contribuíram (em ordem decrescente) foram Santa Catarina, Rio Grande do Sul, Paraná e São Paulo, com área colhida de 19, 15, 2 e <1 mil hectares, respectivamente (MAPA 2005).

O Brasil não figura entre os maiores produtores de morango, estando em torno de 100 mil toneladas ao ano, concentradas principalmente nas Regiões Sudeste e Sul, sendo que Minas Gerais produz mais de 30 mil toneladas; São Paulo 29 mil toneladas e Rio Grande do Sul 11 mil toneladas, representando, juntos, mais de 80\% da produção nacional (EMBRAPA 2005a).

Em São Paulo, as plantações de morango estão concentradas em Campinas, Jundiaí e Atibaia, sendo que esta última representa $60 \%$ da área cultivada (EMBRAPA 2005a).

\subsubsection{Escolha das matrizes de estudo - Frutas}

A escolha por trabalhar com frutas deve-se ao fato de serem ingeridas in natura, por existir a possibilidade de conter resíduos de etilenotiouréia, pois os etilenobisditiocarbamatos são autorizados para uso para praticamente todas as frutas, e pelo seu consumo ser expressivo na dieta do brasileiro.

Entre os produtos de origem vegetal, segundo pesquisa de Orçamentos Familiares no município de São Paulo, as frutas apresentaram consumo alimentar per capita anual de 28,486 kg; as hortaliças de 30,084 kg; os cereais e leguminosas de $33,126 \mathrm{~kg}$, os cocos de $0,232 \mathrm{~kg}$ e as castanhas e nozes de 0,058 $\mathrm{kg}$ (IBGE 2005).

As frutas que apresentaram maior consumo na cidade de São Paulo em ordem decrescente de consumo alimentar per capita anual foram: laranja $(8,206 \mathrm{Kg})$, banana $(7,520 \mathrm{~kg})$, melancia $(2,874 \mathrm{~kg})$, mamão $(2,127 \mathrm{~kg})$, maçã $(2,009 \mathrm{~kg})$, manga $(1,054 \mathrm{~kg})$, uva $(0,699 \mathrm{~kg})$ e outras de clima temperado, incluindo o morango $(0,134$ kg) (IBGE 2005). 
Apesar da laranja e da banana apresentarem maiores consumos, dados de monitoramento de resíduos de agrotóxicos em alimentos, realizados no Brasil, não revelaram índices consideráveis de resíduos de ditiocarbamatos nas amostras analisadas (ANVISA 2003), sendo, portanto, menos provável encontrar resíduos de ETU nessas matrizes do que em outras que apresentaram maiores índices de contaminação por esses resíduos, como mamão, maçã e morango.

Foi dada preferência para os frutos que geralmente são consumidos com casca. No caso, a maçã e o morango se enquadram nesse critério. Ficaram excluídos por este critério: laranja, banana, mamão, melância, manga. Porém, o mamão, além de estar em $3^{\circ}$ lugar em consumo, depois da laranja e banana, tem apresentado resíduos de ditiocarbamatos e ETU em estudos anteriores. Além disso, algumas receitas caseiras incluem a casca no consumo.

Apesar do consumo per capita anual da uva ser maior do que o do morango (IBGE 2005), de poder ser consumida com e sem a casca e de possuir autorização para uso de EBDC nas culturas, foi dada preferêcia para o morango pelos motivos descritos a seguir.

O morango é muito apreciado pela população e, em especial as crianças, e está freqüentemente presente em inúmeras receitas de bolos, tortas, sucos, iogurtes entre outras. Tem apresentado índices de contaminação por ditiocarbamatos. Crianças também apreciam e consomem doces e massas com morango. Além disso, houve alteração na legislação, que a partir de 02/09/2003 estabeleceu o uso do metam sódico e desautorizou o uso de manebe (EBDC) em cultura de morango. Portanto, foi considerado importante verificar se a medida trouxe alguma repercussão para a saúde pública, com diminuição dos resíduos no morango.

Resíduos de ditiocarbamatos têm sido encontrados em amostras de maçã, mamão e morango em estudos realizados no Brasil (descritos na Discussão).

Existem poucos trabalhos relacionados ao monitoramento de ETU em frutas no Brasil.

$\mathrm{O}$ consumo de frutas traz inúmeros benefícios à saúde, pois são ricas em vitaminas e minerais, entre outros componentes, conforme pode ser observado na Tabela 15. 
Tabela 15 - Composição da parte comestível das frutas estudadas: calorias, nutrimentos, minerais, vitaminas, aminoácidos e porcentagem de resíduo.

\begin{tabular}{|c|c|c|c|c|}
\hline \multicolumn{2}{|c|}{ Composição } & \multicolumn{3}{c|}{ Frutas } \\
\hline Componentes & Unidade & maçã & mamão & morango \\
\hline Calorias & $(\mathrm{kcal} / 100 \mathrm{~g})$ & $\mathbf{5 8}$ & $\mathbf{3 2}$ & $\mathbf{3 6}$ \\
\hline Umidade & $(\mathrm{g} / 100 \mathrm{~g})$ & $\mathbf{8 4 , 0}$ & $\mathbf{9 0 , 7}$ & $\mathbf{9 0 , 0}$ \\
\hline Proteínas & $(\mathrm{g} / 100 \mathrm{~g})$ & $\mathbf{0 , 3}$ & $\mathbf{0 , 5}$ & $\mathbf{0 , 8}$ \\
\hline Lipídeos & $(\mathrm{g} / 100 \mathrm{~g})$ & $\mathbf{0 , 3}$ & $\mathbf{0 , 1}$ & $\mathbf{0 , 3}$ \\
\hline Glicídeos & $(\mathrm{g} / 100 \mathrm{~g})$ & $\mathbf{1 5 , 2}$ & $\mathbf{8 , 3}$ & $\mathbf{8 , 5}$ \\
\hline Fibra & $(\mathrm{g} / 100 \mathrm{~g})$ & $\mathbf{0 , 7}$ & $\mathbf{0 , 6}$ & $\mathbf{1 , 3}$ \\
\hline Cinzas & $(\mathrm{g} / 100 \mathrm{~g})$ & $\mathbf{0 , 2}$ & $\mathbf{0 , 4}$ & $\mathbf{0 , 4}$ \\
\hline Cálcio & $(\mathrm{mg} / 100 \mathrm{~g})$ & $\mathbf{6}$ & $\mathbf{2 0}$ & $\mathbf{2 9}$ \\
\hline Fósforo & $(\mathrm{mg} / 100 \mathrm{~g})$ & $\mathbf{1 0}$ & $\mathbf{1 3}$ & $\mathbf{2 9}$ \\
\hline Ferro & $(\mathrm{mg} / 100 \mathrm{~g})$ & $\mathbf{0 , 4}$ & $\mathbf{0 , 4}$ & $\mathbf{1 , 0}$ \\
\hline Retinol equivalente & $(\mathrm{mmg})$ & $\mathbf{3}$ & $\mathbf{3 7}$ & $\mathbf{3}$ \\
\hline Vitamina B1 & $(\mathrm{mg} / 100 \mathrm{~g})$ & $\mathbf{0 , 0 3}$ & $\mathbf{0 , 0 3}$ & $\mathbf{0 , 0 3}$ \\
\hline Vitamina B2 & $(\mathrm{mg} / 100 \mathrm{~g})$ & $\mathbf{0 , 0 5}$ & $\mathbf{0 , 0 4}$ & $\mathbf{0 , 0 4}$ \\
\hline Niacina & $(\mathrm{mg} / 100 \mathrm{~g})$ & $\mathbf{0 , 2}$ & $\mathbf{0 , 3}$ & $\mathbf{0 , 4}$ \\
\hline Vitamina C & $(\mathrm{mg} / 100 \mathrm{~g})$ & $\mathbf{6}$ & $\mathbf{4 6}$ & $\mathbf{7 0}$ \\
\hline Lisina & $(\mathrm{mg} / \mathrm{g}$ de $\mathrm{N})$ & $\mathbf{3 7 0}$ & $\mathbf{3 1 6}$ & $\mathbf{2 5 0}$ \\
\hline Metionina/Cistina & $(\mathrm{mg} / \mathrm{g} \mathrm{de} \mathrm{N})$ & $\mathbf{1 3 3}$ & $\mathbf{1 7 8}$ & $\mathbf{6 5}$ \\
\hline Treonina & $(\mathrm{mg} / \mathrm{g}$ de $\mathrm{N})$ & $\mathbf{2 3 0}$ & $\mathbf{2 1 9}$ & $\mathbf{1 9 0}$ \\
\hline Triptofano & $(\mathrm{mg} / \mathrm{g} \mathrm{de} \mathrm{N})$ & $\mathbf{5 8}$ & $\mathbf{5 7}$ & $\mathbf{7 2}$ \\
\hline Parte não comestível & $(\%)$ & $\mathbf{1 2}$ & $\mathbf{2 9 , 1}$ & $\mathbf{1 0 , 8}$ \\
\hline
\end{tabular}

Fonte: Fundação Instituto Brasileiro de Geografia e Estatística (IBGE) /Estudo Nacional da Despesa Familiar (ENDEF) (IBGE/ENDEF 1985). 


\subsubsection{Hábitos de consumo relativos às frutas estudadas}

Os principais hábitos de consumo no Brasil estão descritos a seguir.

\section{- Maçã}

A maçã é consumida in natura e em produtos industrializados como sucos, vinagre, bebidas alcoólicas, geléias, compotas, doces e também em grande variedade de receitas caseiras.

Devido ao alto teor de potássio de aproximadamente $120 \mathrm{mg}$ por $100 \mathrm{~g}$ ( e por apresentar boa qualidade de fibras, a maçã é indicada para a manutenção da saúde, para prevenção de doenças cardíacas, para diminuir o excesso de colesterol no sangue e para dietas alimentares de emagrecimento.

\section{- Mamão}

Consumido in natura ou na forma de doces.

Apesar de serem geralmente desprezadas, as sementes são comestíveis e constam alguns usos medicinais, tais como vermífugos ou como auxiliar no funcionamento da digestão (SILVA 1999).

Receitas que utilizam o mamão verde podem incluir a casca para consumo. Podese consumir o mamão verde em doces e pratos salgados, cortado em pedaços pequenos e refogado, em sopas e ensopados de carne.

$\mathrm{O}$ fruto maduro é utilizado para fabricar mamão desidratado, doce em calda e outros produtos industrializados, como iogurtes e sorvetes.

A papaína que se encontra especialmente no mamão verde é uma substância de muitos usos medicinais e industriais, sendo que, na medicina caseira, foi utilizada para extirpar verrugas e, na culinária, como amaciante de carnes (SILVA 1999).

\section{- Morango}

O morango é consumido in natura ou por meio de múltiplas maneiras de processamento ou receitas caseiras, como bolos, tortas, doces. Existem muitos produtos industrializados: sucos, geléias, iogurtes, doces, compotas, sorvetes, licores, entre outros.

Deve-se considerar que bebês e crianças consomem frutas in natura e legumes cozidos e industrializados desde os primeiros meses de vida e, por apresentarem menor peso corpóreo, o risco de ingestão de ETU ou de outro contaminante pelo consumo de alimento é maior do que no adulto (LEMES 2003). Bebês e crianças 
possuem capacidade metabólica reduzida na eliminação de produtos tóxicos e são mais susceptíveis a toxicantes que atuam no sistema nervoso central (PEREIRA 2005), sendo importante o conhecimento de dados de resíduos em produtos consumidos por estas faixas etárias.

\subsubsection{A cultura de maçã (Malus Silvestris Mill.)}

Acredita-se que a evolução da macieira iniciou há 25 milhões de anos. Não se sabe ao certo qual ou quais foram as espécies silvestres que deram origem à maçã contemporânea, cujas variedades são atualmente conhecidas. Pode ser, por exemplo, a Malus prinifolia, originária na região entre o Cáucaso e o Leste da China, ou a Malus sylvestris, originária da Europa. As espécies de macieiras atualmente conhecidas se desenvolveram há 20 mil anos, após o final da última era glacial (SRJUNDIAI - SINDICATO RURAL DE JUNDIAÍ 2005a). Nas regiões temperadas, a macieira é cultivada há muitos milênios.

A macieira é uma das frutíferas que dispõe de grande número de cultivares. Atualmente, são descritas mais de 7.000, porém comercialmente são poucas as que se destacam. No Brasil, a produção de maçã está concentrada em duas cultivares, Gala e Fuji, que representam em torno de $90 \%$ da área plantada. As demais cultivares incluem a Eva, a Golden Delicious, a Brasil, a Anna, a Condesa, a Catarina e a Granny Smith (ABPM 2003c apud IHA 2006).

Muito bem adaptada aos climas regionais brasileiros, provém especialmente do Sul e do Sudeste do país, nos quais os estados de Santa Catarina, Rio Grande do Sul, São Paulo e Paraná são responsáveis pela quase totalidade de volume produzido. (SRJUNDIAI 2005a).

As árvores chegam a 10 metros de altura com tronco de casca lisa e copa arredondada e flores brancas ou róseas, aromáticas. 


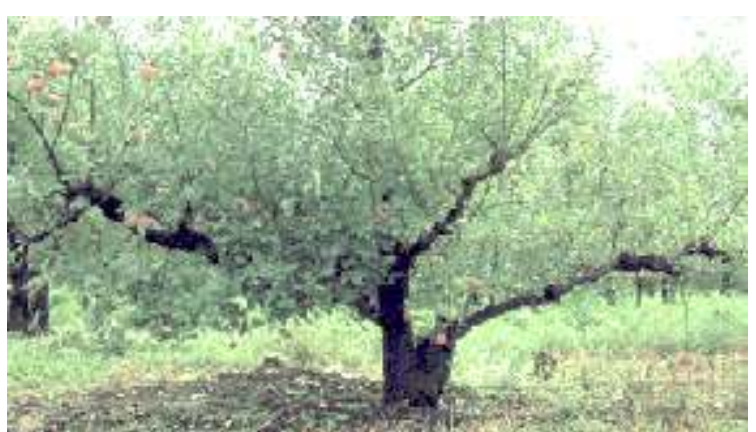

Figura 4 - Macieira

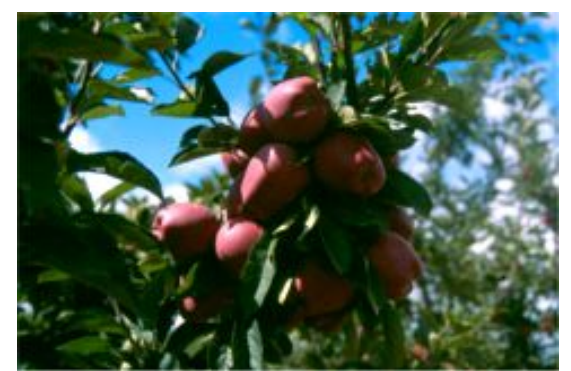

Figura 5 - Frutos da macieira

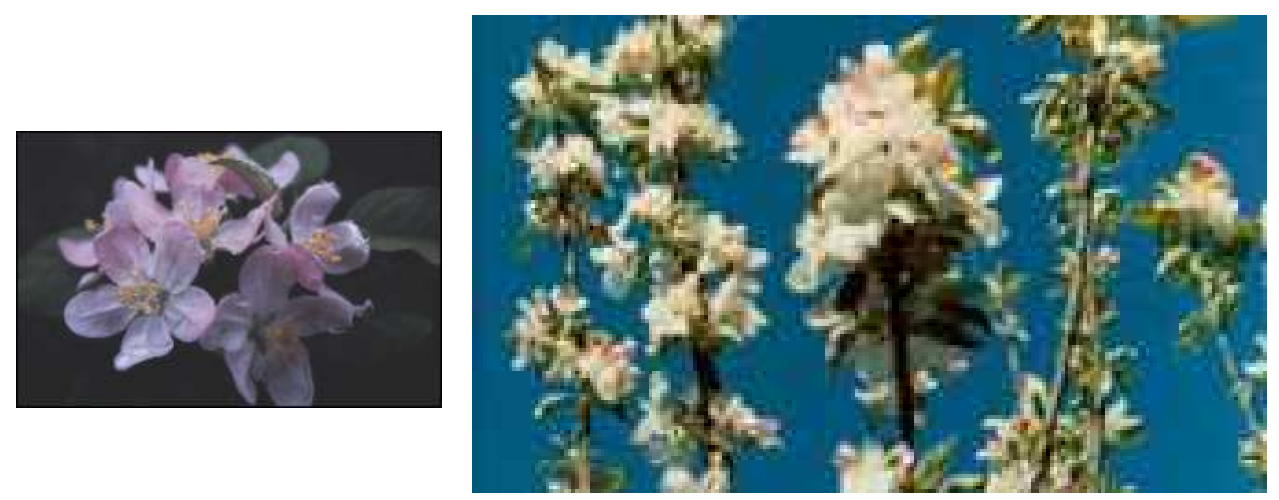

Figura 6 - Flores da macieira

Figura 7 - Ramos em flor da macieira

Os meses mais indicados para o plantio da macieira são os de julho-agosto (inverno), com uso de mudas enxertadas de raízes nuas. As mudas são plantadas em covas com as dimensões de $60 \mathrm{~m}$ x $60 \mathrm{~cm}$ x $60 \mathrm{~cm}$, com espaçamento de $6 \mathrm{~m}$ por $5 \mathrm{~m}$ entre as plantas. Há necessidade de poda de formação, limpeza e frutificação para que a planta seja corretamente formada e produza frutos de boa qualidade. As capinas devem ser feitas periodicamente para manter a cultura limpa. A irrigação é indispensável no período de brotação (após a poda) nos meses de agosto, setembro e outubro em virtude da baixa precipitação pluviométrica (SRJUNDIAÍ 2005a).

Além das necessidades básicas de nitrogênio, fósforo, potássio, cálcio, magnésio e enxofre, a macieira necessita de boro e zinco como micronutrientes que ocorrem em teores insuficientes na maioria dos solos do Estado de São Paulo (SRJUNDIAÍ 2005a)

Geralmente são usados agrotóxicos para controle de pragas e moléstias das macieiras e o uso dos mesmos deve ser feito de acordo com as Boas Práticas Agrícolas. Por exemplo, durante o período vegetativo, faz-se pulverizações com 
fungicidas como zinebe, captana, mancozebe, etc, além de inseticidas (SRJUNDIAÍ 2005a).

No Estado de São Paulo, em virtude do clima mais quente do que na região sul do Brasil, a colheita se inícia no mês de dezembro, terminando em fevereiro do ano seguinte (SRJUNDIAÍ 2005a).

Em pomares comerciais a produção esperada é de 20 a 30 toneladas de frutos por hectare (SRJUNDIAÍ 2005a).

\section{- Características do fruto}

A maçã é um fruto globoso com uma profunda depressão no ponto de inserção da haste que o prende aos ramos. De coloração vermelha ou verde, podendo apresentar pequenas manchas esverdeadas ou amareladas. Frutifica de fevereiro a abril.

As variedades mais cultivadas de maçã no Brasil são: gala, fuji e golden delicious. As maçãs podem ser classificadas e agrupadas pela qualidade, sabor, tamanho, forma, aparência, consistência da polpa e da casca e utilidade.

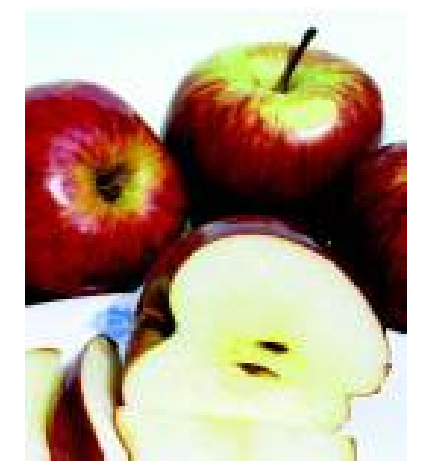

\section{Figura 8 - Maçãs}

\subsubsection{A cultura de mamão}

Presume-se que o mamão tenha nascido na América tropical, onde se encontram ainda todas as espécies descritas para o gênero Carica, estando a maioria delas espalhadas ao pé dos Andes, na Colômbia, Equador e Peru. Dali, das encostas ensolaradas dos Andes, a fruta teria rapidamente se espalhado por todo o continente, 
devido à velocidade de seu ciclo vital, à facilidade com que a planta se propaga e se multiplica e à rapidez com que nascem seus frutos (SILVA 1999).

$\mathrm{O}$ mamoeiro cresce rápido e produz bastante, florescendo e frutificando muitas vezes ao mesmo tempo e durante o ano todo, de preferência em regiões de clima quente e úmido. Alcança de três a seis metros de altura. O caule herbáceo lenhoso, oco, cilíndrico e simples é, às vezes, ramificado com ápice, coroado por um topo de folhas grandes digitilobadas, com grandes pecíolos. As flores são esbranquiçadas ou amareladas fragrantes e unissexuais.

Distinguem-se duas plantas: o mamoeiro fêmea e o macho, com diferença apenas nas inflorescências e conseqüentemente nos frutos. No mamoeiro fêmea, as flores são exclusivamente femininas, grandes, campanuladas, subsésseis, solitárias ou em inflorescências axilares pouco numerosas e os frutos são bagas arredondadas. No mamoeiro macho, as flores são agrupadas em longos pedúnculos paniculados, a corda é tubulosa. $\mathrm{Na}$ extremidade, os frutos pequenos surgem com flores hermafroditas que dão origem a frutos pequenos, compridos ou ovais. Os frutos provenientes de flores hermafroditas são alongados, com polpa mais espessa e, conseqüentemente, com cavidade central menor, por isso preferidas comercialmente. A cor da polpa é outra característica importante, sendo preferidos os frutos que apresentam coloração vermelha ou vermelho-rosado.

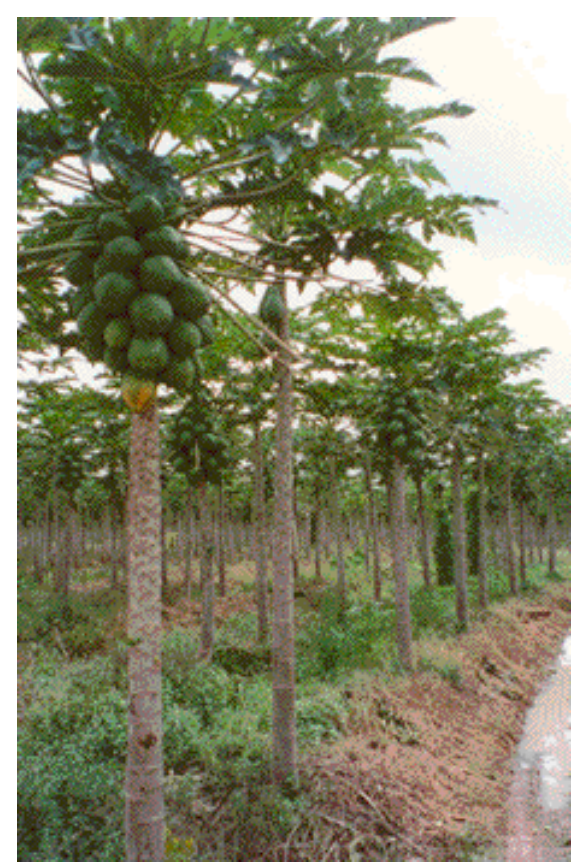

Figura 9 - Cultura de mamão

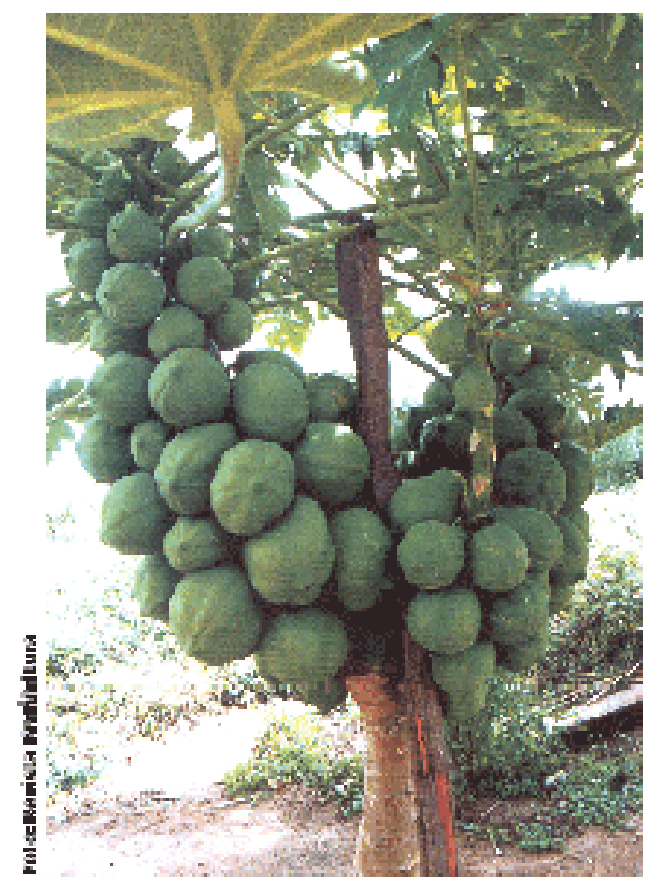

Figura 10 - Frutos do mamoeiro 
Até o final da década de 1970, no Brasil, predominavam plantios de mamoeiro dióico ou comum, com produção destinada exclusivamente ao mercado interno, destacando-se o Estado de São Paulo como principal produtor. Porém, a ocorrência do vírus do mosaico provocou redução dos pomares e migração dessa caricacea para outros Estados (RUGGIERO 1980).

Na década de 1970 foi introduzida no mercado uma nova variedade de mamão (Carica Papaya L.), menor e mais doce do que o mamão comum.

A espécie Carica Papaya L. é o mamoeiro mais cultivado do mundo, com origem provável na Bacia Amazônica Superior, noroeste da América do Sul. No Brasil foi produzida inicialmente no Pará, tendo seu cultivo difundido para várias regiões tropicais do país. Segundo dados do IBGE, as maiores produções são oriundas do Nordeste, especialmente das regiões irrigadas do Vale do Rio São Francisco, nos Estados da Bahia e de Pernambuco; do Espírito Santo; do Pará, no norte do país (TRINDADE 1999; SILVA 1999).

\section{- Características do Mamão (Carica Papaya L.)}

O mamão Carica Papaya L. é também conhecido popularmente como mamãodo-amazonas ou mamãozinho.

A fruta tomou conta do mercado rapidamente em virtude de seu sabor, sempre doce, e de seu tamanho, ideal para o consumo individual (SILVA 1999).

Os frutos são pequenos, ovais, têm casca lisa, fina e resistente, verde-escura que se tornam amareladas ou alaranjadas com o amadurecimento. A polpa é doce, alaranjada ou avermelhada, suculenta e aromática. O fruto é oco com numerosas sementes pretas revestidas por uma excrescência mucilaginosa de sabor levemente picante.

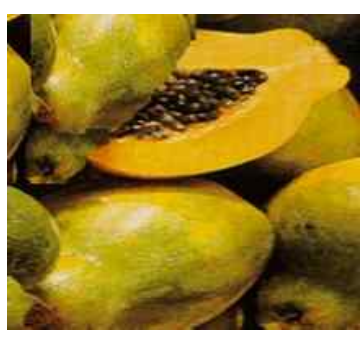

Figura 11 - Mamões C.Papaya L 


\subsection{A cultura de morango (Fragaria Vesca L.)}

O morangueiro é uma espécie olerícola, produzida por erva rasteira, originária da Europa, possui inúmeras variedades naturais e híbridas e exige grande disponibilidade hídrica (aspersão ou gotejamento) e cobertura do solo para atingir altas produções, que deve ser feita após o plantio das mudas para evitar o contato dos frutos com o mesmo, impedir a proliferação de fungos, a invasão de ervas daninhas, manter a umidade e evitar a morte das raízes superficiais (EMBRAPA 2005a; SRJUNDIAÍ 2005b).

O cultivo de morango no Brasil começou expandir-se a partir de 1960 nos Estados do Rio Grande do Sul, São Paulo e Minas Gerais, e desenvolveu-se também em regiões de diferentes solos e climas, como Goiás, Santa Catarina, Espírito Santo e Distrito Federal (EMBRAPA 2005a).

A época de colheita compreende o período de agosto a dezembro, em regiões mais frias, como o Sul do Brasil, e se inicia entre 60 e 80 dias após o plantio das mudas, podendo se prolongar por 4 a 6 meses, dependendo da disponibilidade de água e luz. A colheita é realizada manualmente, colhendo-se os frutos maduros, para fins industriais, e de $1 / 2$ a $3 / 4$ maduros para comercialização in natura (EMBRAPA 2005a).

É uma das poucas frutas na qual a colheita no campo, a seleção, a classificação e a embalagem são realizadas pela mesma pessoa.

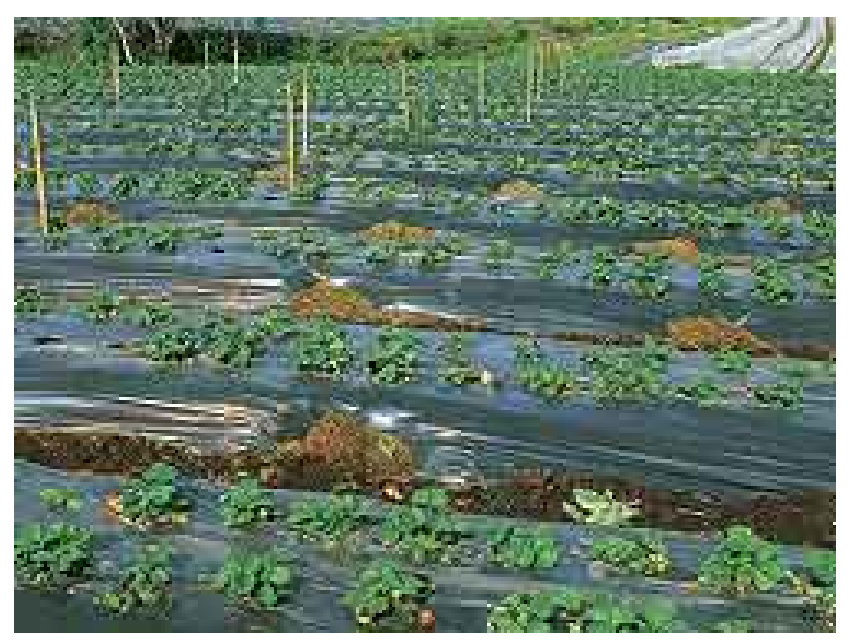

Figura 12 - Plantação de morango 


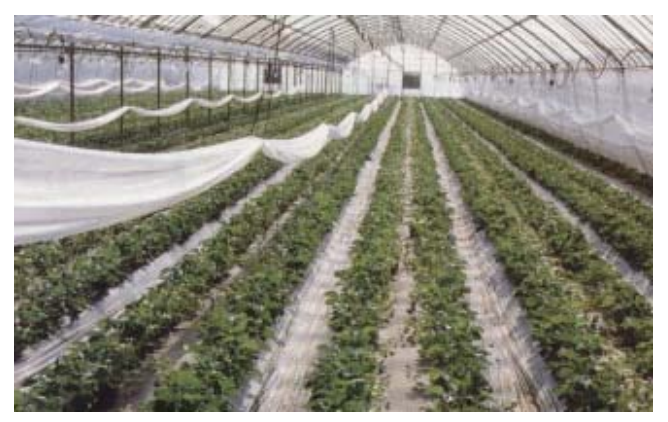

Figura 13 - Plantação de morangos - com proteção aérea

\section{- Cultivares do morango}

As cultivares apresentam características diferentes, dependendo da região onde são plantadas. Elas encontram-se divididas segundo uso na indústria ou para consumo in natura. As principais cultivares com destino ao consumo in natura são: Campinas, Oso Grande, Tudla, Selva e Seascape. Com destino à indústria são: Santa Clara, Burlkey, Dover. Ainda há os que podem se destinar às duas finalidades, como o Chandker (EMBRAPA 2005a; SRJUNDIAÍ 2005a).

A ampla zona de produção do morango (regiões Sudeste e Sul) implica variações endafoclimáticas que influem na fertilidade do solo e no comportamento vegetativo dos cultivares (EMBRAPA 2005a).

Campinas - Apresenta produção boa e precoce, com frutificação fora da área das folhas, o que facilita a colheita. Os frutos são grandes, alongados, de formato cônico e com haste regularmente firme, o cálice destaca-se facilmente do fruto. (EMBRAPA 2005a; SRJUNDIAÍ 2005b). Apresenta boa tolerância à mancha angular, porém é susceptível à antracnose e à murcha de verticilium (EMBRAPA 2005a).

Oso Grande - Cultivar de grande adaptabilidade; planta vigorosa com folhas grandes e de coloração verde escura; ciclo mediano e de elevada capacidade produtiva. Frutos de tamanho grande, polpa de textura firme no início da produção e mediana no final da colheita, de coloração vermelha aromática; epiderme vermelha clara; sabor subácido, próprio para consumo in natura. É tolerante ao mofo cinzento e susceptível à micosfarela e à antracnose (EMBRAPA 2005a).

Tudla Milsey - Planta vigorosa com folhas grandes de coloração verde escura; ciclo tardio e com grande capacidade produtiva. Frutos de formato cônico ou 
de cunha alongada, de tamanho grande, polpa de textura firme e de coloração vermelha; epiderme vermelha; sabor subácido (EMBRAPA 2005a). É tolerante ao mofo cinzento e susceptível à mancha de micosfarela e à antracnose (EMBRAPA 2005a).

Santa Clara - Planta de alto vigor, boa densidade de folhas que recobrem os frutos. Frutos de tamanho médio, formato irregular, epiderme vermelha escura; polpa de textura média e cor vermelha uniforme (EMBRAPA 2005a). Resistente à mancha de micosfarela, à diplocarpon e à mancha de dendrofoma, tolerante à antracnose (EMBRAPA 2005a).

Bürkley - Planta de alto vigor; folhas grandes e de coloração verde escura; muito alta capacidade de produção e ciclo precoce. Frutos grandes, polpa de textura média e de coloração vermelha clara, sabor ácido próprio para a industrialização. Resistente à micosfarela, à murcha de verticillium e à murcha de dendrofona, tolerante à murcha de diplocorpon e à antracnose e susceptível ao mofo cinzento (EMBRAPA 2005a).

Dover - Planta de vigor médio, coroa grossa, produção inicial precoce, produtividade alta, fruto grande de formato cônico-alongado, epiderme e polpa firmes de coloração vermelho-intenso, pouco ácido e de aroma pouco evidenciado (SRJUNDIAÍ 2005b).

Chandler - Planta de alto vigor, densidade de folha média, coroa grossa, produção inicial tardia, produtividade alta. O formato do fruto é grande, cônico e alongado. A epiderme e a polpa são de coloração vermelho escuro, com sabor subácido e aroma ativo. Suas frutas primárias e secundárias são grandes e as terciárias e quaternárias são pequenas. Pode ser utilizado para consumo e para indústria (SRJUNDIAÍ 2005b).

\section{- Características do morango}

O morango é um fruto de clima temperado, vermelho (quando maduro), carnoso e aromático, apresenta textura suculenta, aspecto, sabor e odor agradáveis, sendo muito apreciado e valorizado. Porém, é altamente perecível e pode ser estocado apenas por pequenos períodos. O congelamento é uma alternativa para 
ampliar sua disponibilidade, pois proporciona menos danos aos frutos, tanto do ponto de vista nutricional como sensorial (SRJUNDIAÍ 2005b; EMBRAPA 2005a).

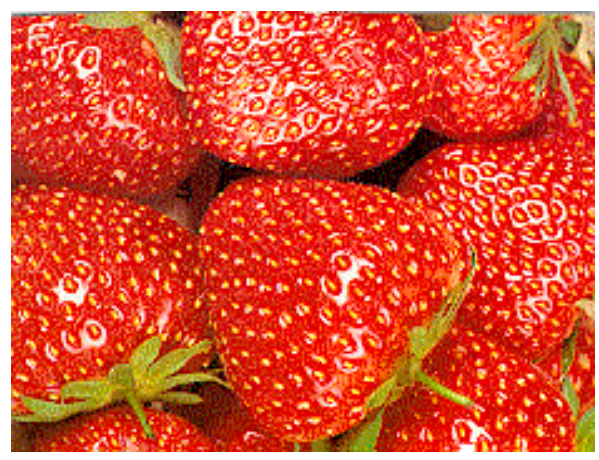

Figura 14 - Morangos

\subsection{Doenças nas culturas}

\subsubsection{Principais doenças que afetam a cultura de maçã}

A maior produção brasileira de maçã é na região Sul, com cultivares importadas, onde as temperaturas e o regime de chuvas são elevados durante o verão e favorecem o desenvolvimento de doenças, como a podridão amarga.

A podridão amarga, causada pelo fungo Glomerella cingulata, é uma das mais importantes doenças de verão, podendo ocasionar perdas muito elevadas, sendo susceptíveis os cultivares gala, fuji e "golden delicious". Embora o fungo possa atacar frutos intactos, a agressividade parece ser maior e a evolução da doença mais rápida em frutos com ferimentos, sendo mais suscetíveis no ponto de consumo. Portanto, deve-se manter os frutos bem protegidos do ataque de insetos, notadamente a mosca-das-frutas, Anastrepha fraterculus, pois há baixa incidência de lesões de podridão amarga na ausência de ferimentos. De acordo com Camilo e Denardi (2001), existe possibilidade de segregação genética para resistência a G. cingulata em macieira, tornando viável o desenvolvimento de cultivares resistentes, mesmo a partir de cruzamentos entre alguns conhecidos como susceptíveis (CAMILO E DENARDI 2001).

Denardi e col. (2005) realizaram um estudo de resistência genética à podridão amarga em maçãs, comparando taxas de desenvolvimento da doença em frutos com e sem ferimentos, e concluíram que o estabelecimento e desenvolvimento da doença mostraram-se muito mais rápido através de ferimentos. As seleções M-6/00 e M- 
13/00 estudadas manifestaram maiores resistências do que nas cultivares gala, fuji, golden delicious, e também na melrose, indicada como resistente em outros estudos.

Ácaro-vermelho - Pamonychus ulmi Koch (Acari; Tetranychidae) considerado praga-chave da macieira no Sul do Brasil. O controle biológico é uma das estratégias para o controle deste ácaro.

Com o objetivo de definir uma estratégia de controle do ácaro vermelho da macieira, associando o controle biológico com o controle químico, por meio da multiplicação e de liberação inundativa de Neoseiulus califormnicus MacGregor e da seleção de inseticidas menos tóxicos aos ácaros predadores, Monteiro (2002) realizou um estudo de manejo integrado de pragas em macieira no Rio Grande do Sul e obteve os seguintes resultados: no primeiro ano foi utilizada a associação de acaricidas com ácaros predadores e houve reduzido número de ovos de inverno do ácaro-vermelho; no segundo ano, 58\% das macieiras não foram pulverizadas com acaricidas e, nos dois anos subseqüentes, o controle do ácaro-vermelho foi realizado exclusivamente com ácaros predadores. $N$. californicus passou o inverno nas ervas daninhas do pomar e migrou espontaneamente para a copa das macieiras nos anos subseqüentes a sua introdução.

A Bonagota cranaodes (Meyrick) (Lepidóptera; Tortricidae) é uma importante praga na cultura da macieira, causando perdas anuais de $3 \%$ a $5 \%$ da produção. Os danos são causados pelas lagartas que raspam a casca das maçãs, provocando a depreciação do fruto. As posturas são realizadas na parte adaxial das folhas em forma de uma massa, contendo, em média, 40 ovos por postura. O controle de B. cranaodes com inseticidas não tem proporcionado resultados satisfatórios O controle biológico poderia ser uma alternativa ao químico, entretanto poucos são os estudos e registros de inimigos naturais associados à praga. Monteiro e col (2004) identificaram parasitóides de ovos de B. cranaodes em pomares comerciais de macieira no Brasil que foram identificados como Trichogramma pretiosum Riley, sendo o primeiro registro de ocorrência no Brasil (MONTEIRO e col 2004).

Camilo e Denardi (2001) estudaram o efeito do carbaril sobre o "russeting" da maçã (Malus domestica BORKH) nos cultivares gala, fuji e golden delicious. O "russeting" da maçã caracteriza-se por uma camada de cortiça formada entre as células da epiderme e que dá um aspecto de rugosidade à superfície do fruto, 
depreciando-o para a comercialização. O raleio de frutos é uma prática cultural bastante difundida entre os produtores de maçã. Pode ser efetuado manualmente, quimicamente ou pela associação de ambos. Concluíram que o uso da formulação concentrada de carbaril acentuou o "russeting" em golden delicious e, neste caso, sugeriram a utilização de formulação na forma de pó molhável; entretanto, não houve alteração nas demais cultivares avaliadas.

Pesquisas que visam o melhoramento genético da macieira têm sido realizadas e têm demonstrado avanços significativos no desenvolvimento de cultivares e seleções resistentes a importantes doenças, como a sarna (Venturia inaequalis) e a mancha foliar de Glomerella (C.gloeosporioides), nos últimos anos. A incorporação de resistência simultânea a estas duas doenças e à podridão amarga, principais doenças da macieira no sul do Brasil, poderá reduzir o uso de fungicidas em mais de $80 \%$. Isto terá efeitos imediatos, não apenas na redução dos custos de produção, mas também na proteção do produtor, na saúde do consumidor e na preservação do meio ambiente (DENARDI e col 2005).

\subsubsection{Principais doenças que afetam a cultura de mamão}

O mamoeiro é muito sensível às variações climáticas e ambientais principalmente quando ainda jovem. Pode ser afetado por grande número de viroses e doenças fúngicas.

As viroses mais importantes são a mancha anelar, o amarelo letal e a meleira. As principais doenças fúngicas são estiolamento ou tombamento das mudas, podridões de Phytophttora, antracnose, varíola ou pinta preta e podridão de Phoma. Está sujeito também ao ataque de ácaros e insetos. O ácaro branco ou do ponteiro e o ácaro rajado merecem destaque pela maior ocorrência nas regiões produtoras. Vários gêneros de nematóides já foram encontrados em rizosfera de mamoeiro. Porém, os formadores dos galhos e o nematóide reniforme são considerados os de maior importância econômica (TRINDADE 1999).

A antracnose é considerada a principal doença dos frutos do mamoeiro, podendo afetar o fruto em qualquer estágio de desenvolvimento e ocorrendo com maior intensidade nos frutos maduros, tornando-os inadequados para a comercialização e consumo. Ainda que os frutos colhidos não apresentem sinais da 
doença, ela pode se manifestar nas fases de embalagem, de transporte, de amadurecimento e de comercialização, causando grandes percentagens de perdas (TRINDADE 2000).

Para controle da antracnose são utilizadas pulverizações quinzenais, com produtos à base de cobre, benzimidazol associado a clorotalonil ou EBDC.

Uma outra doença muito comum no mamoeiro é a varíola, caracterizada por pintas pretas ou bexigas nas superfícies dos frutos e, apesar de não ocasionem sérios prejuízos, como em outras podridões, resultam em grande desvalorização comercial da fruta.

O controle da varíola é feito com os mesmos fungicidas recomendados para o controle da antracnose, com pulverizações quando a lesão é ainda inicial. Outras doenças fúngicas provocam a podridão terminal do caule do mamoeiro bem como as podridões do pedúnculo e dos frutos durante o período de armazenamento e maturação. O controle de podridões externas é realizado ainda no campo na mesma época em que se controla a antracnose, com a aplicação dos fungicidas já citados. Após são realizados tratamentos pós-colheita, antes da embalagem, com o objetivo de evitar a podridão interna dos frutos (TRINDADE 2000).

\subsubsection{Principais doenças que afetam a cultura de morango}

Um dos principais problemas na cultura do morango é a incidência de doenças, que podem aparecer em várias fases do ciclo da cultura, atacando desde a muda recém plantada até os frutos na fase final da produção (EMBRAPA 2005a).

Destacam-se a antracnose, as manchas foliares, as murchas e as podridões dos fungos, dentre as doenças fúngicas.

A mais importante das manchas foliares (mancha-de-micosferela, mancha-dedipocarpon, mancha-de-dentrofoma) é a mancha-de-micosferela.

No grupo das murchas e podridões do rizoma e das raízes encontram-se vários fungos que normalmente habitam o solo e atacam as plantas, causando podridões no rizoma, sendo que as folhas mais velhas murcham e evoluem para crestamento e morte.

Dentre os principais fungos causadores das podridões encontram-se: Verticillium albo-atrum, Phytophhora sp, Fusarium sp, Rhizoctonia solani, Pythium $s p$, etc. 
Alguns fungos causadores das podridões podem afetar diretamente o morango, no campo ou durante o processo de comercialização, sendo que danos mecânicos e aquecimento provocado pela cobertura plástica podem favorecer a ação fúngica. Os principais fungos causadores dessas podridões são Botrytis cinérea, que causam o mofo-cinzento; Colletotrichum sp; Phytophthora sp e Rhizoctonia solani (SRJUNDIAÍ 2005b).

Ocorrem diferentes tipos de viroses, como o mosqueado, que é o tipo mais comum, clorose marginal, encrespamento e faixa das nervuras (SRJUNDIAÍ 2005b).

As principais medidas de controle de doenças em cultura de morango são: evitar áreas de plantio com histórico de doença anterior, utilizar mudas sadias, eliminar as plantas com suspeita de contaminação, realizar o plantio em áreas bem drenadas e utilizar cultivares mais tolerantes às principais doenças.

A seguir estão detalhadas algumas das principais doenças da cultura do morango.

\section{- Antracnose}

Causada por fungo (Colletotrichum gloreosporioidis, C. acutatum e C. fragariaae). Existem duas formas de efeitos: a conhecida por chocolate, causada pelo fungo Colletotrichum fragariae, que pode atingir o rizoma, os frutos, os pecíolos e outras partes da planta em qualquer idade, responsável por danos causados durante o transplante, e a flor-preta (Colletotrichum acutatum), que atinge mais comumente os pedúnculos, as flores e os frutos pequenos e em desenvolvimento, produzindo necrose nos ramos florais; os frutos novos e em desenvolvimento tornam-se escuros e secos. Em frutos já desenvolvidos podem aparecer manchas marrons, profundas e firmes. A podridão é mais comum em frutos maduros, mas, em surtos severos, os verdes também são atacados (EMBRAPA 2005a; SRJUNDIAÍ 2005b).

\section{- Micosfarela ou mancha de micosfarela}

Causada pelo fungo Mycosphaerella fragariae tem ocorrência bastante generalizada em quase todas as áreas de cultivo. A doença ocasiona lesões nas folhas, estalões, pecíolos e cálices. No início, surgem pequenas manchas circulares de coloração púrpura, que, quando desenvolvidas, atingem de 3-6 mm de diâmetro, o centro torna-se marrom, evolui para cinza e finalmente branco (EMBRAPA 2005a; SRJUNDIAÍ 2005b). 


\section{- Mofo cinzento}

Causado pelo fungo Botrytis cinérea, causa podridão dos frutos e ataca também as folhas, pecíolos, caule, botões florais e pétalas. A podridão pode iniciar em qualquer ponto da superfície do fruto, mas geralmente começa no lado do fruto em contato com o solo. O tecido infectado é marrom claro, mas posteriormente desenvolve abundante massa de micélio e esporos de aspecto cotonoso (EMBRAPA 2005a).

A doença é favorecida por temperaturas amenas e alta umidade, que é o fator mais importante. Chuvas freqüentes induzem ataques severos. $O$ fungo pode sobreviver ao inverno em restos de culturas (EMBRAPA 2005a).

- Mancha angular

Doenças causadas pela bactéria Xanthomonas fragariae. Incide nas folhas causando manchas angulares, com aspecto de encharcamento, colapso dos pecíolos e morte das plantas. As condições favoráveis são temperatura de $20^{\circ} \mathrm{C}$ e alta umidade relativa do ar (EMBRAPA 2005a).

- Mosqueado

É o tipo mais comum de doença causada por vírus. O sistema de multiplicação da cultura de morango é vegetativo, permitindo a perpetuação da infecção, quando há ocorrência de afídeos eles se encarregam da transmissão dessas viroses (SRJUNDIAI 2005b).

Além das principais medidas de controle já citadas deve-se controlar os insetos vetores (pulgões) (SRJUNDIAI 2005b).

\section{- Doenças causadas por nematóides}

O Aphelenchoides besseyi é parasita da parte aérea e o Meloidogyne hapla e Pratylenchus vulnus são parasitas das raízes. Os danos causados são: lesões nas raízes e redução do sistema radicular ativo da planta que leva ao aparecimento de sintomas, como murchamento, amarelecimento, subdesenvolvimento e redução da produção. As lesões podem ainda facilitar a penetração futura de fungos de solo (SRJUNDIAI 2005b).

Para o controle recomenda-se além dos gerais, já citados, o revolvimento do solo em períodos quentes do dia (SRJUNDIAI 2005b). 


\subsection{Uso de agrotóxicos em frutas}

A agricultura brasileira destaca-se no consumo de agrotóxicos, posicionandose em $3^{\circ}$ lugar, precedida pelos Estados Unidos e Japão, e ocupa o $8^{\circ}$ lugar em relação ao volume consumido de princípio ativo por hectare $(3,2 \mathrm{~kg} / \mathrm{ha})$. Em 2000 , os gastos com agrotóxicos no Brasil foram de US\$2,50 bilhões e, de acordo com dados fornecidos pela Associação Brasileira da Indústria Química, foi de US\$ 4,2 bilhões em 2004 (SINDAG 2007a).

Tabela 16 - Consumo e custo de agrotóxicos das principais classes de princípios ativos utilizados nas culuras de frutas em relação ao total utilizado no Brasil em 2000

\begin{tabular}{|l|c|c|r|r|r|c|}
\hline Classe & \multicolumn{3}{|c|}{ Consumo } & \multicolumn{3}{c|}{ Custo } \\
\hline & $\begin{array}{c}\text { Total } \\
(1.000 \text { ton })\end{array}$ & $\begin{array}{c}\text { Frutas } \\
(1.000 \text { ton })\end{array}$ & $\begin{array}{c}\text { Frutas } \\
(\%)\end{array}$ & $\begin{array}{l}\text { Total } \\
\text { (mil US\$) }\end{array}$ & $\begin{array}{l}\text { Frutas } \\
(\text { mil US\$) }\end{array}$ & $\begin{array}{l}\text { Frutas } \\
(\%)\end{array}$ \\
\hline Acaricidas & 8.935 & 8.615 & $\mathbf{9 6}$ & 65,560 & 60,361 & $\mathbf{9 2}$ \\
\hline Fungicidas & 19.072 & 3.961 & $\mathbf{2 1}$ & 380,418 & 37,929 & $\mathbf{1 0}$ \\
\hline Herbicidas & 81.862 & 1.982 & 2 & $1.300,515$ & 20,415 & 2 \\
\hline Inseticidas & 19.447 & 1.295 & 7 & 689,953 & 19,855 & 3 \\
\hline Outros* & 11.107 & 2.203 & 20 & 63,512 & 6,176 & 10 \\
\hline
\end{tabular}

*Outros: reguladores de crescimento, antibrotantes, óleo mineral e espalhante adesivo

Fonte: Elaborada a partir de dados do SINDAG (2007a).

Verifica-se que os consumos de acaricidas e fungicidas são expressivos na fruticultura brasileira, representando $96 \%$ de acaricidas e $21 \%$ de fungicidas (Tabela 16).

Segundo Neves e col (2002), a demanda derivada de agrotóxicos (kg do princípio ativo/hectare) é maior nas frutas do que em outras culturas (soja, milho, cana-de-açúcar e café), por ex. a demanda relativa de princípio ativo foi de 48,99 $\mathrm{kg} / \mathrm{ha}$ para a maçã.

Em 2005 foram importados $128.490 .997 \mathrm{~kg} / \mathrm{L}$ de defensivos agrícolas (MAPA 2007). 
Oliveira, em 2005, fez uma revisão sobre a segurança de agentes microbiológicos para o controle de pragas e destacou as vantagens de se ter regulamentos específicos para este tipo de produto, proporcionando o uso mais fácil e seguro dos mesmos e facilitando o gerenciamento de questões relacionadas à manutenção da saúde humana e do meio ambiente (OLIVEIRA 2005b).

Muitos princípios ativos de agrotóxicos, de diferentes grupos químicos, são registrados para uso em culturas de maçã, mamão e morango, como fungicidas, inseticidas, acaricidas, herbicidas, entre outros (MAPA/AGROFIT 2005), conforme apresentado no Anexo 1.

No Anexo 1 encontram-se os ingredientes ativos de agrotóxicos registrados para uso nas culturas de maçã, mamão e morango.

Em relação aos ditiocarbamatos é autorizado o uso de mancozebe e metiram em maçã, de mancozebe em mamão e de metam sódico em morango com LMR de ditiocarbamatos $\left(\mathrm{CS}_{2}\right)$ de 3,0;2,0 e 0,2 $\mathrm{mg} / \mathrm{kg}$, respectivamente, conforme já mencionado no item 1.2.4. (Tabela 4), dentre outros alimentos vegetais (Tabelas 4,5 e 6).

\subsection{Medidas para redução dos níveis de resíduos de agrotóxicos nas frutas}

Frutas com resíduos acima dos LMR estabelecidos não são desejáveis pelos consumidores internos e externos, por representarem risco à saúde.

Além disso, o mercado mundial, consumidor de frutas in natura ou processadas, tem demandado procedimentos fitossanitários rigorosos para a aquisição desses produtos, o que tem gerado ações diferenciadas para a produção dessas no país, priorizando a qualidade, o estudo e a utilização de métodos alternativos de combate às pragas e doenças, como o manejo integrado de pragas. A minimização do uso de agrotóxicos também favorece o meio ambiente. Apesar de terem sido os motivos econômicos, ou seja, pela exigência dos países exportadores, os causadores da tomada dessas medidas, elas favorecem também os consumidores brasileiros, pois parcela da produção se destina ao mercado interno. 


\subsubsection{O uso correto e seguro de agrotóxicos}

$\mathrm{O}$ uso correto dos agrotóxicos inclue:

Adquirir produtos apenas sob receituário agronômico; usar apenas produtos fitossanitários registrados para a cultura. Usar doses recomendadas na rotulagem; respeitar os períodos de carência (intervalo de segurança); utilizar os equipamentos de proteção individual; calibrar adequadamente os equipamentos aplicadores, descartar corretamete as embalagens de agrotóxicos, de acordo com a legislação vigente (ANDEF 2003b).

Os tratamentos com agrotóxicos devem ser feitos somente com produtos registrados no Ministério da Agricultura, Pecuária e Abastecimento (MAPA) e recomendados por instituições de pesquisa, atendendo as indicações do rótulo e o prazo de carência dos produtos, na quantidade mínima exigida e somente quando tecnicamente justificado. Os equipamentos utilizados para aplicação dos agrotóxicos precisam ser seguros e eficientes e estar sempre devidamente calibrados. Além disso,

a aplicação dos produtos fitossanitários deve ser feita no momento certo, com o operador devidamente treinado e usando todos os equipamentos de proteção individual (EPI) (EMBRAPA 2005b).

O sistema de produção adotado pelo produtor deve priorizar a utilização de métodos naturais, agronômicos, biológicos e biotecnológicos de controle de pragas e doenças, minimizando o uso de produtos químicos. Assim, as Boas Práticas Agrícolas (BPA), no contexto do Manejo Integrado de Pragas (MIP), são aliadas do uso tecnificado de agrotóxicos (EMBRAPA 2005b).

\section{- Boa Prática Agrícola}

A Boa Prática Agrícola (BPA) é o conjunto de medidas adotadas pelo agricultor com o objetivo de produzir economicamente fibras e alimentos saudáveis, com qualidade e de forma a preservar a saúde humana e o meio ambiente. A boa prática agrícola é considerada um dos alicerces da agricultura sustentável, pois através dela os agricultores podem preservar os recursos naturais para as gerações futuras. Exemplos de práticas importantes são o manejo e conservação de solo para evitar erosões; manejo integrado de pragas, manejo integrado de culturas, 
preservação das matas ciliares, preservação dos recursos hídricos e uso correto e seguro de agrotóxicos (ANDEF 2003b).

\section{- Manejo Integrado de Pragas (MIP)}

É definido pelo Código Internacional de Conduta, Distribuição e Uso de Pesticidas da FAO/WHO como um sistema de gerenciamento que, num contexto associado de meio ambiente e de dinâmica de pragas, utiliza todas as técnicas e métodos disponíveis de forma compatível e possível para manter as concentrações das populações de pragas abaixo daquelas que possam resultar em níveis inaceitáveis de danos ou perdas nas culturas (ANDEF 2003b).

Os produtores devem conservar os recursos naturais do solo, água, matas nativas e vida selvagem no entorno de sua plantação ou pomar, que não devem ser alterados de modo danoso, eliminados ou contaminados. As diversidades de espécies vegetais, animais e microorganismos do solo favorecem o equilíbrio ecológico, minimizando a necessidade de agrotóxicos e o emprego de fertilizantes químicos. Desta forma, os riscos e os níveis de poluição decorrentes, nas águas superficiais e subterrâneas, especialmente de nitratos e herbicidas, serão minimizados ou eliminados.

\subsubsection{Produção Integrada de Frutas no Brasil}

O cenário internacional sinaliza que é cada vez mais valorizado o aspecto qualitativo e o respeito ao meio ambiente, na produção de qualquer produto. Para tanto, são necessários o aperfeiçoamento dos mercados, a mudança de hábitos e a produção de alimentos seguros. Normas européias têm pressionado exportadores de frutas e hortaliças para o estabelecimento de regras de produção que levem em consideração os resíduos de agroquímicos, o meio ambiente e as condições de trabalho e higiene (EMBRAPA 2005c).

No Brasil, o MAPA tem dado apoio contínuo, com o objetivo principal de elevar os padrões de qualidade e competividade da fruticultura brasileira, com bases voltadas para o sistema integrado de produção, sustentabilidade do processo, expansão da produção e emprego e renda (EMBRAPA 2005c). 
Na América do Sul, a Argentina foi a primeira a implantar o PIF, em 1997, e, no mesmo ano, o Uruguai e o Chile também adotaram o sistema. No Brasil, as atividades foram iniciadas em 1998. É um sistema de produção orientada e de livre adesão por parte dos produtores e empacotadores (EMBRAPA 2005c).

O PIF apresenta quatro pilares de sustentação: organização da base produtiva, sustentabilidade, monitoramento do sistema de informação e dos componentes que consolidam o processo: manejo integrado de pragas, de nutrientes, de solo e de água, da cultura, da colheita e pós-colheita e monitoramento do sistema e ambiental, com sustentabilidade. O MAPA fechou parceria com o Instituto Nacional de Metrologia, Normalização e Qualidade Industrial (INMETRO) para implantar o sistema informatizado para cadastro nacional, o regulamento de avaliação de conformidade, os organismos de avaliação de conformidade e o selo de conformidade (EMBRAPA 2005c).

Os selos de conformidade, contendo códigos numéricos, são colocados nas embalagens, possibilitando a qualquer pessoa obter informações sobre procedência dos produtos, procedimentos técnicos operacionais adotados, produtos utilizados no processo produtivo, dando transparência ao sistema e maior confiabilidade ao consumidor. As frutas podem ser identificadas desde a fonte de produção até o seu destino final (EMBRAPA 2005c).

As normas técnicas específicas para maçã, uva de mesa, manga, mamão, caju e melão já foram concluídas e publicadas pelo MAPA.

$\mathrm{Na}$ Produção Integrada de Maçã (PIM) são preconizadas ações que visam a conservar os inimigos naturais das pragas, entre elas o uso de agrotóxicos seletivos. Segundo Kovaleski e col. (2000), é provável que após algumas safras com menor volume de aplicações de agrotóxicos, as áreas de PIM venham a exibir maiores populações de organismos benéficos, e que seja favorecido o controle biológico natural.

\section{- Benefícios da Produção Integrada de Frutas (PIF) no Brasil}

O PIF proporciona aos consumidores a garantia de frutas de alta qualidade; índice de resíduos de acordo com padrões brasileiros e internacionais e sustentabilidade do processo de produção (EMBRAPA 2005c). 
Em 2002, a diminuição da freqüência de aplicação do ditiocarbamato em 8,660ha de cultura de maçã com redução de $600 \mathrm{t}$, ao custo de $\mathrm{R} \$ 15,00 \mathrm{~kg}$, representou a economia de $\mathrm{R} \$ 9,0$ milhões, sem considerar os efeitos relacionados a preservação de recursos naturais, como ar, água, solo e biodiversidade (EMBRAPA 2005c).

Dias (2005), coordenador da pesquisa realizada no Norte de Minas Gerais "Estudo de cultivares em morangueiro em sistema orgânico de produção", afirma que as variedades estudadas são as destinadas tanto para o consumo in natura como para produção de polpa e são bastante suscetíveis a pragas e doenças típicas, como os fungos Colletotrichum acutatum e Colletotrichum fragarie, que necessitam de baixa temperatura e alta umidade para se desenvolverem. O estudo apresentou um resultado interessante: a pequena incidência de doenças nas plantações na região, conhecida pelas elevadas temperaturas, levando à alta produção sem uso de agrotóxicos. Este estudo teve por objetivo avaliar o comportamento de cultivares, definir o método mais eficiente de irrigação para o sistema e testar produtos naturais no combate a pragas e doenças. Um desses produtos é o Nim, vegetal de origem indiana com propriedades fungicidas. Outras formas de combate, como os quebraventos, que impedem a disseminação de esporos pelo ar e as barreiras naturais. Outro dado promissor é que enquanto no sul do país o pico de produção acontece nos meses de agosto e setembro, no norte do Estado de Minas Gerais ocorre entre os meses de setembro e outubro, abrindo uma valiosa possibilidade comercial.

$\mathrm{O}$ cultivo de morangueiros em sistemas hidropônicos abre algumas possibilidades para combinar o cultivo em ambientes protegidos com a eliminação do uso de produtos destinados à desinfecção do solo. Entretanto, é necessário que o real potencial das técnicas de cultivo sem solo seja avaliado no que diz respeito à produtividade e ao manejo fitotécnico. É importante, também, que se gerem e se adaptem técnicas de cultivo hidropônico do morangueiro para as condições tropicais e subtropicais (FURLANI e FERNANDES 1999). 


\subsection{Principais estudos de monitoramento de resíduos de agrotóxicos em alimentos}

Amostras de frutas e vegetais foram analisadas pelo United States Department of Agriculture (USDA), em 2003, e 200 dessas estavam em desacordo com a legislação. Destas, 35 apresentaram resíduos acima do LMR permitido, 170 continham 1 resíduo de agrotóxico e 13 com 2 resíduos de agrotóxicos com tolerância não estabelecida, sendo que 5 dentre essas estavam insatisfatórias pelos dois motivos.

Diversos países têm implantado programas de análise de resíduos nos alimentos. Nos Estados Unidos, numerosos programas de análises de resíduos têm sido implantados, podendo-se destacar o programa do Departamento de Agricultura dos Estados Unidos (USDA), o programa da Associação Nacional dos Alimentos Processados (NFPA) e o programa da Administração de Drogas e Alimentos (FDA). O último relatório da FDA, referente ao ano de 2002, analisou 6.766 amostras de leite, grãos, carnes, ovos, frutas e outros vegetais, produzidos no mercado interno e amostras importadas (FDA, 2002). Dos grupos de amostras analisadas vindas do mercado interno, todos continham resíduos de agrotóxicos, porém apenas os grupos de amostras de origem vegetal (grãos, frutas e vegetais) continham resíduos de agrotóxicos acima do nível tolerado. Já as amostras vindas do mercado externo apresentaram índices de contaminação acima do tolerado em amostras do grupo de vegetais e também em amostras de origem animal (peixe).

No ano de 2002, na União Européia, foram analisadas 4.600 amostras, em 15 países membros, quanto à presença de 170 tipos de agrotóxicos. Os resultados obtidos mostraram que $54 \%$ das amostras estavam livres de agrotóxicos, enquanto $37 \%$ apresentaram níveis residuais abaixo do limite tolerável. Cerca de $6 \%$ das amostras acusaram a presença de resíduos de agrotóxicos acima do nível permitido, sendo a maior incidência em frutas e verduras. O nível de resíduos detectados no último ano foi o maior se comparado com os índices de contaminação dos seis anos anteriores. Cerca de $21 \%$ das amostras contaminadas continham mais de um tipo de agrotóxico (EUROPEAN COMMISSION 2004; STOPELLI 2005).

No Brasil, no Programa de Análise de Resíduos de Agrotóxicos em Alimentos (PARA), foram analisadas 4.345 amostras, sendo 487 de alface, 418 de 
banana, 555 de batata, 452 de cenoura, 531 de laranja, 395 de maçã, 474 de mamão, 474 de morango e 564 de tomate, no período compreendido entre junho de 2001 e dezembro de 2004, em redes de supermercados das cidades de Belém, Belo Horizonte, Campo Grande, Curitiba, Florianópolis, Goiânia, Palmas, Porto Alegre, Recife, Rio de Janeiro, Rio Branco, São Paulo e Vitória. 931 (28\%) delas apresentaram resultados em desacordo com a legislação vigente, sendo que, dessas, $776(83 \%)$ apresentaram resíduos de uso não autorizado para a cultura e $17 \%$ com concentrações acima dos LMR (ANVISA 2005)

Foram analisadas 125 amostras de hortifrutícolas, de setembro de 2003 a fevereiro de 2004, no Subprograma de Resíduos de Agrotóxicos do Programa Paulista de Análise Fiscal de Alimentos Biênio 2003-2004 (PP0304), sendo que 30 (24\%) dessas foram consideradas insatisfatórias, 28 (22\%) por apresentarem resíduos acima do LMR e 18 (14\%) por conterem agrotóxicos de uso indevido para a cultura (SÃO PAULO 2005).

No período de janeiro de 1994 a abril de 2005 foram monitoradas, em relação a resíduos de agrotóxicos, 3.082 amostras de 52 produtos hortifrutícolas originários de centenas de municípios brasileiros e comercializados na CEAGESP. Os resultados desses 11 anos revelaram a ausência de resíduos de agrotóxicos em cerca de $70 \%$ das frutas e hortaliças analisadas. Nas 916 amostras que, representam os $30 \%$ restantes, foram detectadas 1.068 ocorrências de resíduos, das quais $50 \%$ estavam abaixo da tolerância, 4\% acima e $45 \%$ delas continham agrotóxicos não registrados para as culturas nas quais foram detectados resíduos (GOREINSTEIN e GUTIERREZ 2006).

Looser e col. (2006) avaliaram 593 amostras de morango comercializadas no Estado de Banden-Württemberg, na Alemanha. Foram encontrados resíduos de pesticidas em 98\% das frutas originárias da Alemanha, Espanha, Itália e Marrocos, sendo que 93\% delas continham múltiplos resíduos de pesticidas na mesma amostra. Os LMR da Alemanha ou da União Européia harmonizados foram excedidos em $9 \%$ das amostras de morango. A soma da concentração de todos os pesticidas encontrados por amostra foi em média $0,41 \mathrm{~m} / \mathrm{kg}$, sendo que os produtos da Itália continham as mais altas e os da Alemanha as mais baixas concentrações. Fungicidas foram mais freqüentemente detectados do que inseticidas e herbicidas. Os compostos 
mais detectados foram: ciprodinila, fludioxonila, fenhexamida, tolifluanida e azoxistrobina, responsáveis por mais de $50 \%$ do total das detecções.

Kautter (2006) avaliou oito produtos: pêra, uva, pêssego, nectarina, alface, tomate, pepino e pimentão, num total de 658 amostras compradas em supermercados da Alemanha, Áustria e Suíça. Foram pesquisados 300 princípios ativos e foram encontrados 113, sendo que 10 deles foram responsáveis por $66 \%$ dos valores em excesso. Foram encontradas em média 3,5 substâncias por amostra. A dose de referência aguda (ARfD), definida pelo Federal Institute for Risk Assessment (BfR) e WHO para crianças de 2 a 5 anos $(16,15 \mathrm{~kg}$ de peso corpóreo), foi também examinada com base na quantidade de consumo publicada pelo BfR. A ARfD foi excedida de 3,5 a 7 vezes, dependendo do produto, em 4\% das amostras. Contudo, em 17 dos valores que excederam a $\mathrm{ARfD}$, os LMR não foram excedidos. Isto ilustra que a $\mathrm{ARfD}$ e, conseqüentemente, o potencial de risco de efeito agudo adverso à saúde, causado pela ingestão de resíduos de agrotóxicos, não tem sido freqüentemente levado em conta no estabelecimento dos LMR.

Araújo e col., no período de outubro de 1999 a março de 2001 , participaram de um programa de certificação da qualidade nas frutas exportadas do vale do São Francisco, onde foram analisadas 383 amostras, sendo 232 de uva e 151 de manga. Foram encontrados resíduos de agrotóxicos em 24\% dessas, porém apenas 3,9\% apresentaram resíduos estavam acima dos LMR estabelecidos pelas legislações dos países importadores (ARAÚJO 2001).

\subsubsection{Principais estudos de resíduos de ditiocarbamatos em frutas}

De 196 amostras de morango analisadas na Holanda, em 1998, 179 (91 \%) apresentaram resíduos de ditiocarbamatos em níveis que variaram de 0,1 a 0,6 $\mathrm{mg} / \mathrm{kg}$, porém, todas dentro do LMR permitido, que é de $3 \mathrm{mg} / \mathrm{kg}$; 9 amostras de laranja não apresentaram resíduos de ditiocarbamatos no LD de $0,05 \mathrm{mg} / \mathrm{kg}$ e de 22 amostras de uva, 15 (68\%) tinham resíduos em concentrações que variaram de 0,2 a 0,4 mg/kg, porém, abaixo do LMR, que é de $3 \mathrm{mg} / \mathrm{kg}$ (DE KOK 1999).

Segundo dados obtidos por um laboratório na Holanda, foram encontrados ditiocarbamatos acima do LMR em 5 (100 \%) amostras de mamão Papaya Carica L. originário do Brasil, em níveis que variaram de 0,3 a 0,6 mg/kg, em 1 amostra de uva 
na concentração de 0,6 mg/kg e em 1 amostra de "kumquat" (pequena laranja) na concentração de 0,4 mg/kg, no período de 1995 a 1998. Em amostras originárias do Chile foram encontrados ditiocarbamatos em 3 amostras de framboesa e em 1 amostra de amora, na concentração de $0,1 \mathrm{mg} / \mathrm{kg}$ cada. Nas amostras originárias da Argentina não foram encontrados ditiocarbamatos (DE KOK 1999).

Maçãs, alfaces e batatas, dentre as 404 amostras pesquisadas na Eslovênia, foram analisadas para resíduos de agrotóxicos (período de 2001 a 2004) e, dois ou mais princípios ativos foram encontrados em 73 amostras de maçã (48\%), das quais apenas $3(2 \%)$ excederam o LMR, com valores que variaram de 0,3 a $2,0 \mathrm{mg} / \mathrm{kg}$ (fosalona e tolilfluanida). Resíduos de ditiocarbamatos foram os mais freqüentemente encontrados, ou seja, em 66 (44\%) amostras de maçã, em 30 (31\%) das amostras de alface e em 38 (24\%) das amostras de batata (CESNIK 2006).

Em Belo Horizonte-MG, resíduos de ditiocarbamatos foram determinados em 87 amostras de frutas e 11 de hortaliças. Foi constatada a presença de ditiocarbamatos em $\mathrm{CS}_{2}$ em 24 (48\%) das 98 amostras, tendo sido mais freqüente em frutas como pêssego (100\%), ameixa (60\%), nectarina $(50 \%)$ e morango $(37 \%)$ (PEREIRA 1988).

Oliveira e Toledo (1995) estudaram resíduos de agrotóxicos em amostras de morango coletadas na Companhia de Entrepostos e Armazéns Gerais Sociedade Anômina (CEASA) de Campinas, sendo que 27\% apresentaram endosulfam e clorotalonil, proibidos pela legislação, e 23\% resíduos de captana dentro do LMR estabelecido. Não foram detectados níveis de mancozebe no limite de quantificação do método $(0,5 \mathrm{mg} / \mathrm{kg})$.

No Programa Nacional de Análise de Resíduos de Agrotóxicos em Alimentos - PARA (período de 2001-2002) foram encontrados resíduos de ditiocarbamatos, em 68 (69\%) das 99 amostras de maçã, em níveis que variaram de 0,04 a 2,10 mg/kg; em 58 (40\%) das 144 amostras de mamão, de 0,10 a 2,14 mg/kg); em 85 (60\%) das 141 amostras de morango, de 0,10 a 1,03 mg/kg; em 1 (1\%) das 92 amostras de banana $(0,01)$ e em $1(1 \%)$ das 141 amostras de laranja. Foram também encontrados resíduos de ditiocarbamatos em 100 (52\%) das 189 amostras de tomate, em níveis que variaram de 0,07 a $1,50 \mathrm{mg} / \mathrm{kg}$; em 57 (35\%) das 162 amostras de alface, em níveis que variaram de 0,10 a $3,50 \mathrm{mg} / \mathrm{kg}$; e em nenhuma das 176 
amostras de batata e em nenhuma das 134 amostras de cenoura (ANVISA 2003). Em 2003 foram encontrados resíduos de ditiocarbamatos em 35 (32\%) das 109 amostras de maçã, em níveis que variaram de 0,08 a 1,48 mg/kg; em 30 (21\%) das 143 amostras de mamão, de 0,09 a 1,2 mg/kg); em 25 (17\%) das 143 amostras de morango, de 0,09 a 1,10 mg/kg. Em 2004 foram encontrados resíduos de ditiocarbamatos, em 135 (84\%) das 161 amostras de maçã, em níveis que variaram de 0,2 a 2,0 mg/kg; em $124(77,5 \%)$ das 160 amostras de mamão, de 0,2 a 3,97 $\mathrm{mg} / \mathrm{kg}$ ) e em $9(6 \%)$ das 151 amostras de morango, de 0,1 a $1,4 \mathrm{mg} / \mathrm{kg}$ (ANVISA 2005).

Caldas e col. (2004) analisaram resíduos de ditiocarbamatos (em $\left.\mathrm{CS}_{2}\right)$ em amostras de alimentos coletadas em supermercados do Distrito Federal entre 1999 e 2000 e encontraram níveis de até $1,9 \mathrm{mg} / \mathrm{kg}$ em 37(95\%) das amostras de maçã; 1,3 $\mathrm{mg} / \mathrm{kg}$ em 38 (50\%) das amostras de polpa de banana; 1,2 mg/kg em 33 (58\%) das amostras de laranja; $1,9 \mathrm{mg} / \mathrm{kg}$ em 35 (63\%) das amostras de polpa de mamão+semente e de até $3,8 \mathrm{mg} / \mathrm{kg}$ em 47 (55\%) das amostras de morango.

No Programa Paulista de Análise Fiscal de Alimentos (PP0304) foram encontrados ditiocarbamatos em 13(54\%) amostras de morango e em 4(13\%) de pimentão ( SÃO PAULO 2005).

\subsubsection{Alguns estudos de ditiocarbamatos em outros vegetais (exceto frutas)}

Rodriguez e Lamoth (1994) analisaram 229 amostras de alimentos cultivados no Panamá e $22 \%$ das amostras continham resíduos de agrotóxicos, sendo que, destas, 10\% apresentaram níveis em desacordo com normas internacionais, incluindo os ditiocarbamatos.

Bolanos e col. (1997) estudaram os níveis de resíduos de agrotóxicos em Cuba (no período de 1990 a 1995) e encontraram níveis de ditiocarbamatos em amostras de tomate, cebola, batata (papa), com níveis de até 7,2;6,5;5,0 mg/kg, respectivamente. Em 13\% das 216 amostras de batata analisadas, o LMR foi excedido. Alertaram sobre a necessidade de limitações de uso dos mesmos, principalmente por motivos relacionados à saúde humana. 
Hanborg e col. (2006) monitoraram resíduos de agrotóxicos em 6.956 amostras de frutas e vegetais comercializadas no período de 1998 - 2003, e em 7\% delas foram encontrados ditiocarbamatos. Desse modo, os ditiocarbamatos ficaram entre os seis ativos que mais contribuíram para a ingestão diária de resíduos de agrotóxicos no estudo.

No Brasil, um trabalho realizado no Estado de Minas Gerais, mostra que 19\% das hortaliças e 17\% das frutas analisadas apresentaram resíduos de ditocarbamatos em níveis de até $1,7 \mathrm{mg} / \mathrm{kg}$ (SOARES e col. 1987).

Reis e Caldas (1991) estudaram resíduos de ditiocarbamatos em 466 amostras de vegetais e frutas comercializadas na cidade do Rio de Janeiro. Observou-se que $63 \%$ das amostras apresentaram resíduos de ditiocarbamatos, sendo que $24 \%$ delas com concentrações superiores ao limite máximo permitido por lei. Alface, cenoura e tomate foram os produtos que apresentaram os maiores níveis de resíduos, com 50\%, $47 \%$ e $38 \%$ das amostras acima do LMR, respectivamente.

Conceição (2002) analisou resíduos de ditiocarbamatos em 80 amostras de tomate do Distrito Federal e 59\% apresentaram resíduos em níveis que variaram de 0,2 a $1,2 \mathrm{mg} / \mathrm{kg}$ de $\mathrm{CS}_{2}$.

\subsubsection{Estudos de resíduos de ETU em alimentos}

Encontram-se na literatura internacional alguns trabalhos de análise de resíduos de ETU em alimento in natura, desde a década de 70 . Em várias amostras de maçã foram encontrados níveis de ETU que variaram de 0,018 a 0,044 ppm (NEWSOME 1972), Onley e col. (1977) reportaram que de 6 maçãs comerciais, somente uma apresentou resíduos de EBDC, contendo 0,01 ppm de ETU. Ripley e Cox (1978) detectaram ETU em níveis abaixo de 0,05 ppm em tomates e acima de 0,17 ppm em suco de tomates.

DUBEY e col. 1997 monitoraram amostras do comércio para determinação de ditiocarbamatos e ETU e em 4 (20\%) das 20 amostras positivas para ditiocarbamatos ( 0,20 a 0,80 ppm) foram encontrados resíduos de ETU em níveis que variaram de 0,01 a 0,37 ppm. Dessas 3 amostras eram de pêra (0,05 a 0,20 ppm).

Em estudo realizado na Itália, por Aprea e col., em 1997, foram encontrados 8,8 $\mu \mathrm{g}$ de ETU/Litro de vinho. Para frutas e vegetais a concentração de ETU estava 
abaixo do limite de detecção $(3-20 \mu \mathrm{g} / \mathrm{kg})$, com exceção de uma amostra composta por massa com brócolis, mistura de vegetais, pêra e água (almoço), que apresentou $3 \mu \mathrm{g} / \mathrm{kg}$.

Blasco e col. (2004) estudaram método para determinação de ditiocarbamatos e metabólitos em plantas por cromatografia líquida - espectrometria de massa (modo SIM), o qual foi utilizado para determinação de resíduos de fungicidas em 10 amostras de vegetais adquiridas em diferentes supermercados de Valência, Espanha, sendo que ETU foi detectada em duas amostras de arroz em níveis de até 0,32 mg/kg. e em uma de tomate $(0,36 \mathrm{mg} / \mathrm{kg})$.

Araujo, em 1998, analisou amostras de tomate, sendo a ETU detectada em 25 (78\%) das 32 amostras de tomate de mesa e em 15 (55\%) das 27 amostras de tomate industrial. Porém, $3(11 \%)$ das amostras de tomate industrial e apenas $1(3 \%)$ apresentou resultado acima do limite de quantificação do método proposto, que foi de $0,025 \mathrm{mg} / \mathrm{kg}$.

\subsection{Estimativas para avaliar o risco de exposição pela ingestão de alimentos com resíduos de agrotóxicos}

Para concluir a respeito do risco de exposição a agrotóxicos pela ingestão de alimentos, do ponto de vista de saúde pública, é necessário estimar a ingestão de resíduos de um agrotóxico e compará-la com a Ingestão Diária Aceitável (IDA) estabelecida.

\section{- Ingestão de resíduo de agrotóxico}

A ingestão de resíduo de agrotóxico de um determinado alimento é obtida multiplicando-se o nível de resíduos no alimento pela quantidade consumida daquele alimento. Os valores disponíveis de resíduos são combinados com as informações da ingestão dos alimentos, para se obter um prognóstico da ingestão dos resíduos pelos consumidores. A ingestão diária total de resíduo de agrotóxico é obtida somando-se as ingestões de todos os alimentos contendo o resíduo. A exposição ao resíduo de agrotóxico presente, ou provavelmente presente, em água potável, ou em alimento para o qual não foi estabelecido o LMR, deve ser levada em consideração, quando tal informação estiver disponível. A ingestão diária estimada dos resíduos de agrotóxicos resultante da aplicação de um agrotóxico ou de outras fontes deve ser 
menor do que a sua IDA estabelecida ou dose aguda de referência (GEMS/FOOD 1997).

\subsubsection{Estimativas da ingestão diária de agrotóxicos a longo prazo (ou crônica)}

O JMPR procura prever a ingestão de resíduos de agrotóxicos com base nos dados disponíveis. Em nível internacional, a Ingestão Diária Máxima Teórica (TMDI) é usada como uma ferramenta para avaliar a ingestão diária de resíduos de agrotóxicos. A Ingestão Diária Máxima Teórica em nível nacional pode ser usada para propósitos similares. Os dados em nível nacional podem ser mais precisos e culturalmente relevantes, como no caso das porções comestíveis, processamento e práticas de cocção.

- Ingestão Diária Máxima Teórica (Theorical Maximum Daily IntakeTMDI)

Tomando-se o LMR como limite de resíduo e utilizando os padrões de dieta para a quantidade de alimento consumido, chega-se à Ingestão Diária Máxima Teórica (Theorical Maximum Daily Intake-TMDI) (GEMS/FOOD 1997).

A TMDI é uma superestimativa da ingestão real de resíduos de agrotóxicos, principalmente porque o LMR se aplica ao vegetal inteiro e in natura, que quase sempre inclui uma porção não comestível, como por ex. a casca. Porém, se a TMDI não exceder a IDA, é altamente improvável que seja excedida na prática, desde que os LMR sejam estabelecidos para os principais usos do agrotóxico e de que sejam utilizadas as Boas Práticas Agrícolas. Neste caso, não são necessárias estimativas mais precisas para a ingestão de resíduos (GEMS/FOOD 1997).

\section{- TMDI utilizada no Reino Unido pelo Pesticide Safety Directorate (PSD)}

A estimativa da ingestão de agrotóxicos pelo PSD considera que a utilização do dado de maior consumo é melhor do que o de consumo médio, para proteger toda a população. O PSD utiliza 97,5\% para definir o maior consumo (PSD 2004).

O PSD utiliza os pesos médios dos consumidores das pesquisas de consumo como padrão nos cálculos da ingestão aguda e crônica de 70,1 kg para adultos (16 a 64 aos), de 43,6 kg para estudantes (10 a 15 anos), de 14,5 $\mathrm{kg}$ para crianças ( $1 \frac{1}{2}$ a 4 $1 / 2$ anos) e de $8,7 \mathrm{~kg}$ para bebês (6 a 12 meses) (PSD 2004). 
Quando há informação disponível, a Ingestão Diária Estimada Internacional (International Estimated Daily Intake - IEDI). É usada para se obter melhor estimativa da ingestão diária crônica de resíduos de agrotóxicos, com base na mediana dos resíduos provenientes dos campos supervisionados, considerando o resíduo existente nas partes comestíveis, os componentes definidos como resíduos pelo JMPR (princípio ativo, metabólitos e produtos de degradação de importância toxicológica) e as alterações dos resíduos provenientes do preparo, cozimento ou processamento industrial (GEMS/FOOD 1997). Quando disponíveis, podem ser usados dados sobre monitoramento, vigilância ou estudos de dieta total (GEMS/FOOD 1997).

- Ingestão Diária Máxima Estimada (Maximum Estimated Daily Intake MEDI)

A Ingestão Diária Máxima Estimada (MEDI) é uma estimativa mais realista da ingestão de resíduos. É calculada usando dados da porção comestível do vegetal e leva em consideração os efeitos na preparação, no processamento e no cozimento do alimento. $\mathrm{O}$ consumo médio de alimentos pode ser derivado de uma dieta hipotética mundial ou nacional. Quando a MEDI exceder a IDA é necessário refinar o cálculo para estimar a verdadeira ingestão (GEMS/FOOD/WHO 1997).

- Ingestão Diária Estimada Nacional (National Estimated Daily IntakeNEDI)

O cálculo da NEDI leva em consideração fatores como: os dados de consumo alimentar, inclusive os correspondentes a subgrupos da população; os usos conhecidos do agrotóxico em questão; os níveis de resíduos conhecidos; a porcentagem da cultura que foi tratada; a relação entre a quantidade do produto de origem nacional e a quantidade importada; a redução ou aumento do nível de resíduo durante o armazenamento, o processamento e o cozimento. As estimativas da NEDI só podem ser feitas no âmbito nacional, quando essas informações estiverem disponíveis (GEMS/FOOD/WHO 1997).

A caracterização do risco para ambos os casos é baseada em um adulto médio com valor do peso corpóreo de $60 \mathrm{~kg}$, adotado pelo JMPR para a população em geral, e é expressa em mg de resíduo por kg de peso corpóreo. O valor do peso corpóreo 
para crianças com idade de até 6 anos, adotado pelo JMPR, é de $15 \mathrm{~kg}$ (GEMS/FOOD/WHO 1997).

- Fatores para o refinamento das estimativas dos níveis de resíduos para a previsão da ingestão diária

Os principais fatores para o refinamento das estimativas dos níveis de resíduos para a previsão da ingestão diária em longo prazo dos agrotóxicos em nível nacional são: níveis de resíduos medianos dos experimentos supervisionados, incluindo a definição de resíduos; resíduos em porções comestíveis; efeitos do processamento e cozimento nos níveis de resíduos; outras utilizações conhecidas do agrotóxico; proporção da colheita ou produto produzido domesticamente e importado; dados do monitoramento e da fiscalização; estudos da dieta total (cesta de mercado); dados sobre o consumo alimentar, incluindo os subgrupos da população.

Para estimativas mais refinadas, deve-se levar em conta os resíduos após o processamento. Geralmente há informação disponível sobre a conversão de um composto para um metabólito ou produto de degradação durante o processamento. As estimativas da ingestão diária podem ser feitas em nível nacional, com base na informação sobre o consumo dos produtos processados, porém esta abordagem só é útil quando existe uma IDA para a substância em questão (GEMS/FOOD/WHO 1997).

No projeto de estudo de avaliação do risco, para todas as estimativas, deve ser considerado o potencial para a produção de metabólito ou produtos de degradação de interesse toxicológico. Os LMR geralmente não são estabelecidos para tais substâncias, mas as IDA separadas devem ser estabelecidas para metabólitos e produtos de degradação potencialmente tóxicos (GEMS/FOOD/WHO 1997). A etilenotiouréia pode ser produzida ou persistir em alimentos processados tratados ou contaminados por EBDC, conforme já mencionado, e principalmente por ser potencialmente tóxica, apresenta a IDA para ETU, estabelecida pela FAO/WHO (1994). 


\subsubsection{Estimativa da ingestão diária a curto prazo (ou aguda)}

Quando determinado agrotóxico possuí efeitos tóxicos agudos, deve-se considerar a quantidade máxima que pode ocorrer em um dado alimento a ser consumido durante um curto período. O PSD estima a ingestão diária aguda para os agrotóxicos (PSD 2004).

- Estimativa da ingestão diária a curto prazo (ou aguda) NESTI (National Estimates of Short-Term Intake)

A estimativa da ingestão diária a curto prazo (ou aguda) é chamada de NESTI (National Estimates of Short-Term Intake). É calculada multiplicando-se o dado de consumo para uma unidade do alimento com o maior nível de resíduo detectado no alimento ou na parte comestível, dividido pelo peso corpóreo médio (PSD 2004).

Os fatores que devem ser considerados para refinar a estimativa da ingestão aguda diária são: efeitos nos limites de resíduo devido ao armazenamento, processamento ou preparo; dados de resíduo na parte comestível; resíduos que se encontram no Limite de Quantificação (LQ) ou inferiores; dados de consumo alimentar incluindo os subgrupos populacionais; considerar como resíduo os metabólitos e produtos de transformação de importância toxicológica (PEREIRA 2005). 


\section{OBJETIVOS}

\subsection{Objetivo Geral}

Avaliar os níveis de resíduos de etilenotiouréia em frutas comercializadas na cidade de São Paulo.

\subsection{Objetivos específicos}

- Validar método analítico por HPLC-UV e LC/MS/MS para determinação de resíduos de etilenotiouréia em maçã, mamão e morango;

- Verificar a presença de resíduos de etilenotiouréia (ETU) em amostras de frutas (mamão, maçã e morango), comercializadas na cidade de São Paulo, amostradas de forma a representar as quatro estações do ano e as cinco regiões do município;

- Avaliar os resultados e a contribuição de risco à saúde da população consumidora. 


\section{METODOLOGIA}

Foi realizado estudo de caso analítico, no qual a hipótese é a presença de resíduos de etilenotiouréia em frutas comercializadas na cidade de São Paulo.

A parte experimental analítica foi realizada no Laboratório de Resíduos de Pesticidas da Diretoria do Serviço de Química Aplicada da Divisão de Bromatologia e Química do Instituto Adolfo Lutz - Central.

\subsection{Matriz de estudo - Frutas}

A escolha por trabalhar com frutas deveu-se ao fato de serem ingeridas in natura, pelo seu expressivo consumo na dieta do brasileiro e por existir a possibilidade de conter resíduos de etilenotiouréia, pois os etilenobisditiocarbamatos são autorizados para uso em, praticamente, todas as frutas.

\subsubsection{Critérios para escolha das frutas}

- Frutas de maior consumo pela população da cidade de São Paulo;

- Possibilidade de apresentarem resíduos de ETU: autorização de uso de EBDC;

- Presença de resíduos de ditiocarbamatos em estudos anteriores;

- Hábitos no consumo das frutas, principalmente a ingestão com casca;

- Consumo por subgrupos de interesse para avaliação de risco à saúde, como crianças, mulheres grávidas e pessoas que só consomem vegetais (vegetarianos).

Os critérios descritos acima foram considerados em conjunto para a escolha das matrizes de estudo e as informações foram detalhadas no item 1.10.2.

\subsubsection{Planejamento da amostragem}

O método de amostragem utilizado foi aleatório. Os locais de compra foram escolhidos ao acaso de forma a representar o consumo nas cinco regiões da cidade de São Paulo (Norte, Sul, Leste, Oeste e Centro). As frutas foram adquiridas pela autora em supermercados durante o período de 21/12/2005 a 19/12/2006, em datas planejadas de maneira que representassem as diferentes estações do ano, levando em 
conta a época das frutas em estudo.

As variedades de maçã amostradas foram gala (14), fuji (13) e red (3), adquiridas de acordo com a disponibilidade e menor preço.

\section{- Coleta das amostras}

Foram adquiridas amostras de mamão e maçã compostas por 12 frutos cada, de acordo com a recomendação do Codex Alimentarius (TOLEDO e col. 2002 p. 70), com variação de massa de 2,5 a 4,8 kg para o mamão e de 1,0 a 2,3 kg para a maçã. As 24 redes de supermercados onde foram adquiridas as amostras encontram- se relacionadas no Anexo 2.

O morango é, freqüentemente, vendido em bandejas com peso aproximado de 300 ou $350 \mathrm{~g}$. Foram adquiridas 3 bandejas, com peso médio de 0,321 kg cada, onde todos os frutos foram inclusos para compor cada amostra..

As amostras foram embaladas em saco de polietileno, devidamente identificadas e transportadas.

\section{- Locais de coleta das amostras}

Noventa amostras foram adquiridas em trinta e cinco diferentes bairros da Cidade de São Paulo, assim distribuídos, de acordo com as respectivas regiões: Norte: Jardim São Paulo, Parada Inglesa, Vila Maria, Santana, Tucuruvi, Vila Guilherme; Sul: Vila Mariana, Jabaquara, Jaçanã, Mirandópolis, Vila Clementino, Santo Amaro, Saúde; Leste: Aricanduva, Belém, Itaquera, Parque do Carmo, Penha, São Mateus, Vila Carrão, Vila Matilde, Tatuapé; Oeste: Alto de Pinheiros, Barra Funda, Butantã, Cerqueira Cesar, Jardim Paulista (Jardim América), Perdizes, Pinheiros, Vila Pompéia e Centro: Bela Vista, Bom Retiro, Consolação, Liberdade, Santa Cecília (Figura 15). 


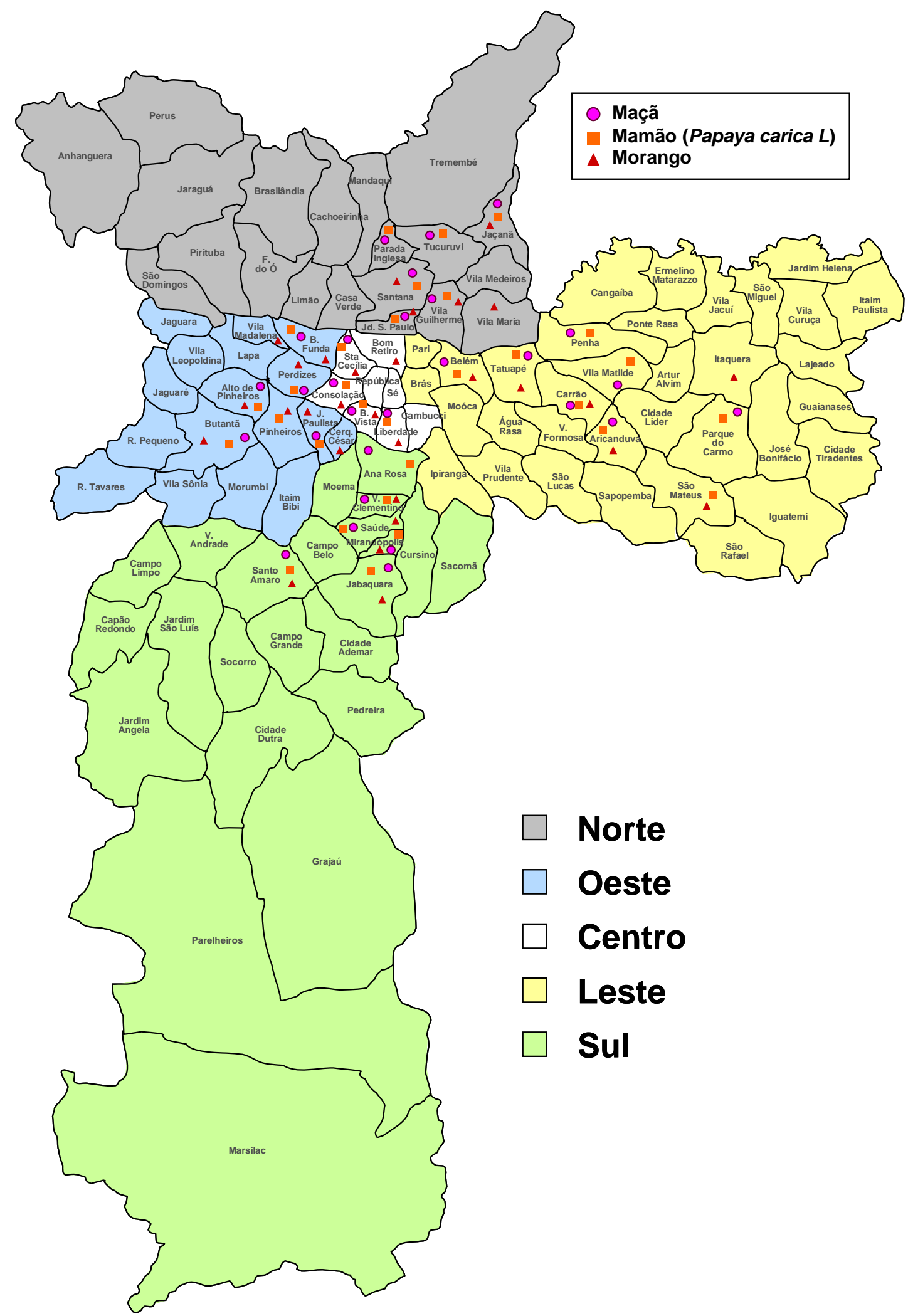

Figura 15 - Distribuição dos locais de amostragem de acordo com o bairro da cidade de São Paulo, no período de 21/12/2005 a 19/12/2006 


\section{- Número de amostras}

Para avaliação dos níveis de ETU em frutas, foram compradas 30 amostras de cada matriz (mamão, maçã e morango), totalizando 90 amostras comercializadas na cidade de São Paulo, sendo que as amostras de mamão e maçã foram adquiridas durante as quatro estações do ano, no período de 21 de dezembro de 2005 a 19 de dezembro de 2006, e as de morango no outono, inverno e primavera de 2006, distribuídas conforme ilustra a Figura 16. Procurou-se, ainda, amostrar de forma a representar todas as regiões da cidade de São Paulo (Figura 17).

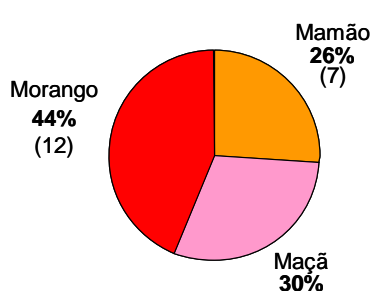

$30 \%$
$(8)$

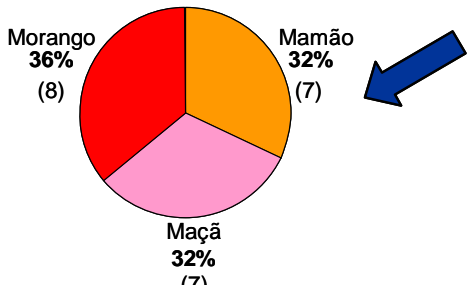

(7)

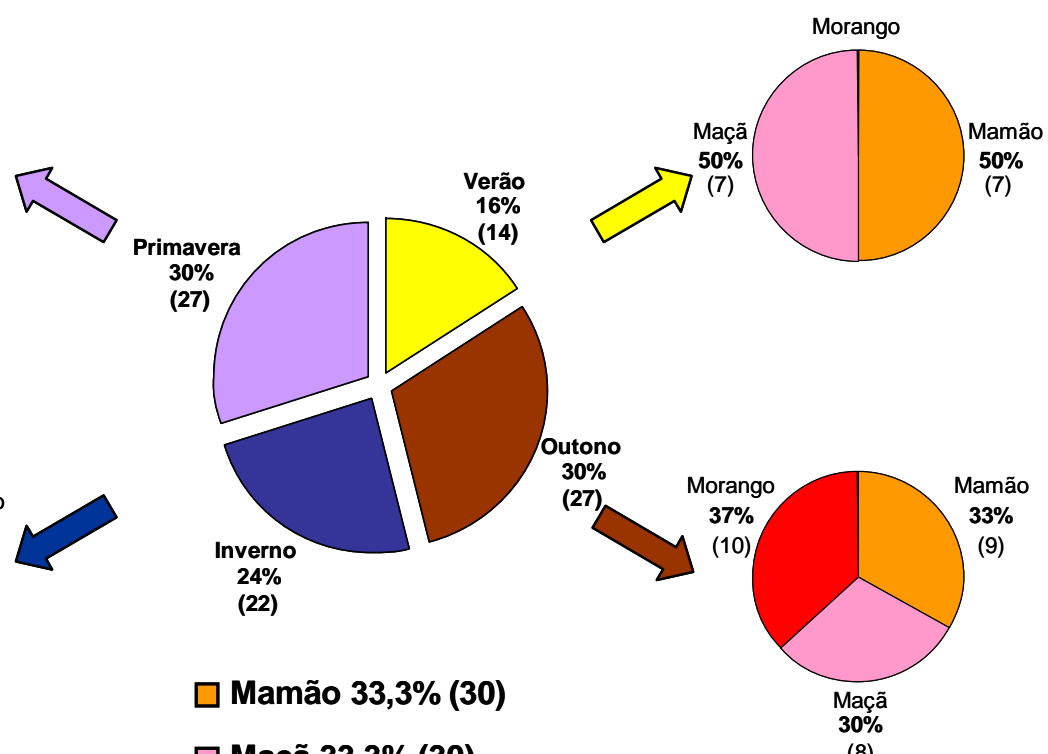

Maçã 33,3\% (30)

Morango 33,3\% (30)

Figura 16 - Número de amostras coletadas de acordo com a estação do ano, no período de 21 de dezembro de 2005 a 19 de dezembro de 2006, $(\mathrm{n}=90)$ 


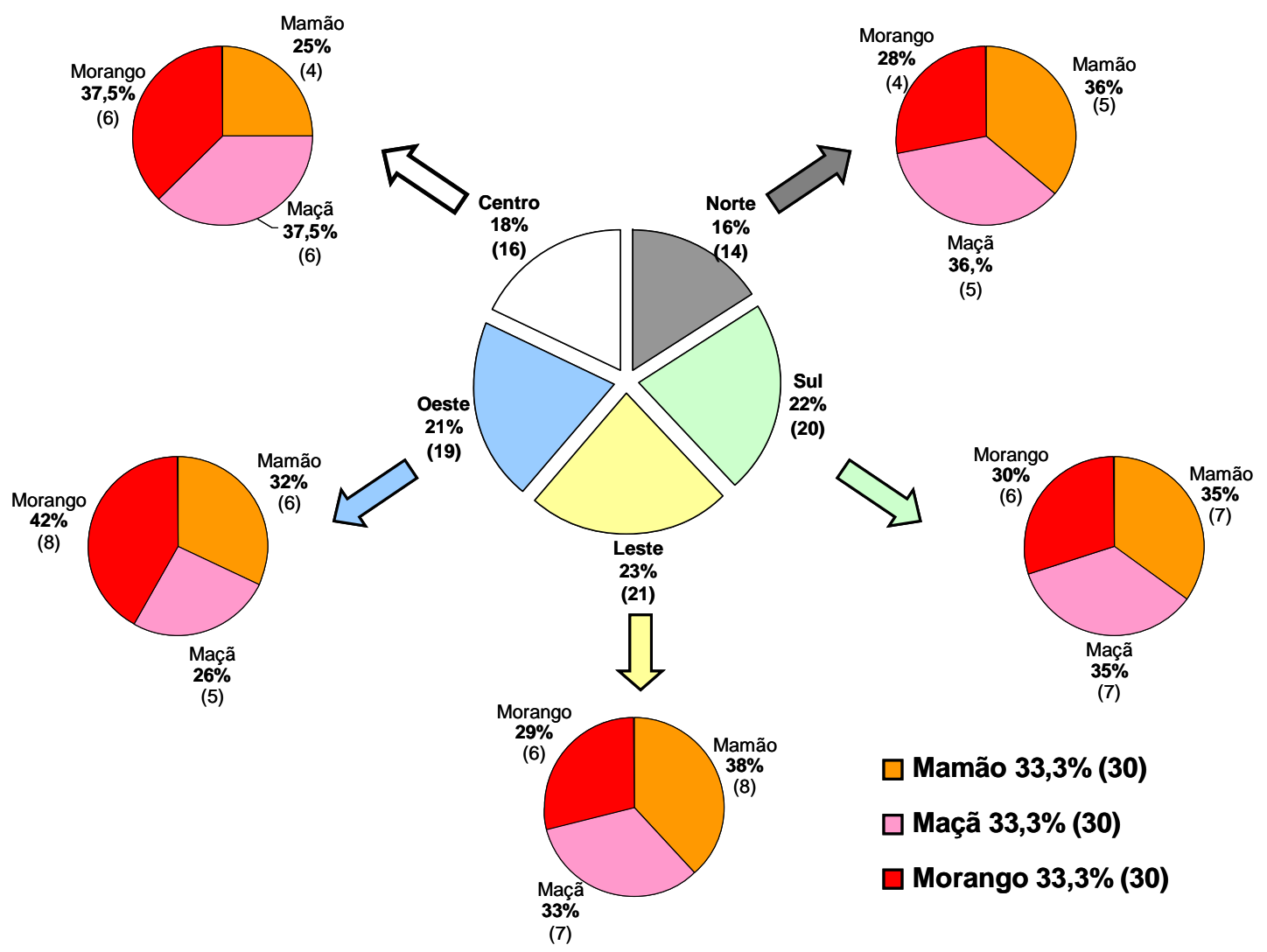

Figura 17 -Número de Amostras coletadas de acordo com a região da cidade de São Paulo-SP, no período de 21 dezembro de 2005 a 19 de dezembro de 2006, $(n=90)$

A distribuição dos locais de amostragem de acordo com a região da cidade de São Paulo encontram-se na Figura 18. 


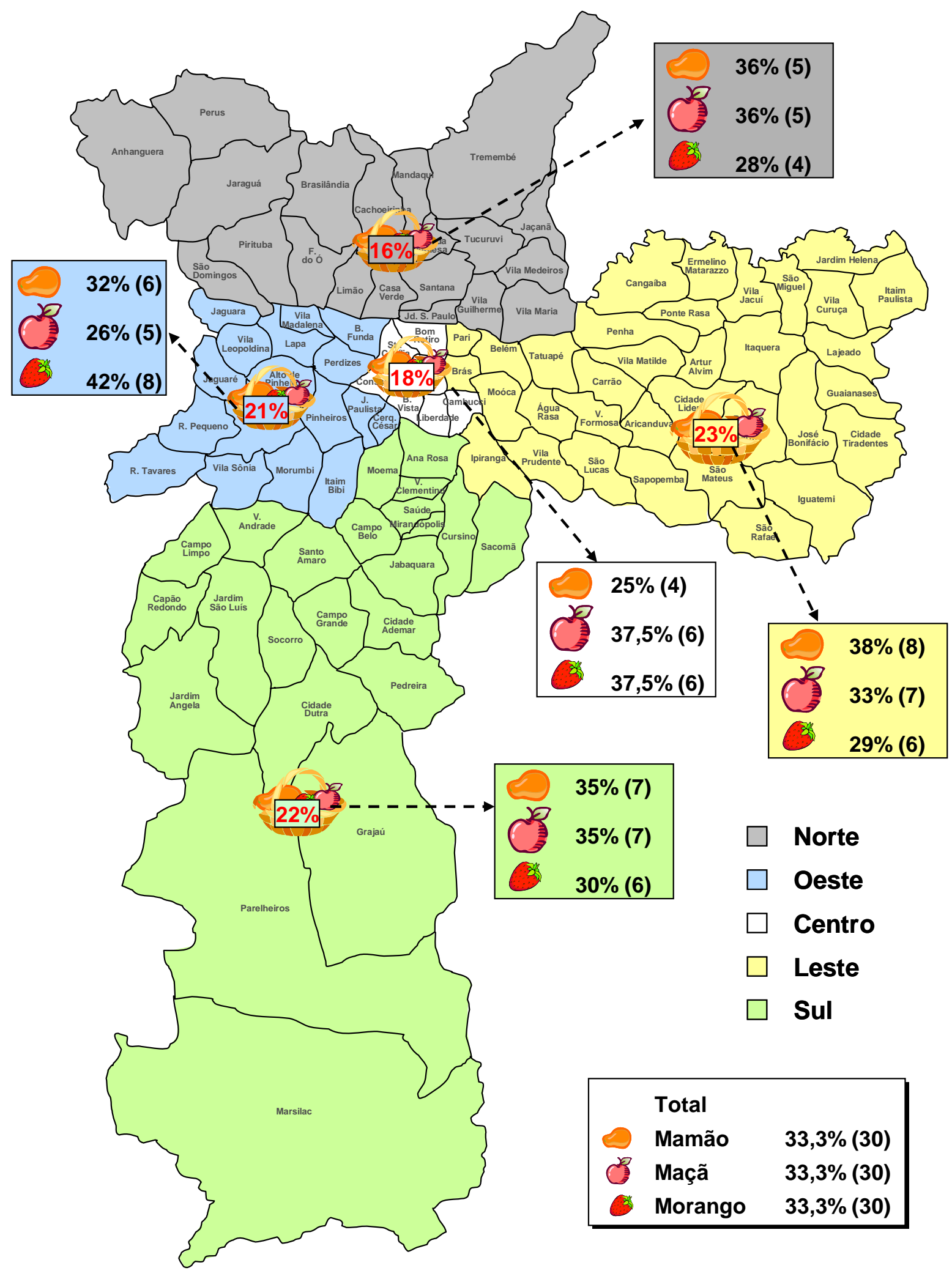


Figura 18 - Distribuição dos locais de amostragem de acordo com a região (zona) da cidade de São Paulo no período de 21/12/2005 a 19/12/2006 $(\mathbf{n}=\mathbf{9 0})$

\subsubsection{Preparação das amostras (de laboratório)}

Cada amostra coletada era muito maior do que a quantidade necessária para análise laboratorial. Os frutos de cada amostra foram quarteados, rejeitados os quartos opostos, cortados em pequenos pedaços, misturados, reduzidos para aproximadamente $200 \mathrm{~g}$, homogeinizados em liquidificador e transferidos para sacos de polietileno com zíper, de primeiro uso. As amostras foram preparadas no mesmo dia em que foram adquiridas e estocadas congeladas em freezer à temperatura de aproximadamene $-20^{\circ} \mathrm{C}$, até o início das análises no laboratório.

\subsection{Material e Métodos}

\subsubsection{Material}

\section{a) Equipamentos para detecção de ETU}

- Cromatógrafo a Líquido de Alto Desempenho (HPLC) HP1100 com detector UV, bomba quaternária, amostrador automático, microcomputador com Chemstation;

- Cromatografo a Líquido acoplado a Espectrômetro de Massas - LC/MS/MS, amostrador automático com controle de temperatura e forno de coluna termostatizado em um cromatógrafo líquido de alto desempenho Agilent 1100 Séries (Agilent Technmologies, Waldbronn, Alemanha) equipado com bomba quaternária, sistema degaseificador;

-Espectrômetro de massas triploquadrupolo API $5000^{\mathrm{TM}}$ (Applied Biosystems/MDS Sciex, Concord, Canadá), fonte de íons Turbo $\mathrm{V}^{\mathrm{TM}}$;

- Balança analítica;

- Balança semi-analítica;

- Bomba de vácuo;

- Estufa;

- Homogeinizador;

- Rotaevaporador; 
- Sistema de purificação de água para HPLC;

\section{b) Vidrarias e outros materiais:}

- Frascos de nalgene com tampa rosqueável de $300 \mathrm{~mL}$;

- Balões de $300 \mathrm{~mL}$ para rotavapor,

- Balões volumétricos de diferentes capacidades;

- Colunas de extrelut;

- Filtros de membranas de celulose regenerada de $0,45 \mu \mathrm{m}$;

- Frascos de vidro de $3 \mathrm{~mL}$, com tampa e septo de politetrafluoretileno (PTFE), para amostrador automático;

- Funis de Büchener com diâmetro de $9 \mathrm{~cm}$;

- Funil de placa porosa para filtração de solventes e água para uso no HPLC;

- kitassato de $1.000 \mathrm{~mL}$;

- Papel de filtro;

- Papel indicador de $\mathrm{pH}$ universal;

- Pipetas de nalgene e de vidro (Pasteur);

- Microsseringas de vidro de $10 \mathrm{~mL}$;

- Pipetador automático de diferentes capacidades;

- Provetas graduadas com tampa de $100 \mathrm{~mL}$;

- Provetas graduadas de $200 \mathrm{~mL}$;

- Tubos graduados com tampa de $10 \mathrm{~mL}$.

\section{c) Solventes, reagentes e outros materiais}

- Acetonitrila grau HPLC;

- Água purificada para HPLC, filtrada pelo sistema Milli Q com resistividade > $18 \Omega \mathrm{e}$, posteriormente, em sistema de filtração com placa porosa de $0,45 \mu \mathrm{m}$;

- Álcool metílico grau HPLC;

- Coluna de extração (Extrelut NT20 da Merck)

- Diclorometano grau HPLC;

- Filtro de papel qualitativo;

- Filtro de PTFE $0,45 \mu \mathrm{m}$

- Hidróxido de sódio p.a. 


\section{- Preparo dos reagentes}

- Solução de Hidróxido de Sódio 10 \%: foram pesados 10,0 g de $\mathrm{NaOH}$ em balança semi-analítica, dissolvidos e avolumados em $100 \mathrm{~mL}$ de água;

-Solução de Hidróxido de Sódio $1 \%$ : foi pesado $1,0 \mathrm{~g}$ de $\mathrm{NaOH}$ em balança semi-analítica, dissolvida e avolumada em $100 \mathrm{~mL}$ de água.

\section{d) Padrão analítico de ETU e preparo das soluções}

- Padrão de eilenotiouréia (ETU), produzido pela "Riedel-de Haën", com 99,9 \% de pureza, de acordo com certificado de análise emitido pelo laboratorio de controle de qualidade da "Sigma-Aldrich".

- Preparo da solução estoque - $1.000 \mu \mathrm{g} / \mathrm{mL}$

Foi pesado, em balança analítica, 0,100 g do padrão de ETU, em béquer de $10 \mathrm{~mL}$ e dissolvido em álcool metílico. A solução foi transferida quantitativamente para um balão volumétrico de $100 \mathrm{~mL}$, completando o volume e, posteriormente, transferida para um frasco de vidro com tampa e septo de PTFE, devidamente identificada e armazenada em freezer. A partir dessa solução foram preparadas as soluções intermediárias.

\section{- Preparo da solução intermediária - $10 \mathrm{ng} / \mu \mathrm{L}$}

A partir da solução estoque, foram transferidos, com pipetador automático, $100 \mu \mathrm{L}$ para um balão volumétrico de $10 \mathrm{~mL}$, completando o volume com a fase móvel (2\% de acetonitrila em 98\% de água purificada para HPLC). A partir desta solução foram preparadas as soluções de trabalho.

\section{- Preparo das soluções de trabalho}

A partir da solução intermediária $(10 \mathrm{ng} / \mu \mathrm{L})$, foram transferidos, com pipetador automático, diferentes volumes para os respectivos balões volumétricos de $10 \mathrm{~mL}$, completando o volume com a fase móvel. As soluções foram transferidas para os respectivos frascos de PTFE com tampa rosqueável e, posteriormente, para os frascos do injetor automático com tampa rosqueável e septo de PTFE, devidamente identificados. 
Para o preparo das curvas analíticas foram utilizadas soluções-padrão de trabalho de ETU em diferentes concentrações, dentro da faixa de linearidade do detector, avaliada no item 3.3.

\subsubsection{Método para determinação de resíduos de etilenotiouréia (ETU)}

O método utilizado para determinação de resíduos de ETU nas amostras de maçã, mamão e morango foi o descrito por Diserens (1991), com modificações (LEMES 2003).

\section{- Princípio do método}

A ETU é extraída da amostra de fruta devidamente homogeneizada com álcool metílico. O extrato orgânico é concentrado e, após ajuste do $\mathrm{pH}$, é feita uma purificação em coluna de Extrelut. O eluato é concentrado e filtrado. A determinação é feita por cromatografia a líquido de alto desempenho com detector ultravioleta (HPLC-UV) (LEMES 2003).

\section{- Extração e purificação}

Uma alíquota de 20,0 g da amostra homogeneizada foi pesada em um frasco com tampa rosqueável de nalgene. A extração foi feita com $100 \mathrm{~mL}$ de álcool metílico sob agitação (agitador automático) por 30 minutos e após, foi filtrada a vácuo. A etilenotiouréia foi reextraída com mais $50 \mathrm{~mL}$ de álcool metílico. Os filtrados foram transferidos para um balão de fundo chato e boca esmerilhada e concentrados em rotavapor, sob temperatura de $50^{\circ} \mathrm{C}$, até visualização de uma única fase. $\mathrm{O}$ extrato foi resfriado até temperatura ambiente e o $\mathrm{pH}$ ajustado a 8,5, com uma solução de hidróxido de sódio 10\%. Transferiu-se o extrato $(10 \mathrm{~mL})$ para uma coluna de Extrelut seca, com o auxílio de uma pipeta Pasteur, lavando o balão para transferência quantitativa, com água em pH 8,5. Após 20 minutos, foi eluída com $200 \mathrm{~mL}$ de diclorometano, recolhendo o eluato em balão de fundo chato contendo $5 \mathrm{~mL}$ de água purificada para HPLC. O elutato foi concentrado em rotavapor a $50^{\circ} \mathrm{C}$ até a visualização de uma única fase. Após resfriamento à temperatura ambiente, foi transferido quantitativamente para um frasco de vidro graduado com tampa de $10 \mathrm{~mL}$ e avolumado com água purificada para HPLC. Após a filtração em membrana de PTFE de 0,45 $\mu \mathrm{m}$, com o auxílio de uma seringa de vidro de $10 \mathrm{~mL}$, realizou-se a transferência do filtrado para um frasco de vidro com tampa rosqueável e batoque de 
PTFE e, posteriormente, para o frasco de vidro com tampa rosqueável e batoque de PTFE do amostrador automático e foi injetada $50 \mu \mathrm{L}$ no HPLC-UV e $20 \mu \mathrm{L}$ no LCMS/MS. A Figura 19 apresenta o fluxograma com o resumo das etapas desse procedimento.

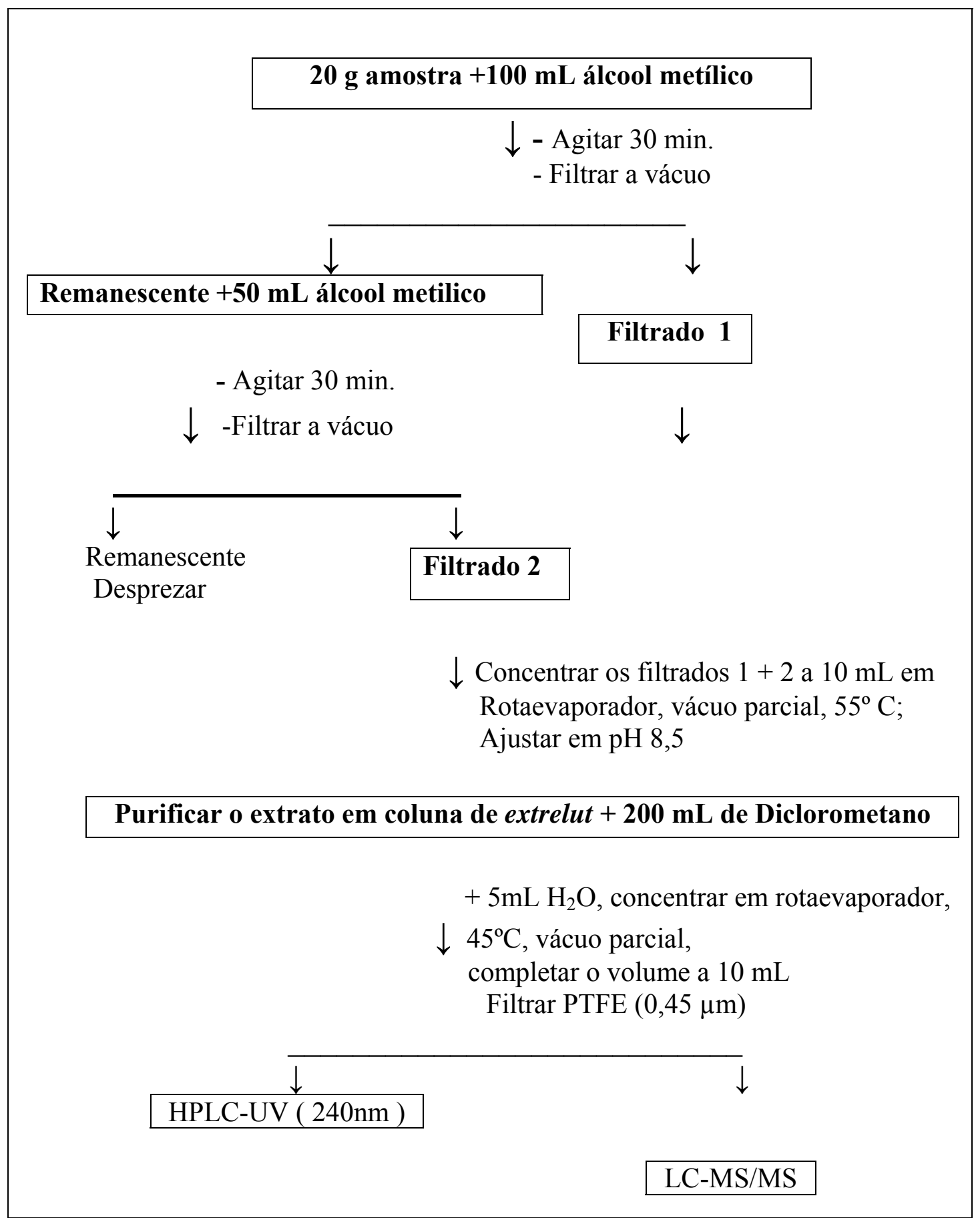

Figura 19 - Fluxograma das etapas do procedimento analítico para determinação de resíduos de ETU (LEMES 2003 com adaptações) 


\section{- Análise qualitativa e quantitativa}

A determinação foi feita por padronização externa, pela comparação dos cromatogramas das amostras com o tempo de retenção de ETU e a quantificação por comparação com a curva analítica, construída dentro da faixa de linearidade do detector, com valores de concentração x área (descrito no ítem 3.3.).

\section{- Cálculos}

A análise quantitativa foi feita por meio da curva analítica, avaliada e construída conforme descrito no item 3.3. por comparação de área. A concentração de ETU foi determinada, levando em consideração o fator de diluição e a quantidade de amostra, pela equação:

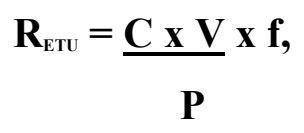

Onde:

$\mathbf{R E T U}=$ resíduo de ETU na amostra $(\mu \mathrm{g} / \mathrm{kg}) ; \mathbf{C}=$ concentração de ETU na solução final extraída da amostra $(\mathrm{g} / \mathrm{mL}) ; \mathbf{V}=$ volume da solução extraída $(\mathrm{mL})$; $\mathbf{P}=$ peso equivalente da amostra extraída $(\mathrm{g}) ; \mathbf{f}=$ fator de diluição.

O resultado foi expresso em micrograma de etilenotiouréia por quilograma da $\operatorname{amostra}(\mu \mathrm{g} / \mathrm{kg})$.

\subsection{Validação de método analítico para determinação de etilenotiouréia em frutas}

Os métodos devem conduzir a resultados confiáveis e adequados à qualidade pretendida. A validação consiste na comprovação, por intermédio do fornecimento de evidência objetiva, de que os requisitos para uma aplicação ou usos específicos pretendidos foram atendidos.

Inicialmente foi feita a otimização das condições cromatográficas. Os parâmetros de validação avaliados foram: efeito da matriz, seletividade, linearidade, intervalo de trabalho, limite de deteç̧ão, limite de quantificação do método, exatidão, precisão. A avaliação desses parâmetros foi realizada para cada matriz para 
verificar a confiabilidade e aplicabilidade do método (FAO/WHO 1993; INMETRO 2003).

\subsubsection{Número de amostras para os ensaios de validação do método}

Foram utilizadas amostras controle de maçã, mamão e morango, analisadas com 6 repetições e em três níveis de fortificação cada, totalizando 72, para realização dos ensaios de validação (Tabela 17).

Tabela 17 - Número de amostras para realização dos ensaios de validação

\begin{tabular}{|c|c|c|c|c|c|}
\hline \multirow[t]{2}{*}{ Amostra } & \multirow[b]{2}{*}{ Matriz } & \multirow[b]{2}{*}{$\begin{array}{c}\text { Nível } \\
(\mu \mathrm{g} / \mathrm{kg})\end{array}$} & \multirow[b]{2}{*}{$\begin{array}{c}\mathrm{N} \\
\text { amostra } \\
\mathrm{S} \\
\end{array}$} & \multicolumn{2}{|c|}{ Técnica } \\
\hline & & & & HPLC-UV & LC-MS/MS \\
\hline Controle & $\begin{array}{c}\text { Maçã } \\
\text { Mamão } \\
\text { Morango }\end{array}$ & $\begin{array}{c}\text { Sem } \\
\text { adição }\end{array}$ & $\begin{array}{l}6 \\
6 \\
6\end{array}$ & $\begin{array}{l}\mathrm{x} \\
\mathrm{x} \\
\mathrm{x}\end{array}$ & $\begin{array}{l}\mathrm{x} \\
\mathrm{x} \\
\mathrm{x}\end{array}$ \\
\hline $\begin{array}{l}\text { Fortificada } \\
\text { Nível } 1\end{array}$ & $\begin{array}{c}\text { Maçã } \\
\text { Mamão } \\
\text { Morango }\end{array}$ & 1 & $\begin{array}{l}6 \\
6 \\
6\end{array}$ & & $\begin{array}{l}\mathrm{x} \\
\mathrm{x} \\
\mathrm{x}\end{array}$ \\
\hline $\begin{array}{l}\text { Fortificada } \\
\quad \text { Nível } 2\end{array}$ & $\begin{array}{c}\text { Maçã } \\
\text { Mamão } \\
\text { Morango }\end{array}$ & 2 & $\begin{array}{l}6 \\
6 \\
6\end{array}$ & & $\begin{array}{l}\mathrm{x} \\
\mathrm{x} \\
\mathrm{x}\end{array}$ \\
\hline $\begin{array}{c}\text { Fortificada } \\
\text { Nível } 3\end{array}$ & $\begin{array}{c}\text { Maçã } \\
\text { Mamão } \\
\text { Morango }\end{array}$ & 10 & $\begin{array}{l}6 \\
6 \\
6\end{array}$ & $\begin{array}{l}\mathrm{x} \\
\mathrm{x} \\
\mathrm{x}\end{array}$ & $\begin{array}{l}\mathrm{x} \\
\mathrm{x} \\
\mathrm{x}\end{array}$ \\
\hline $\begin{array}{l}\text { Total de cada } \\
\text { matriz de } \\
\text { estudo }\end{array}$ & $\begin{array}{c}\text { Maçã } \\
\text { Mamão } \\
\text { Morango }\end{array}$ & & $\begin{array}{l}24 \\
24 \\
24\end{array}$ & $\begin{array}{l}12 \\
12 \\
12\end{array}$ & $\begin{array}{l}24 \\
24 \\
24\end{array}$ \\
\hline Total & & & 72 & 36 & 72 \\
\hline
\end{tabular}

$\mathrm{N}=$ número de replicatas

\section{a) Amostra controle}

A amostra controle, utilizada para realizar a validação do método analítico, corresponde à matriz da mesma espécie, previamente analisada, e que não apresentou 
o analito de interesse.

Para realização dos estudos de validação do método foram adquiridas, em supermercados da cidade de São Paulo (Anexo 2), amostras de maçã e morango de produção orgânica, sem uso de agrotóxicos, para representarem as amostras controle. No caso do mamão, foi utilizada uma amostra na qual não foi detectado resíduo de ETU.

b) Amostra fortificada

A amostra fortificada, utilizada para avaliar o método corresponde a uma amostra controle, na qual foi adicionada determinada concentração do analito a ser determinado.

\subsubsection{Seletividade}

Os métodos devem ser capazes de determinar os analitos na presença da matriz a ser analisada (INMETRO 2003).

\section{- Análise em branco do método}

Foi realizada a análise em branco do método, em triplicata, conforme procedimento analítico, descrito no item 3.2, sem a presença da amostra e de ETU para verificar a ausência de interferentes na região de estudo, provenientes de solventes, vidraria, reagentes e outros.

\section{- Análise da amostra controle}

Amostras-controle das matrizes de estudo foram analisadas, com seis repetições, de acordo com o procedimento descrito no item 3.2, para verificar a existência ou não de interferentes na análise.

\subsubsection{Estudo da faixa de linearidade de resposta do detector}

Linearidade - é a habilidade de um método analítico em produzir resultados que sejam diretamente proporcionais às concentrações do analito em amostras (INMETRO 2003). Deve ser checada pela construção de uma curva analítica com pontos cobrindo a faixa de concentração esperada e os resultados devem ser avaliados por métodos estatísticos apropriados; por exemplo, por cálculo da regressão linear utilizando o método dos mínimos quadrados (ICH - International 
Conference on Harmonization of Technical Requirements for Registration of Pharmaceuticals for Human Use, 1997).

Avaliação da linearidade foi conduzida conforme procedimentos propostos por Souza e Junqueira (2005) e Souza (2007). O protocolo detalhado para avaliação da linearidade por regressão simples incluí etapas de tratamento de outliers, checagem de premissas dos erros da regressão (normalidade, homoscedasticidade e independência) e avaliação do ajuste ao modelo.

- Outliers - observações divergentes.

- Normalidade - a distribuição normal é uma distribuição de variável aleatória comum, que surge em muitas situações onde valores extremos são menos prováveis do que valores moderados.

- Homoscedasticidade ou homogeneidade de variâncias - quando as dispersões respectivas são equivalentes, ou seja, quando as diferenças observadas entre suas variâncias não são estatisticamente significativas.

- Independência - no modelo da regressão assume-se que todos os erros são independentes. Porém, quando um valor positivo do erro de um período tem maior chance de ser seguido por outro valor positivo no período seguinte, os erros não são independentes.

A adequação para uso do método foi determinada com base nos resultados dos parâmetros estabelecidos (linearidade, efeitos de matriz, seletividade, exatidão, precisão, limites de detecção e de quantificação), considerando os critérios de aceitabilidade determinados. O nível de significância adotado nos testes de hipóteses foi $\alpha=0,05$.

Uma curva analítica foi preparada, com 7 níveis de concentração 1,0, 2,0, 5,0, $10,0,15,0,20,0$ e $25,0 \mathrm{ng} / \mathrm{mL}$, sendo três replicatas independentes de cada nível. As soluções foram analisadas em ordem aleatória. Brancos foram preparados, também em triplicata, para avaliação do ruído, mas não foram incluídos nos cálculos.

O método dos mínimos quadrados ordinários (MMQO) foi aplicado aos dados da curva para estimativa dos parâmetros da regressão. Outliers foram investigados pelo teste de resíduos padronizados Jacknife, o qual foi aplicado sucessivamente até que novos outliers não fossem detectados ou até uma exclusão máxima de $22,2 \%$ no 
número original de resultados. Violações das premissas relacionadas ao MMQO foram avaliadas: normalidade (teste de Ryan-Joiner), homoscedasticidade (teste de Brown-Forsythe) e independência dos resíduos da regressão (teste de DurbinWatson). Testes de $\mathrm{F}$ foram conduzidos para verificar o ajuste ao modelo linear por meio da avaliação das significâncias da regressão e do desvio da linearidade.

\section{- Faixa Linear de Trabalho ou intervalo de trabalho}

A faixa linear de trabalho de um método de ensaio é o intervalo entre os níveis inferior e superior de concentração do analito no qual foi demonstrado ser possível a determinação com exatidão, precisão e linearidade exigidas, sob as condições experimentais utilizadas. A faixa de trabalho deve cobrir a faixa de aplicação para a qual o ensaio vai ser usado. Os valores medidos obtidos têm que estar linearmente correlacionados às concentrações. Isso requer que os valores medidos próximos ao limite inferior da faixa de trabalho possam ser distinguidos dos brancos dos métodos. Em geral, serão necessários vários pontos de calibração, de preferência mais que seis, para determinar a faixa de trabalho (INMETRO 2003).

Foi realizada a análise em branco do método e das amostras controle de maçã, mamão e morango.

O intervalo da faixa de linearidade do detector deve ser obtido pela determinação da resposta do detector com soluções-padrão de ETU em diferentes concentrações.

Foi verificada a existência de pontos dispersos, sendo excluídos os valores dispersos e aplicados os procedimentos descritos por Souza e Junqueira (2005) e Souza (2007), conforme já citado, para confirmar a linearidade.

\subsubsection{Construção da curva analítica}

Resíduos de ETU foram determinados por padronização externa pela comparação de área com curvas analíticas construídas em sete níveis de concentração.

Neste estudo foram utilizadas soluções-padrão de ETU em 7 diferentes concentrações: 1/2LQ， 1,0LQ，2,5LQ， 5,0LQ， 7,5LQ， 10,0LQ e 12,5LQ, correspondentes a 10,0, 20,0 (LQ), 50,0, 100,0, 150,0, 200,0 e 250ng/mL, para 
construção da curva analítica para determinação no HPLC/UV, e de 1,0, 2,0 (LQ), 5,0, 10,0, 15,0, 20,0, 25,0 ng/mL para quantificação no LC/MS/MS.

\subsubsection{Limite de Quantificação (LQ)}

O limite de quantificação do método é definido como a menor concentração do analito em uma amostra que se pode determinar com precisão aceitável (EUROPEAN COMISSION 2000a). O intervalo de aceitabilidade para os valores individuais de recuperação para cada nível de fortificação é de 70 a $110 \%$ e o coeficiente de variação porcentual $(\mathrm{CV} \%)$ em relação à média para cada nível estudado deve ser igual ou menor que 15\% (EUROPEAN COMMISSION 2000b; FAO/WHO 1993). A EPA (1996) considera valores de recuperações entre 70 e 120\% para aceitabilidade de métodos.

O limite de quantificação, após ser determinado pela curva e análise da matriz, foi testado com adição de ETU às amostras de frutas controle na concentração do LQ. As análises foram realizadas com seis repetições, segundo o procedimento descrito. Foram calculadas as recuperações em porcentagem, médias, desvios padrão e coeficientes de variação para verificação da aceitabilidade dos resultados.

\subsubsection{Limite de Detecção (LD)}

Limite de detecção é definido como a menor quantidade do analito presente em uma amostra que pode ser detectado, porém não necesariamente quantificado, sob as condições experimentais estabelecidas. Estabelecido por meio de análises de concentrações conhecidas e decrescentes do analito até o menor nível detectável. Pode ser feita utilizando a relação 3 vezes o ruído da linha de base (ANVISA 2006).

Segundo ICH (1997), o cálculo do limite de detecção pode ainda ser calculado em 3,3 vezes o slope da curva de calibração.

Neste estudo, o limite de detecção foi calculado pelas duas maneiras: 3 vezes o ruído da linha de base e 3,3 vezes o slope da curva de calibração, sendo considerado o maior valor deles. Além disso foi feita avaliação visual dos cromatogramas da amostra do branco, com três repetições e das matrizes de maçã, mamão e morango 
(amostras controle), realizadas com seis repetições cada, considerando o maior sinal ruído observado.

\subsubsection{Exatidão}

Exatidão do método é definida como sendo a concordância entre o resultado de um ensaio e o valor de referência aceito como convencionalmente verdadeiro. Quando aplicada a uma série de resultados de ensaio, implica numa combinação de componentes de erros aleatórios e sistemáticos (tendência) (INMETRO 2003).

Os procedimentos normalmente utilizados para avaliar a exatidão de um método são: uso de materiais de referência, participação em ensaios interlaboratoriais e realização de ensaios de recuperação, em três níveis com 7 repetições cada (INMETRO 2003). A ANVISA, em 2006, estabeleceu um mínimo de 2 níveis com 5 repetições nos estudos de recuperação e validação de métodos de resíduos de agrotóxicos em alimentos.

Neste estudo, a tendência foi determinada com base nos resultados de recuperação analítica (\%) (valor observado/valor esperado), realizada em três níveis de concentrações, com seis repetições cada.

O intervalo de aceitabilidade para os valores individuais de recuperação é de 70 a 110\% (FAO/WHO 1993; EUROPEAN COMISSION 2000b). A EPA (1996) e RDC 216 (ANVISA2006) consideram valores de variabilidade para determinação da aceitabilidade de métodos recuperações entre 70 e $120 \%$.

Recuperações não demonstram, por si, exatidão ou tendências de resultados, o analista deve participar de programas de controle de qualidade interlaboratorial, quando disponíveis e acessíveis. O laboratório de Resíduos de Pesticidas do Instituto Adolfo Lutz participa em testes interlaboratoriais de proficiência de ditiocarbamatos, pois os de ETU não estão disponíveis e acessíveis no momento.

\section{- Estudos de recuperação}

Para os estudos de recuperação de ETU, foram preparadas, com seis repetições, amostras controle de cada fruta, pela adição de $1 \mathrm{~mL}$ de cada soluçãopadrão na concentração de $0,2 \mathrm{ng} / \mathrm{mL}$ a 20,0 g de amostra controle, para obter 
concentração de 10,0 $\mu \mathrm{g} / \mathrm{kg}$ e, em seguida, analisadas em HPLC/UV, segundo o procedimento descrito. Foi ainda adicionado $1 \mathrm{~mL}$ de cada solução-padrão nas concentrações de $0,02 \mathrm{ng} / \mathrm{mL}$ e de $0,04 \mathrm{ng} / \mathrm{mL}$, respectivamente, a 20,0 g de amostra controle, com seis repetições, para obter concentrações de $1,0 \mu \mathrm{g} / \mathrm{kg}$ e $2,0 \mu \mathrm{g} / \mathrm{kg}$.

A relação entre a concentração encontrada e adicionada para cada amostra fortificada, foi calculada em porcentagem, isto é, as recuperações, a média, o desviopadrão e o coeficiente de variação para cada nível estudado.

\subsubsection{Precisão}

Precisão é um termo geral para avaliar a dispersão de resultado entre ensaios independentes, repetidos de uma mesma amostra, em condições experimentais definidas. É normalmente determinada para circunstâncias específicas de medição e as duas formas mais comuns de expressá-la são por meio da repetitividade e da reprodutibilidade, sendo usualmente expressa como desvio padrão ou desvio padrão relativo (INMETRO 2003). Em análise de resíduos, a precisão é determinada por desvios padrão relativos ou coeficientes de variação porcentual em relação à média, obtidos nos experimentos de recuperação em cada nível estudado.

$\mathrm{O}$ coeficiente de variação porcentual $(\mathrm{CV} \%)$ em relação à média deve ser $15 \%$, de acordo com EUROPEAN COMMISSION (2000b), e de 20\% conforme estabelecido pela ANVISA (2006).

\section{- Repetitividade}

Repetitividade é o grau de concordância entre os resultados de medições sucessivas de um mesmo analito, efetuadas sob as mesmas condições, chamadas de condições de repetitividade, ou seja, é a dispersão dos resultados de recuperação, usando o mesmo método, a mesma matriz, em um único laboratório, dentro de um curto período, no qual não ocorram diferenças em materiais e equipamentos usados e/ou analistas envolvidos (INMETRO 2003).

O coeficiente de variação porcentual $(\mathrm{CV} \%)$ em relação à média para cada nível de fortificação deve ser 15\% (EUROPEAN COMMISSION 2000b).

\section{- Reprodutibilidade interna}


Foi avaliada ainda a reprodutibilidade interna com dados obtidos no laboratório, pelo mesmo analista, por HPLC-UV, com algumas alterações, como mudança de coluna (fase estacionária) e fluxo da fase móvel comparados com os resultados de um estudo anterior realizado pela autora (LEMES 2003).

\section{- Robustez}

Em relação à robustez, estudos de recuperações foram realizados em diferentes matrizes de frutas (mamão e morango), no presente estudo, com algumas modificações, como mudança da coluna e equipamento para quantificação. Deve-se destacar que quanto maior for a robustez de um método, maior será a confiança desse relacionado à sua precisão (INMETRO 2003).

\subsection{Avaliação de risco de exposição à ETU pela ingestão de frutas}

\subsubsection{Estimativa de risco pela ingestão de maçã, mamão e morango}

Com os valores de resíduos de ETU, encontrados nas amostras de frutas (maçã, mamão e morango), considerando os maiores valores, foi verificada a contribuição do risco, pelo consumo das mesmas. Foi calculada multiplicando-se a média de consumo alimentar per capita para a cidade de São Paulo (IBGE 2005) pelos maiores valores encontrados nas amostras de maçã, mamão e morango neste estudo, supondo que todas as frutas consumidas continham esses níveis. Após foi comparada com IDA para ETU, estabelecida pelo Codex Alimentarius (FAO/WHO 1994), para população em geral e com a dose oral crônica de efeito não carcinogênico (Drf), incluindo subgrupos sensíveis da população (como crianças, gestantes), estabelecida pelo EPA (2007a) e foi expressa em porcentagem relativa.

\subsubsection{Estimativa do risco de exposição a EBDC pelos resultados obtidos nos alimentos analisados pelo PARA (2001-2004)}

Foram utilizados dados obtidos em estudo de monitoramento realizado no Brasil no período de 2001 a 2004 (ANVISA 2005). A estimativa do risco de exposição à EBDC foi calculada pela média de consumo alimentar per capita para a cidade de São Paulo (IBGE 2005), supondo que todas as frutas consumidas 
apresentassem os maiores níveis de ditiocarbamatos encontrados no PARA de 0,03 $\mathrm{mg} / \mathrm{kg} /$ dia de $\mathrm{CS}_{2}$ para população em geral. Após, foi comparada com IDA para EBDC (mancozebe, manebe, metiram), estabelecida para cada princípio ou em qualquer combinação de acordo o estabelecido na legislação (MINISTÉRIO DA SAÚDE 2003), e foi expressa em porcentagem relativa.

\subsubsection{Estimativa do risco de exposição a ETU (calculada) pelos resultados obtidos nos alimentos analisados pelo PARA (2001-2004)}

A estimativa do risco de exposição à ETU foi calculada pela média de consumo alimentar per capita para a cidade de São Paulo (IBGE 2005), supondo que todas as frutas consumidas apresentassem os maiores níveis de ditiocarbamatos encontrados no PARA e, como não existem dados de resíduos de ETU para a maioria dos alimentos, foi estimado o risco de exposição à ETU, baseado em estudos de conversão de EBDC à ETU (ref) e considerando que os dititocarbamatos em $\mathrm{CS}_{2}$, encontrados no PARA (2001-2004) eram provenientes do uso de EBDC. Após foi comparada com IDA para ETU, estabelecida pelo Codex Alimentarius (FAO/WHO 1994), para população em geral e com a dose oral crônica de efeito não carcinogênico (Drf), incluindo subgrupos sensíveis da população (como crianças, gestantes), estabelecida pelo EPA (2007a) e foi expressa em porcentagem relativa. 


\section{RESULTADOS E DISCUSSÃO}

A determinação de resíduos de ETU pode ser feita pela análise direta por cromatografia a líquido de alto desempenho com detector UV ou após derivatização para formação de outros compostos mais estáveis para determinação pela cromatografia a gás com vários sistemas de detecção, tais como Detector de Captura de Elétrons (ECD), de Nitrogênio e Fósforo (NPD), ou Cromatografia a gás / Espectrometria de Massas (CG/MS). Em estudo realizado anteriormente pela autora, foi feita uma revisão e avaliação de métodos descritos na literatura para análise de ETU (LEMES 2003). Atualmente, também, a ETU tem sido determinada por Cromatografia a Líquido acoplada à Espectrometria de Massas em tandem (LC/MS/MS).

A análise de ETU por cromatografia a gás por derivatização, devido ao fato dos produtos formados serem muito voláteis, exige muito cuidado durante $\mathrm{o}$ procedimento analítico, principalmente na etapa de concentração do extrato, requerendo maior tempo de análise e uso de reagentes muito tóxicos.

Em altas temperaturas, resíduos de ETU podem ser degradados, e este é o principal motivo pela escolha de se trabalhar com Cromatografia a Líquido de Alto Desempenho (HPLC), ao invés de CG, pois permite trabalhar em temperatura baixa $\left(30^{\circ} \mathrm{C}\right)$ e determinar ETU diretamente, sem necessidade de derivatização, requerendo ainda menor tempo de análise e utilizando menos reagentes. A escolha e uso da fase estacionária, $5 \mu$ de Metalasil AQ C18 120 A, neste estudo foi devido ao fato de ser possível trabalhar com alto teor de água na fase móvel, o que, no caso da análise de ETU, é muito interessente, pois, além da ETU ser altamente solúvel em água, permite a diminuição do uso de solventes tóxicos.

A espectrometria de massas em tandem - MS/MS analisa os íons produtos formados por ativação (usualmente por uma ou mais colisões) de um íon precursor, previamente selecionado. A dessolvatação dos íons na técnica de ionização por electrospray ocorre a baixas temperaturas e de forma gradual, com pequena ou nenhuma fragmentação dos íons presentes na solução. Este tipo de mecanismo permite que a estrutura dos íons observados na fase gasosa tenha a mesma estrutura 
dos íons presentes na fase líquida, podendo ser aplicado para análise de espécies não voláteis e termolábeis (MARTINS 2005). Como ETU degrada em altas temperaturas, esta foi a técnica escolhida para avaliar este analito em frutas nesta pesquisa.

A técnica utilizando pressão atmosférica ionizante na espectrometria de massa proporciona grande sensibilidade e seletividade. Técnicas com equipamentos em seqüência, como espectrometria de massa acoplada à ionização com eletrospray, têm demonstrado serem úteis na determinação de diferentes agrotóxicos (SANNINO e col. 2004).

Cromatografia líquida acoplada à espectrometria de massas em tandem com ionização por electrospray foi empregada na etapa experimental desta pesquisa devido à alta sensibilidade da técnica (dez vezes maior do que no HPLC-UV), e por dar resposta inequívoca da identidade de ETU.4.1. Otimização das condições analíticas ialmente foi feita a otimização das condições cromatográficas.

Foram injetadas soluções padrão de ETU no HPLC-UV e LC-MS/MS.

\section{- HPLC-UV}

Após as condições cromatográficas serem otimizadas de modo a se obter um cromatograma com boa resolução para o pico de interesse (ETU), as amostras foram injetadas no HPLC-UV. Essas condições, descritas por Diserens (1991), foram estudadas em amostra de mamão e obtidas em estudo anterior realizado pela autora (LEMES 2003). No presente estudo, foram feitas algumas modificações: troca da fase estacionária por $5 \mu \mathrm{m}$ de Metalasil AQ C18 $120^{\mathrm{a}}$ e o fluxo da fase móvel utilizado foi de $1 \mathrm{~mL} / \mathrm{min}$.

O equipamento utilizado foi um Cromatógrafo a Líquido de Alto Desempenho (HP 1100), com detector de UV, bomba quaternária, sistema degaseificador, amostrador automático, com controle de temperatura e forno de coluna termostatizado, microcomputador com Workstation; detector UV (comprimento de onda $=240 \mathrm{~nm})$; coluna com pré-coluna de aço inox, $(250 \mathrm{~mm} \times 4,6 \mathrm{~mm})$, fase estacionária: $5 \mu$ de Metalasil AQ C18 120A; fase móvel: 2\% de acetonitrila em 98\% de água purificada para HPLC; fluxo da fase móvel: $1 \mathrm{~mL} / \mathrm{min}$.; temperatura do forno: $30^{\circ} \mathrm{C}$; volume injetado: $50 \mu \mathrm{L}$.

Obteve-se boa resolução para o pico de ETU, conforme pode ser observado no cromatograma (a) da figura 20. 


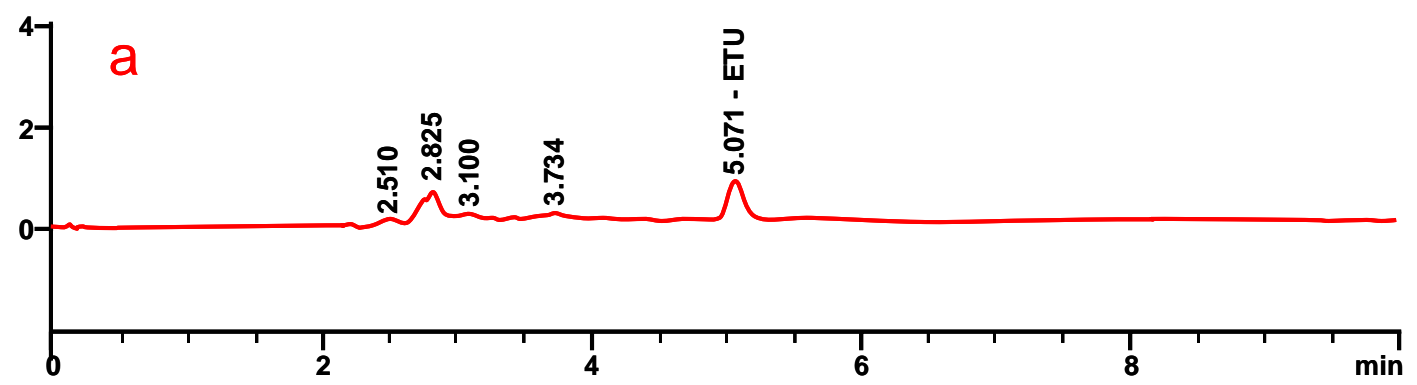

Figura 20 - Cromatograma referente ao padrão de ETU na concentração de 20,0ng/mL por HPLC-UV

- Cromatografia a Líquido acoplada à Espectrometria de Massas LC/MS/MS

Foi utilizado um HPLC Agilent 1100 Séries (Agilent Technmologies, Waldbronn, Alemanha) equipado com bomba quaternária, sistema degaseificador, amostrador automático com controle de temperatura $\mathrm{e}$ forno de coluna termostatizado, coluna (100 mm x 2,1 mm), fase estacionária: 3,5 $\mu \mathrm{m}$ de Symetry $\mathrm{C} 18$; temperatura do forno: $25^{\circ} \mathrm{C}$; volume injetado: $20 \mu \mathrm{L}$. A fase móvel consistiu de solução aquosa de acetato de amônio na concentração de 5,0 mmol/L (Fase A) e uma solução contendo metanol/água (95/5, v/v) (Fase B). As amostras foram injetadas em sistema isocrático de eluição contendo $30 \%$ da fase A e $70 \%$ da fase B.

\section{- Cromatografia a líquido acoplada à espectrometria de massas}

As determinações foram feitas em um espectrômetro de massas triploquadrupolo API $5000^{\mathrm{TM}}$ (Applied Biosystems/MDS Sciex). A técnica de electrospray no modo de íons positivos foi utilizada para a ionização da ETU. O capilar do electrospray foi mantido em $5.500 \mathrm{~V}$. Nitrogênio foi utilizado como cortina de gás de dessolvatação à pressão de 10 psi na fonte de íons, e como gás de colisão na célula (Q2), à pressão de 6 u.a. (unidades arbitrárias). Ar sintético ultrapuro foi utilizado como gás nebulizante e como gás secante na fonte de ionização, ambos à pressão de 50 psi.

Todas as análises foram realizadas em modo de Monitoramento de Reações Múltiplas (MRM), selecionando 3 transições de massa/carga $(\mathrm{m} / \mathrm{z})$ para o analito. Um dwell time de $300 \mathrm{~ms}$ foi empregado para monitoramento das transições do analito 
com tempo de pausa entre transições de $5 \mathrm{~ms}$. O primeiro (Q1) e o terceiro (Q3) dos quadrupolos (Q0, Q1, Q2 e Q3) foram operados em resolução unitária $(0,7+/-0,1$ u.m.a.) e o potencial de entrada do Q0 foi de $10 \mathrm{~V}$ durante toda a otimização e análises. As aquisições e o tratamento dos dados foram realizados utilizando o software Analyst versão 1.4.1.

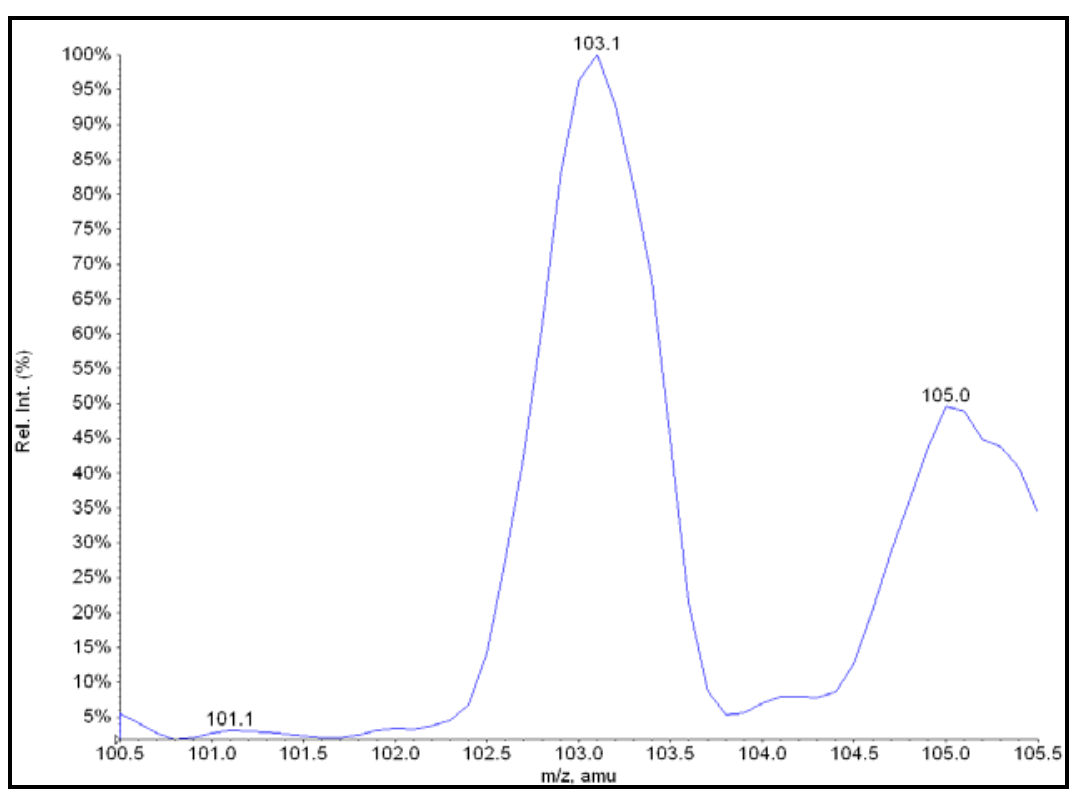

Figura 21 - Espectro de massas MS da molécula protonada $[\mathrm{M}+\mathrm{H}]^{+}$da ETU obtido em ionização por electrospray no modo de íons positivos

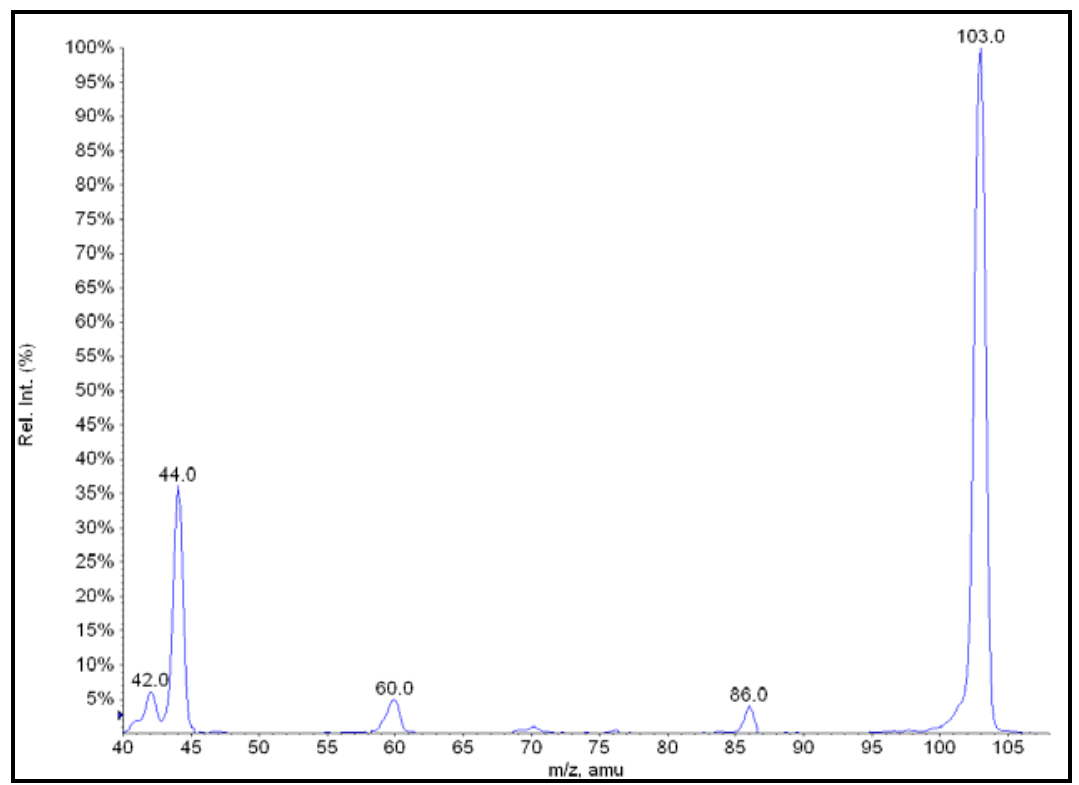


Figura 22 - Espectro de massas MS/MS da ETU obtido com o rampeamento da energia de colisão de 5 a $130 \mathrm{eV}$

A Tabela 18 apresenta os parâmetros otimizados para cada transição de $\mathrm{m} / \mathrm{z}$ do analito. Estes parâmetros são: o potencial do orifício (DP), a energia de colisão (CE) e o potencial de saída da cela de colisão (CXP).

Tabela 18 - Parâmetros otimizados para a ETU no modo MRM

\begin{tabular}{ccccc}
\hline \multirow{2}{*}{ Analyte } & $\begin{array}{c}\text { Transition } \\
(\boldsymbol{m} / \mathbf{z})\end{array}$ & $\begin{array}{c}\text { DP } \\
(\mathbf{V})\end{array}$ & $\begin{array}{c}\mathbf{C E} \\
(\mathbf{e V})\end{array}$ & $\begin{array}{c}\mathbf{C X P} \\
(\mathbf{V})\end{array}$ \\
\hline \multirow{3}{*}{ ETU } & $103.1>44.0$ & 41 & 33 & 18 \\
& $103.1>86.0$ & 41 & 29 & 32 \\
& $103.1>60.0$ & 41 & 45 & 22 \\
\hline
\end{tabular}

Foram monitoradas três transições de $\mathrm{m} / \mathrm{z}$ para determinação de ETU no LC/MS/MS. A Figura 23 apresenta um cromatograma obtido para o composto nas três transições de $m / z$ monitoradas. A cor azul corresponde à transição de $m / z$ 103.1>44.0, a cor vermelha à transição de $m / z$ 103.1>86.0 e a cor verde à transição de $m / z 103.1>60.0$.

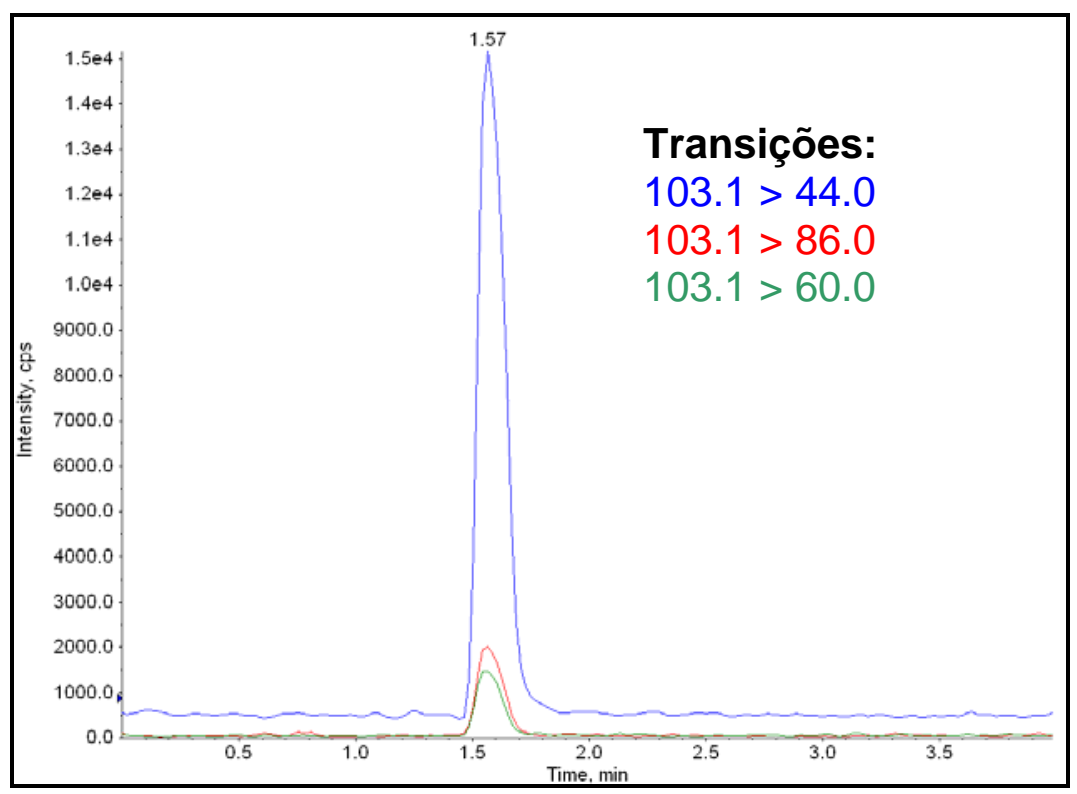


Figura 23 - Espectros de massas do padrão de ETU à concentração de 25,0 ng/mL obtidos em modo MRM

\subsection{Parâmetros avaliados para validação do método analítico:} seletividade, linearidade, intervalo de trabalho, exatidão, precisão, limite de detecção e de quantificação

\section{- Seletividade}

O branco de solventes e reagentes, realizado sem a presença de matriz, não apresentou interferentes no tempo de retenção da ETU por HPLC-UV, conforme pode ser observado no cromatograma (b) da Figura 24.

Não foram encontrados resíduos de ETU nas amostras controle de maçã, mamão e morango no HPLC-UV, no limite de quantificação do método de $10,0 \mu \mathrm{g} / \mathrm{kg}$. O limite de detecção foi de $5,0 \mu \mathrm{g} / \mathrm{kg}$.

A análise do branco do procedimento completo por LC/MS/MS não revelou a presença de ETU no limite de detecção do método de $0,5 \mu \mathrm{g} / \mathrm{kg}$. Os cromatogramas da análise e do padrão de ETU no nível correspondente LD do método estão ilustrados abaixo para comparação dos mesmos (Figuras 25 e 26).

Não foram encontrados resíduos de ETU nas amostras controle de maçã, mamão e morango (Figuras 27, 28 e 29). 

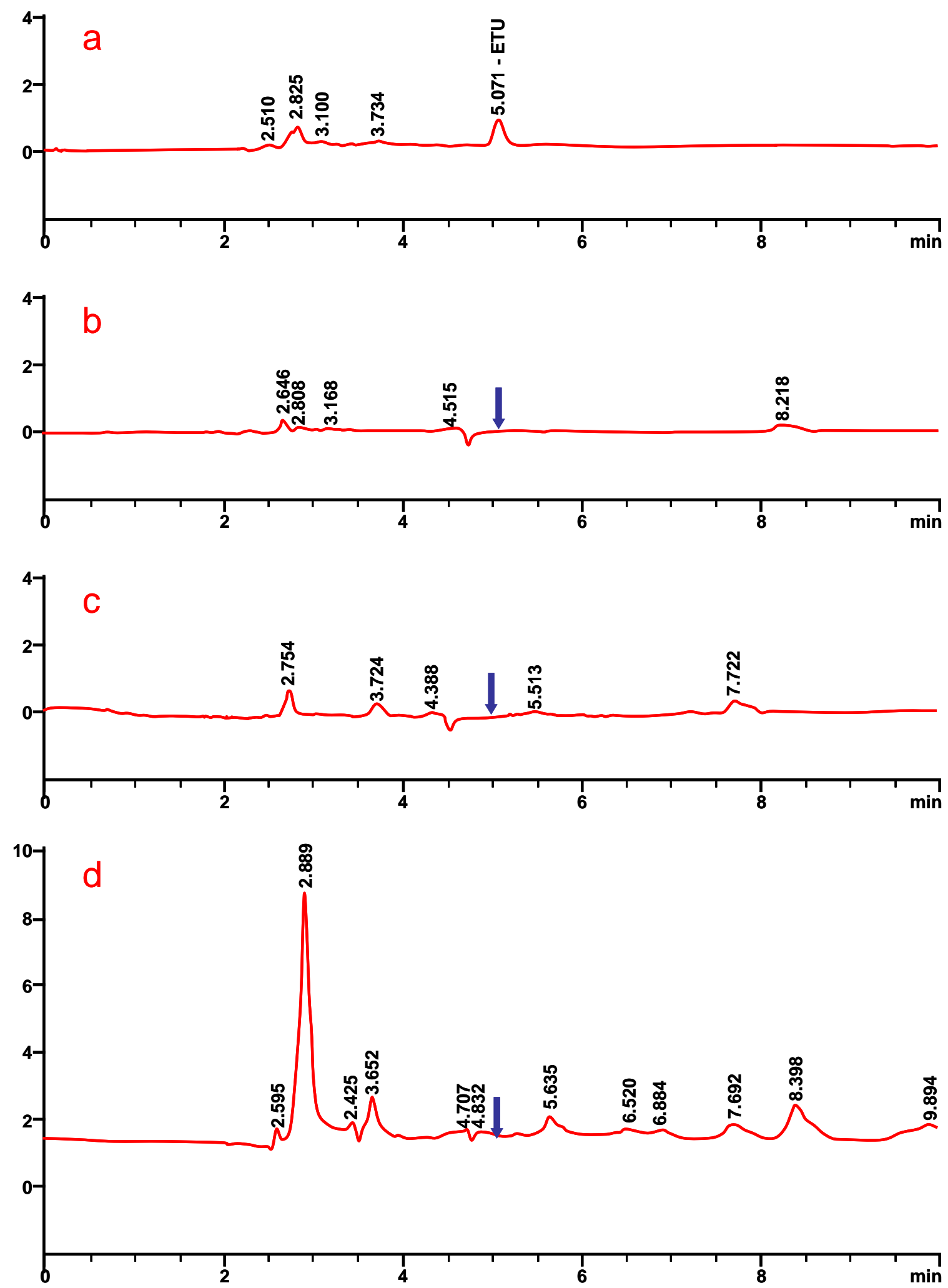

(a) padrão de ETU (20ng/mL; (b) branco do método; (c) amostra de maçã (controle);

(d) amostra de morango (controle)

Figura 24 - Cromatogramas do padrão de ETU e das amostras controle por HPLC-UV nas condições cromatográficas descritas no item 4.1. 


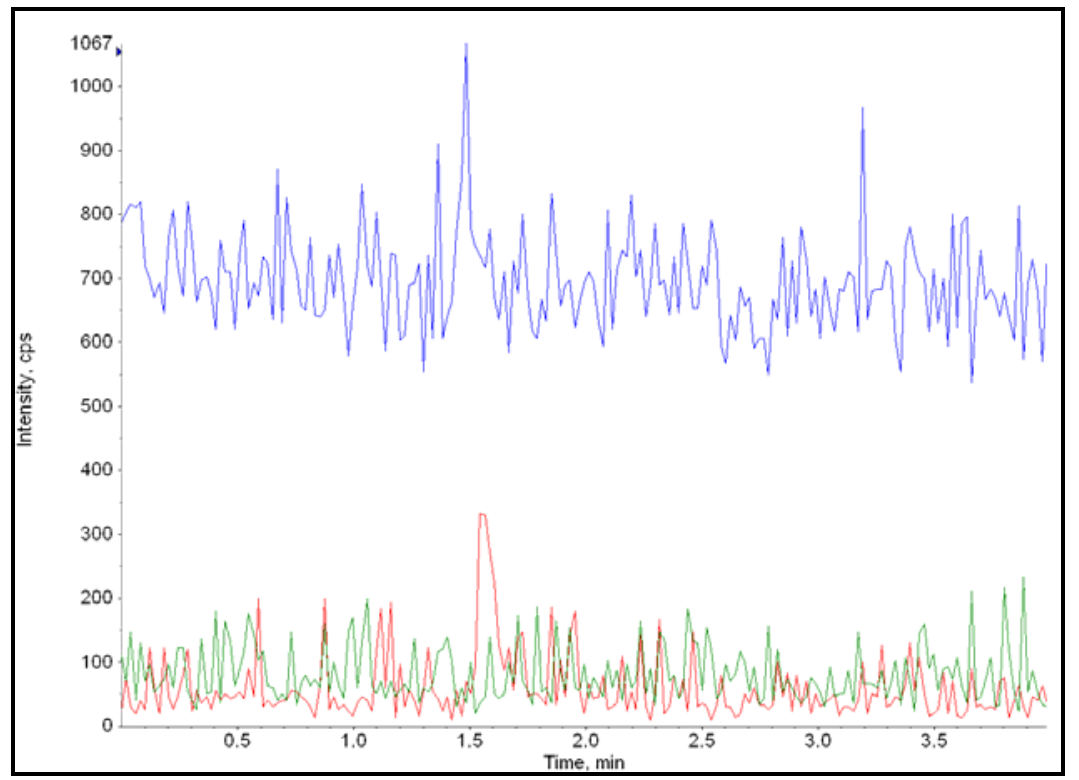

Figura 25 - Cromatograma do branco do procedimento completo por LC/MS/MS, nas condições descritas no item 4.1.

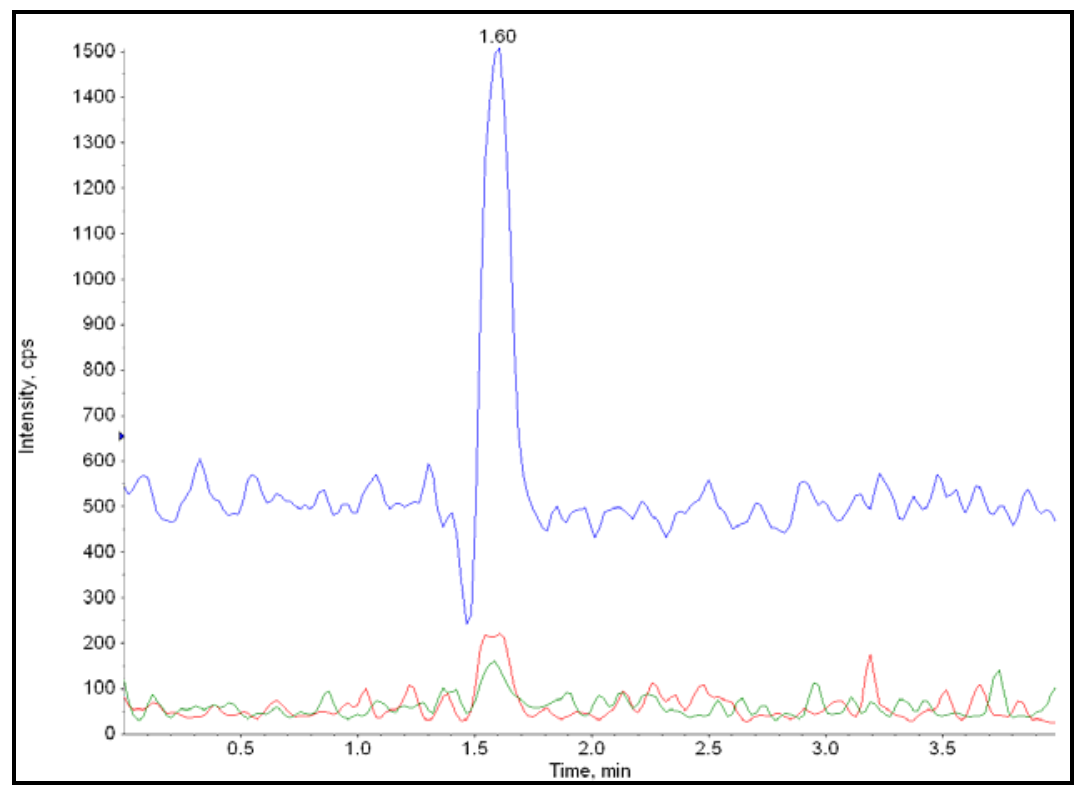

Figura 26 - Cromatograma do padrão de ETU na concentração de 1,0

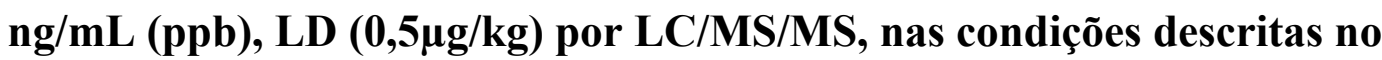
item 4.1. 


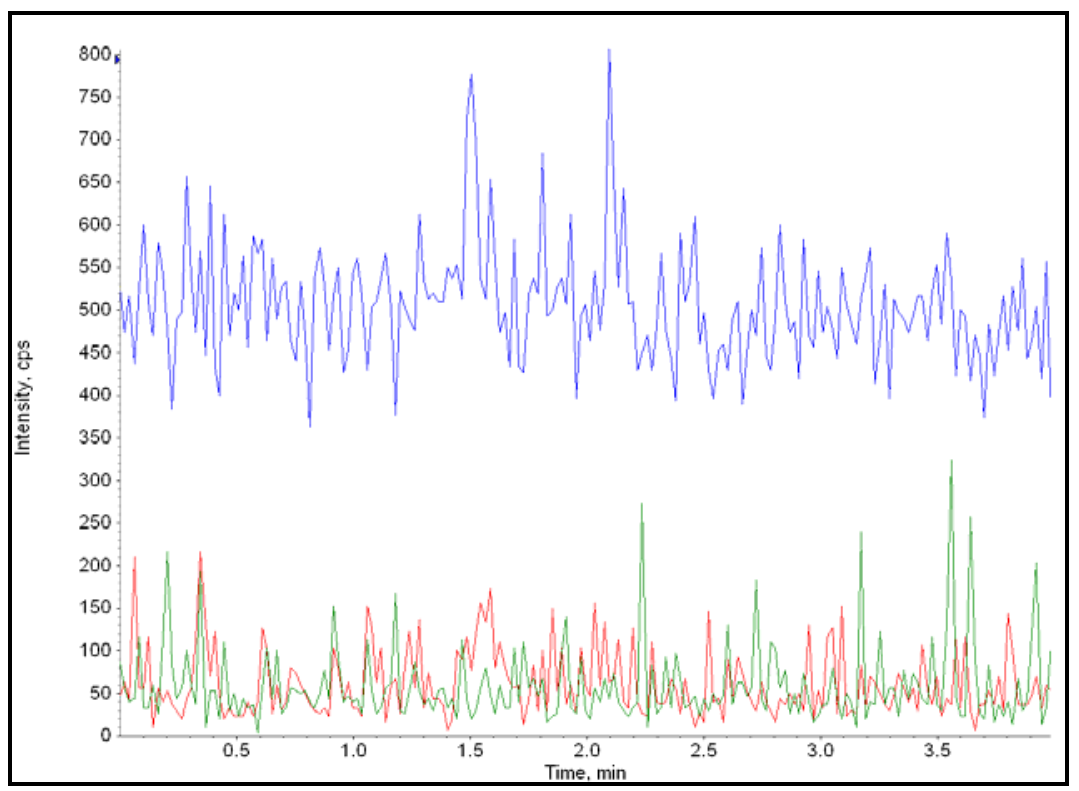

Figura 27 - Cromatograma da amostra controle de maçã por LC/MS/MS, nas condições descritas no item 4.1.

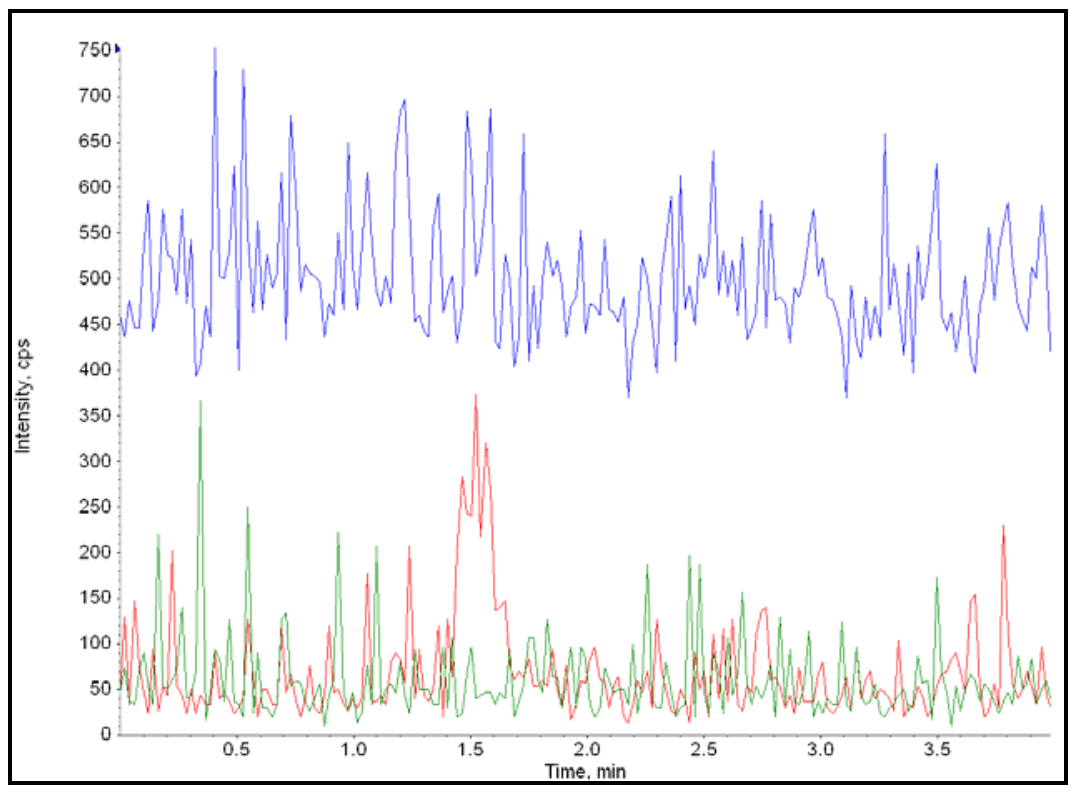

Figura 28 - Cromatograma da amostra controle de morango, nas condições descritas no item 4.1 


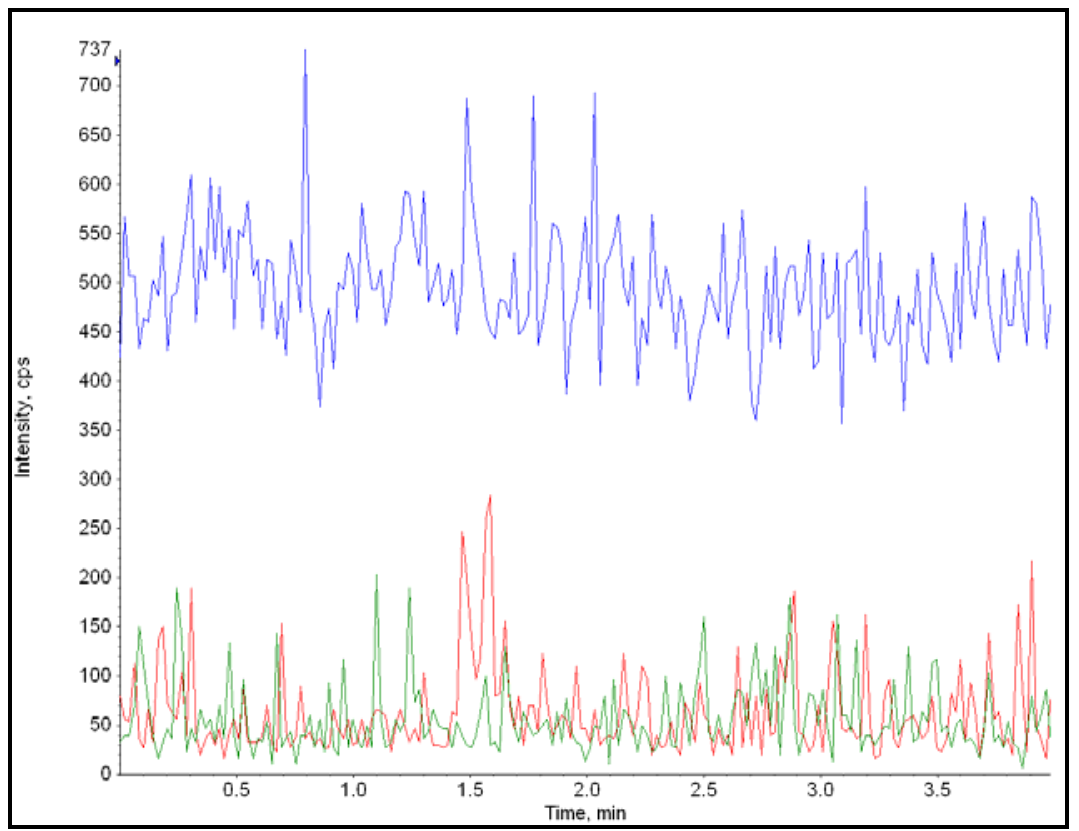

Figura 29 - Cromatograma da amostra controle de mamão por LC/MS/MS, nas condições descritas no item 4.1.

\section{- Linearidade}

Os quatro outliers diagnosticados pelo teste de resíduos padronizados Jacknife foram excluídos. A Figura 30 ilustra os gráficos exploratórios dos resíduos da regressão com indicação dos outliers tratados.

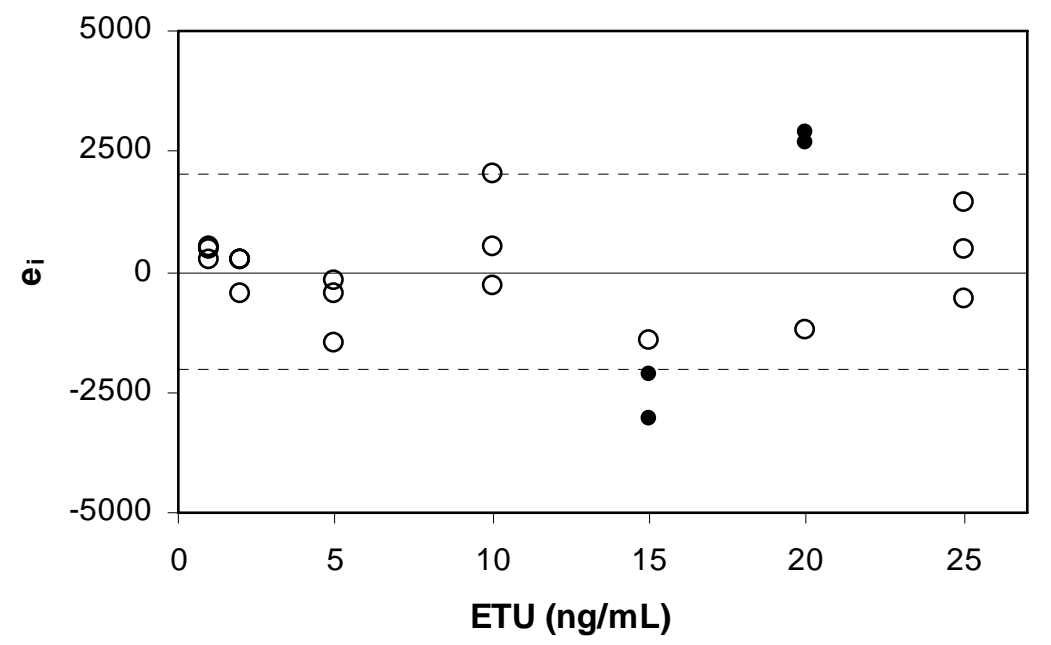

$e_{i}=$ resíduo da regressão, $\bullet=$ outlier, $\ldots= \pm t_{(1-\alpha / 2 ; n-2)} S_{\text {res }}$

Figura 30 - Gráfico exploratório dos resíduos da regressão da curva de ETU $(1,0 \mathrm{ng} / \mathrm{mL}$ a $25,0 \mathrm{ng} / \mathrm{mL})$ em solventes, com indicação dos respectivos outliers diagnosticados pelo teste de resíduos padronizados Jacknife 
O gráfico de Ryan-Joiner ilustrado na Figura 31 indica correlação significativa entre os resíduos da regressão obtidos para a curva e os valores normais teoricamente esperados, demonstrando que o desvio da distribuição normal não foi significativo, com coeficiente de correlação de $0,9747(p>0,10)$.

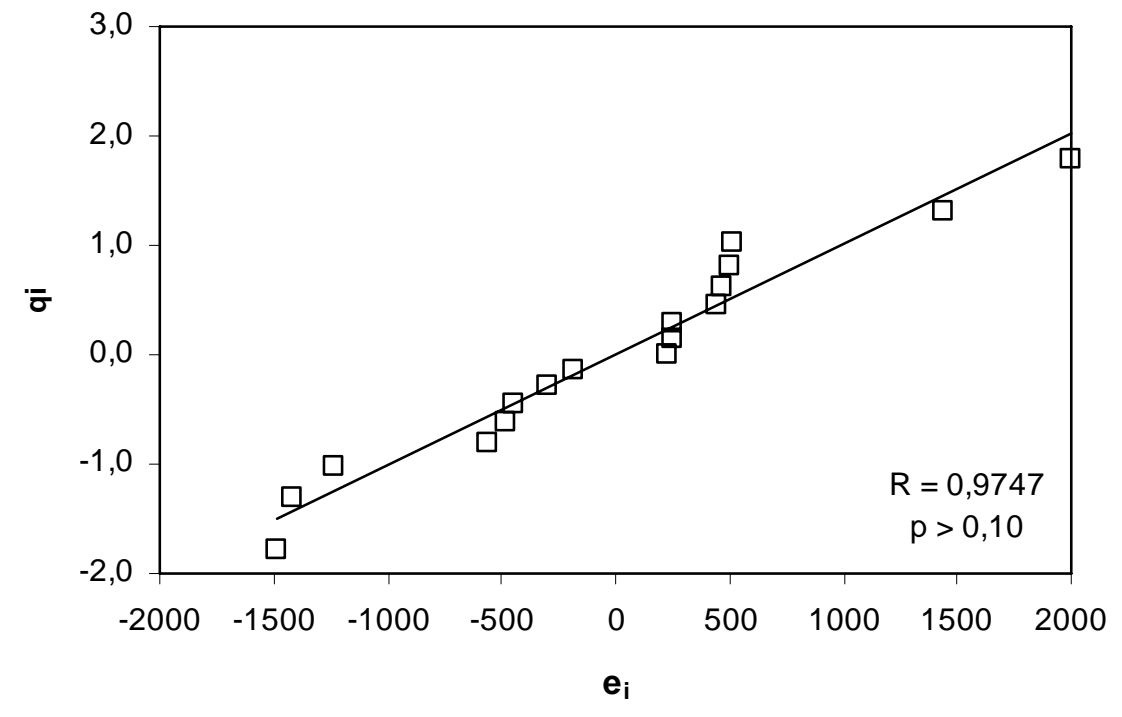

$e_{i}=$ resíduo da regressão, $q_{i}=$ valor normal esperado, $R=$ coeficiente de correlação de Ryan-Joiner, $p=$ significância.

Figura 31 - Gráfico de probabilidade normal da curva de ETU $(1,0 \mathrm{ng} / \mathrm{mL}$ a $25,0 \mathrm{ng} / \mathrm{mL}$ ) em solventes e matrizes

A premissa de homoscedasticidade dos resíduos da regressão foi confirmada. A estatística t de Levene, estimada em -1,043, não foi significativa ( $p>0,05)$.

Houve independência dos resíduos da regressão. A estatística de DurbinWatson calculada, 2,056 ( $p>0,10)$, sugeriu que não houve autocorrelação (Figura 32). 


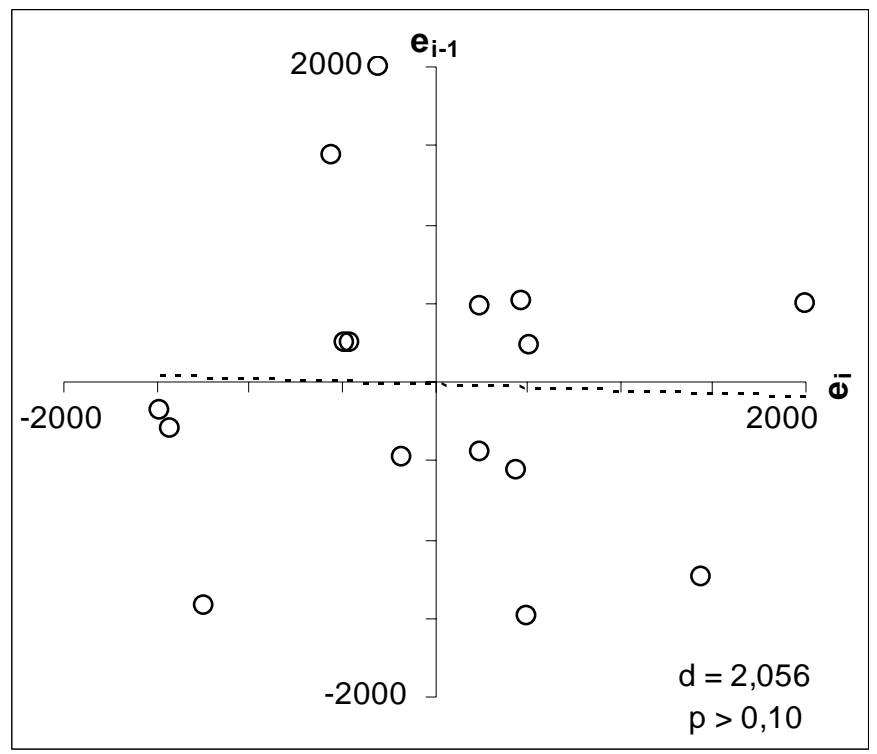

$e_{i}=$ resíduo da regressão, $d=$ estatística de Durbin-Watson, $p=$ significância.

Figura 32 - Gráfico de Durbin-Watson da curva de ETU $(1,0 \mathrm{ng} / \mathrm{mL}$ a 25,0 ng/mL) em solventes

A confirmação das três premissas indicou a possibilidade de uso de testes de hipóteses para análise dos dados obtidos e sugeriu a estimativa dos parâmetros da regressão pelo MMQO, sem necessidade de ponderações.

A regressão apresentou-se altamente significativa $(p<0,001)$ enquanto o desvio de linearidade não foi significativo $(p>0,05)$ (Tabela 19), indicando linearidade na faixa estudada de $1,0 \mathrm{ng} / \mathrm{mL}$ a $25,0 \mathrm{ng} / \mathrm{mL}$. A curva de calibração com a respectiva equação e coeficiente de determinação está ilustrada na Figura 33.

Tabela 19 - Estatísticas da análise de variância da regressão, incluindo teste de desvio da linearidade, para curva de ETU $(1,0 \mathrm{ng} / \mathrm{mL}$ a $25,0 \mathrm{ng} / \mathrm{mL}$ ) em solventes

\begin{tabular}{lcccccc}
\hline \hline \multicolumn{1}{c}{$\boldsymbol{F} . \boldsymbol{V} \boldsymbol{.}$} & $\boldsymbol{G . L .}$ & $\boldsymbol{S . Q}$. & $\boldsymbol{Q} . \boldsymbol{M}$. & $\boldsymbol{F}$ & $\boldsymbol{p}$ & Significância \\
\hline Regressão & 1 & $2,94 \mathrm{E}+10$ & $2,94 \mathrm{E}+10$ & $3,199 \mathrm{E}+04$ & $2,18 \mathrm{E}-26$ & $\mathrm{p}<0,001$ \\
Resíduo & 15 & $1,38 \mathrm{E}+07$ & $9,20 \mathrm{E}+05$ & & & \\
\hline FaltaAjuste & 6 & $7,77 \mathrm{E}+06$ & $1,30 \mathrm{E}+06$ & 1,933 & 0,18 & $\mathrm{p}>0,05$ \\
Erro puro & 9 & $6,03 \mathrm{E}+06$ & $6,70 \mathrm{E}+05$ & & & \\
\hline \hline Total & 16 & $2,94 \mathrm{E}+10$ & & & &
\end{tabular}

F.V.= fonte de variação; G.L.= grau de liberdade; S.Q.= soma dos quadrados; Q.M.= quadrado médio. $F=$ razão entre as variâncias; $\mathrm{p}=$ significância. 
- Intervalo linear de trabalho no LC/MS/MS

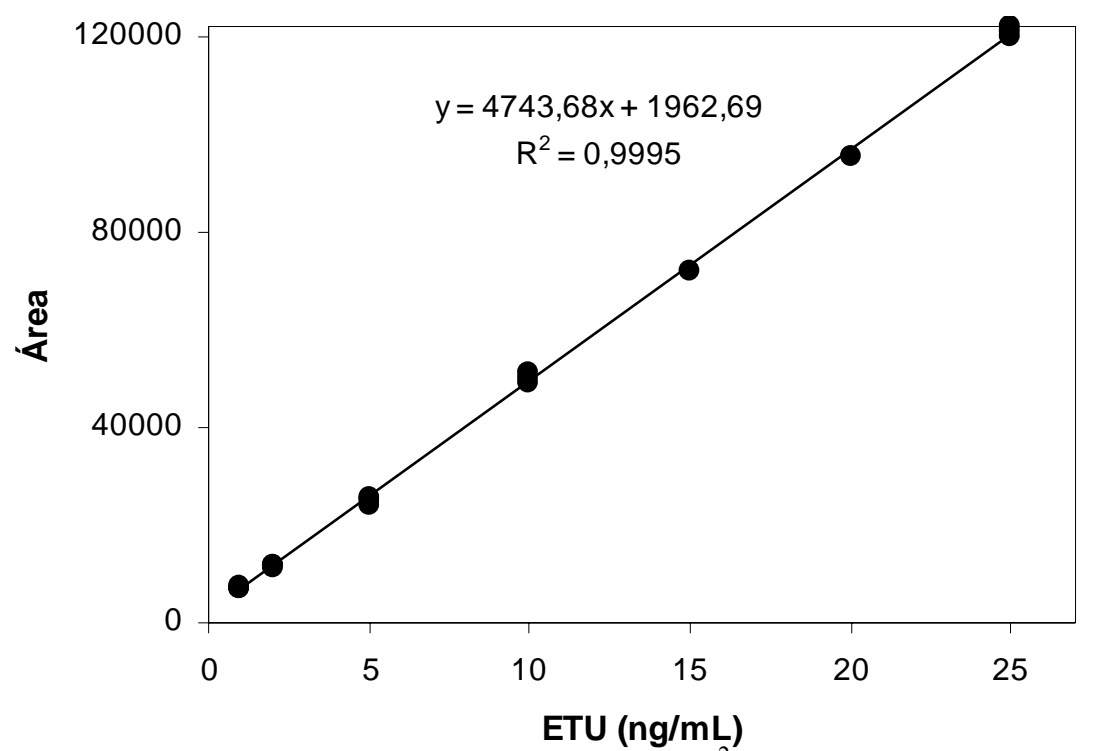

$y=$ resposta, $x=$ concentração de ETU em $\mathrm{ng} / \mathrm{mL}, R^{2}=$ coeficiente de determinação

Figura 33 - Curva analítica de ETU (transição de quantificação: 103,1> 44,0 ), na faixa de $1,0 \mathrm{ng} / \mathrm{mL}$ a $25,0 \mathrm{ng} / \mathrm{mL}$, com respectivas equações e coeficientes de determinação

A curva obtida na Figura 33 foi utilizada para quantificação de resíduos de ETU.

As demais curvas (Figuras 34 e 35) são transições confirmatórias da ETU por LC/MS/MS.

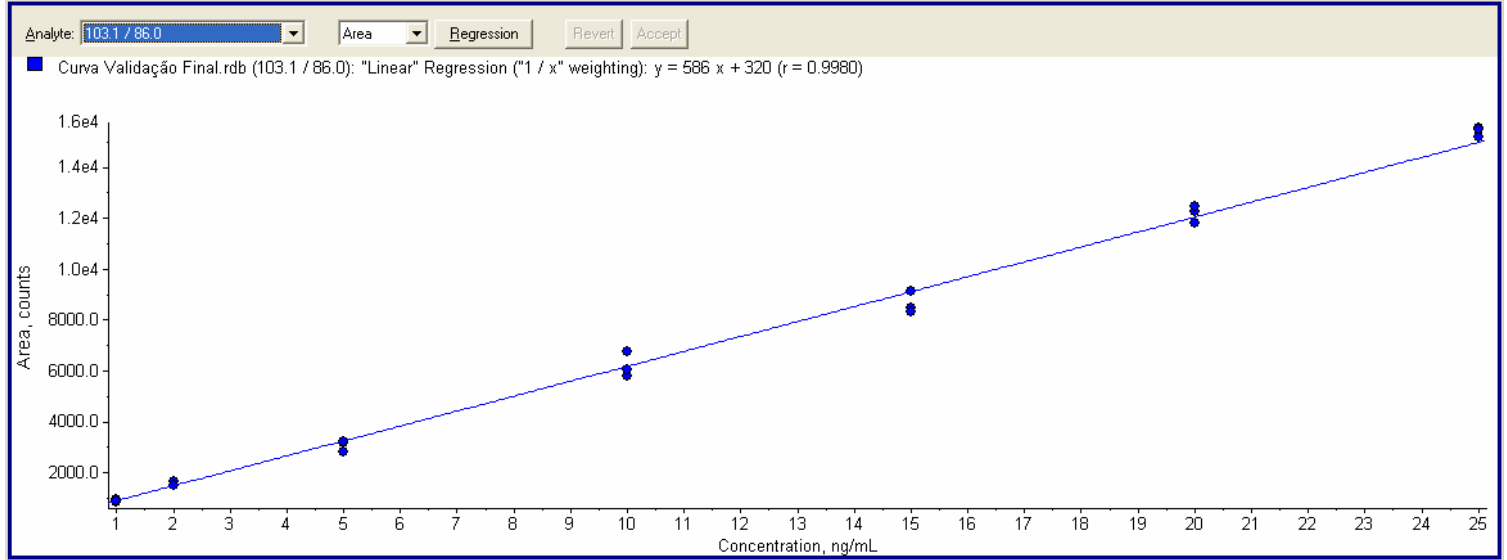

Figura 34 - Curva da Transição de Confirmação da ETU por LC/MS/MS: 103.1 $>86.0$ 


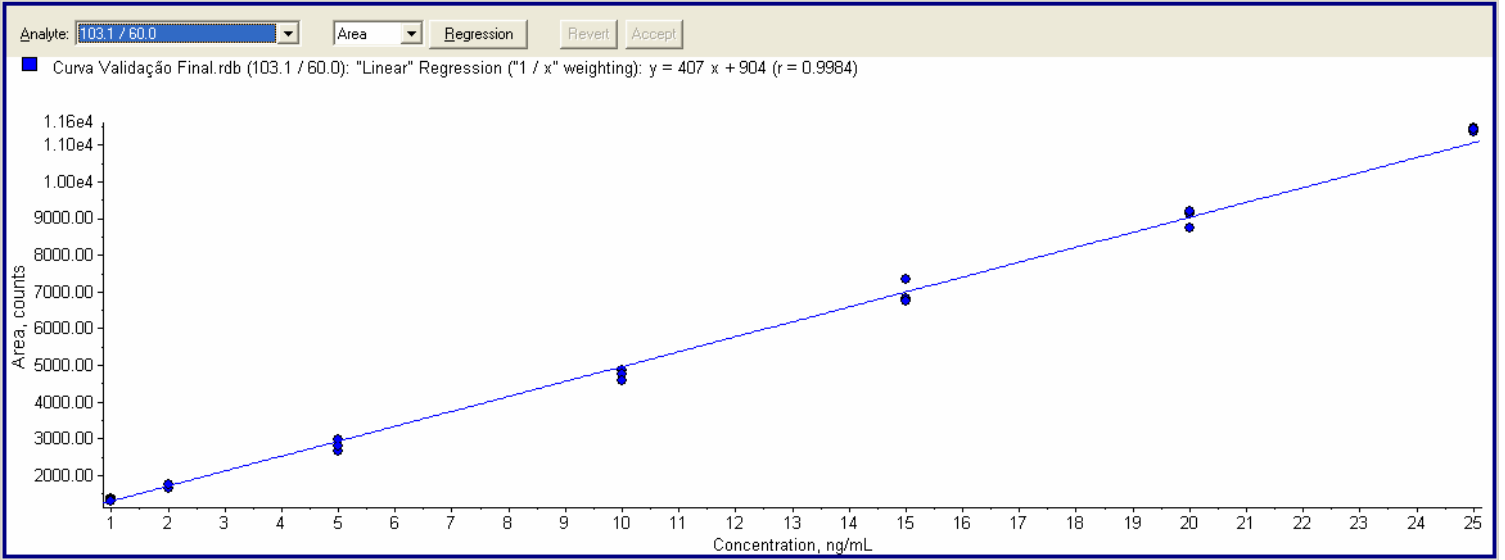

Figura 35 - Curva da 2.a Transição de Confirmação da ETU por

LC/MS/MS: $103.1>60.0$

- Intervalo de trabalho no HPLC-UV

A faixa de trabalho da curva de calibração de ETU para determinação de resíduos na análise por HPLC-UV foi de 10,0 a 250,0 ng/mL e a equação da reta $(y=0,31633 x+787780)$, conforme ilustra a Figura 36. O coeficiente de correlação foi de 0,99962, acima do valor estabelecido $(\geq 0,995)$ para análise de resíduos de agrotóxicos, conforme descrito no Manual de Resíduos e Pesticidas em Alimentos (GARP 1999).

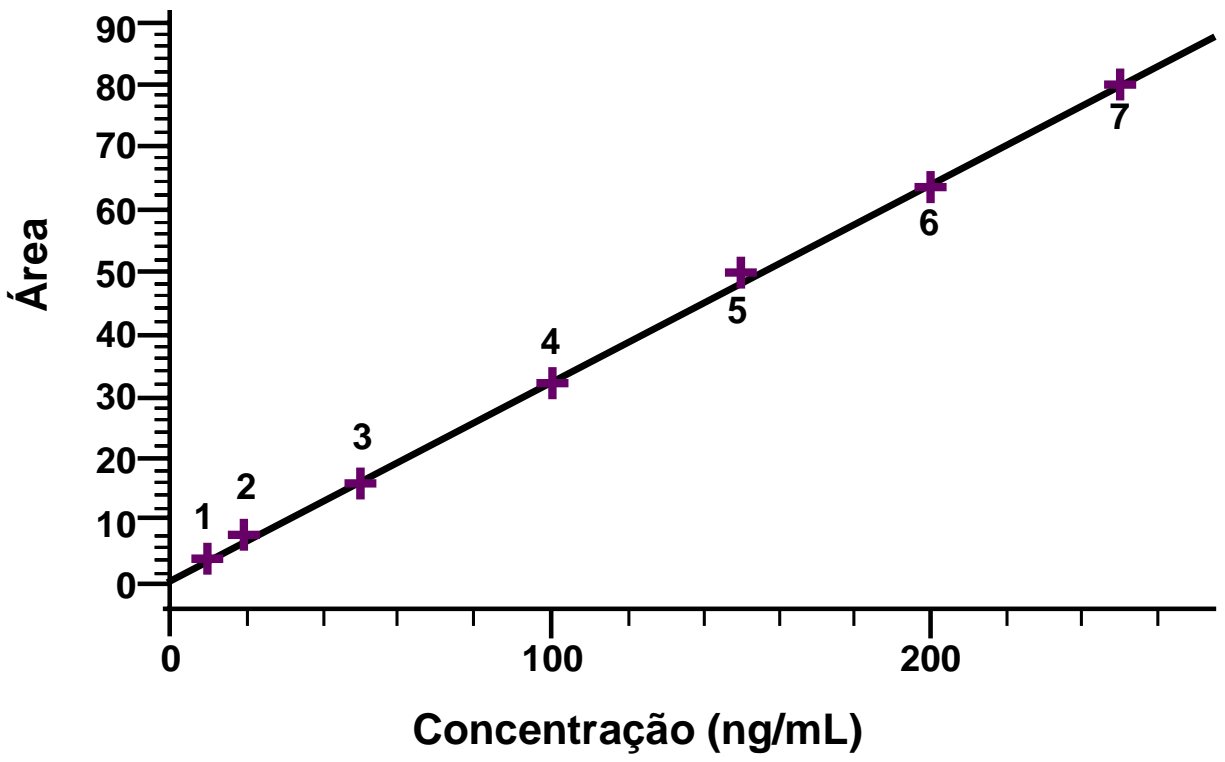

Figura 36 - Curva analítica de ETU por HPLC-UV, 10,0 a 250,0 ng/mL. 


\section{- Exatidão e Precisão}

O método para determinação de resíduos de ETU por LC/MS/MS em amostras de maçã, mamão e morango apresentou exatidão e precisão adequadas nos níveis de fortificação 1 e 2, com recuperações médias de 75 a $110 \%$ e coeficientes de variação de 13 e $17 \%$; 15 e $5 \%$ e 17 e $6 \%$, respectivamente para cada tipo de fruta estudada, conforme pode ser observado na Tabela 20.

O método de determinação de resíduos da ETU, por cromatografia a líquido acoplada à espectrometria de massas (LC/MS/MS), desenvolvido e adaptado para matrizes estudadas, mostrou-se adequado para análise de ETU nos níveis de até 2,0 $\mu \mathrm{g} / \mathrm{kg}$ para maçã e morango e de até $10,0 \mu \mathrm{g} / \mathrm{kg}$ para mamão, com recuperações médias de 75 e $110 \%$ e coeficientes de variação de 6 a 17\%. s médias das recuperações da fortificação 1, realizadas no nível do limite de quantificação do método (LQ de 1,0 $\mu \mathrm{g} / \mathrm{kg}$ ), e na fortificação 2, duas vezes o LQ $(2,0 \mu \mathrm{g} / \mathrm{kg})$ por LC/MSMS, variaram de 75 a $110 \%$ para as matrizes estudas (Tabela 20).

\section{- Estudos de recuperação}

Os resultados da análise estatística das recuperações de ETU, média, desviopadrão e coeficiente de variação para cada nível de fortificação por HPLC-UV e LC/MS/MS encontram-se na Tabela 20.

Pode-se constatar que a determinação de ETU por HPLC-UV e por LC/MS/MS, apresentou precisão adequada para todas as matrizes estudadas, uma vez que os valores dos coeficientes de variação foram menores que $20 \%$, dentro dos limites aceitáveis, estabelecidos pela ANVISA (2006).

Os limites de quantificação e de detecção de ETU por LC/MS/MS, foram respectivamente, $1,0 \mu \mathrm{g} / \mathrm{kg}$ e $0,5 \mu \mathrm{g} / \mathrm{kg}$.

Como se pode observar nas três matrizes estudadas por LC/MS/MS, o coeficiente de variação e a recuperação garantem a precisão e a exatidão necessárias para que o limite de quantificação $(1,0 \mu \mathrm{g} / \mathrm{kg})$ seja considerado aceitável e, portanto, todos os resultados das amostras adquiridas na cidade de São Paulo, neste estudo, foram quantificados por LC/MS/MS. 
Tabela 20 - Distribuição dos resultados das recuperações de ETU, desviopadrão e coeficiente de variação $(n=6)$ de acordo com o nível de fortificação por HPLC e LC/MS/MS

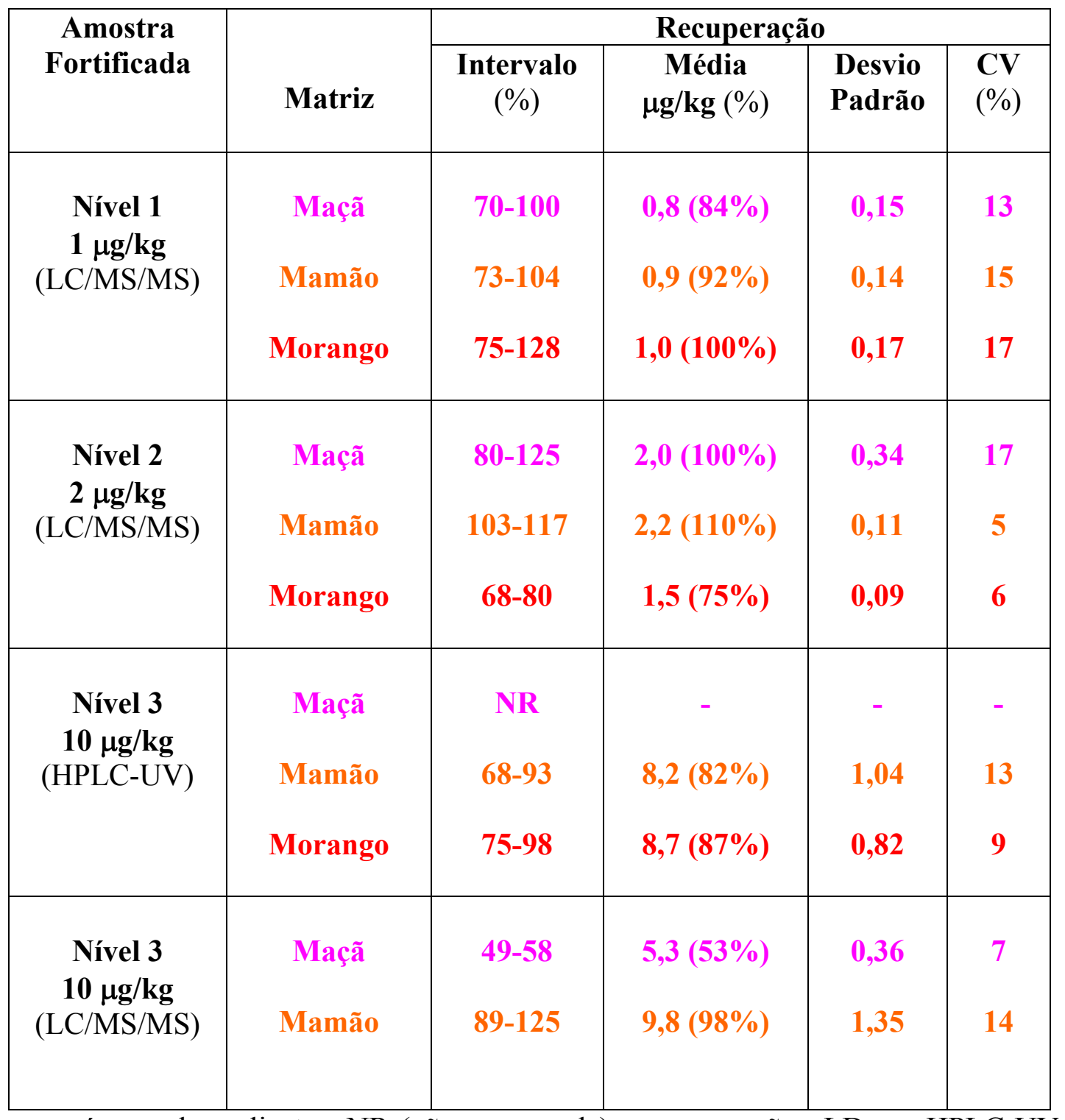

n= número de replicatas; NR (não recuperada) = recuperação $<$ LD por HPLC-UV $(5,0 \mu \mathrm{g} / \mathrm{kg}) ; \mathrm{LQ}$ no HPLC-UV=10,0 $\mu \mathrm{g} / \mathrm{kg} ;$ LQ no LC/MS $/ \mathrm{MS}=1,0 \mu \mathrm{g} / \mathrm{kg}$

As médias das recuperações em mamão para os três níveis estudados (1, 2 e $10 \mathrm{LQ}$ ), por LC/MS/MS, variaram de 92 a $110 \%$, com coeficientes de variação aceitáveis, entre 5 e $15 \%$.

O método para determinação de resíduos de ETU em amostras de mamão e morango por HPLC-UV, no nível de $10,0 \mu \mathrm{g} / \mathrm{kg}$, apresentou recuperações médias de 82 e $87 \%$, com ecoeficiente de variação de 9 e 13\%, respectivamente, conforme 
pode ser observado na Tabela 20. As amostras fortificadas de maçã não apresentaram recuperação no nível de 10,0 $\mu \mathrm{g} / \mathrm{kg}$, não sendo considerado, portanto, como LQ para esta matriz. Este valor foi considerado apenas para análise qualitativa.

\section{- Reprodutibilidade interna}

O método para determinação de ETU apresentou uma boa reprodutibilidade interna, verificada por comparação com estudos de recuperação de ETU em mamão realizados em estudo anterior, em 3 níveis de fortificação (1, 2 e 10 vezes LQ), 3 repetições cada, com recuperações médias de 80 e 110 \% e coeficientes de variação de 4 a $13 \%$, dentro dos limites aceitáveis (LEMES 2003).

\section{- Reprodutibilidade externa}

Em relação à reprodutibilidade externa, não são conhecidos programas interlaboratorias de análise de ETU, apenas de ditiocarbamatos, incluindo os EBDC. O laboratório de Resíduos de Pesticidas do Instituto Adolfo Lutz participa do Programa Interlaboratorial de Análise de ditiocarbamatos (incluindo os EBDC) e os resultados encontrados têm sido satisfatórios e comparáveis com os resultados de outros laboratórios.

\section{- Robustez}

O método para determinação de ETU por HPLC-UV, utilizado neste estudo, com algumas alterações nas condições de análise, como mudança de fase estacionária e diferentes sistemas de detecção, demonstrou boa robustez, apresentando exatidão e precisão satisfatórias e média de recuperações no nível de 10 $\mu \mathrm{g} / \mathrm{kg}$ nas matrizes de mamão e de morango, entre 82 e 87 \% (Tabela 20).

Entretanto, as recuperações realizadas em maçã, no nível de $10 \mu \mathrm{g} / \mathrm{kg}$ no LC/MS/MS, variaram de 49 a 58\% com CV de 7\%, evidenciando diminuição média de $47 \%$ do valor de ETU adicionado. Outros autores têm reportado níveis baixos de recuperação de ETU em algumas amostras de frutas, como Blasco e col. (2004) que estudaram método para determinação de ditiocarbamatos e metabólitos em laranja, por cromatografia a líquido - espectrometria de massa (modo SIM), e obtiveram a média e o desvio padrão da recuperação de ETU no nível de $0,25 \mathrm{mg} / \mathrm{kg}$ de 52,5\% e $10 \%$, respectivamente. 
É necessário um estudo mais aprofundado para avaliar se a perda nos estudos de recuperação ao nível de $10 \mu \mathrm{g} / \mathrm{kg}$ se deve à interação dos resíduos de EBDC e da ETU ou de outro componente utilizado no tratamento da fruta com a matriz (maçã) ou devido à condições ambientais como temperatura, por exemplo. $\mathrm{O}$ ideal seria estudar simultaneamente os EBDC e ETU para melhor avaliação do que ocorre.

\section{- Limites de detecção e de quantificação}

O limite de detecção no LC/MS/MS foi de $0,5 \mu \mathrm{g} / \mathrm{kg}$ e o de quantificação foi de $1,0 \mu \mathrm{g} / \mathrm{kg}$ para as três matrizes estudadas (maçã, mamão e morango) no LC/MS/MS. Na Figura 37 encontra-se um cromatograma de padrão de ETU na concentração de 2,0 ng/mL, correspondente ao LQ $(1,0 \mu \mathrm{g} / \mathrm{kg})$ do método.

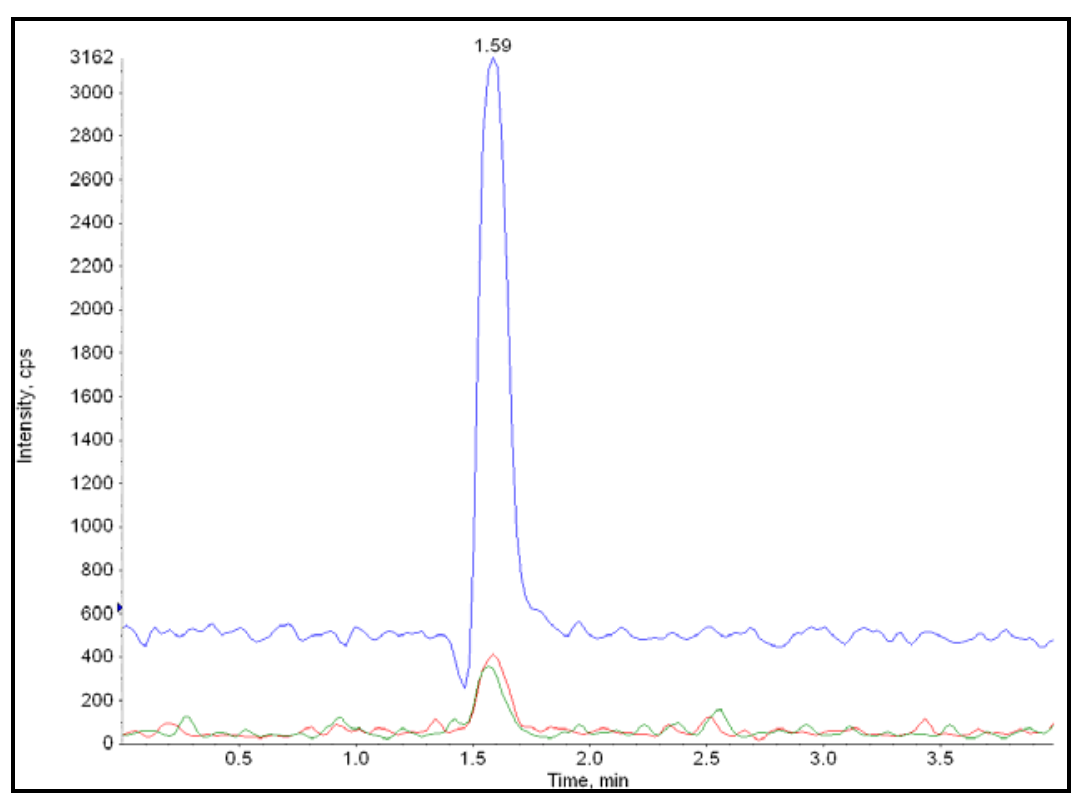

Figura 37 - Cromatograma do padrão de ETU na concentração de 2,0 $\mathrm{ng} / \mathrm{mL}$ (ppb), LD (1,0 $\mu \mathrm{g} / \mathrm{kg})$ por LC/MS/MS, nas condições descritas no item 4.1 


\subsection{Resíduos de etilenotiouréia (ETU) em frutas comercializadas na cidade de São Paulo}

A determinação de ETU foi feita por HPLC-UV e LC/MS/MS, após execussão do procedimento experimental proposto por Diserens (1991), com adaptações (LEMES 2003), conforme descrito no item 3.2.

\section{- Determinação por HPLC-UV}

Foi constatada a presença de resíduos de ETU em 27 (30\%) das 90 amostras de frutas analisadas no HPLC-UV, porém em níveis abaixo do LQ $(10,0 \mu \mathrm{g} / \mathrm{kg})$ do método. Foram detectados níveis de ETU em 9 (30\%) das amostras de maçã, em 18 (60\%) de mamão e em nenhuma das amostras de morango.

Como os resultados das amostras adquiridas na cidade de São Paulo analisadas por HPLC-UV estavam abaixo do LQ ou do LD do método, as quantificações foram realizadas no LC/MS/MS que apresentou limite de quantificação dez vezes menor $(1,0 \mu \mathrm{g} / \mathrm{kg})$ para as matrizes estudadas. Todos os resultados individuais por local e estação encontram-se nos anexos 1, 2, 3 .

\section{- Determinação por LC/MS/MS}

Foram encontrados resíduos de ETU em 32 (35\%) das 90 amostras de frutas analisadas, sendo 10 (33\%) das amostras de maçã em níveis que variaram de 1,0 a

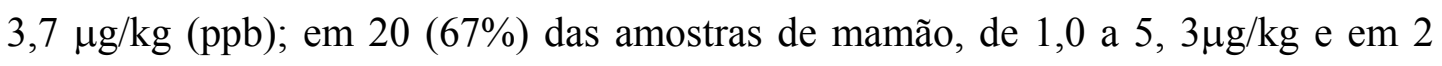
(7\%) das amostras de morango, de 1,0 a 1,4 $\mu \mathrm{g} / \mathrm{kg}$, conforme pode ser observado na Tabela 21.

Nas Figuras 38 e 39 estão apresentados exemplos de cromatogramas de amostras nas quais foram encontrados resíduos de ETU. 


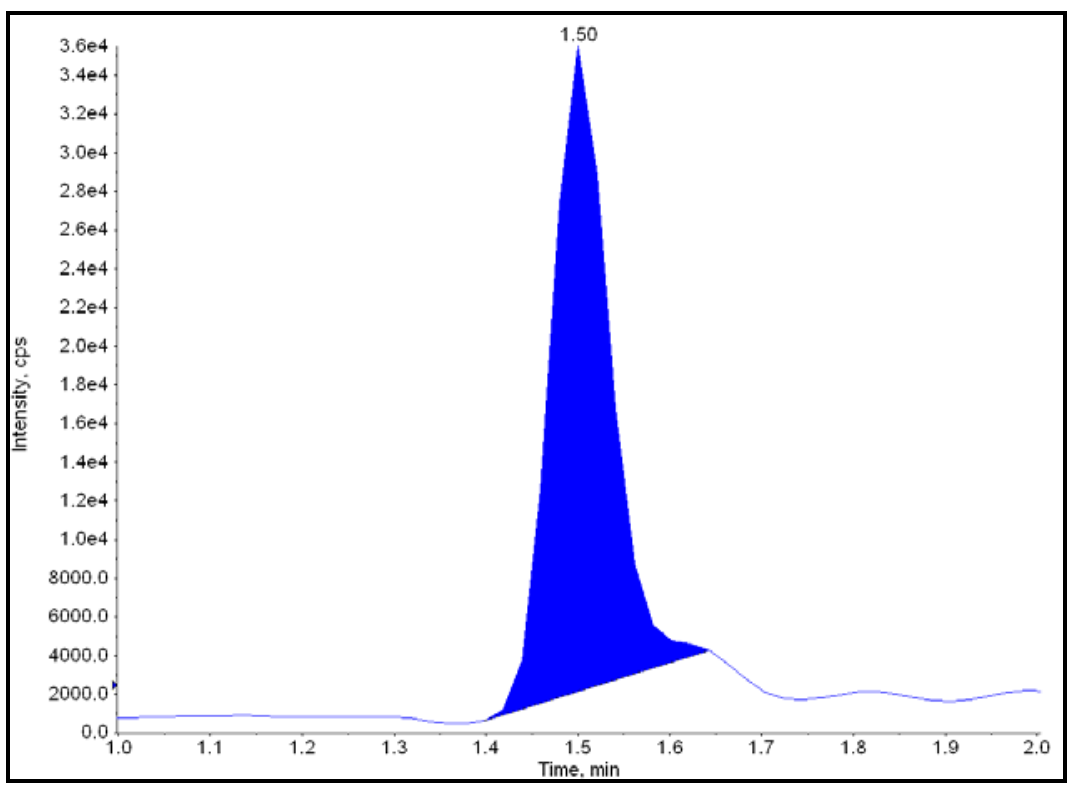

Figura 38 - Cromatograma da amostra de maçã com $3,7 \mu \mathrm{g} / \mathrm{kg}$ de ETU (anexo 3), analisada por LC/MS/MS

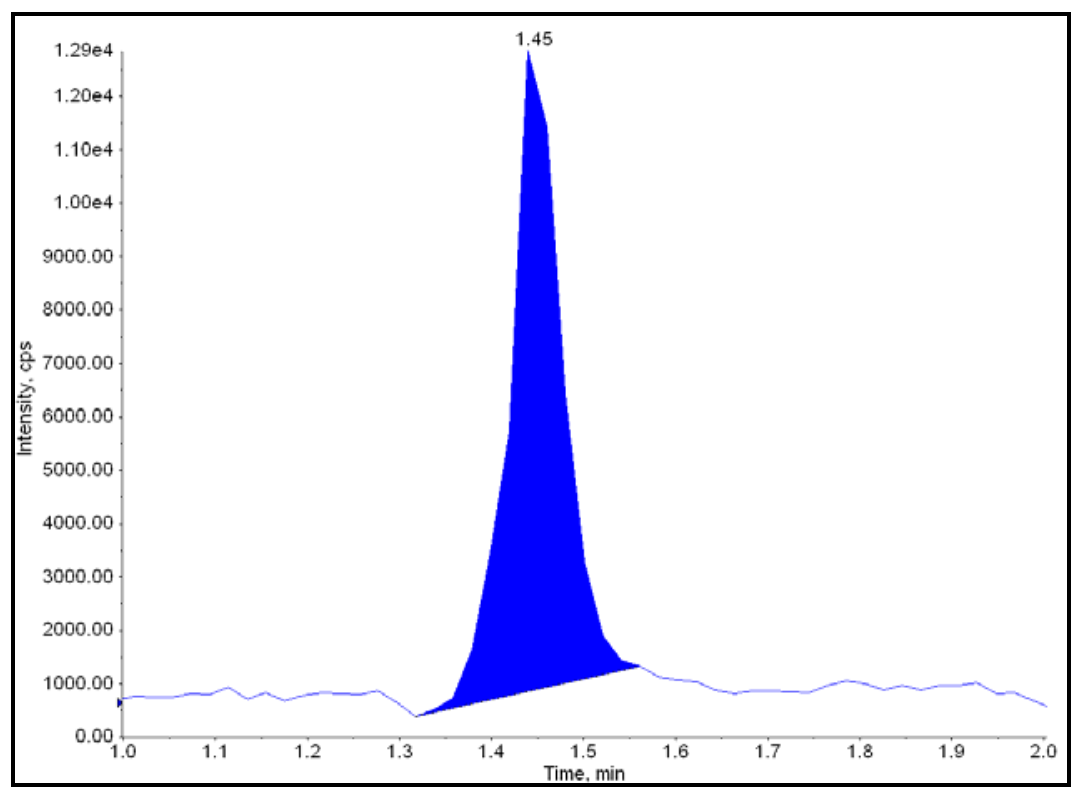

Figura 39 - Cromatograma da amostra de morango com $1,4 \mu \mathrm{g} / \mathrm{kg}$ de ETU (anexo 5), analisada por LC/MS/MS 
Tabela 21 - Número (N) e porcentagem (\%) de amostras com resíduos de ETU, mediana, média, desvio-padrão (DP), média geométrica e valores mínimos e máximos por LC/MS/MS

\begin{tabular}{|c|c|c|c|c|c|c|c|c|}
\hline \multicolumn{3}{|c|}{ Amostras } & \multicolumn{6}{|c|}{ Resíduos de ETU } \\
\hline & $\begin{array}{c}<\mathbf{L Q} \\
\mathbf{N} \\
(\%)\end{array}$ & $\begin{array}{c}\text { > LQ } \\
\text { N } \\
(\%)\end{array}$ & $\begin{array}{c}\text { Mediana } \\
(\mu \mathrm{g} / \mathrm{kg})\end{array}$ & $\begin{array}{l}\text { Média } \\
(\mu \mathrm{g} / \mathrm{kg})\end{array}$ & DP & $\begin{array}{l}\text { CV } \\
(\%)\end{array}$ & $\begin{array}{c}\text { Media } \\
\text { geométric } \\
\mathbf{a} \\
(\mu \mathrm{g} / \mathrm{kg})\end{array}$ & $\begin{array}{c}\text { mínimo } \\
\text { máximo } \\
(\mu \mathrm{g} / \mathrm{kg})\end{array}$ \\
\hline $\begin{array}{l}\text { Maçã } \\
(\mathrm{n}=\mathbf{3 0})\end{array}$ & $\begin{array}{c}20 \\
(67 \%)\end{array}$ & $\begin{array}{c}10 \\
(33 \%)\end{array}$ & 0,5 & 1,0 & 0,9 & 90 & 0,8 & $1,0-3,7$ \\
\hline $\begin{array}{l}\text { Mamão } \\
(\mathrm{n}=30)\end{array}$ & $\begin{array}{c}10 \\
(33 \%)\end{array}$ & $\begin{array}{c}20 \\
(67 \%)\end{array}$ & 1,6 & 1,3 & 1,2 & 92 & 1,2 & $1,0=5,3$ \\
\hline $\begin{array}{c}\text { Morango } \\
(\mathrm{n}=\mathbf{3 0})\end{array}$ & $\begin{array}{c}28 \\
(93 \%)\end{array}$ & $\begin{array}{c}2 \\
(7 \%)\end{array}$ & 0,5 & 0,5 & 0,2 & 40 & 0,5 & $1,0-1,4$ \\
\hline $\begin{array}{l}\text { Total } \\
(\mathrm{n}=90)\end{array}$ & $\begin{array}{c}58 \\
(65 \%)\end{array}$ & $\begin{array}{c}32 \\
(35 \%)\end{array}$ & 0,5 & 0,8 & 1,0 & 125 & 0,8 & $1,0-5,3$ \\
\hline
\end{tabular}

OBs.: Para os cálculos estatísticos, as amostras não quantificadas foram consideradas com valores iguais ao limite de detecção do método de $0,5 \mu \mathrm{g} / \mathrm{kg}$.

Menor freqüência e menores valores de resíduos de ETU foram encontrados nas amostras de morango. Uma possível explicação para esta observação, fundamenta-se na alteração que houve do uso de ditiocarbamatos em cultura de morango. O uso do manebe foi substituído pelo metam sódico com LMR de 0,2 $\mathrm{mg} / \mathrm{kg}$.

As medianas de resíduos de ETU encontrados em maçã e morango foram iguais $(0,5 \mu \mathrm{g} / \mathrm{kg}$ ). O mamão apresentou uma mediana maior de $1,6 \mu \mathrm{g} / \mathrm{kg}$ (Tabela 21). 
A distribuição de todos os valores encontrados nas amostras de maçã, mamão e morango encontram-se, nas Figuras 40, 41 e 42, respectivamente.

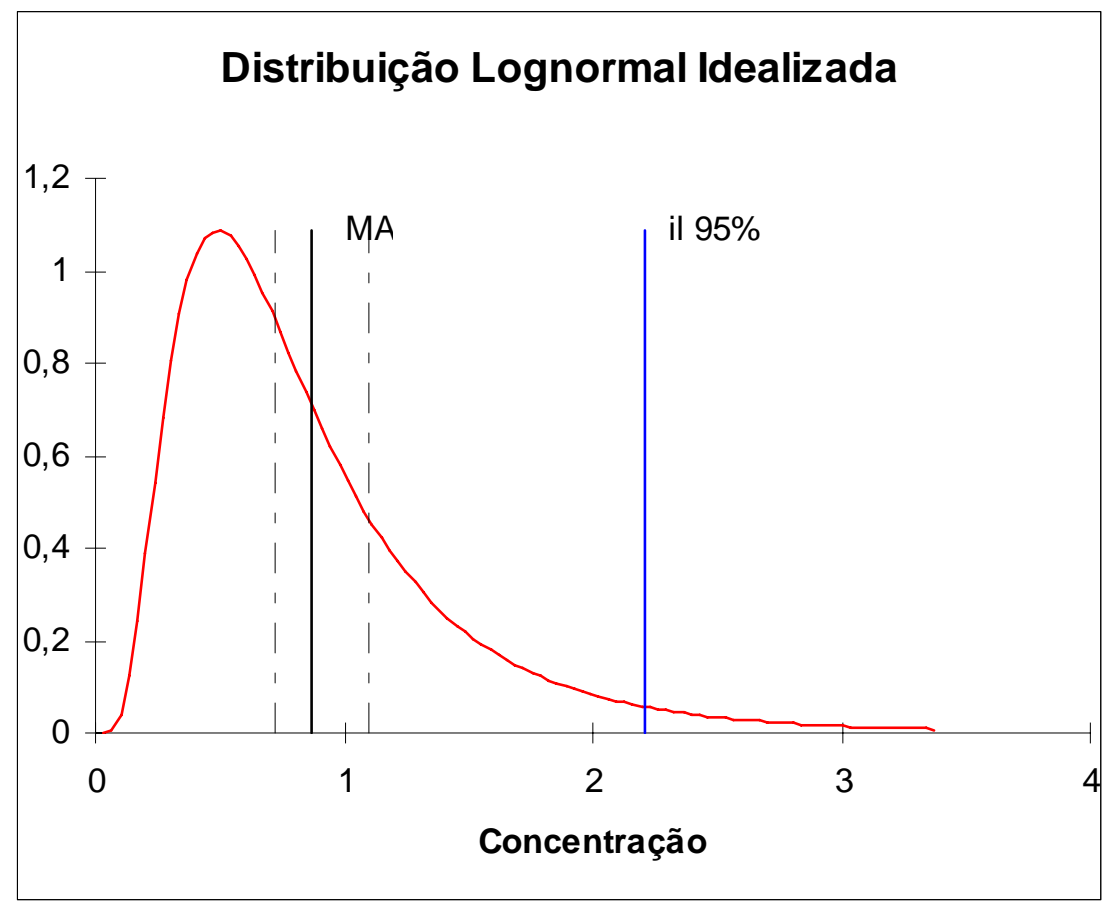

Figura 40 - Distribuição dos níveis de ETU $(\mu \mathrm{g} / \mathrm{kg})$ determinados por LC/MS/MS, encontrados nas amostras de maçã

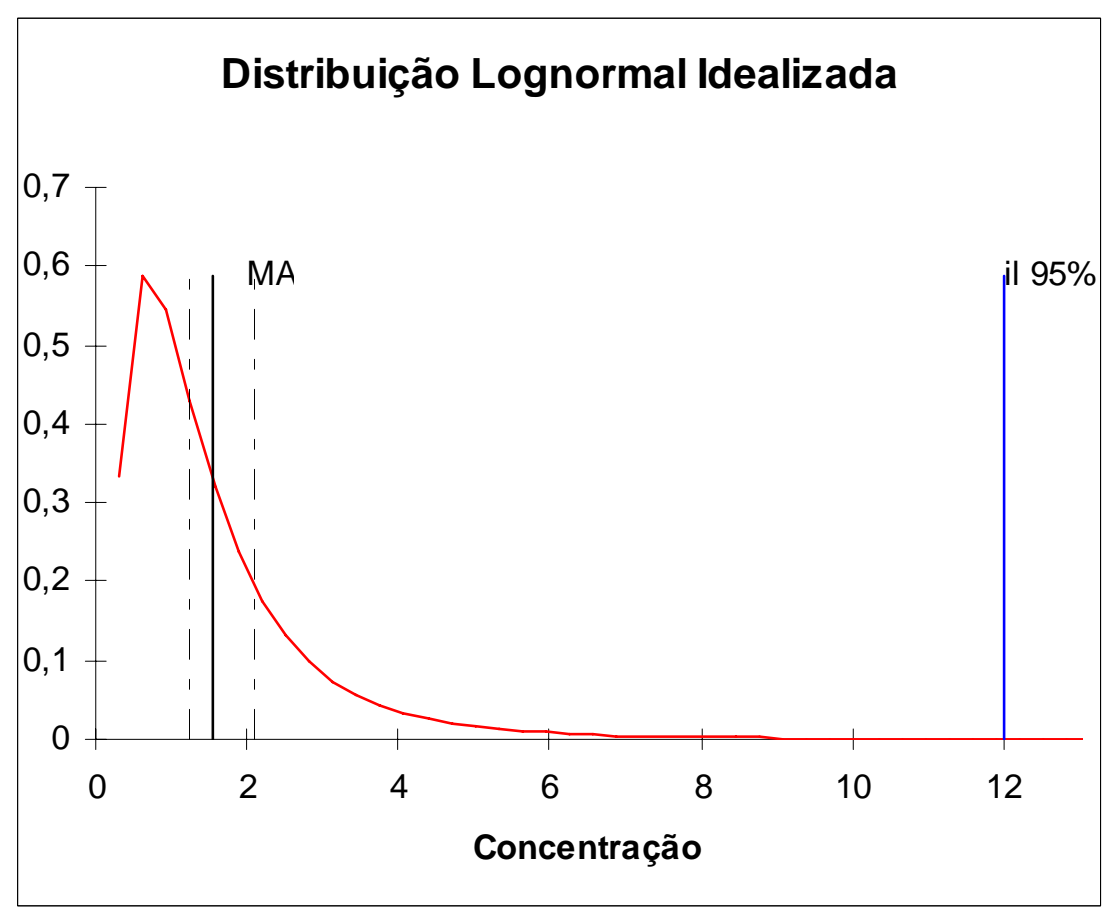

Figura 41 - Distribuição dos níveis de ETU $(\mu \mathrm{g} / \mathrm{kg})$ determinados por LC/MS/MS, encontrados nas amostras de mamão 


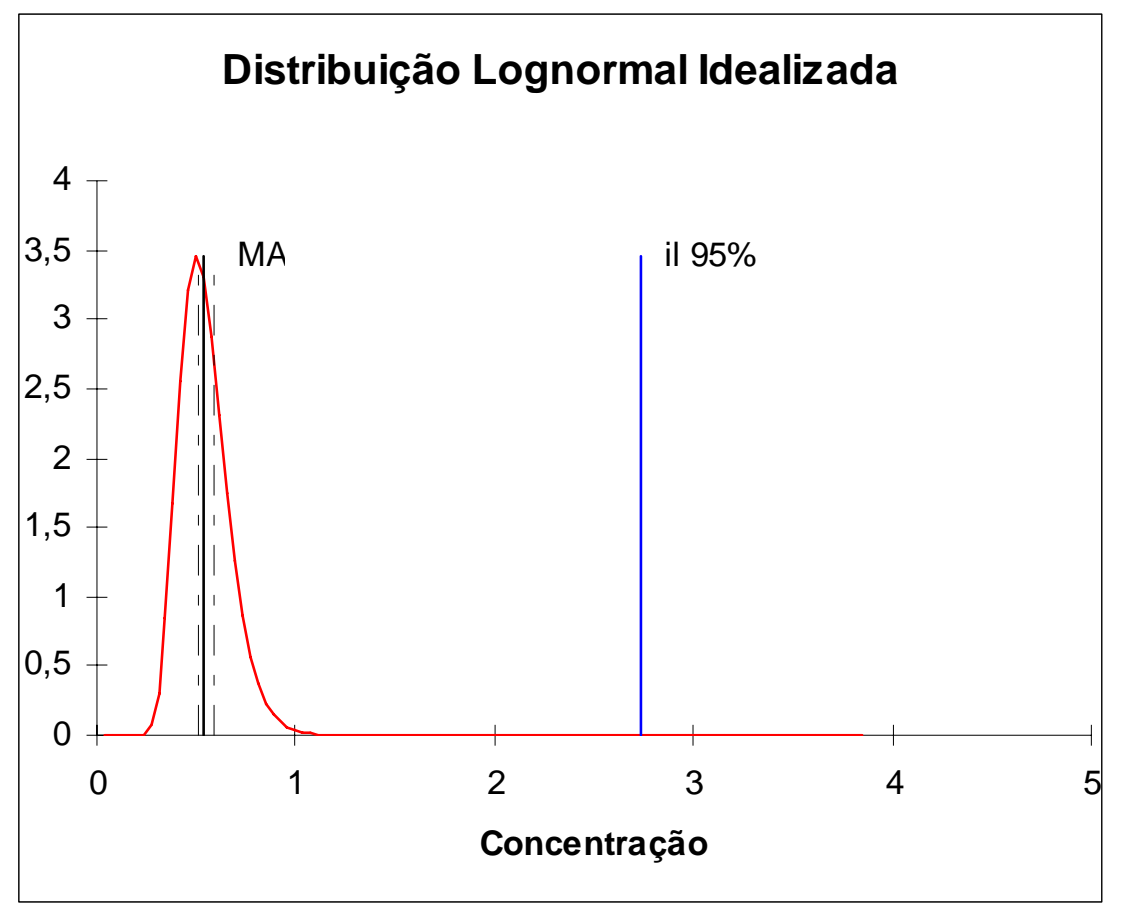

Figura 42 - Distribuição dos níveis de ETU $(\mu \mathrm{g} / \mathrm{kg})$ determinados por LC/MS/MS, encontrados nas amostras de morango

Os maiores valores de ETU, em freqüência e quantidade, foram os do mamão, o que já era esperado, pois em estudo anterior, foram encontrados resíduos de etilenotiouréia em todas as amostras de mamão tratado com $o$ etilenobisditiocarbamato (mancozebe) na dose normal de uso em níveis bem mais elevados, que variaram de 0,01 a $0,09 \mathrm{mg} / \mathrm{kg}$ (LEMES 2003).

O Brasil é um dos maiores produtores de frutas do mundo. As exigências de países importadores incluem a aquisição de alimentos com baixos níveis de resíduos de agrotóxicos e que a sua produção leve em consideração o meio ambiente e a saúde do trabalhor, fatores que têm gerado uma mudança de comportamento dos produtores e na política para exportação de alimentos. Desde que foi implantado o programa de Produção Integrada de Frutas (PIF), com a diminuição dos índices de aplicação de substâncias agroquímicas nos pomares, houve redução de $63 \%$ no uso de agrotóxicos nos pomares de manga; de 50\% nos de mamão; de $32 \%$ nos de uva; e de $30 \%$ nos de maçã (MAPA 2007e). Esta mudança de comportamento, explica, parcialmente, a diminuição dos níveis de ETU em relação aos estudos já realizados.

$\mathrm{Na}$ Figura 43 encontram-se os resultados em número e porcentagem de ocorrência de resíduos de ETU, nas amostras coletadas no período de 21 dezembro de 2005 a 19 de dezembro de 2006, de acordo com as estações do ano. 


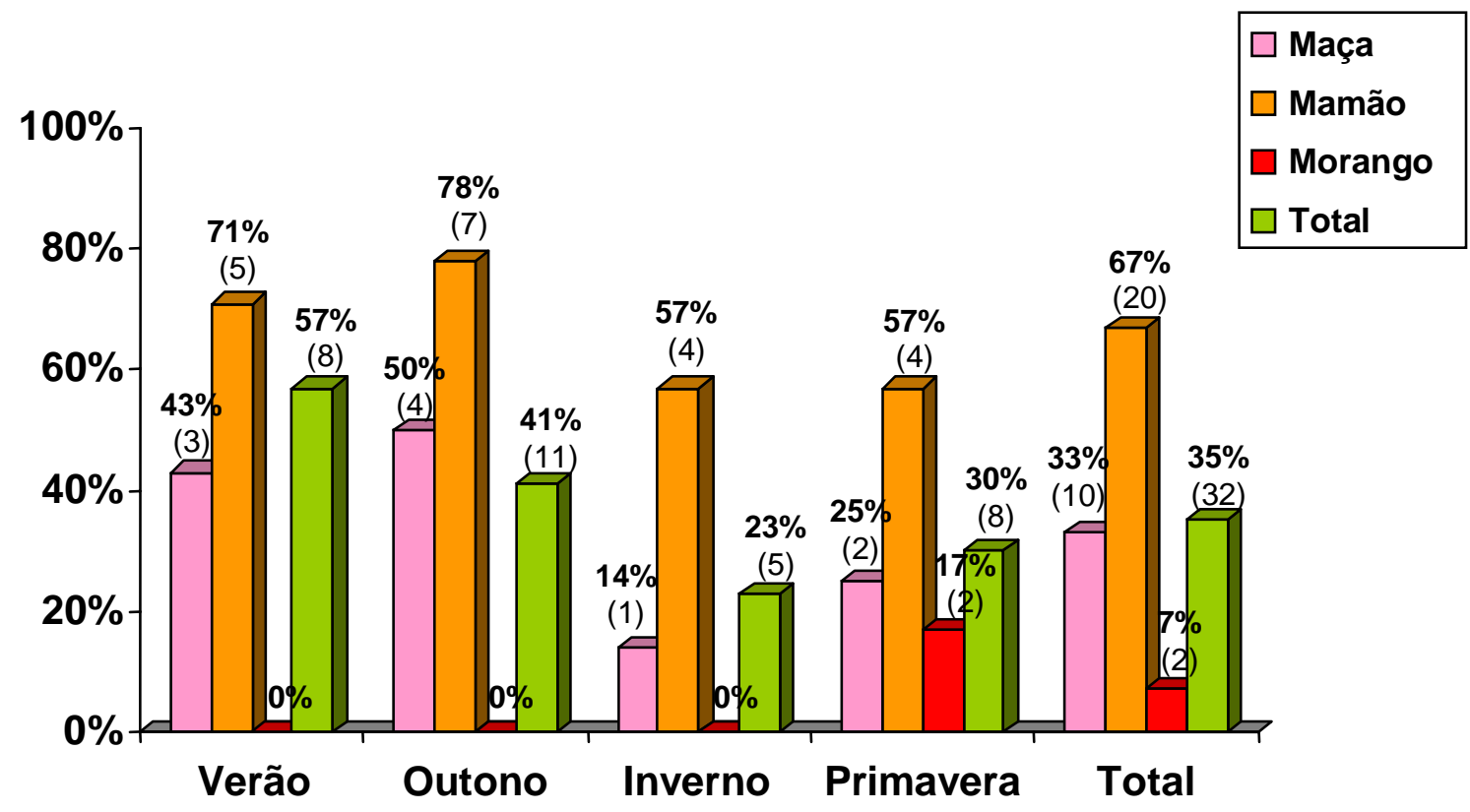

Figura 43 - Amostras (\%) com níveis de ETU > LQ de acordo com a estação do ano, no período de 21/12/2005 a 19/12/2006

De uma maneira geral, as amostras de maçã e de mamão coletadas no verão e outono apresentaram a maior porcentagem de ocorrência de resíduos de ETU do que no inverno e primavera, sendo maiores no outono (Figura 43). No período de chuvas, com maiores possibilidades de proliferação de doenças, principalmente as fúngicas, os agrotóxicos, geralmente, são aplicados com maior freqüência. Além disso, o aumento da temperatura facilita a formação de ETU. Um indicativo de comprovação do efeito da temperatura é que, para todas as matrizes analisadas, as coletadas no inverno foram as que apresentaram menor ocorrência de resíduos de ETU.

Considerando o total de amostras, as regiões que apresentaram maior freqüência de resíduos de ETU, em ordem decrescente, foram: leste (48\%); oeste (37\%); centro (31\%), sul (30\%) e norte (28\%). A maior freqüência de resíduos de ETU em maçã foi na região leste (57\%), mamão foi na região norte $(80 \%)$, e morango no centro (17\%), conforme pode-se observar na figura 44. 


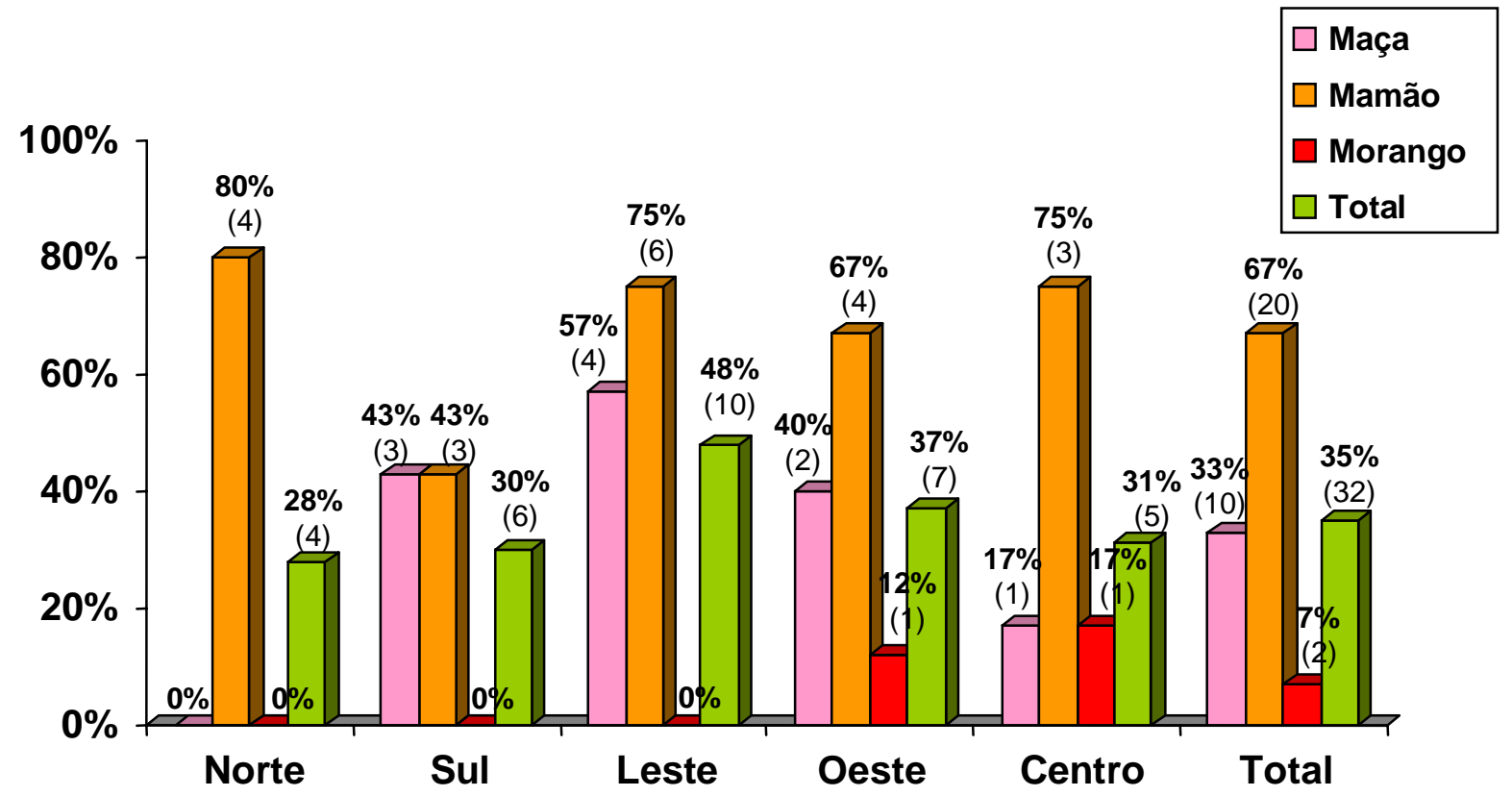

Figura 44 - Amostras (\%) com níveis de ETU de acordo com a região da cidade de São Paulo-SP, no período de 21/12/2005 a 19/12/2006

De uma maneira geral, pode-se dizer que não há diferença na freqüencia de resíduos de ETU encontrados no total das amostras adquiridas nas regiões oeste, centro, sul e norte, considerando uma variação de até $20 \%$. Somente a zona leste apresentou maior porcentagem de dados positivos. Essa independência da região onde foram adquiridas as amostras poderia ser um indicativo de que estão distribuídas de maneira razoavelmente uniforme.

Porém, quando se observa cada matriz separadamente (Figura 44), nota-se que o indicativo de maior freqüência difere de região dependendo da fruta analisada. A maior freqüência de resíduos de ETU em maçã foi encontrada na região leste (57\%); em mamão foi na região norte (80\%), e morango no centro (17\%) e, não foram encontrados resíduos de ETU nas amostras de maçã coletadas na zona norte e também nas de morango, adquiridas nas zonas norte, sul e leste, no limite de quantificação do método $(1,0 \mu \mathrm{g} / \mathrm{kg})$. Essas diferenças podem ser atribuídas a alguns fatores, como: diferentes procedências das frutas, condições de transporte, armazenamento e tempo de prateleira, custo, disponibilidade. Porém essas 
afirmações são especulatórias, só um estudo mais detalhado, incluindo a rastreabilidade, poderá fornecer uma resposta conclusiva.

Em São Paulo as frutas são geralmente adquiridas da CEAGESP, porém, grandes redes de supermercados podem ter o fornecimento direto de produtores ou distribuidores, e esta pode ser uma explicação do porquê das diferenças nos resultados entre regiões da cidade.

O tempo da aplicação até o consumo pode também gerar diferenças nos níveis encontrados. Knio e col., em 2000, com o objetivo de estudar a degradação de manebe e zinebe à ETU e a persistência de ETU em tomates cultivados em estufa, realizaram uma pesquisa com $\mathrm{C}^{14}$ e verificaram que decresceu de $0,0082 \mathrm{mg} / \mathrm{kg}$ no $1^{\mathrm{o}}$ dia para $0,023 \mathrm{mg} / \mathrm{kg}$ e $0,05 \mathrm{mg} / \mathrm{kg}$ no $20^{\circ}$ dia, para zinebe e manebe, respectivamente. Acentuada redução do conteúdo de ETU foi observada nas primeiras 24 horas após o tratamento, seguida de lento declínio nos cinco dias seguintes. O conteúdo de ETU foi reduzido para aproximadamente $80 \%$ depois de 20 dias da aplicação do fungicida, dobrando a concentração de EU, o maior produto de degradação de ETU.

No caso do morango, menor freqüência e resultados menores são um indicativo de que a mudança da legislação que cancelou o uso do manebe e autorizou o uso de metam sódico com LMR de 0,2 mg/kg (MINISTÉRIO DA SAÚDE 2003) repercutiu apenas recentemente em alteração em uso de princípio ativo, pois no Programa Paulista de Análise Fiscal de Alimentos- PP0304, realizado em 2003 e 2004, foram encontrados ditiocarbamatos em 13 (54\%) das 24 amostras de morango analisadas, com valores acima do LMR (SÃO PAULO 2005).

Entretanto, o metam sódico também causa a inibição da colinesterase. In vivo a liberação de $\mathrm{CS}_{2}$ é importante, porque sua presença é associada a neuropatias e pode ser o agente de efeitos neuropáticos causados por alguns ditiocarbamatos (EPA 2001). O JMPR e o governo brasileiro não têm ainda estabelecida a IDA para o

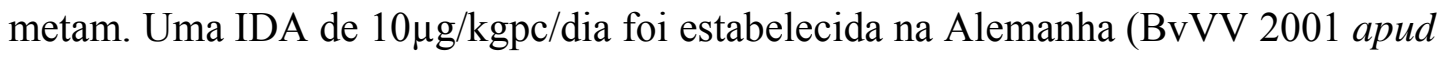
CALDAS e col. 2006). 


\subsection{Avaliação de risco de exposição à ETU pela ingestão de frutas}

Os valores encontrados neste estudo estão abaixo do valor estabelecido para alimentos pela União Européia, de $50 \mu \mathrm{g} / \mathrm{kg}$ (FAY 2007).

A ETU presente nas culturas, imediatamente após a aplicação de EBDC, é provavelmente aquela presente na formulação do fungicida. Pequenas quantidades de ETU também podem ser formadas durante a preparação da calda de aplicação e uma terceira fonte de formação de ETU pode ser devido à degradação dos EBDC depositados nas superfícies das culturas tratadas com estes fungicidas.

Encontram-se na literatura internacional alguns trabalhos de análise de resíduos de ETU em alimento in natura. Em várias amostras de maçã foram encontrados níveis de ETU que variaram de 0,018 a 0,044 ppm (NEWSOME 1972). Onley e col. (1977) reportaram que de 6 maçãs comerciais, somente uma apresentou resíduos de EBDC, contendo 0,01 ppm de ETU. Ripley e Cox (1978) detectaram ETU em níveis abaixo de 0,05 ppm em tomates e acima de 0,17 ppm em suco de tomates.

Dubey e col. 1997 monitoraram amostras do comércio para determinação de ditiocarbamatos e ETU e em 4 (20\%) das 20 amostras positivas para ditiocarbamatos ( 0,20 a $0,80 \mathrm{ppm}$ ) foram encontrados resíduos de ETU em níveis que variaram de $0,01$ a $0,37 \mathrm{ppm}$, sendo que 3 amostras eram de pêra ( 0,05 a $0,20 \mathrm{ppm})$.

Em estudo realizado na Itália, por Aprea e col., em 1997, foram encontrados $8,8 \mu \mathrm{g}$ de ETU/Litro de vinho. Para frutas e vegetais a concentração de ETU estava abaixo do limite de detecção $(3-20 \mu \mathrm{g} / \mathrm{kg})$, com exceção de uma amostra composta por massa com brócolis, mistura de vegetais, pêra e água (almoço), que apresentou $3 \mu \mathrm{g} / \mathrm{kg}$.

Blasco e col. (2004) estudaram resíduos de fungicidas em 10 amostras de vegetais adquiridas em diferentes supermercados de Valência, Espanha, sendo que ETU foi detectada em duas amostras de arroz em níveis de até $0,32 \mathrm{mg} / \mathrm{kg}$ e em uma de tomate $(0,36 \mathrm{mg} / \mathrm{kg})$.

Araujo, em 1998, detectou resíduos de ETU em 25 (78\%) das 32 amostras de tomate de mesa e em 15 (55\%) das 27 amostras de tomate industrial, sendo que 3 (11\%) amostras de tomate industrial e apenas $1(3 \%)$ apresentaram resultados acima do limite de quantificação do método de $0,025 \mathrm{mg} / \mathrm{kg}$ 
De uma maneira geral, os resutados desse estudo estão bem abaixo dos encontrados em estudos anteriores e, também, do esperado pelos dados de estudos de resíduos de ditiocarbamatos da literatura.

Os processos de degradação de EBDC à ETU são influenciados pelas condições climáticas (temperaturas elevadas e alta umidade) (FAY e col. 2007). A conversão de EBDC à ETU pode ocorrer também pela adição de compostos redutores como cisteína, glutationa ou ácido ascórbico (Hajslová e col. 1986). O DIDT é um produto de decomposição espontânea dos EBDC e a presença de compostos de redução favorece este processo. E, portanto, supõe-se que variações nas quantidades de EBDC e ETU devem ser esperadas em produtos com resíduos de EBDC e com quantidades variadas de compostos de redução, e dependendo das condições de temperatura, $\mathrm{pH}$ e umidade, mais ou menos rápida é a transformação de EBDC para ETU e, conseqüentemente, mais ou menos rápida pode ser a decomposição de ETU à EU.

As frutas estudadas que contêm maiores quantidades de Vitamina $\mathrm{C}$ em ordem decrescente são: morango (70 mg/100g), mamão (46 mg/100g) e maçã (6mg/100g), conforme pode ser observado na Tabela 15. Maiores quantidades de antioxidantes desfavorem a conversão de ETU à EU, maior produto de degradação, a qual é facilmente oxidada.

Menor quantidade de composto de redução pode não favorecer a redução quantitativa de EBDC na amostra e, sendo assim, os resíduos permaneceriam inalterados por mais tempo. Porém, esses podem, ainda, serem metabolizados no organismo.

A exposição da população à ETU pelo consumo de alimentos apresenta vários componentes: os resíduos de ETU já formados antes de serem ingeridos, nas condições de industrialização ou no campo; os remanescentes da aplicação de EBDC nas culturas; os formados pelo processamento ou pelo preparo e cozimento de alimentos com resíduos de EBDC e/ou os metabolizados no organismo, após ingestão. Sendo assim, na avaliação de risco à saúde relacionado à ETU, devem ser considerados os resíduos de EBDC e de ETU nos alimentos.

A estimativa da ingestão de resíduos de ETU, considerando os dados de consumo fornecido pelo IBGE (2005) e os maiores valores encontrados, nesta 
pesquisa, em maçã, mamão, morango, representam 0,02, 0,03 e <0,01\% da IDA, estabelecida pelo Codex Alimentarius (Tabela 22), respectivamente para cada uma das matrizes estudadas.

Considerando a dose oral crônica de efeito não carcinogênico, incluindo subgrupos mais sensíveis da população, estabelecida pelo EPA, a ingestão estimada de resíduos de ETU foi de 0,42, 0,64 e 0,01\%, respectivamente, para maçã, mamão e morango (Tabela 22).

Tabela 22 - Estimativa da ingestão de ETU pelo consumo de maçã, mamão e morango, em \% da IDA ( $2 \mu \mathrm{g} / \mathrm{kg} \mathrm{pc} / \mathrm{dia})$, e da dose oral crônica de efeito não carcinogênico - Drf $(0,08 \mu \mathrm{g} / \mathrm{kg}$ pc /dia)

\begin{tabular}{|c|c|c|c|c|c|c|}
\hline Fruta & $\begin{array}{c}\text { ETU } \\
\text { valor } \\
\text { máximo } \\
(\mu \mathrm{g} / \mathrm{kg})\end{array}$ & $\begin{array}{c}\text { Consumoa } \\
\text { (g/pessoa/dia) }\end{array}$ & $\begin{array}{c}\text { Estimativa } \\
\text { Ingestão de } \\
\text { ETU }^{\mathbf{b}} \\
(\mu \mathrm{g} / \text { pessoa } \\
\text { /dia) }\end{array}$ & \begin{tabular}{|c|} 
Estimativa \\
Ingestão de \\
ETU $^{\mathrm{b}}$ \\
$(\mu \mathrm{g} / \mathrm{kg} \mathrm{pc}$ \\
/dia $)$
\end{tabular} & $\begin{array}{c}\text { Risco } \\
\text { \% IDA } \\
\% \text { Drf } \\
\text { (Adulto) }\end{array}$ & $\begin{array}{c}\text { Risco } \\
\% \text { IDA }^{\mathbf{c}} \\
\% \text { Drf }^{d} \\
\text { (Criança) }\end{array}$ \\
\hline Maçã & 3,7 & 5,504 & 0,0204 & 0,00034 & $\begin{array}{l}\mathbf{0 , 0 2} \\
0,42\end{array}$ & $\begin{array}{l}\mathbf{0 , 0 8} \\
1,68\end{array}$ \\
\hline Mamão & 5,3 & 5,827 & 0,0309 & 0,00051 & $\begin{array}{l}0,03 \\
0,64\end{array}$ & $\begin{array}{l}0,12 \\
2,56\end{array}$ \\
\hline Morango & 1,4 & 0,367 & 0,0005 & 0,000008 & $\begin{array}{c}\mathbf{0 , 0 0 0 4} \\
0,01\end{array}$ & $\begin{array}{c}\mathbf{0 , 0 0 1 6} \\
0,04\end{array}$ \\
\hline Total & & & & & $\begin{array}{l}0,05 \\
1,07\end{array}$ & $\begin{array}{l}0,20 \\
4,28\end{array}$ \\
\hline
\end{tabular}

Fonte: (FAO/WHO 1994); (EPA 2007a); IBGE (2005).

a = baseado na média de consumo alimentar per capita anual para a cidade de São Paulo, de acordo com dados do IBGE (2005); $b=$ supondo que todas as frutas estudadas apresentassem os maiores níveis encontrados; c=Ingestão Diária Aceitável (IDA) para população em geral, de acordo com Codex Alimentarius (FAO/WHO 1994); d = Drf - Dose oral crônica de efeito não carcinogênico, incluindo subgrupos sensíveis da população (EPA 2007a) como crianças, gestantes. 
As somas das estimativas para as frutas estudadas representaram $0,05 \%$ da IDA de ETU (Codex Alimentarius) e 1,07 \% da dose oral de referência estabelecida pelo EPA, conforme pode ser observado na Tabela 22.

Como não existem dados de monitoramento de resíduos para todas as culturas nas quais é permitido o uso de EBDC, foi feita uma estimativa de ingestão pelo cálculo da Ingestão Diária Máxima Teórica nacional, considerando o consumo médio per capita de cada alimento para a cidade de São Paulo e o $\mathrm{LMR}_{\mathrm{j}}$ como sendo o nível de resíduo em cada alimento, em pesquisa anterior realizada por LEMES e col. (2005).

A TMDI para EBDC representou 47\% da IDA. Como não são estabelecidos LMR para ETU na legislação brasileira, foi estimada a TMDI para ETU, pelos dados obtidos da conversão de EBDC à ETU, baseada em estudos realizados com animais de experimentação. A TMDI estimada para ETU representou 108\% da IDA. Se a população estivesse ingerindo todos os alimentos com níveis iguais aos LMR permitidos poderia aumentar o risco de efeito adverso à saúde pela ingestão de ETU, uma vez que o valor da IDMT de EBDC ultrapassou a IDA (LEMES e col. 2005). Porém, a TMDI é uma superestimativa porque supõe que todos os alimentos para os quais é permitido o uso do agrotóxico possuem resíduos iguais ao LMR estabelecidos e não se baseia em dados reais de monitoramento. Neste caso, são necessárias estimativas mais precisas para avaliar o risco à saúde pela ingestão de resíduos de ETU pelo consumo de alimentos.

No Brasil, os LMR dos ditiocarbamatos são estabelecidos para $\mathrm{CS}_{2}(\mathrm{mg} / \mathrm{kg})$ em função do uso dos ingredientes ativos para cada cultura. É autorizado o uso de mancozebe e metiram para maçã, de mancozebe para mamão e de metam sódico para morango. Os LMR para maçã, mamão e morango são respectivamente de 2,0; 3,0 e 0,2 mg/kg, conforme Tabela 4 (MINISTÉRIO DA SAÚDE 2003).

Vários autores do Brasil e do mundo, têm pesquisado resíduos de ditiocarbamatos como $\mathrm{CS}_{2}$ e têm encontrado resíduos em amostras de maçã, mamão e morango, sendo alguns deles descritos a seguir.

Segundo dados obtidos por um laboratório na Holanda, foram encontrados ditiocarbamatos acima do LMR em 5 (100\%) amostras de mamão Papaya carica L. originário do Brasil, em níveis que variaram de $\mathbf{0 , 3}$ a 0,6 mg/kg (DE KOK 1999). 
Caldas e col (2004) analisaram resíduos de ditiocarbamatos (em $\mathrm{CS}_{2}$ ) em amostras de alimentos coletadas em supermercados do Distrito Federal entre 1999 e 2000 e encontraram níveis de até $1,9 \mathrm{mg} / \mathrm{kg}$ em 37(95\%) das amostras de maçã; 1,9 $\mathrm{mg} / \mathrm{kg}$ em 35 (63\%) das amostras de polpa de mamão+semente e de até $3,8 \mathrm{mg} / \mathrm{kg}$ em 47 (55\%) das amostras de morango.

Resíduos de ditiocarbamatos foram encontrados em 66 (44\%) das amostras de maçã de um estudo realizado na Eslovênia (2001-2004), porém abaixo do LMR (CESNIK 2006).

De 196 amostras de morango analisadas na Holanda, em 1998, 179 (91 \%) apresentaram resíduos de ditiocarbamatos em níveis que variaram de 0,1 a 0,6 $\mathrm{mg} / \mathrm{kg}$, porém, todas dentro do LMR permitido, que é de $3 \mathrm{mg} / \mathrm{kg}$ (DE KOK 1999).

Oliveira e Toledo (1995) não detectaram níveis de mancozebe no limite de quantificação do método $(\mathbf{0 , 5} \mathbf{m g} / \mathbf{k g})$ em amostras de morango coletadas na CEASA de Campinas.

Em Belo Horizonte-MG, resíduos de ditiocarbamatos foram determinados em 87 amostras de frutas e foi constatata a presença de ditiocarbamatos em $\mathrm{CS}_{2}$ em $37 \%$ das amostras de morango (37\%) (PEREIRA 1988).

De uma maneira geral, os níveis de ditiocarbamatos em morango, no Brasil, têm sido menores do que em mamão e maçã.

No Programa Nacional de Análise de Resíduos de Agrotóxicos em Alimentos - PARA (período de 2001-2002) foram encontrados resíduos de ditiocarbamatos, em $68(69 \%)$ das 99 amostras de maçã, em níveis que variaram de 0,04 a 2,10 mg/kg; em 58 (40\%) das 144 amostras de mamão, de 0,10 a 2,14 mg/kg); em 85 (60\%) das 141 amostras de morango, de 0,10 a $1,03 \mathrm{mg} / \mathrm{kg}$; em 1 (1\%) das 92 amostras de banana $(0,01)$ e em $1(1 \%)$ das 141 amostras de laranja. Foram também encontrados resíduos de ditiocarbamatos em 100 (52\%) das 189 amostras de tomate, em níveis que variaram de 0,07 a 1,50 mg/kg; em 57 (35\%) das 162 amostras de alface, em níveis que variaram de 0,10 a 3,50 mg/kg; e em nenhuma das 176 amostras de batata e em nenhuma das 134 amostras de cenoura (ANVISA 2003). Em 2003 foram encontrados resíduos de ditiocarbamatos em 35 (32\%) das 109 amostras de maçã, em níveis que variaram de 0,08 a 1,48 mg/kg; em 30 (21\%) das 143 amostras de mamão, de 0,09 a 1,2 mg/kg; em 25 (17\%) das 143 amostras de 
morango, de 0,09 a 1,10 mg/kg. Em 2004 foram encontrados resíduos de ditiocarbamatos, em 135 (84\%) das 161 amostras de maçã, em níveis que variaram de 0,2 a 2,0 mg/kg; em $124(77,5 \%)$ das 160 amostras de mamão, de 0,2 a 3,97 $\mathrm{mg} / \mathrm{kg}$ ) e em $9(6 \%)$ das 151 amostras de morango, de 0,1 a 1,4 mg/kg (ANVISA 2005).

Os ditiocarbamatos têm sido encontrados também em outras frutas destinadas à exportação. Em monitoramento de resíduos de agrotóxicos realizada por Araújo e col. (2001), os ditiocarbamatos $\left(\mathrm{CS}_{2}\right)$ foram encontrados em $5 \%$ das amostras de manga e em $27 \%$ das de uva, em níveis de 0,06 a $0,07 \mathrm{mg} / \mathrm{kg}$ e de 0,06 a $0,90 \mathrm{mg} / \mathrm{kg}$, respectivamente. Os valores detectados nas mangas, quando comparados com a legislação brasileira e o Codex Alimentarius (Tabela 4), estão dentro do LMR, porém em desacordo com LMR estabelecido pela União Européia de 0,05 mg/kg. Entretanto, para as uvas os valores encontrados estão abaixo dos LMR estabelecidos pelos maiores países importadores que variam entre 2 e $5 \mathrm{mg} / \mathrm{kg}$ de $\left(\mathrm{CS}_{2}\right)$, e também do LMR estabelecido no Brasil de 3,0 $\mathrm{mg} / \mathrm{kg}$ de $\left(\mathrm{CS}_{2}\right)$.

A IDA para a classe dos EBDC (mancozebe, manebe, metiram e zinebe), para cada princípio ou em qualquer combinação, estabelecida pelo JMPR, grupo assessor do Codex Alimentarius e, também, pela legislação brasileira, é de $0,03 \mathrm{mg} / \mathrm{kg} / \mathrm{dia}$ de $\mathrm{CS}_{2}$ (MINISTÉRIO DA SAÚDE 2003), e a de ETU é de 0,002 mg/kg/dia (FAO/WHO 1994). Como apenas a partir de EBDC pode-se formar a ETU, limites totais de ditiocarbamatos, em $\mathrm{CS}_{2}$ não permitem avaliação em relação aos níveis de ETU, pois o uso de qualquer ditiocarbamato gera $\mathrm{CS}_{2}$ pelo método analítico. Porém, quase a totalidade dos princípios ativos, com autorização de uso em frutas, é da classe dos EBDC, o que permite traçar um indicativo dos resultados encontrados nos estudos de monitoramento realizados nos últimos anos no Brasil.

$\mathrm{Na}$ Tabela 23 encontra-se a avaliação de risco de exposição a EBDC pelos resultados obtidos nos alimentos (maçã, mamão, morango, alface, banana, cenoura, laranja, tomate), analisados pelo PARA (2001-2004) (ANVISA 2005).

A Tabela 24 apresenta a estimativa do risco de exposição à ETU (calculada) pelos resultados obtidos nos alimentos (maçã, mamão, morango, alface, banana, cenoura, laranja, tomate), analisados no período de 2001 a 2004 no PARA (ANVISA 2005). 
Tabela 23 - Avaliação de risco de exposição a EBDC pelos resultados obtidos nos alimentos analisados pelo PARA (20012004)

\begin{tabular}{|c|c|c|c|c|c|c|}
\hline Fruta & $\begin{array}{c}\text { Consumo }^{\mathrm{a}} \\
\text { (g/pessoa/dia) }\end{array}$ & $\begin{array}{c}\text { Ditiocarbamato } \\
\text { maior valor } \\
\text { PARA(2001-2004) } \\
(\mathrm{mg} / \mathrm{kg})\end{array}$ & $\begin{array}{c}\text { Estimativa }^{\mathbf{b}} \\
\text { Ingestão de } \\
\text { Ditiocarbamato } \\
\text { (mg/pessoa/dia) }\end{array}$ & $\begin{array}{c}\text { Estimativa }^{c} \\
\text { Ingestão de } \\
\text { EBDC }\left(C_{2}\right) \\
(\mu \mathrm{g} / \mathrm{kgpc} / \mathrm{dia})\end{array}$ & $\begin{array}{c}\text { Risco } \\
\% \\
\text { IDA }^{d} \\
\text { Aduto } \\
\text { (60kg) } \\
\end{array}$ & $\begin{array}{c}\text { Risco } \\
\% \\
\text { IDA }^{d} \\
\text { Criança } \\
(15 \mathrm{~kg}) \\
\end{array}$ \\
\hline Maçã & 5,5 & 2,10 & 0,01155 & 0,19 & 0,64 & 2,56 \\
\hline Mamão & 5,9 & 3,97 & 0,02342 & 0,20 & 0,68 & 2,72 \\
\hline Morango & 0,4 & 1,4 & 0,00056 & 0,01 & 0,03 & 0,12 \\
\hline Sulb total & & & & 0,40 & 1,35 & 5,40 \\
\hline Alface & 2,3 & 1,72 & 0,00396 & 0,06 & 0,22 & $\mathbf{0 , 8 8}$ \\
\hline Banana & 20,6 & 1,95 & 0,04017 & 0,67 & 2,23 & 8,92 \\
\hline Cenoura & 5,4 & 2,16 & 0,01166 & 0,19 & 0,65 & 2,60 \\
\hline Laranja & 16,0 & $\mathbf{0 , 8 2}$ & 0,01312 & 0,22 & $\mathbf{0 , 7 3}$ & 2,92 \\
\hline Tomate & 16,9 & 2,17 & 0,03667 & 0,61 & 2,04 & 8,16 \\
\hline Total & & & & 2,16 & 7,22 & 28,88 \\
\hline
\end{tabular}

$\mathrm{a}$ = baseado na média de consumo alimentar per capita anual para a cidade de São Paulo, de acordo com dados do IBGE (2005); $\mathrm{b}=$ supondo que todas as frutas consumidas apresentassem os maiores níveis encontrados no período de 2001 a 2004 no PARA (ANVISA 2005); c = supondo que os resultados de ditiocarbamatos (CS2) são provenientes do uso de EBDC; d= IDA de 30 g g/kgpc/dia (MINISTÉRIO DA SAÚDE 2003). 
Tabela 24 - Estimativa do risco de exposição à ETU (calculada) pelos resultados obtidos nos alimentos analisados no período de 2001 a 2004 no PARA (ANVISA 2005)

\begin{tabular}{|c|c|c|c|c|c|c|}
\hline Fruta & $\begin{array}{c}\text { Consumoa } \\
\text { (g/pessoa/dia) }\end{array}$ & $\begin{array}{c}\text { Ditiocarbamato } \\
\text { (> valor) PARA } \\
(2001-2004) \\
(\mathrm{mg} / \mathrm{kg})\end{array}$ & $\begin{array}{c}\text { Estimativa } \\
\text { Ingestão de } \\
\text { EBDC }^{\text {b,c }} \\
\text { (mg/pessoa/dia) }\end{array}$ & $\begin{array}{c}\text { Estimativa da } \\
\text { ingestão de ETU }{ }^{d} \\
(\mu \mathrm{g} / \mathrm{kgpc} \text { dia })\end{array}$ & $\begin{array}{c}\text { Risco } \\
(\%) \text { IDA }^{\mathrm{e}} \\
\text { Adulto } \\
(60 \mathrm{~kg})\end{array}$ & $\begin{array}{c}\text { Risco } \\
(\%) \mathrm{IDA}^{\mathrm{e}} \\
\text { Criança } \\
(15 \mathrm{~kg})\end{array}$ \\
\hline Maçã & 5,5 & 2,10 & 0,01155 & 0,0167 & 0,83 & 3,32 \\
\hline Mamão & 5,9 & 3,97 & 0,02342 & 0,0177 & 0,89 & 3,56 \\
\hline Morango & 0,4 & 1,4 & 0,00056 & 0,0005 & 0,02 & 0,08 \\
\hline Sulb total & & & & 0,0349 & 1,74 & 6,96 \\
\hline Alface & 2,3 & 1,72 & 0,00396 & 0,0034 & $\mathbf{0 , 1 7}$ & 0,68 \\
\hline Banana & 20,6 & 1,95 & 0,04017 & 0,0582 & 2,91 & 11,64 \\
\hline Cenoura & 5,4 & 2,16 & 0,01166 & 0,0169 & $\mathbf{0 , 8 5}$ & 3,40 \\
\hline Laranja & 16,0 & $\mathbf{0 , 8 2}$ & 0,01312 & 0,0190 & 0,95 & 3,80 \\
\hline Tomate & 16,9 & 2,17 & 0,03667 & $\mathbf{0 , 0 5 3 2}$ & 2,66 & 10,64 \\
\hline Total & & & & 0,1857 & 9,28 & 37,12 \\
\hline
\end{tabular}

$\mathrm{a}=$ baseado na média de consumo alimentar per capita anual para a cidade de São Paulo, de acordo com dados do IBGE (2005); $\mathrm{b}=$ supondo que todas as frutas consumidas apresentassem os maiores níveis encontrados; $\mathrm{c}=$ supondo que os resultados de ditiocarbamatos $\left(\mathrm{CS}_{2}\right)$ são provenientes do uso de

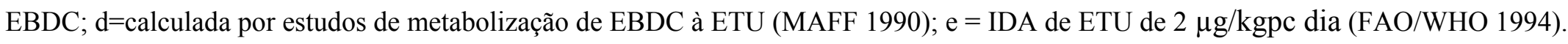


A Figura 45 ilustra as estimativas de risco de exposição à ETU e a EBDC em $\%$ IDA, considerando os valores totais para as frutas estudadas, obtidos nas Tabelas 22 (ETU estudo), 23 (EBDC pelos resultados em alimentos analisados pelo PARA no período de 2001-2004 e 24 (risco de exposição à ETU, calculado pela conversão de EBDC, pelos resultados obtidos nos alimentos analisados pelo PARA (2001 2004).

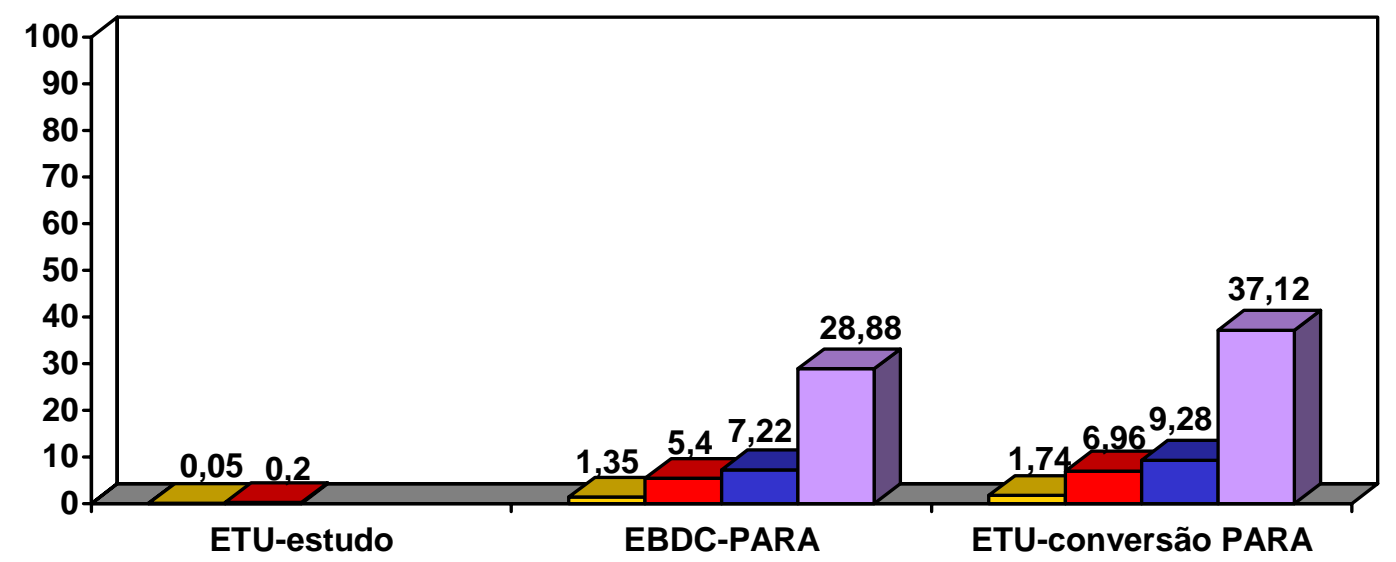

\section{$\square$ Frutas estudadas (população geral) $\quad \square$ Frutas estudadas (crianças) \\ $\square$ Alimentos PARA (população geral) $\quad \square$ Alimentos PARA (crianças)}

Figura 45 - Estimativas de risco de exposição à ETU e a EBDC em \% IDA, obtidas pelo resultado deste estudo e pelos obtidos nos alimentos monitorados pelo PARA

Apesar da melhora, nos últimos anos, das informações sobre resíduos de agrotóxicos nos alimentos, por meio de programas de monitoramento, ainda faltam dados de consumo de subgrupos de risco importantes, como os vegetarianos, bebês e as mulheres grávidas.

Deve-se considerar que crianças consomem frutas in natura e legumes cozidos e industrializados desde os primeiros meses de vida e, por apresentarem menor peso corpóreo, o risco de ingestão de ETU ou de outro contaminante, pelo consumo de alimento, é maior do que no adulto (LEMES 2003). Além disso, bebês e crianças possuem capacidade metabólica reduzida na eliminação de produtos tóxicos e são mais susceptíveis a substâncias que atuam no sistema nervoso central 
(PEREIRA 2005), sendo importante o conhecimento de dados de consumo de alimentos por estas faixas etárias.

No estudo realizado por Caldas e col., em 2006, foi estimado o risco de ingestão de resíduos EBDC, em \% IDA, para a população geral e crianças acima de 6 anos, considerando que $100 \%$ dos resíduos de ditiocarbamatos $\left(\mathrm{CS}_{2}\right)$ como sendo originários do uso de EBDC, e considerando como 30\% dessses resíduos do uso de propinebe. Neste estudo, maçã e tomate foram os produtos que apresentaram concentrações médias de ditiocarbamatos mais elevadas, sendo que o tomate contribuiu com $24,6 \%$ do total da ingestão diária, seguido pelo arroz $(20,1 \%)$, maçã $(19,2 \%)$, alface $(8,8 \%)$ e feijão $(8 \%)$. O morango foi o que menos contribuiu $(0,3 \%$ da IDA). Pela Tabela 23, considerando 8 produtos analisados (maçã, tomate, mamão, alface, morango, banana, laranja, cenoura), a estimativa da ingestão de resíduos de EBDC pelo consumo dos alimentos monitorados pelo PARA, foi de $7,2 \%$ para a população em geral e de 28,9 \% para crianças e no estudo realizado por Caldas e col., 2006, considerando o pior cenário entre as regiões brasileiras, em onze produtos (maçã, tomate, mamão, alface, morango, banana, laranja, cenoura, batata, feijão, arroz), com dados de dois monitoramentos (PARA e Distrito Federal), foi de 11,9\% para a população geral e $31,1 \%$ para crianças. Porém, nestes estudos foram comtemplados apenas alguns vegetais, sendo que mais 28 possuem registros autorizados para o uso de ditiocarbamatos (Tabelas 4,5 e 6).

$\mathrm{O}$ risco de exposição à ETU, calculado pela conversão de EBDC à ETU, considerando que todos os resíduos de ditiocarbamatos encontrados no PARA (20012004) são originários do uso de EBDC, representa 9,3\% da IDA para a população geral e $37,1 \%$ para crianças (Tabela 24 e Figura 45 )

O valor limite de tolerância para resíduos de ETU de $50 \mu \mathrm{g} / \mathrm{kg}$, estabelecido pela Comunidade Européia é alto, frente a uma IDA de $2 \mu \mathrm{g} / \mathrm{kg}$ p.c/dia (FAO/WHO 1994) e, considerando os estudos de ingestão realizados, os dados de monitoramento e que no Brasil os EBDC são muito utilizados e têm autorização de uso para uma grande variedade de vegetais, propõe-se a avaliação deste valor para estabelecimento de um limite de resíduos de ETU nos alimentos mais compatível com a IDA estabelecida. 
A maior preocupação deve ser considerada com alimentos consumidos cozidos e industrializados, pois os processos de preparo e de manufatura podem favorecer a decomposição dos EBDC à ETU, ocasionando o aumento dos níveis de ETU nestes produtos. Bolzoni e col. (1993) analisaram 100 amostras de produtos industrializados de tomate e encontraram etilenotiouréia em apenas 7 amostras, em níveis que variaram de 3 a $26 \mu \mathrm{g} / \mathrm{kg}$. Pesquisadores encontraram resíduos de ETU em amostras de alimentos infantis, sendo em 38 (12\%) das 310 amostras à base de frutas ou suco de frutas; em 11 (6\%) das 167 amostras originárias de vegetais, em 6 $(9 \%)$ de 65 amostras de cereais e em 9 (13\%) das 70 amostras de sobremesas (YESS e col. 1993 citado por RICHARDSON 1998 p. 21). Casanova e Guichon (1988) encontraram resíduos de ETU em 22\% das amostras de cerveja e em 7\% das amostras de vinho em níveis de 0,01 a $0,1 \mathrm{mg} / \mathrm{kg}$.

Porém, estudos demonstram que pessoas estão expostas a EBDC e/ou à ETU, pois a ETU têm sido detectada em urina de pessoas da população em geral, expostas ocupacionalmente ou ao meio ambiente, conforme pode ser observado nos estudos citados a seguir.

Em estudo realizado na Itália por Aprea e col. (1996) em urina foram encontrados resíduos de ETU acima do limite de tolerância estabelecido de 1,0 $\mu \mathrm{g} / \mathrm{L}$ em $24 \%$ da população de referência (167 pessoas não expostas) e em $37 \%$ da população exposta (97 pessoas de Rovescala, onde os EBDC são pulverizados por via aérea - helicóptero). Os valores de ETU encontrados na urina variaram de 0,8 a $8,3 \mu \mathrm{g} / \mathrm{L}$, para a população de referência, e de 0,9 a $61,4 \mu \mathrm{g} / \mathrm{L}$, para a população exposta, sendo que fumantes e consumidores de vinho apresentaram variação estatisticamente significante dos níveis de ETU.

Em amostras de uva e vinho também têm sido detectados resíduos de ETU, inclusive em urina de consumidores de vinho. Aprea e col. (1997) monitoraram a excreção urinária de ETU durante oito dias em voluntários, do sexo masculino e não fumantes, submetidos a uma dieta com alimentos previamente analisados para determinação dos teores de ETU e de ditiocarbamatos (como $\mathrm{CS}_{2}$ ). A concentração de ETU no vinho, foi de $8,8 \mu \mathrm{g} / \mathrm{L}$ e nos alimentos ingeridos pelos voluntários foi inferior ao limite de detecção do método utilizado. Os níveis de $\mathrm{CS}_{2}$ em amostras de consumo diário alimentar variaram de 0,03 a $0,17 \mathrm{mg} / \mathrm{kg}$. Uma média de 48,3\% de 
ETU ingerida pelo consumo de vinho foi excretada inalterada pela urina. A correlação entre a excreção urinária de ETU em 24 horas e a ingestão diária de ETU foi de 0,768 , e com os níveis de $\mathrm{CS}_{2}$ encontrados nos alimentos a correlação foi de 0,414 .

Como o consumo médio diário de água é de $2 \mathrm{~L}$ por pessoa, deve-se considerar também esses dados, quando disponíveis. A EPA tem considerado o risco carcinogênico de $1 \mu \mathrm{g} / \mathrm{L}$ para ETU em água de consumo, sendo que o risco agregado estimado de ETU não deve exceder este nível. (EPA 2007b).

Comparando os critérios brasileiros de avaliação de risco de resíduos de agrotóxicos nos alimentos com os critérios utilizados nos Estados Unidos, no Reino Unido e pelo Codex Alimentarius, nota-se a necessidade de um grande volume de dados e informações que ainda são incipientes no Brasil.

Além de que, levando em consideração que o risco à saúde humana se deve a exposição não apenas pela dieta alimentar, mas também pelo consumo de água e originária do ambiente, portanto, o risco real de exposição à ETU é a somatória de todas essas fontes.

A falta de conhecimento, no Brasil, de dados mais completos de resíduos de agrotóxicos nos alimentos, na água e no meio ambiente, e sobre o consumo dos alimentos, não permite estimar o risco à saúde dos consumidores de alimentos em relação aos resíduos de agrotóxicos de uma maneira mais condizente com a realidade.

Estimativa mais realista só poderá ser feita quando essas informações estiverem disponíveis.

Para prevenção de risco de exposição a EBDC e à ETU, bem como a outros princípios ativos, destaca-se que é extremamente importante o monitoramento dos alimentos e da água, para conhecimento dos níveis de contaminação por agrotóxicos nos produtos destinados ao consumo e para promover ações que minimizem a exposição em benefício da Saúde Pública. 


\section{CONCLUSÕES}

Este trabalho apresenta a determinação dos níveis de resíduos de ETU em maçã, mamão e morango, e representa uma contribuição indicativa importante para estimar o risco à saúde da população consumidora destas frutas, pela aplicação de uma metodologia desenvolvida e validada para os seguintes parâmetros: seletividade, linearidade, exatidão, precisão, limite de quantificação, limite de detecção, robustez.

O método de determinação de resíduos da ETU, por cromatografia a líquido acoplada à espectrometria de massas (LC/MS/MS), desenvolvido e adaptado para matrizes estudadas, mostrou-se adequado para análise de ETU nos níveis de até 2,0 $\mu \mathrm{g} / \mathrm{kg}$ para maçã e morango e de até $10,0 \mu \mathrm{g} / \mathrm{kg}$ para mamão, com recuperações médias de 75 e $110 \%$ e coeficientes de variação de 6 a 17\%. Permitiu a realização desse estudo, contribuiu com a literatura e possibilita também a realização de novas pesquisas para avaliação de contaminação ambiental, uma vez que permite a quantificação no nível de $1,0 \mu \mathrm{g} / \mathrm{kg}$ e/ou que se trabalhe com menores quantidades de amostra, no caso dos alimentos, com menor tempo de análise e diminuição do uso de solventes tóxicos.

Foi verificada a presença de resíduos de ETU em 10 (33\%) das amostras de maçã, em níveis que variaram de 1,0 a 3,7 $\mu \mathrm{g} / \mathrm{kg}$ (ppb); em 20 (67\%) das amostras de mamão Carica Papaya L. com casca, de 1,0 a 5,3 $\mu \mathrm{g} / \mathrm{kg}$; em 2 (7\%) das amostras de morango, de 1,0 a 1,4 $\mu \mathrm{g} / \mathrm{kg}$. Estes valores estão abaixo do limite de $50 \mu \mathrm{g} / \mathrm{kg}$, estabelecido na União Européia.

A estimativa da ingestão de resíduos de ETU pela ingestão das frutas estudadas, considerando o consumo fornecido pelo IBGE e o maior nível encontrado nesta pesquisa, representam respectivamente 0,05 e $0,20 \%$ da IDA (estabelecida pelo Codex Alimentarius), para a população em geral e crianças. 
A estimativa da ingestão de resíduos de EBDC pelo consumo dos alimentos (maçã, tomate, mamão, alface, morango, banana, laranja, cenoura), monitorados pelo PARA no período de 2001 a 2004, considerando os maiores níveis encontrados e $100 \%$ dos resíduos de ditiocarbamatos $\left(\mathrm{CS}_{2}\right)$ como sendo originários do uso de EBDC, foi de 7,2\% para a população em geral e de $28,9 \%$ para crianças.

No Brasil, a carência de dados mais completos de resíduos de agrotóxicos nos alimentos, na água e no meio ambiente e também com relação ao consumo de alimentos, não permite de uma maneira mais condizente com a realidade, estimar o risco à saúde dos consumidores. Estimativa mais realista só poderá ser feita quando essas informações estiverem disponíveis. Portanto, destaca-se que é importante o conhecimento dos níveis de resíduos de EBDC e ETU em alimentos e em água para promover ações que minimizem a exposição, em benefício da Saúde Pública. 


\section{RECOMENDAÇÕES}

\section{- Pesquisas}

Esta pesquisa é uma contribuição importante para avaliação do risco à Saúde Pública de exposição à ETU. Porém, ainda há carência de muitos dados que pode ser sugerida:

Estudos de resíduos de ETU em outros produtos in natura que compõem a dieta do brasileiro para avaliar o potencial de risco à saúde da população consumidora;

Pesquisa de produtos de origem vegetal industrializados, pois o preparo de alimentos e os processos de fabricação podem favorecer a decomposição dos EBDC à ETU;

Avaliação de resíduos de EBDC e ETU em água de consumo e em outras amostras do meio ambiente (água, solo, organismos aquáticos, sedimento);

Identificação dos níveis de exposição ocupacional a EBDC e à ETU, analisando a urina de trabalhadores, principalmente dos aplicadores de agrotóxicos da classe dos ditiocarbamatos, incluindo os EBDC;

Pesquisa dos níveis de EBDC e de ETU na mesma matriz, para isso deve-se estudar e utilizar um método capaz de determinar, simultaneamente, os EBDC e a ETU; 


\section{- Sugestões de medidas para redução da contaminação por EBDC e/ou por ETU}

Estabelecer medidas para a minimização de resíduos de EBDC e/ou de ETU antes do processamento industrial e preparo dos alimentos, para evitar formação de maiores níveis de ETU no produto final. Os consumidores de frutas, verduras e outros vegetais, principalmente quando ingeridos in natura, devem lavá-los com água clorada antes do consumo;

Dar preferência a métodos alternativos de controle de pragas, quando possível;

Usar somente agrotóxicos de uso autorizado para a cultura, apenas quando necessário, dando preferência aos menos tóxicos, e utilizá-los de acordo com a Boa Prática Agrícola (BPA);

Não aplicar os EBDC na presença de ventos fortes ou nas horas quentes do dia, ou próximos a cursos d'água e em lugares com muito declive, por causa do possível arraste para rios e lagos e conseqüente contaminação dos recursos hídricos e dispersão aérea;

Descartar corretamente as embalagens, de acordo com a legislação vigente;

Participar de ações preventivas que levem em conta a saúde do consumidor, o meio ambiente e, principalmente, a de trabalhadores expostos;

E, principalmente, monitorar os resíduos de agrotóxicos nos alimentos in natura e industrializados para conhecimento e promoção de ações de prevenção à Saúde Pública. 


\section{REFERÊNCIAS BIBLIOGRÁFICAS}

Amaral JD dos, Simizu K, Moraes Barros SB de, Junqueira VBC. Efeitos da etilenotiouréia (ETU) e da elileno-uréia (EU) sobre os níveis de lipoperoxidação hepática em ratos. Rev Farm Bioquim Univ São Paulo 1985; 21(2):183-7, jul.-dez., 1985.

[ANDEF] Associação Nacional de Defesa Vegetal. Vendas 1988 a 1998 [online]. Disponível em <URL:http://www.andef.com.br/dentro/bmercado.htm> [2003a fev $12]$.

[ANDEF] Associação Nacional de Defesa Vegetal Boa Prática Agrícola. [online]. Disponível em <URL:http://www.andef.com.br/dentro/agri te6.htm $>$ [2003b fev 12].

Ankumah RO, Marshall WD. Persistence and fate of ethylene thiourea in tomato sauce and paste. J Agric Food Chem 1984, 32: 1194-8.

[ANVISA] Agência Nacional de Vigilância Sanitária. Programa de Análise de Resíduos de Agrotóxicos em Alimentos - PARA. Resultados analíticos de 2002. Brasília; 2003. Disponível em <URL:http://www.anvisa.gov.br/toxicologia/ residuos/resl_anual_2002an2.pdf> [2003 nov 15].

[ANVISA] Agência Nacional de Vigilância Sanitária. Programa de Análise de Resíduos de Agrotóxicos em Alimentos - PARA. Relatório do PARA de 20012004. Brasília; 2005. Disponível em <URL:http://www.anvisa.gov.br/ toxicologia/ index. htm $>$ [2005 mai 27].

[ANVISA] Agência Nacional de Vigilância Sanitária. Resolução da Diretoria Colegiada - RDC n ${ }^{\circ} 216$, de 15 de dezembro de 2006. Estabelece parâmetros mínimos para validação de método analítico para estudos de resíduos de agrotóxicos e afins em produtos de origem vegetal e em cogumelos in natura destinados ao 
consumo humano e/ou animal. Diário Oficial da União, 21 de agosto de 2006. Disponível em <URL:http://www.anvisa.gov.br> [2007 mar 16].

Aprea C, Betta A, Catenacci G, Lotti A, Minoia C, Passini V et al. Reference values of urinary ethylenethiourea in four regions of Italy (multicentric study). Sci Total Environ 1996; 192(1):83-93.

Aprea C, Betta A, Catenacci G, Colli A, Lotti A, Minoia C, Olivieri P, Passini ; Pavan I, Roggi C, Ruggeri R, Sciarra G, Turci R, Vannini P, Vitalone V. Urinary excretion of ethylenethiourea in five volunteers on a controlled diet (multicentric study). The Sicence of the Total Environment 1997, 203: 167-79.

Aprea C, Sciarra G, Sartorelli P, Mancini R, Luca V.D. Environmental and biological monitoring of exposure to mancozeb, ethylenethiourea, and dimethoate during industrial formulation. Journal of Toxicology and Environmental Health Part A 1998, 53 (4): 263-81, Feb.

Araújo ACP. Importância da análise de resíduos de praguicidas para ações de saúde pública: estudo da cultura do tomate no Estado de Pernambuco. São Paulo; 1998. [Tese de Doutorado - Faculdade de Saúde Pública da Universidade de São Paulo].

Araújo ACP, Nogueira DP e Augusto LGS. Impacto dos praguicidas na saúde: estudo da cultura do tomate. Revista de Saúde Pública, 2000, 34(3):309-13.

Araújo ACP,Telles DL, Lima, LLA, Rodrigues J, Lima TLA, Silva M. Monitorização de resíduos de praguicidas em frutas destinadas à exportação. Revista Brasileira de Toxicologia 2001; 14(2): 43-48. 
Barretto HHC, Inomata ONK, Lemes VRR, Kussumi TA, Scorsafava MA, Rocha SOB. Monitoramento de resíduos de pesticidas em alimentos comercializados no Estado de São Paulo em 1994. Pestic Rev Téc Cient 1996; 6:1-12.

Bolanos LOV, Verdés JAA, Diaz TC,IValiene MLG. Uso de plaguicidas em Cuba, su repercusión em el ambiente y la salud. Rev Cubana Aliment Nutr 1997; 11(2):111-116.

Bolzoni L, Sanino A, Bandini M. Determination of ethylenethiourea and propylenethiourea in tomato products and in fruit purees. In: Food Chemistry. England: Elsevier Science; 1993. p.299-302.

Brasil. Decreto $n^{\circ} 4074$, de 04 de janeiro de 2002. Regulamenta a Lei $n^{\circ} 7.802$, de 11 de julho de 1989, que dispõe sobre pesquisa, experimentação, produção, embalagem e rotulagem, transporte, armazenamento, comercialização, propaganda comercial, utilização, importação, exportação, destino final dos resíduos e embalagens, registro, classificação, controle, inspeção e fiscalização de agrotóxicos, seus componentes e afins, e dá outras providências. Diário Oficial da União, Brasília, 08 jan. 2002. p. 112. Disponível em <URL: http://www.anvisa.gov.br/legis/decretos/4074_02.htm> [2003 abr 25]

Caldas ED, Miranda MCC, Conceição MH, Souza LCKR. Dithiocarbamates residues in Brasilian food and the potential risk for consumers. Food and Chemical Toxicology. 2004; 42:1877-1883.

Caldas ED, Tressou J, Boon PE. Dietary exposure of Brazilian consumers to dithiocarbamate pesticides--a probabilistic approach. Food Chem Toxicol, 2006: 44 (9):1562-71, Sep. 
Calumpang SMF, Medina MJB, Roxas NP, Magallonas ED. Movement and degradation of mancozeb fungicide and its metabolites, ethylenethiourea in sitty clay loam soil. Int J Pestic Manag 1993; 39:161-6.

Camilo, A P. e Denardl, F. Efeito do carbaryl sobre o "russeting" da maçã (Malus domestica borkh), cultivares "gala", "fugi" e "golden delicious" Rev. Bras. Frutic., dez.2001,.23,(3):.580-583. Disponível em $<$ URL: $<$ http://www.scielo.php?script=sci_ abstract\&pid=S0100-29452001000300027\&In> [2005 jul 26].

Camoni I, Di Muccio A, Pontecorvo D, Citti P. Survey of ethylenethiourea (ETU) in ethylenebis(ditiocarbamate) (EBDC) fungicides. Ecoloxicol Environ Safety 1988; 16(2): 176-9.

Canossa E, Angiuli G, Garasto G, Buzzoni A, De Rosa E. Indicadori di dose in agricoltori esposti a mancozeb. Med Lav 1993; 84:42-50.

Casanova M, Guichon, R. Resíduos of EBDC fungicides and ETU in experimental and comercial beverages. J Environ Sci Helath [B] 1988.; 23 (2): 179-88.

Cesnik HB, Gregorcic A, Bolta SV, Kmecl V. Monitoring of pesticide residues in apples, lettuce and potato of the Slovene origin, 2001-04. Food Addit Contam, 2006: 23(2):164-73, Feb.

Conceição $\mathrm{MH}$. Resíduos de pesticidas em tomates: metodologia analítica e avaliação da exposição humana. Brasília; 2002. [Tese de Doutorado - Instituto de Química da Universidade de Brasília].

Cruiskshank PA, Jarrow HC. Ethylenethiourea degradation. J Agric Food Chem $1973 ; 21: 33-4$.

Dearfield KL. Ethylenethiourea (ETU): a review of the genetic toxicity studies. Mutat Res 1994; 317:111-32. 
Debbarh I, Rambelomanana S, Penouil F, Castaigne F, Poisot D, Moore N. Human neurotoxicity of ethylene-bis-dithiocarbamates (EBDC). Rev Neurol, 2002; 158 (12 Pt 1):1175-80, Dec.

Denardi $\mathrm{F}$, Bertom $\mathrm{O}$, Spengler MM. Resistência genética à podridão amarga em maçãs, determinada pela taxa de desenvolvimento da doença em frutos com e sem ferimentos. Rev Brás Frutic 2005; 25: 3. Disponivel em URL: $<$ http://www.scielo.br/scielo.php?script=sci_arttext\&pid=S0100.2945200300030003 $3 \& \operatorname{Ing}>$ [ 2005 jul 26].

De Kok A. Control of pesticide residues in food European model. In: Procedings of Workshop Control of Pesticide Residues in Food European Model; 1999 out 4-6; Araraquara, (BR). São Paulo: GARP; 1999.

Dias, MSC. Morango. Livre de agrotóxicos, a fruta é nova opção para produtores do Norte de Minas. Reportagem de Vanessa Fagundes Minas Faz Ciência; 2005: 22 jun-ago. Disponível em URL: <http://revista.fapemig.br/reportagens.php/id=228> [2005 jul 26].

Diserens H. Determination of ethylenethiourea in various foods. Lab News 1991; 62:69-80.

Dubey JK, Heberer T, Stan Hans-Jügen. Determinationa of ethylenethiourea in food commodities by a two-step derivatization method and gas chromatography with electron-capture and nitrogen-phosphorus detection. Journal of Chromatography A, 1997 (765): 31-8.

Elia MC, Arce G, Hurt SS, Neill PJ, Scribner HE. The genetic toxicology of ethylenethiourea: a case study concerning the evaluation of a chemical's genotoxic potential. Mut Res 1995; 341:141-9. 
[EMBRAPA] Empresa Brasileira de Pesquisa Ambiental. Sistema de Produção do Morango. Disponível em http://www.embrapa.br/sistemas/morango/index.php [2005a jul 28].

[EMBRAPA] Mattos MLT. Meio ambiente e segurança alimentar. Disponível em $<$ http:// www.cpact.embrapa.br/sistemas/morgano/index.php?cap=1>, Disponível em [2005b jul 28].

[EMBRAPA]. Conquista da Produção Integrada de Frutas no Brasil. Matéria do Informativo Meio Ambiente e Agricultura 2003: 43 nov/dez. Disponível em URL: $<$ http://www.cnpma.embrapa.br/informativo/mostra_informativo.php3?id=203> [2005c jul 29].

[EPA] Environmental Protection Agency. Pesticides in Groundwater Database. Washington;1992, 5-35.

[EPA] Environmental Protection Agency. Office of Prevention, Pesticide and Toxic Substances. Residue chemistry test guidelines. Washington; 1996.

[EPA] Environmental Protection Agency. Office of Pesticide Programs. The determination of whether dithiocarbamate pesticides share a common mechanism of toxicity. Washington; 2001.

[EPA] Environmental Protection Agency. IRIS - Integrated Risk Information System. Disponível em <URL:http:/www.epa.gov/IRIS/subst/0239.htm> [2007a jan $11]$.

[EPA] Environmental Protection Agency. Risk Assessment and Statutory Findings. In: Mancozeb; Pesticide Tolerances for Emergency exemptions. Disponível em <URL:http://www.epa.gov/EPA-PEST/1998/October/Day-09/p27268.htm> [2007b jan 11]. 
European Comission. Quality control procedures for pesticide residues analysis. In: Guidelines for residues monitoring in the European Union. $2^{\text {nd }}$ edition. 2000a. p.1-30.

European Commision. Directorate General health and Consumer Protection. Guidance document on residual analytical methods: SANCO/825/00 rev. 6. $2000 \mathrm{~b}$.

European Commission. Monitoring of pesticide residues in products of plant origin in the European Union, Norway, Iceland and Liechtenstein. 2004. Disponível em $<$ http://europa.eu.int/comm/food/fs/inspections/fnaoi/reports/annual_ eu/monrep_2002_sum_en.pdf $>$ [2004c out 21].

[FAO/WHO] Food and Agriculture Organization of the United Nations/World Health Organization. Food Standards Programme Codex Alimentarius Commission. Good laboratory practice on pesticide residue in food. Rome; 1993. Suppl 1. v. 2. Section 4.2, 164 .

[FAO/WHO] Food and Agriculture Organization of the United Nations/World Health Organization. Food Standards Programme Codex Alimentarius Commission. Pesticide residues in food. Rome; 1994. v.2.

[FAO/WHO] Food and Agriculture Organization of the United Nations/World Health Organization. Food Standards Programme Codex Alimentarius Commission. Pesticide residues in food: maximum residue limits. Rome 2007. Disponível em URL:http://www.codexalimentarius.net $/ \mathrm{mrls} /$ servlet $/$ PesticideServlet?Pesticide $=\% 2 \mathrm{~F}$ pest_q_e.htm [2007 mai 05].

Freitas EAV, Coutinho JAG, Santos JA, Lins LCG, Cavalcanti MSD, Ferry RV. Uso de agrotóxicos no município de Pati do Alferes: um estudo de caso. Cad Geoc 1994; (10):23-31. 
Fay EF, Gorni R, Abakerli RB, Silva CMMS. Remoção de resíduos de ditiocarbamatos e de etilenotioureia. Disponível em URL: http://www.cpatsa.embrapa.br/sbpif6/resumos/Fay_remoção.doc. [2007 jan 19]

[FDA]. Food and Drug Administration Pesticide. Program Residue Monitoring, 2002. Disponível em URL: < $<$ http://www.cfsan.fda.gov/ acrobat/pes02rep.pdf $>$. [2004 out 10].

Frakes RA. Drinking water guideline for ethylene thiourea, a metabolite of ethylene bisdithiocarbamate fungicides. Regul Toxicol Pharmacol. 1988; 8 (2): 207-18.

Furlani PR e Fernandes Jr F. Cultivo hidropônico de plantas. Campinas, Instituto Agronômico, 1999, 52p (Boletim Técnico, 180).

Garcia E. Avaliação das conseqüências da "lei dos agrotóxicos" nas intoxicações e nas classificações toxicológica e de potencial de periculosidade ambiental no período de 1990 a 2000; 2001 [Tese de Doutorado - Faculdade de Saúde Pública da Universidade de São Paulo].

[GARP] Associação Grupo de Analistas de Resíduos de Pesticidas. Manual de resíduos de pesticidas em alimentos. São Paulo; 1999.

[GEMS/FOOD/WHO] Global Environment Monitoring System/Food Contamination and Assessment Program/World Health Organization. Guidelines for predicting dietary intake of pesticides residue (revised). 1997, 33p.

Goreinstein $\mathrm{O}$ e Gutierrez A CEAGESP e o monitoramento de resíduos de agrotóxicos em horticultura. In: Portal CEAGESP. Disponível em URL: $<$ http://www.ceagesp.gov.br>.[2006 abr 05]

Grisolia CK. Fungicidas etileno-bisditiocarbamatos: aspectos de genotoxicidade, carcinogenicidade e teratogenicidade. Pesticidas 1995; 5:19-32. 
Hajslová J, Koccourek V, Jehlicková Z, Davidek J. The fate of ethylenebis(dithiocarbamate) fungicides during processing of contaminated apples. Z. Lebensm Unters Forsch, 1986, 183 (5): 348-51, nov. Disponível em URL: $<$ http://www.bireme.com.br>. [2007 fev 27]

Hanborg JB, Petersen A., Andersen JH, Christensen T. Probabilistic dietary exposure assessmet of Danish consumers to dithiocarbamate pesticide found in food in the monitoring program 1998-2003. In: Book of Abstracts do 6th European Pesticide Residue Workshop; 2006 may 21-25; Corfu. Greece: National Agricultural Research Foundation; 2006. p.57.

Hogendoorn EA, van Zoonen P, Brinkman U. A column-switching RPLC for the trace-level determination of ethylenethiourea in aqueous samples. Chromatographia 1991; 31:285-92.

Hwang ES, Cash, JN, Zabik, MJ. Ozone and hydrogen peroxyacetic acid treatment to reduce or remove EBDCs and ETU residues in a solution. J Agric Food Chem, 2001; 49 (11): 5689-94, nov.

Hwang E, Cash, JN, Zabik, MJ. Chlorine and chlorine dioxide treatment to remove EBDCs and ETU residues in a solution. J Agric Food Chem, 2002; 50 (16): 473442.

[IARC] International Agency for Research on Cancer. Genetic and related effects. IARC Monogr Eval Carcinog Risk Hum Suppl 1987; 6:304-7.

[IARC] International Agency for Research on Cancer, Genetic and related effects. Monographs on the Evaluation of Carcinogenic Risk of Chemicals to Man. $2000 ; 79$.

[IBGE] Instituto Brasileiro de Geografia e Estatística. Sistema IBGE de Recuperação Automática-SIDRA. Disponível em URL:http://www.sidra.ibge. gov.br. [2005 out 25]. 
[IBGE/ENDEF]. Instituto Brasileiro de Geografia e Estatística/Estudo Nacional da Despesa Familiar. Tabelas de composição de alimentos. Estudo Nacional da Despesa Familiar-ENDEF 1985; 3, 216p.

[ICH]. International Conference on Harmonization of Technical Requirements for Registration of Pharmaceuticals for Human Use. Validação of Analytical Procedures: Methodology. Geneva. 1997, p.27463-67.

Iha MH. Suco de maçã: metodologia analítica para determinação de patulina e qualidade físico-química e microbiológica; 2006 [Tese de Doutorado Coordenadoria de Controle de Doenças da Secretaria de Estado da Saúde de São Paulo].

[INMETRO] Instituto Nacional de Metrologia, Normalização e Qualidade Industrial. Orientações sobe validação de Métodos de Ensaios Químicos. DOC-CGCRE-008 Revisão: 01, Brasília,março, 2003.

[JMPR] Joint Meeting of the FAO Panel of Experts on Pesticide Residues in Food and the Environment and the WHO Expert Group on Pesticide Residues; 1993 Sept 20-29; Geneve. Report. Geneva: FAO; 1994. (FAO Plant Production and Protection, 122)

Johannesen H, Nielsen AB, Helweg A, Fomsgaard IS. Degradation of [14 C] ethylenethiourea in surface and subfurface soil. Sci Total Environ 1996; 191(3):271-6.

Kaushik B. Residue dynamics of carbendazim and mancozeb in grape (Vitis Vinifera L.) berries. Toxicological and Environmental Chemistry 2005; 87(1): 77-81(5), Jan-Mar. 
Knio K M, Dagher S, Saad A. The fate and persistence of zineb, maneb, and ethylenethiourea on fresh and processed tomatoes. Food Additives and Contaminants 2000, 17(5): 393-398(6), 1 May.

Kontou D, Tsipi C T. Stability of the dithiocarbamate pesticide maneb in tomato homogenates during cold storage and thermal processing. Food Additives and Contaminants, 2004, 21(11): 1083-89, Nov.

Kautter, M. Comparative pesticide residue test on eight fresh products taken from leading middle-European supermarket chains. Exceeded ARfDs and gaps in the regulation on pestcide residues. In: Book of Abstracts do 6th European

Pesticide Residue Workshop; 2006 may 21-25; Corfu. Greece: National Agricultural Research Foundation; 2006. p.19.

Kovaleski A, Sanhueza RMV. Ribeiro LG, Becher W, Boneti, I.S, Katsurayama Y, Protas JF. Resultados de pesquisa da produção integrada da maçã (PIM). In: Anais Bento Gonçalves: Embrapa Uva e Vinho Seminário Brasileiro de Produção Integrada de Frutas; 2000 fev: Bento Gonçalves: Gilmar Ribeiro Nachtigall e Ana Beatriz Costa Czermainski, 2000 (28):87-94.

Kumar U, Agarwal HC. Degradation of dithane M-45 residues in brinjals during cooking. Bull Environ Contm Toxicol 1991; 47:725-31.

Kurttio P, Savolainen K, Tuominem R, Kosma $\mu$ g, Naukkarinen A, Mlnnistn P, Collan Y. Ethylenethiourea and nabam induced alterations of function and morphology on thyroid gland in rats. Arch toxicol Suppl 1986; 9: 339-44.

Kurttio P, Vartianen T, Savolaimen K. Envrironmental and biological monitoring of exposure to ethylenebisdithiocarbamate fungicides and ethylenethiourea. Br J Ind Med 1990; 47(3): 203-6.

Larini L. Toxicologia. Barueri: Manole, 1999. 
Lemes VRR Avaliação de resíduos de ditiocarbamatos e etilenotiouréia (ETU) em fruta e sua implicação na saúde pública. São Paulo; 2003. [Dissertação de Mestrado- Faculdade de Saúde Pública da Universidade de São Paulo].

Lemes VRR, Barretto HHC, Kussumi, TA, Colacioppo S. Avaliação de resíduos de ditiocarbamatos e etilenotiouréia (ETU) em fruta e sua implicação na saúde pública. Rev Inst Adolfo Lutz 2005; 64(1):50-7.

Lentza RC, Ethyleneyhiourea (ETU) in relation to use of ethylenebisdithiocarbamate (EBDC) fungicides. Rev Environ Contm Toxicol 1990; 115:1-37.

Looser N, Zipper, H, Kostelac, D, Scherbaum E, Anastassiades, M. Pesticide residues in strawberries sampled from the market of the German state of BadenWürttemberg in the period between 2002 and 2005. In: Book of Abstracts do 6th European Pesticide Residue Workshop; 2006 may 21-25; Corfu. Greece: National Agricultural Research Foundation; 2006. p.95.

[MAFF] Ministry of Agriculture, Fisheries \& Food. Advisory Committee on Pesticides. Position document on consumer risk arising from the use of ethylene bisdithiocarbamates. London: 1990.

Marshall WD. Preprocessing oxidative washes with alkaline hypochlorite to remove ethylenebis (dithiocarbamate) fungicide residues from tomatoes and greenbeans. $\mathbf{J}$ Agric Food Chem 1982; 30:649-52.

Martins HAJ. Estudo de determinação de resíduos de glifosato e ácido aminometilfosfônico (AMPA) em amostras de soja e água usando cromatografia líquida acoplada à espectrometria de massas em tandem com ionização por electrospray (LC-ESI/MS/MS). São Paulo; 2005. [Dissertação de MestradoInstituto de Pesquisas Energéticas e Nucleares-Autarquia associada à Universidade de São Paulo]. 
Mestres R, Mestres G. Ethylenebisdithiocarbamate and ethylenethiourea residues in food. Rev Bras Toxicol 1991; 4(1/2):11-8.

[MAPA 2005] Brasil: Maçã-produção, área colhida e rendimento médio-1900 a 2003. MAPA. Secretaria de Política Agrícola. Brasil: Maçã-exportações, importações e principais países, produtos selecioanados - 1996 a 2003. Disponível em URL: http://www.agricultura.gov.br/pls/portal/docs/PAGE/MAPA/ ESTATISTICAS/AGRICULTURA_EM_NUMEROS_2003/3.1.01.G.XLS [2005 jul 25]

[MAPA 2007a]. Brasil. Secretaria de Política Agrícola. Notícia de 24/07/2006. Zoneamento Agrícola cresce 85\% entre 2003 e 2006. Disponível em URL $<$ http.//extranet.agricultura.gov.br $>$ [2007 jan 11].

[MAPA 2007b] Brasil. Ministério da Agricultura. Notícia de 10/01/2007. Exportações do agronegócio brasileiro aumentaram 99\% em cinco anos no período de 2002 a 2006. Disponível em URL: http://extranet.agricultura.gov.br/pubcs_cons/!ap_detalhe_notícia_cons_web?p_id_p ublicação=922_[2007 jan 11].

[MAPA 2007c].Ministério da Agricultura: Brasil: Maçã-produção, área colhida e rendimento médio - 1990 a 2005. Disponível em URL: <http:// www.agricultura.gov.br/pls/portal/docs/PAGE/MAPA/ESTATÍSTICAS/AGRICULTURA_em_NUMEROS_2005/03.01.12> [2007 jan 16]

[MAPA 2007d].Ministério da Agricultura: Brasil: Maçã-exportações, importações e principais países, produtos selecionados-1996 a 2004. Disponível em <URL: http://www.agricultura.gov.br/pls/portal/docs/PAGE/MAPA/ESTATÍSTICAS/AGRI CULTURA_em_NUMEROS_2005/03.01.12> [2007 jan 16]

[MAPA 2007e] Brasil. Ministério da Agricultura. Notícia de 23/11/2004. Agronegócio Brasileiro: Uma oportunidade de investimento. Disponível em $\underline{\mathrm{URL}}:<\mathrm{http}: / /$ www.agricultura.gov.br $>[2007$ jan 19]. 
[MAPA/AGROFIT] Ministério da Agricultura. Consulta de ingrediente ativo. Disponível em URL: $<$ http://extranet.agricultura.gov.br/agrofit_cons!ap_ing_ativo_ lista_cons $>$ [2005 jul 25].

Ministério da Saúde. Promoção da saúde: Declaração de Alma-Ata, Carta de Ottawa, Declaração de Adelaide, Declaração de Sundsvall, Declaração de Santa Fé de Bogotá, Declaração de Jacarta, Rede de Megapaíses e Declaração do México. Brasília; 2001.

Ministério da Saúde. Agência Nacional de Vigilância Sanitária. Resolução-RE $n^{\circ}$ 165, de 29 de agosto de 2003. Determina a publicação do "Índice das monografias dos ingredientes ativos de agrotóxicos, domissanitários e preservantes de madeira", cujo emprego encontra-se autorizado conforme descrito no Anexo I, disponiblizadas no endereço eletrônico: http://www.anvisa.gov.br/toxicologia/index.htm. Revoga a Portaria $\mathrm{n}^{\circ} 10$, de 08 de março de 1985 e todas aquelas que a complementaram ou suplementaram. Diário Oficial da União, Brasília, 02 de set. 2003. p.48-50.

Monteiro, L B. Manejo integrado de pragas em macieiras no Rio Grande do Sul. II Uso de Neosiulus californicus para o controle de Panonuchus ulmi. Rev. Brás.Frutic. 2002, 24:2.

Monteiro, L B; Souza, A ; Belli, E L et al. Ocorrência de Trichogramma pretiosum Riley (Hymenoptera: Trichogrammatidae) em ovos de Bonogota cranaodes ( Meyrick) (Lepidóptera: Tortricidae) em macieira. Rev. Bras. Frutic. 2004, 26(1):.171-72.

Nebbia C, Ferrero E, Valenza F, Castagnaro M, Re G, Soffietti MG. Pathologic changes, tissue distribution and extent of conversion to ethylenethiourea after subacute administration of zinc ethylene-bis-dithiocarbamate (zineb) to calves with immature rumen function. Am J Vet Res 1991; 52:1717-22. 
Neil GD, Wiliams JS. Ethylenethiourea in Maine ground water: report. Maine: Department of Conservation; 1990.

Newsome WH. Determination of ethylenethiourea residues im apples. J Agric Food Chem 1972; 20:967-9.

Neves EM, Dayoub, M, Dragone, DS. Análise da demanda por defensivos pela fruticultura brasileira. Rev Bras Frutic 2002;.24 (3):1997-2000. Disponívl em URL: $<$.http://www.scielo.br/scielo.php?script=sci_arttex\&pid=SS0100-453002000300031 $\& \operatorname{Ing}>[2005$ jul 26].

[NIOSH /RTECS] National Institute for Occupational Safety and Health/ Registry of Toxic Effects of Chemical Substances. 2-Imidazolidinethione. Disponível em <URL:http://www.cde/niosh/rtecs/ni92dda8.html [2007 jan 11].

Oliveira ELC. Estudo da inervação motora e entérica, da musculatura da pelve e das alterações sacrais em fetos de ratos com anomalia anorretal induzida pela etilenotiouréia. Ribeirão Preto; 2005. [Tese de Doutorado-Faculdade de Medicina de Ribeirão Preto da Universidade de São Paulo]. In: Resumos de dissertações de mestrado e teses de doutorado apresentadas na Faculdade de Medicina de Ribeirão Preto-USP, Medicina 2005a:38(3/4):317-18,jul/dez.. Disponível em URL: $<$ http://www.fmrp.usp.br/revista/2005/vol38n3e4/teses38n.3e4pdf> [2007 jan 19]

Oliveira-Filho EC. Segurança de agentes microbiológicos para o controle de pragas: avaliação toxicológica, regulamentação e situação atual. Revista Brasileira de Toxicologia 2005b, 18(1): 71-75.

Oliveira JJV, Toledo MCF. Resíduos de agrotóxicos em morangos. Pesticidas, 1995; 595-1110.

Oliveira M.E. e Manica, I. Principais países e quantidades de frutas produzidas no mundo. Toda Fruta .disponível em URL: $<$ http://www.todafruta.com.br/todafruta/ mostra_conteúdo.asp?conteudo $=9773>[2005$ jul 26]. 
Onley JH, Giuffrida LH, Ives NF, Watts RR, Storherr RW. Gas liquid chromatography and liquid chomatography of ethylenethiourea in fresh vegetable crops, fruits, milk and cooked foods. J AOAC 1977; 60:1105-10.

Pereira EC. Resíduos de fungicidas orgânicos do grupo dos ditiocarbamatos em frutas e outros produtos de origem vegetal. Rev Soc Bras Toxicol 1988; 1(1/2):41-3.

Pereira RGL. Critérios de avaliação do risco de praguicidas em alimentos vegetais como ferramenta de gerenciamento da segurança alimentar no Brasil. São Paulo; 2005. [Dissertação de Mestrado - Faculdade de Ciências Farmacêuticas da Universidade de São Paulo].

Peres F, Silva JJO, Della-Rosa HV, Lucca SR. Desafios ao estudo da contaminação humana e ambiental por agrotóxicos. Ciênc. saúde coletiva 2005; 10 (suppl.), Sept./Dec.

[PSD] Pesticides Safety Directorate. Pesticide Safety Diretorate Home Page. Registering a Pesticide. Data Requirements Handbook and Suppementary Guidance. Disponível em URL: http://www.pesticides.gov.uk [2004 dez 04].

Reis MRCS, Caldas LQA. Dithicarbamate residues found on vegetables and fruit marketed in the State of Rio de Janeiro, Brazil. Ciênc Cult 1991; 43 (3):212-8.

Richardson M. Pesticides - friend or foe? Wat Sci Technol 1998; 37(8):19-25.

Ripley BD, Cox DF. Residues of ethylenebis(dithiocarbamate) and ethylenethiourea in treated tomatoes and commercial tomato products. J Agric Food Chem 1978; 26:1137-43. 
Rodriguez, JÁ, Lamoth, L. Contaminación de alimentos de origen agrícola com resíduos de plaguicidas em Panamá. Panamá, 1994;s.n.: ago, 15p.

Ross DG, Grosby G. Phytolysis of ethylenethiourea. J Agric Food Chem 1973; 21:335-7.

Ruggiero C. Colheita de mamão. 1980. Disponível em URL:http://www.todafruta.com.br[2003 abr 6].

Sannino A, Bolzoni L, Bandini M. Application of liquid chromatography with electrospray tandem mass spectrometry to the determination of a new generation of pesticides in processed fruits and vegetables. Journal of Chromatography A: 2004 (1036):161-169. São Paulo. Secretaria de Estado da Saúde. Centro de Vigilância Sanitária. Portaria Conjunta CVS/IAL s/no , de 18 de fevereiro de 2005. Relatório Final do Programa Paulista de Análise Fiscal de Alimentos Biênio 2003-2004. Diário Oficial do Estado de São Paulo, São Paulo, 19 de fev. 2005, Poder Executivo, Seção I, 115 (33): 33-44.

[SEAGRI]. Torralles M E. Bahia apta a exportar mamão. Jornal A Tarde, 28/01/2004. Disponível em URL: <http://www.seagri.ba.gov.br/ notícias.asp? qact=view\&notid=1457>. [2005 jul 25].

Silva EMF da, coordenador. Estudo sobre o mercado de frutas. Brasília. FIPE, 1999.

Silva JM, Silva EM, Faria HP, Pinheiro TMM. Agrotóxico e trabalho: uma combinação perigosa para a saúde do trabalhador rural. Ciênc. saúde coletiva 2005;10 (4), Oct./Dec. Disponível em URL:

[SINDAG] Sindicato Nacional da Indústria de Produtos para Defesa Agrícola. Número e percentagem de ingrediente ativo em linha de comercialização, 
Consumo de defensivos agrícolas. Disponível em

<URL:http://www.sindag.com.br> [2007 jan 11].

Soares IAA, Goulart MCP, Queiroz RL, Mello SMM, Ávila JT, Azevedo SF. Resíduos de fungicidas orgânicos do grupo dos ditiocarbamatos em frutas e hortaliças. Minas Gerais: Secretaria de Estado da Agricultura e Pecuária; 1987. p. 99-100.

Soares WL. Produtividade e Saúde do Trabalhador Rural: Uma Análise CustoBenefício do Uso de Agrotóxicos em Minas Gerais. Belo Horizonte. 2001. [Dissertação de Mestrado do Centro de Desenvolvimento e Planejamento Regional, Universidade Federal de Minas Gerais].

Soares W, Moritz R, Almeida VR, Moro S. Trabalho rural e fatores de risco associados ao regime de uso de agrotóxicos em Minas Gerais, Brasil. Cad. Saúde Pública, 2003; 19 (4), Jul./Aug. Disponível em URL: <http://www.scielo.br/ scielo.php> [2007 jan 19].

Souza SVC, Junqueira RG. A procedure to assess linearity by ordinary least squares method. Analytica Chimica Acta. 2005; 552: 25-35.

Souza SVC. Procedimento para validação intralaboratorial de métodos de ensaio: delineamento e aplicabilidade em análises de alimentos. Belo Horizonte, 2007. [Tese de Doutorado - Faculdade de Farmácia da Universidade Federal de Minas Gerais].

[SRJUNDIAÍ] Sindicato Rural de Jundiaí. A Cultura da Macieira no Estado de São Paulo. Disponível em < URL: http://www.srjundiai.com.br/macieira.htm> [2005a jul 26].

[SRJUNDIAÍ] Sindicato Rural de Jundiaí. A cultura do morangueiro. Disponível em < URL: http://www.srjundiai.com.br/cultmoran.htm> [2005b jul 26]. 
Stoppelli IMBS. Agricultura, ambiente e saúde: uma abordagem sobre o risco do contato com os agrotóxicos a partir de um registro hospitalar de referência regional. 2005.[Tese de doutorado. Centro de Recursos Hídricos e Ecologia Aplicada, Escola de Engenharia de São Carlos, Universidade de São Paulo].

Toledo HHB, Steling CM, Gojtan Jr E, Baptista GC, Aleluia, I, Lange Jr L et al. Manual: critérios mínimos para a condução de estudos de resíduos. São Paulo: GARP; 2002. 2 Pt.

Tomlin C. The pesticide manual United Kingdom. $10^{\text {th }}$ ed. Cambridge: British Crop. Protection Council; 1995.

Trindade AV. O cultivo do mamão. Cruz das Almas: Embrapa-Mandioca e Fruticultura; 1999. (Circular Técnica, 34).

Trindade AV. Mamão produção: aspectos técnicos. Cruz das Almas: Embrapa Mandioca e Fruticulura; 2000. (Série Frutas do Brasil, 3).

Triverdi N, Kakkar R, Srivastava MK, Mithal A, Rauzadam RB. Effect of oral administration of fungicide-mancozeb on thyroid gland of rat. Indian J Exp Biol 1993; 31: 564-6.

Van Der Poll JM, Versluis-de Haan GG, De Wilde O. Determination of ethylenthiourea in water samples by gas chromatography with alkali flame ionization detection and mass spectrometric confirmation. J Chromatogr 1993; 643:163-8.

Van Leeuwen CJ, Maas-Diepeveen JL, Niebeek G, Vergouw WHA, Griffioen PS, Luijken MW. Aquatic toxicological aspects of dithiocarbamates and related compounds. I. Short-term toxicity tests. Aquat Toxicol 1985a; 7:145-64.

Van Leeuwen CJ, Moberts F, Niebeek G. Aquatic toxicological aspects of dithiocarbamates and related compouns. II. Effects on survival, reproduction and growth of Daphina Magna. Aquat Toxicol 1985b; 7:165-75. 
Veiga MM, Silva DM, Veiga LBL, Faria MVC. Análise da contaminação dos sistemas hídricos por agrotóxicos numa pequena comunidade rural do Sudeste do Brasil. Cad. Saúde Pública 2006: 22 (11) nov. Disponível em URL: $<$ http://scielo.br $>$ [2007 jan 11].

Vetorazzi G, Almeida WF, Burin GJ, Jaeger RB, Puga FR, Rahde AF et al. International safety assessment of pesticidas: dithiocarbamate pesticides, ETU, and PTU - a review and update. Teratog Carcinog Mutagen 1995; 15:313-37.

[WHO] World Health Organization. Environmental Health Criteria 78 Dithiocarbamate pesticides, ethylenethiourea, and propylenethiourea: a general introduction. Geneva; 1988.

Wilson JS, Otsuki T. To spray or not to spray: pesticides, banana exports, and food safety. Food Policy 2004, 29:131-46.

Yoshida A, Harada T, Maita K. Tumor induction by concurrent oral administration of ethylenethiourea and sodium nitrite im mice. Toxicol Pathol 1993; 21:303-1.

Yoshida A, Harada T, Hayashi S, Mori I, Miyajima H, Maita K. Endometrial carcinogenesis induced by concurrent oral administration of ethylenethiourea and sodium nitrite in mice. Carcinogenesis 1994; 15:2311-8. 
Anexo 1 - Ingredientes ativos de agrotóxicos registrados para uso em maçã, mamão e morango

\begin{tabular}{|c|c|c|c|c|c|}
\hline \multirow[t]{2}{*}{ Nome comum } & \multirow[t]{2}{*}{ Grupo Químico } & \multirow[t]{2}{*}{ Classe } & \multicolumn{3}{|c|}{ Registrado para uso (X) } \\
\hline & & & maçã & mamão & morango \\
\hline Abamectina & avemectina & Acaricidas/inseticidas & $\mathrm{x}$ & $\mathrm{x}$ & $\mathrm{x}$ \\
\hline $\begin{array}{l}\text { Acetato de }(\mathrm{E}, \mathrm{Z})-3,5 \\
\text { dodecadienila }\end{array}$ & Acetato insaturado & Feromônio sintético & $\mathrm{x}$ & & \\
\hline Acetato de (E)-8-dodecenila & Acetato insaturado & Feromônio sintético & $\mathrm{x}$ & & \\
\hline Acetato de (Z)-8-dodecenila & Acetato insaturado & Feromônio sintético & $\mathrm{x}$ & & \\
\hline Acetato de (Z)-9-dodecenila & Acetato insaturado & Feromônio sintético & $\mathrm{x}$ & & \\
\hline Álcool laurílico & Álcool sintético & Feromônio sintético & $\mathrm{x}$ & & \\
\hline Amitraz & Bis(arilformamidina) & Acaricidas/inseticidas & $\mathrm{x}$ & & \\
\hline Azociclotina & Organoestânico & Acaricidas & $\mathrm{x}$ & & \\
\hline Azoxistrobina & estrobilurina & Fungicidas & & $\mathrm{x}$ & $\mathrm{x}$ \\
\hline Bitertanol & triazol & Fungicidas & $\mathrm{x}$ & & \\
\hline Brometo de metila & Alifático halogenado & $\begin{array}{l}\text { Formicidas/fungicidas/herbici } \\
\text { das/inseticidas//nematicidas }\end{array}$ & $\mathrm{x}$ & $\mathrm{x}$ & $\mathrm{x}$ \\
\hline Captana & dicarboximida & Fungicidas & $\mathrm{x}$ & & \\
\hline Carbaril & Metilcarbamato de naftila & $\begin{array}{l}\text { Inseticidas/reguladores de } \\
\text { crescimento }\end{array}$ & $\mathrm{x}$ & & \\
\hline
\end{tabular}




\begin{tabular}{|c|c|c|c|c|c|}
\hline \multirow[t]{2}{*}{ Nome comum } & \multirow[t]{2}{*}{ Grupo Químico } & \multirow[t]{2}{*}{ Classe } & \multicolumn{3}{|c|}{ Registrado para uso (X) } \\
\hline & & & maçã & mamão & morango \\
\hline Carbosulfano & Metilcarbamato de benzofuranila & $\begin{array}{l}\text { Acaricidas/inseticidas/nemati } \\
\text { cidas }\end{array}$ & & $\mathrm{x}$ & \\
\hline Cihexatina & organoestânico & Acaricidas & $\mathrm{x}$ & & $\mathrm{x}$ \\
\hline Ciproconazol & triazol & Fungicidas & $\mathrm{x}$ & & \\
\hline Ciprodinil & anilinopirimidina & Fungicidas & $\mathrm{x}$ & & \\
\hline Clofentezina & tetrazina & Acaricidas & $\mathrm{x}$ & $\mathrm{x}$ & $\mathrm{x}$ \\
\hline Clorotalonil & isoftalonitrila & Fungicidas & $\mathrm{x}$ & $\mathrm{x}$ & \\
\hline Clortaldimetílico & Ácido benzeno dicarboxilico substituído & Herbicidas & & & $\mathrm{x}$ \\
\hline Clorfenapir & Análogo de pirazol & Acaricidas/inseticidas & & $\mathrm{x}$ & \\
\hline Codlelure & Álcool polinsaturado & Feromônio sintético & $\mathrm{x}$ & & \\
\hline Cresoxim-metílico & estrobilurina & Fungicidas & $\mathrm{x}$ & & \\
\hline Deltametrina & piretróide & Inseticidas & $\mathrm{x}$ & & \\
\hline Diazinona & Organofosforado & Acaricidas/inseticidas & $\mathrm{x}$ & & \\
\hline Dicofol & organoclorado & Acaricidas & $\mathrm{x}$ & & \\
\hline Dimetoato & Organofosforado & Acaricidas/inseticidas & $\mathrm{x}$ & & \\
\hline Difeconazol & triazol & Fungicidas & $\mathrm{x}$ & $\mathrm{x}$ & $\mathrm{x}$ \\
\hline Dinocape & dinitrofenol & Acaricidas/fungicidas & $\mathrm{x}$ & & \\
\hline
\end{tabular}




\begin{tabular}{|c|c|c|c|c|c|}
\hline \multirow[t]{2}{*}{ Nome comum } & \multirow[t]{2}{*}{ Grupo Químico } & \multirow[t]{2}{*}{ Classe } & \multicolumn{3}{|c|}{ Registrado para uso (X) } \\
\hline & & & maçã & mamão & morango \\
\hline Ditianona & quinona & Fungicidas & $\mathrm{x}$ & & \\
\hline Dodina & guanidina & Fungicidas & & & $\mathrm{x}$ \\
\hline Enxofre & inorgânico & Acaricidas/fungicidas & $\mathrm{x}$ & $\mathrm{x}$ & $\mathrm{x}$ \\
\hline Espirodiclofeno & cetoenol & Acaricidas & & $\mathrm{x}$ & \\
\hline Etiona & organofosforado & Acaricidas/inseticidas & $\mathrm{x}$ & & \\
\hline Famoxadona & oxazolidinadiona & Fungicidas & & $\mathrm{x}$ & \\
\hline Fenpiroximato & pirazol & Acaricidas & & $\mathrm{x}$ & $\mathrm{x}$ \\
\hline Fenpropatrina & piretróide & Acaricidas/inseticidas & $\mathrm{x}$ & & $\mathrm{x}$ \\
\hline Fentiona & organofosforado & $\begin{array}{l}\text { Acaricidas/cupinicidas/formic } \\
\text { idas/inseticidas }\end{array}$ & $\mathrm{x}$ & & \\
\hline Fluazinam & fenilpiridinilamina & Acaricidas/fungicidas & & & $\mathrm{x}$ \\
\hline Hidróxido de cobre & inorgânico & Bactericidas/fungicidas & & $\mathrm{x}$ & $\mathrm{x}$ \\
\hline Glifosato & Glicina substituída & Herbicidas & $\mathrm{x}$ & & \\
\hline Glifosato sal de isopropilamina & Glicina substituída & Herbicidas & $\mathrm{x}$ & & \\
\hline
\end{tabular}




\begin{tabular}{|c|c|c|c|c|c|}
\hline \multirow[t]{2}{*}{ Nome comum } & \multirow[t]{2}{*}{ Grupo Químico } & \multirow[t]{2}{*}{ Classe } & \multicolumn{3}{|c|}{ Registrado para uso (X) } \\
\hline & & & maçã & mamão & morango \\
\hline Glufosinato-sal de amônio & Homoalamina substituída & $\begin{array}{l}\text { Herbicidas/reguladores de } \\
\text { crescimento }\end{array}$ & $\mathrm{x}$ & & \\
\hline Imazalil & imidazol & Fungicidas & & $\mathrm{x}$ & \\
\hline Imibenconazol & triazol & Fungicidas & & & $\mathrm{x}$ \\
\hline Iprodione & dicarboximida & Fungicidas & & & $\mathrm{x}$ \\
\hline Malationa & Organofosforado & Acaricidas/inseticidas & & & $\mathrm{x}$ \\
\hline Mancozebe & Alquilenobis(ditiocarbamato) & Acaricidas/fungicidas & & $\mathrm{x}$ & \\
\hline Manebe & Alquilenobis(ditiocarbamato) & Fungicidas & & $\mathrm{x}$ & \\
\hline Metam-sódico & Isotiocianato de metila (precursor de) & $\begin{array}{l}\text { Formicidas/fungicidas/herbici } \\
\text { das/inseticidas//nematicidas }\end{array}$ & & & $\mathrm{x}$ \\
\hline Mevinfós & Organofosforado & Acaricidas/inseticidas & & & $\mathrm{x}$ \\
\hline Oxicloreto de cobre & inorgânico & Bactericitas/fungicidas & & $\mathrm{x}$ & $\mathrm{x}$ \\
\hline Oxicloreto de paraquat & bipiridilio & Herbicidas & $\mathrm{x}$ & & \\
\hline Òxido cuproso & Inorgânico & Bactericitas/fungicidas & & $\mathrm{x}$ & $\mathrm{x}$ \\
\hline Propargito & Sulfito de alquila & Acaricidas & & & $\mathrm{x}$ \\
\hline Simazina & triazina & Herbicidas & $\mathrm{x}$ & & \\
\hline
\end{tabular}




\begin{tabular}{|c|c|c|c|c|c|}
\hline \multirow[t]{2}{*}{ Nome comum } & \multirow[t]{2}{*}{ Grupo Químico } & \multirow[t]{2}{*}{ Classe } & \multicolumn{3}{|c|}{ Registrado para uso (X) } \\
\hline & & & maçã & mamão & morango \\
\hline Tetradifona & clorodifenilsulfona & Acaricidas & & $\mathrm{x}$ & \\
\hline Tiacloprido & neonicotinóide & Inseticidas & & $\mathrm{x}$ & \\
\hline Tiametoxan & neonicotinóide & inseticidas & & $\mathrm{x}$ & $\mathrm{x}$ \\
\hline Trimedure & Ésteres saturados & Feromônio sintético & & $\mathrm{x}$ & \\
\hline (Z|)-8-dodecenol & Álcool insaturado & Feromônio sintético & $\mathrm{x}$ & & \\
\hline
\end{tabular}

Fonte: MAPA/AGROFIT (2005) 
Anexo 2 - Redes de supermercados onde foram adquiridas as amostras.

\begin{tabular}{|l|}
\hline Armazém Hirota Ltda; \\
\hline Casa Santa Luzia Importação Ltda; \\
\hline Carrefour Consensus Comércio Varejista de Produtos Alimentícios Ltda; \\
\hline Compre Bem (Cia. Brasileira de Distribuição); \\
\hline Dia Brasil Sociedade Ltda; \\
\hline Dias Pastorinho S.A. Com. e Ind., Econ Distribuição S.A.; \\
\hline Eldorado S.A., Extra (Cia. Brasileira de Distribuição); \\
\hline Futurama Supermercado Ltda; \\
\hline Hipermercado Bergamini; \\
\hline Luzita Ind. e Com. Ltda.; \\
\hline Mercado Monte Alverne Ltda.; \\
\hline Pão de Açúcar (Cia Brasileira de Distribuição); \\
\hline Portal Com. e Ind. Ltda.; \\
\hline Sé Supermercados Ltda.; \\
\hline Sam's Club Wal-Mart Brasil Ltda.; \\
\hline Sonda Supermercados Exp. e Imp.Ltda.; \\
\hline Supermercado Higa \& Filhos Ltda.; \\
\hline Supermercado do Carmo Ltda; \\
\hline Supermercado Fluminense Ltda.; \\
\hline Supermercado K-Tem Ltda.; \\
\hline Supermercado Líder do Carrão Ltda. \\
\hline
\end{tabular}


Anexo 3 - Resultado das amostras de maçã de acordo com local, zona, estação do ano

\begin{tabular}{|c|c|c|c|c|c|}
\hline variedade & Local & Zona & Estação & $\begin{array}{l}\text { Resultado } \\
\text { LC/UV }\end{array}$ & $\begin{array}{l}\text { Resultado } \\
\text { LC/MS/MS } \\
(\mu \mathrm{g} / \mathrm{kg})\end{array}$ \\
\hline Controle & Vila Clementino & Sul & outono & $<\mathrm{LD}$ & $<\mathrm{LD}$ \\
\hline Red & Pinheiros & Oeste & Verão & $<\mathrm{LD}$ & $<\mathrm{LQ}$ \\
\hline Fuji & Vila Carrão & Leste & Verão & $<$ LD & 0.97 \\
\hline Red. & Tatuapé & Leste & Verão & $<\mathrm{LD}$ & $<\mathrm{LQ}$ \\
\hline Red & Santana & Norte & Verão & $<\mathrm{LD}$ & $<\mathrm{LQ}$ \\
\hline Gala & Tucuruvi & Norte & Verão & $<\mathrm{LD}$ & $<\mathrm{LQ}$ \\
\hline Gala & Saúde & Sul & Verão & $<\mathbf{L D}$ & 1,01 \\
\hline Gala & Vila Clementino & Sul & Verão & $<\mathbf{L Q}$ & 1,47 \\
\hline Gala & Sta Cecília & Centro & Outono & $<\mathbf{L Q}$ & 1,46 \\
\hline Gala & Perdizes & Oeste & Outono & $<\mathbf{L Q}$ & 2,65 \\
\hline Fuji & Aricanduva & Leste & Outono & $<\mathbf{L Q}$ & 1,09 \\
\hline Gala & São Mateus & Leste & Outono & $<\mathrm{LD}$ & $<\mathrm{LQ}$ \\
\hline Gala & Mirandópolis & Sul & Outono & $<\mathrm{LD}$ & $<\mathrm{LQ}$ \\
\hline Gala & Vila Mariana & Sul & Outono & $<\mathbf{L Q}$ & 1,57 \\
\hline Gala & Bela Vista & Centro & Outono & $<\mathrm{LQ}$ & $<\mathrm{LQ}$ \\
\hline Fuji & Liberdade & Centro & Outono & $<\mathrm{LD}$ & $<\mathrm{LQ}$ \\
\hline Fuji & Vila Guilherme & Norte & Outono & $<\mathrm{LD}$ & $<\mathrm{LQ}$ \\
\hline Fuji & Jabaquara & Sul & Inverno & $<\mathrm{LD}$ & $<\mathrm{LQ}$ \\
\hline Fuji & Belém & Leste & Inverno & $<\mathrm{LQ}$ & $<\mathrm{LQ}$ \\
\hline Gala & Barra Funda & Oeste & Inverno & $<\mathrm{LD}$ & $<\mathrm{LQ}$ \\
\hline Gala & Consolação & Centro & Inverno & $<\mathrm{LD}$ & $<\mathrm{LQ}$ \\
\hline Gala & Parada Inglesa & Norte & Inverno & $<\mathrm{LD}$ & $<\mathrm{LQ}$ \\
\hline Fuji & $\begin{array}{l}\text { Alto de } \\
\text { Pinheiros }\end{array}$ & Oeste & Inverno & $<\mathrm{LD}$ & $<\mathrm{LQ}$ \\
\hline Gala & Vila Matilde & Leste & Inverno & $<\mathbf{L Q}$ & 2,77 \\
\hline Fuji & Butantã & Oeste & Primavera & $<\mathbf{L Q}$ & 3,68 \\
\hline
\end{tabular}




\begin{tabular}{|c|c|c|c|c|c|}
\hline \multicolumn{6}{|c|}{$\begin{array}{l}\text { Continuação do Anexo } 3 \text { - Resultado das amostras de } \mathbf{r} \\
\text { local, zona, estação do ano }\end{array}$} \\
\hline Variedade & Local & Zona & Estação & $\begin{array}{l}\text { Resultado } \\
\text { LC/UV }\end{array}$ & $\begin{array}{l}\text { Resultado } \\
\text { LC/MS/MS } \\
(\mu \mathrm{g} / \mathrm{kg})\end{array}$ \\
\hline Gala & Jardim São Paulo & Norte & Primavera & $<\mathrm{LD}$ & $<\mathrm{LD}$ \\
\hline 28 (Fuji) & Bela Vista & Centro & Primavera & $<\mathrm{LD}$ & $<\mathrm{LQ}$ \\
\hline 30 (Gala) & Santa Cecília & Centro & Primavera & $<\mathrm{LD}$ & $<\mathrm{LQ}$ \\
\hline 31 (Fuji) & Santo Amaro & Sul & Primavera & $<\mathrm{LD}$ & $<\mathrm{LQ}$ \\
\hline 32 (Fuji) & Jaçanã & Sul & Primavera & $<\mathrm{LD}$ & $<\mathrm{LQ}$ \\
\hline 33 (Fuji) & Penha & Leste & Primavera & $<\mathrm{LD}$ & $<\mathrm{LQ}$ \\
\hline 34 (Fuji) & Parque do Carmo & Leste & Primavera & $<\mathrm{LD}$ & 3,04 \\
\hline
\end{tabular}


Anexo 4 - Resultado das amostras de mamão (Papaya carica $L$ ), de acordo com local, zona, estação do ano

\begin{tabular}{|c|c|c|c|c|}
\hline Local & Zona & Estação & $\begin{array}{l}\text { Resultado } \\
\text { LC/UV }\end{array}$ & $\begin{array}{l}\text { Resultado } \\
\text { LC/MS/MS } \\
(\mu \mathrm{g} / \mathrm{kg})\end{array}$ \\
\hline Jardim Paulista & Oeste & Verão & $<\mathrm{LQ}$ & 1,01 \\
\hline Vila Carrão & Leste & Verão & $<\mathrm{LD}$ & $<\mathrm{LQ}$ \\
\hline Tatuapé & Leste & Verão & $<\mathrm{LQ}$ & 2,71 \\
\hline Santana & Norte & Verão & $<\mathrm{LQ}$ & 1,69 \\
\hline Tucuruvi & Norte & Verão & $<\mathrm{LD}$ & $<\mathrm{LQ}$ \\
\hline Saúde & Sul & Verão & $<\mathrm{LQ}$ & 1,37 \\
\hline Vila Clementino & Sul & Verão & $<L Q$ & 1,49 \\
\hline Santa Cecília & Centro & Outono & $<$ LD & 1,32 \\
\hline Perdizes & Oeste & Outono & $<\mathrm{LD}$ & $<\mathrm{LD}$ \\
\hline Aricanduva & Leste & Outono & $<L Q$ & 1,05 \\
\hline São Mateus & Leste & Outono & $<$ LD & 1,24 \\
\hline Mirandópolis & Sul & Outono & $<$ LD & 1,41 \\
\hline Vila Mariana & Sul & Outono & $<\mathrm{LQ}$ & $<\mathrm{LQ}$ \\
\hline Pinheiros & Oeste & Outono & $<$ LD & 1,59 \\
\hline Liberdade & Centro & Outono & $<\mathrm{LQ}$ & 1,23 \\
\hline Vila Guilherme & Norte & Outono & $<\mathrm{LQ}$ & 1,38 \\
\hline Jabaquara & Sul & Inverno & $<\mathrm{LD}$ & $<\mathrm{LQ}$ \\
\hline Belém & Leste & Inverno & $<\mathrm{LQ}$ & 4,21 \\
\hline Barra Funda & Oeste & Inverno & $<\mathrm{LD}$ & $<\mathrm{LQ}$ \\
\hline Consolação & Centro & Inverno & $<L Q$ & 2,74 \\
\hline Parada Inglesa & Norte & Inverno & $<\mathrm{LQ}$ & 3,13 \\
\hline Alto de Pinheiros & Oeste & Inverno & $<\mathrm{LQ}$ & 1,99 \\
\hline Vila Matilde & Leste & Inverno & $<\mathrm{LD}$ & $<\mathrm{LQ}$ \\
\hline Butantã & Oeste & Primavera & $<\mathrm{LQ}$ & 1,83 \\
\hline $\begin{array}{l}\text { Jardim } \\
\text { São Paulo }\end{array}$ & Norte & Primavera & $<\mathrm{LQ}$ & 3,94 \\
\hline
\end{tabular}




\begin{tabular}{|l|l|l|l|l|}
\hline \multicolumn{5}{|c|}{$\begin{array}{c}\text { Continuação do Anexo 4 - Resultado das amostras mamão } \\
\text { (Papaya carica L), de acordo com local, zona, estação do ano }\end{array}$} \\
\hline Local & Zona & Estação & $\begin{array}{l}\text { Resultado } \\
\text { LC/UV }\end{array}$ & $\begin{array}{l}\text { Resultado } \\
\mathbf{L C} / \mathrm{MS} / \mathrm{MS} \\
(\boldsymbol{\mu g} / \mathbf{k g})\end{array}$ \\
\hline Bela Vista & Centro & Primavera & $<\mathrm{LD}$ & $<\mathrm{LQ}$ \\
\hline Santo Amaro & Sul & Primavera & $<\mathrm{LD}$ & $<\mathrm{LQ}$ \\
\hline Jaçanã & Sul & Primavera & $<\mathrm{LQ}$ & $<\mathrm{LQ}$ \\
\hline Penha & Leste & Primavera & $<\mathrm{LQ}$ & $\mathbf{5 , 3 5}$ \\
\hline Parque do Carmo & Leste & Primavera & & \\
& & & $<\mathrm{LQ}$ & $\mathbf{1 , 5 4}$ \\
\hline
\end{tabular}


Anexo 5 - Resultado das amostras de morango de acordo com local, zona, estação do ano

\begin{tabular}{|c|c|c|c|c|}
\hline Local & Zona & Estação & $\begin{array}{c}\text { Resultado } \\
\text { LC/UV }\end{array}$ & $\begin{array}{c}\text { Resultado } \\
\text { LC/MS/MS } \\
\text { (ng/g) }\end{array}$ \\
\hline $\begin{array}{c}\text { Vila Clementino } \\
\text { (controle) }\end{array}$ & Sul & outono & $<\mathrm{LD}$ & $<\mathrm{LD}$ \\
\hline Bela Vista & Centro & Outono & $<\mathrm{LD}$ & $<\mathrm{LQ}$ \\
\hline Vila Clementino & Sul & Outono & $<\mathrm{LD}$ & $<\mathrm{LQ}$ \\
\hline $\begin{array}{l}\text { Jardim São } \\
\text { Paulo }\end{array}$ & Norte & Outono & $<\mathrm{LD}$ & $<\mathrm{LQ}$ \\
\hline Santa Cecília & Centro & Outono & $<\mathrm{LD}$ & $<\mathrm{LQ}$ \\
\hline Saúde & Sul & Outono & $<\mathrm{LD}$ & $<\mathrm{LQ}$ \\
\hline Perdizes & Oeste & Outono & $<\mathrm{LD}$ & $<\mathrm{LQ}$ \\
\hline Pinheiros & Oeste & Outono & $<\mathrm{LD}$ & $<\mathrm{LQ}$ \\
\hline Vila Guilherme & Norte & Outono & $<\mathrm{LD}$ & $<\mathrm{LQ}$ \\
\hline Aricanduva & Leste & Outono & $<\mathrm{LD}$ & $<\mathrm{LQ}$ \\
\hline São Mateus & Leste & Outono & $<\mathrm{LD}$ & $<\mathrm{LQ}$ \\
\hline Jabaquara & Sul & Inverno & $<\mathrm{LD}$ & $<\mathrm{LD}$ \\
\hline Belém & Leste & Inverno & $<\mathrm{LD}$ & $<\mathrm{LQ}$ \\
\hline Barra Funda & Oeste & Inverno & $<\mathrm{LD}$ & $<\mathrm{LQ}$ \\
\hline Consolação & Centro & Inverno & $<\mathrm{LD}$ & $<\mathrm{LQ}$ \\
\hline Bom Retiro & Centro & Inverno & $<\mathrm{LD}$ & $<\mathrm{LQ}$ \\
\hline $\begin{array}{l}\text { Alto de } \\
\text { Pinheiros }\end{array}$ & Oeste & Inverno & $<\mathrm{LD}$ & $<\mathrm{LQ}$ \\
\hline Mirandópolis & Sul & Inverno & $<\mathrm{LD}$ & $<\mathrm{LQ}$ \\
\hline Itaquera & Leste & Inverno & $<\mathrm{LD}$ & $<\mathrm{LQ}$ \\
\hline Butantã & Oeste & Primavera & $<\mathbf{L D}$ & 1,42 \\
\hline Santana & Norte & Primavera & $<\mathrm{LD}$ & $<\mathrm{LQ}$ \\
\hline Santa Cecília & Centro & Primavera & $<\mathrm{LD}$ & $<\mathrm{LQ}$ \\
\hline
\end{tabular}




\begin{tabular}{|l|l|l|c|c|}
\hline \multicolumn{5}{|c|}{ Anexo 5 - Resultado das amostras de morango de acordo com } \\
& Zona & Estação & $\begin{array}{c}\text { Resultado } \\
\text { LC/UV }\end{array}$ & $\begin{array}{c}\text { Resultado } \\
\text { LC/MS/MS } \\
\text { (ng/g) }\end{array}$ \\
\hline Local & & & $<$ LD \\
\hline Santo Amaro & Sul & Primavera & $<$ LD & $<$ LD \\
\hline Jaçanã & Sul & Primavera & $<$ LD & $<$ LD \\
\hline Vila Maria & Norte & Primavera & $<$ LD & $<$ LQ \\
\hline Vila Pompéia & Oeste & Primavera & $<$ LD & $<$ LQ \\
\hline Tatuapé & Leste & Primavera & $<$ LD & $<$ LQ \\
\hline Vila Carrão & Leste & Primavera & $<$ LD & $<$ LQ \\
\hline Jardim América & Oeste & Primavera & $<$ LD & $\mathbf{0 , 9 5}$ \\
\hline Liberdade & Centro & Primavera & $<$ LD & $<$ LQ \\
\hline Cerqueira Cesar & Oeste & Primavera & $<$ LD & \\
\hline
\end{tabular}


PROGRAMA PAULISTA PP0304

"SUBPROGRAMA DE AGROTÓXICOS"

\section{Período: setembro/2003 a fevereiro/2004}

Abrangência: Estado de São Paulo

Modalidade de análise: fiscal de amostra única

Alimentos: hortifrutícolas: laranja, mamão, morango, pimentão, tomate. 


\section{"SUBPROGRAMA DE AGROTÓXICOS"}

Classificação dos Agrotóxicos

(grupo químico)

- Organoclorados

Caracterizados pela presença de cloro, carbono, hidrogênio e algumas vezes de oxigênio;

- Organofosforados

Ésteres dos ácidos fosfórico e fosfônico ou seus ácidos derivados;

- Piretróides

Ésteres do ácido crisântemo;

- Carbamatos

Ésteres dos ácidos

n-metilcarbâmico e

n-n-dimetilcarbâmico;

- Ditiocarbamatos

Compostos derivados do ácido ditiocarbâmico. 


\section{"SUBPROGRAMA DE AGROTÓXICOS"}

Ditiocarbamatos - grupos

> Os ditiocarbamatos são subdivididos nos grupos:

-Dimetilditiocarbamatos (DMDC): ferbam, ziram e tiram;

-Etilenobisditiocarbamatos (EBDC): mancozebe, manebe, zinebe e metiram;

-Monometilditiocarbamato: metam sódico;

-Propilenobisditiocarbamato: propinebe. 


\section{"SUBPROGRAMA DE AGROTÓXICOS" \\ Classificação toxicológica' (MS)}

- Classe I - Extremamente tóxicos

- Classe II - Altamente tóxicos

- Classe III - Moderadamente tóxicos

- Classe IV - Pouco tóxicos

- -Ditiocarbamatos

Mancozebe, manebe, metiram e propinebeClasse III- moderadamente tóxicos

-Tiram e metam sódico - Classe II - altamente tóxicos.

- Organofosforados

- Metamidofós - Classe I-

-Parationa-metílica - Classe I

-Clorpirifós-etílico - Classe II

-Profenofós - Classe II

-Acefato - Classe III

- Piretróide

-Deltametrina - Classe III

- Éster de diol cíclico clorado

-Endossulfam - Classe II

- Isoftalonitrila

Clorotalonil - Classe I 


\section{"SUBPROGRAMA DE AGROTÓXICOS"}

\section{Agrotóxicos analisados}

Métodos analíticos para determinação de

\section{resíduos}

- Ditiocarbamatos em CS2 - Espectrofotometria U.V. visível (Their and Zeumer 1987)

- Método Multi-resíduo (Analytical Methods for Pesticide Residues in Foodstufts 1996; Kok 1992)

- Hexaclorobenzeno, aldrin, endrin, dieldrin, DDT total (op' DDE, pp'DDE, op'DDT, pp'DDT, op'DDD, $p p^{\prime}(D D D)$, aletrina, bioaletrina, bifentrina, ciflutrina, clorotalonil,cipemetrina, deltametrina, lambdacialotrina, permetrina, procloraz, esfenvalerato, heptacloro, heptacloro epóxido, dodecacloro, endossulfam I, endossulfam II, sulfato de endossulfam, captana, dicofol, iprodiona, procimidona, propargito, vinclozolina Cromatografia a gás com detector de captura de elétrons (ECD);

- Acefato, azinfós etílico, carbofenotiona, clorfenvinfós, etiona, parationa etílica, parationa metílica, clorpirifós etílico, clorpirifós metílico, profenofós, diazinon, fenamifós, pirazofós, terbufós, metamidofós, diclorvos, disulfotona, fentiona, fentoato, pirimifós etílico, pirimifós metílico, tetradifona, etoprofós, dimetoato, etrinfós, metidadiona, monocrotofós, folpete, forato, malationa, mevinfós - Cromatografia a gás com detector fotométrico de chama (FPD) ou de nitrogênio e fósforo (NPD);

- Carbofurano, carbaril - Cromatografia a líquido de alta eficiência detector de UV ou de fluorescência 


\section{"SUBPROGRAMA DE AGROTÓXICOS" Legislação e normas}

> Referentes ao registro e avaliação de agrotóxicos

-Decreto 4.074, 04/01/02;

-Resolução RDC no 5, de 14/10/99 ANVISA/MS

-Portaria IBAMA no 84, 15/10/96

> Referentes aos LMR nos alimentos

-Resolução RE no 165 de 29/08/2003 da ANVISA/MS, D.O.U. 02/09/2003

\section{LMR - Limite Máximo de Resíduo ( $\mathrm{mg} / \mathrm{kg}$ )}

LMR - quantidade máxima de resíduo de agrotóxico ou afim oficialmente aceita no alimento, em decorrência da aplicação adequada numa fase específica, desde sua produção até o consumo, expressa em partes (em peso) do agrotóxico, afim ou seus resíduos por milhão de partes de alimento (em peso) (ppm ou $\mathrm{mg} / \mathrm{kg}$ )

\section{IDA - Ingestão Diária Aceitável (mg/kg/p.c.)}

Ingestão Diária Aceitável (IDA)- é a quantidade máxima que ingerida diariamente, durante toda a vida, parece não oferecer risco apreciável à saúde, à luz dos conhecimentos atuais. É expressa em mg do agrotóxico por kg de peso corpóreo $(\mathrm{mg} / \mathrm{kg} / \mathrm{p} . \mathrm{c}$. 


\section{"SUBPROGRAMA DE AGROTÓXICOS" \\ RESULTADOS amostras $(n=125)$}

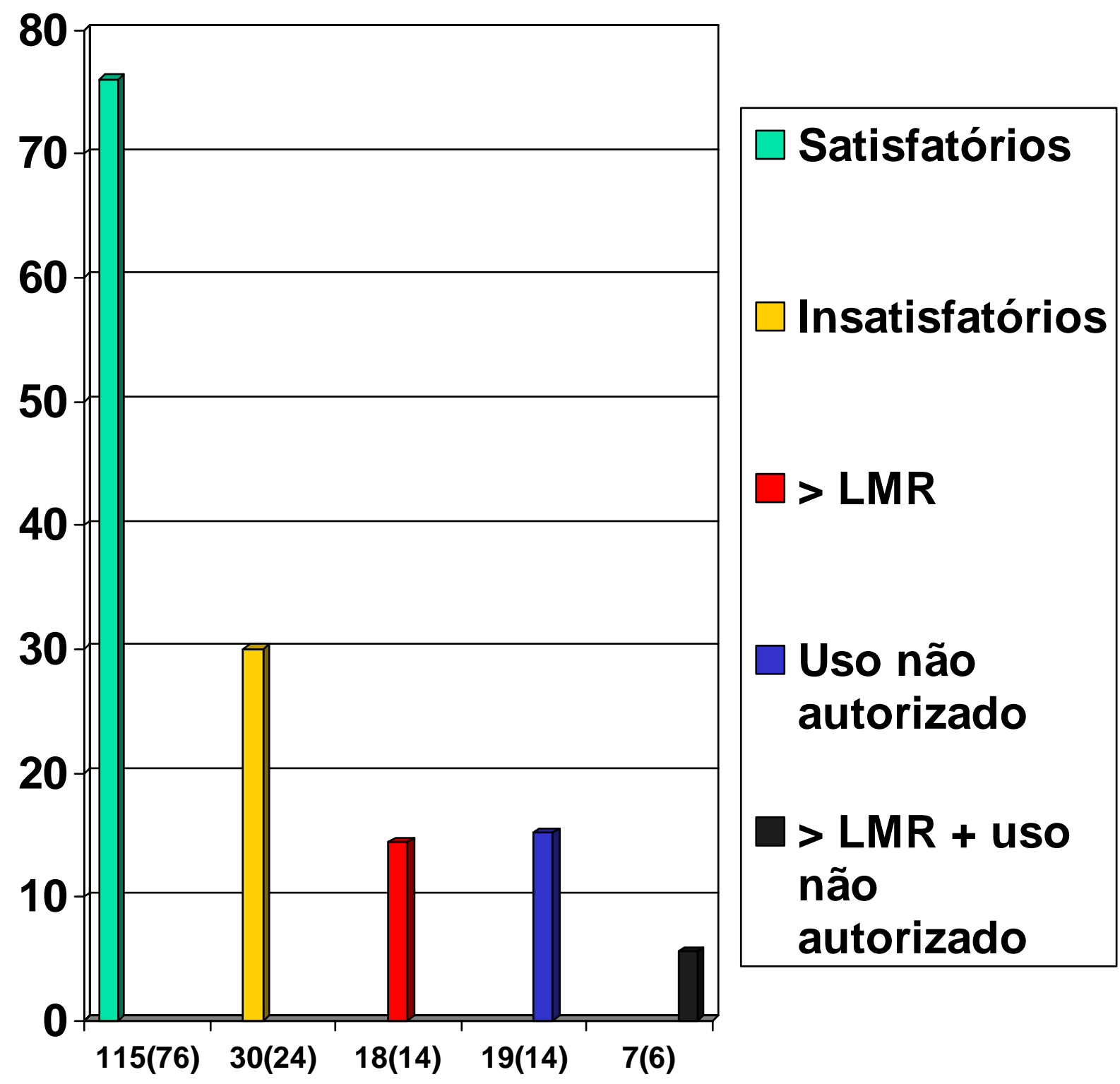




\section{"SUBPROGRAMA DE AGROTÓXICOS" RESULTADOS}

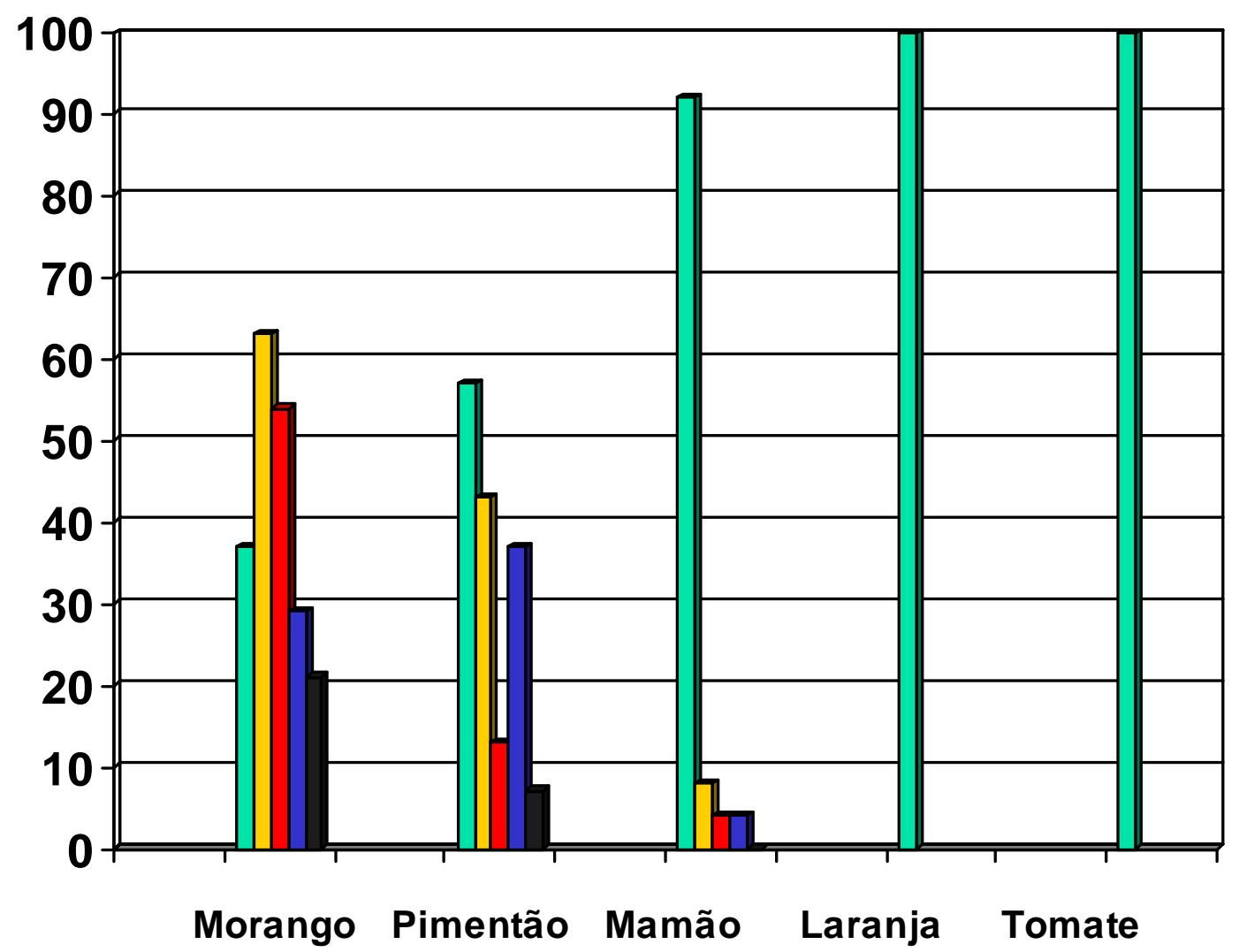
$\square$ Satisfatórias
$\square$ Insatisfatórias
$\square>$ LMR
$\square$ Uso não autorizado
$\square$ > LMR + uso não autorizado 


\section{"SUBPROGRAMA DE AGROTÓXICOS" \\ RESULTADOS - MORANGO $(n=24)$}

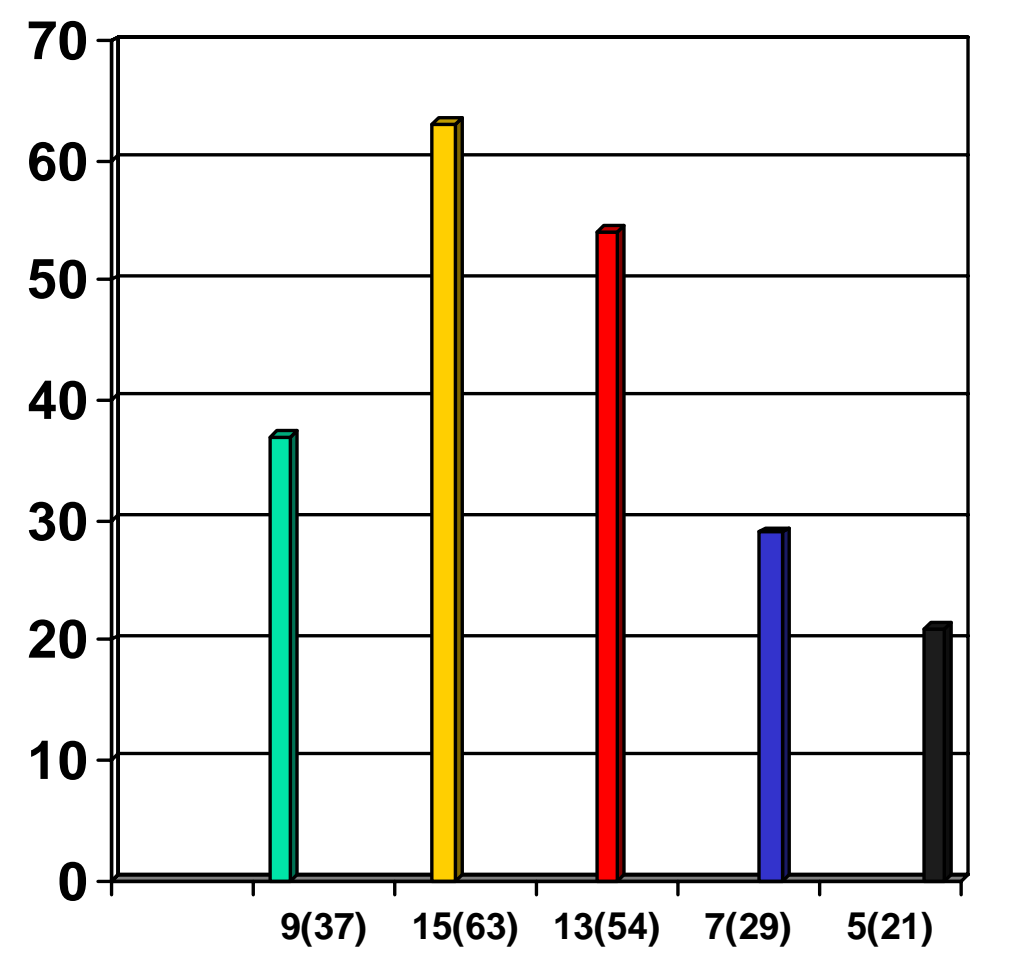

\begin{tabular}{|l|}
\hline Satisfatórias \\
$\square$ Insatisfatórias \\
$\square>$ LMR \\
$\square$ Uso não \\
autorizado \\
$\begin{array}{c}\text { > LMR + uso não } \\
\text { autorizado }\end{array}$ \\
\hline
\end{tabular}




\section{"SUBPROGRAMA DE AGROTÓXICOS" \\ RESULTADOS - MORANGO \\ $(n=24)$}

\section{- > LMR}

- Ditiocarbamatos $(n=13)$

- $L M R=0,2 \mathrm{mg} / \mathrm{kg}$ de $\mathrm{CS}_{2}$

- Uso não autorizado

- Organofosforados

- -Metamidofós $(n=3)$

- -Parationa-metílica $(n=1)$

- -Clorpirifós-etílico $(n=1)$

- -Acefato $(n=1)$

- Éster de diol cíclico clorado

- Endossulfam $(n=1)$ 


\section{"SUBPROGRAMA DE AGROTÓXICOS" RESULTADOS - MAMÃO $(n=24)$}

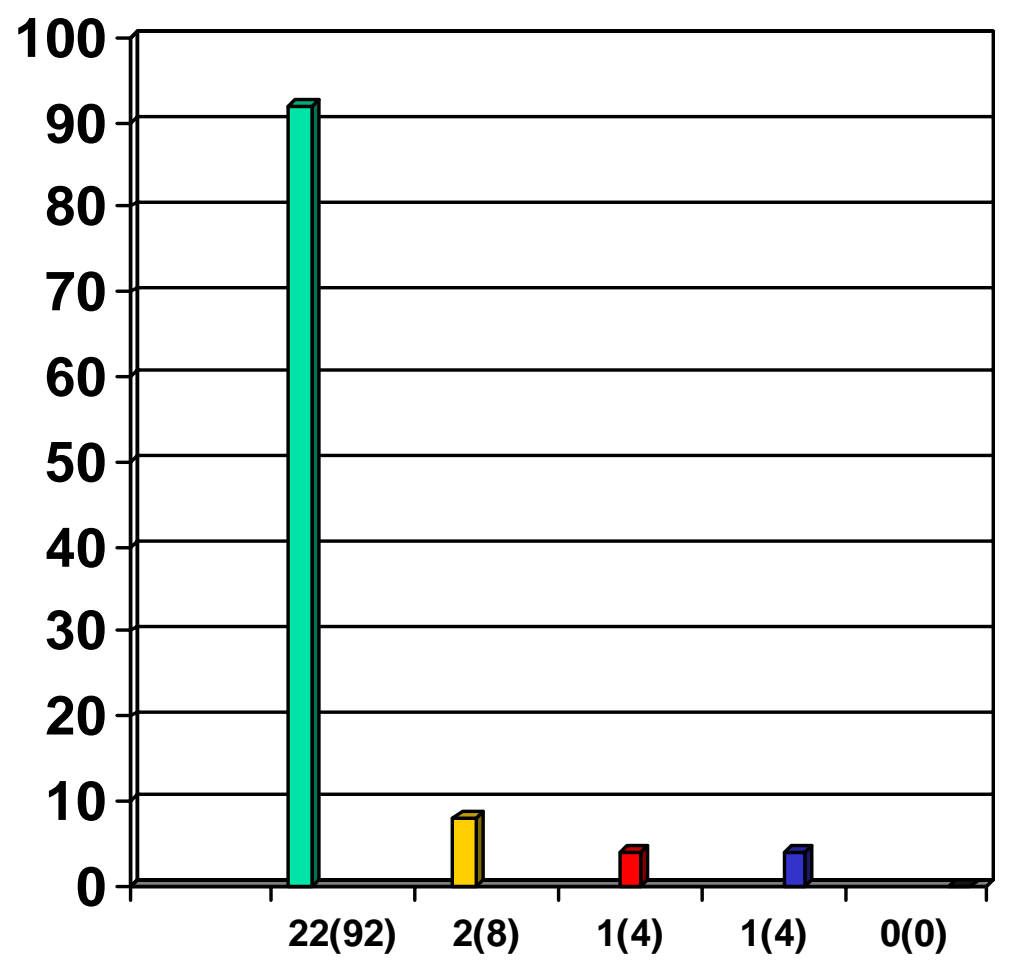

$\square$ Satisfatórias

$\square$ Insatisfatórias

$\square>$ LMR

口 Uso não autorizado

口 > LMR + uso não autorizado 


\section{"SUBPROGRAMA DE AGROTÓXICOS" RESULTADOS - MAMÃO $(n=24)$}

\section{- > LMR}

- Isoftalonitrila

-Clorotalonil $(n=1)$

- $\mathrm{LMR}=0,1 \mathrm{mg} / \mathrm{kg}$

- Uso não autorizado

- Piretróide

- -Deltametrina $(n=1)$ 


\section{"SUBPROGRAMA DE AGROTÓXICOS" RESULTADOS - PIMENTÃO $(n=30)$}

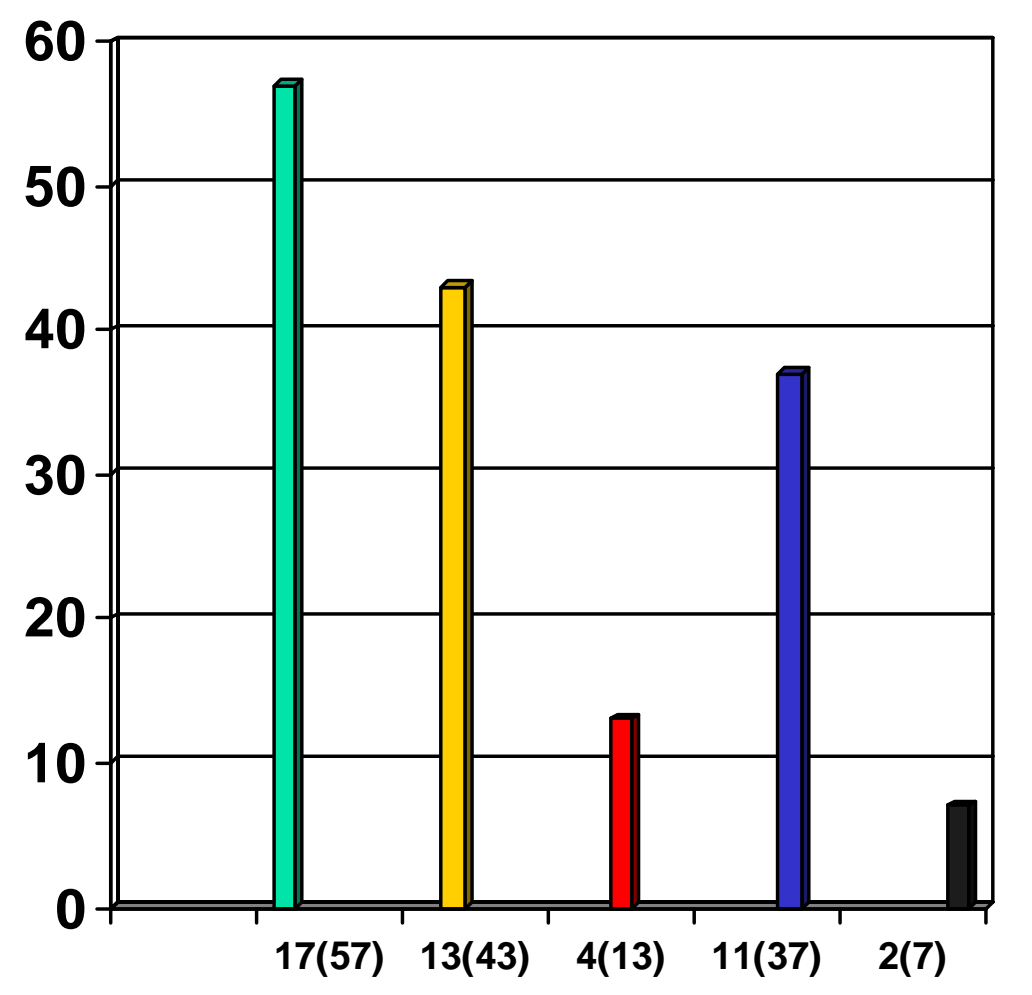

$\square$ Satisfatórias

$\square$ Insatisfatórias

$\square>$ LMR

๑ Uso não autorizado

口 > LMR + uso não autorizado 


\section{"SUBPROGRAMA DE AGROTÓXICOS" RESULTADOS - PIMENTÃO $(n=30)$}

\section{- > LMR}

- Ditiocarbamatos $(n=4)$

- $\operatorname{LMR}=1,2 \mathrm{mg} / \mathrm{kg}$ de $\mathrm{CS}_{2}$

- Uso não autorizado

- Organofosforados

- Metamidofós $(n=8)$

- -Profenofós $(n=2)$

- -Clorpirifós-etílico $(n=1)$ 


\section{"SUBPROGRAMA DE AGROTÓXICOS"}

\section{CONCLUSÕES}

- Os resultados insatisfatórios com resíduos acima dos LMR permitidos pela legislação brasileira permitiram supor o uso inadequado de agrotóxicos pelos agricultores, ou seja, a não obediência das Boas Práticas Agrícolas;

-Foram encontrados resíduos de ditiocarbamatos com maior fregüência nas amostras de morango e pimentão, e de clorotalonil em uma amostra de mamão;

- Proporcionou também uma avaliação quanto ao uso de agrotóxicos não autorizado para as culturas estudadas;

-Foram detectados resíduos de alguns organofosforados: profenofós, metamidofós e clorpirifós-etílico, nas amostras de pimentão e acefato, clorpirifós-etílico, parationa-metílica e metamidofós em morango, endossulfam em morango e deltametrina em mãmão, todos de uso não autorizado para as citadas culturas;

- Forneceu subsídios para aplicação de ações de prevenção de risco à saúde da população;

-Os produtos insatisfatórios foram inutilizados pela Vigilância Sanitária;

-Os resultados foram encaminhados ao órgão competente do Ministério da Agricultura para as providências cabíveis juntos aos produtores. 


\section{PROGRAMA PAULISTA PP0304}

\section{METAIS PESADOS}

> METAIS PESADOS

> CHUMBO $(\mathrm{Pb})$ NO LEITE

Ingestão de alimentos, partículas ou água contaminados com chumbo.

Efeito cumulativo

Espectrometria de absorção atômica com chama (AOAC International 1995)

Limite máximo de tolerância no leite fluído-0,1 mg/kg (Brasil 1998)

> MERCÚRIO NO PEIXE

> Pela água, através da superfície respiratória ou adsorção de água na superfície do corpo

> Ingestão de alimentos, partículas ou água através do sistema digestivo

> Metilmercúrio introduzido nos organismos e tem efeito cumulativo.

> Espectrometria de absorção atômica com gerador de vapor frio (Zenebon 1995)

> Limite máximo de tolerência - $0,5 \mathrm{mg} / \mathrm{kg}$ peixes não predadores e 1,0 mg/kg em peixes predadores(Brasil 1988) 


\section{PROGRAMA PAULISTA PP0304}

\section{AFLATOXINA M1 (Micotoxina)}

\section{- AFLATOXINA M1 NO LEITE}

Micotoxinas são metabólitos secundários tóxicos, produzidos por alguns fungos que são chamados de fungos toxigênicos. Os principais são: Aspergillus, Penicillium e Fusarium. Mamíferos que ingerem alimentos contaminados com aflatoxina (AFB1 e AFB2) secretam em seus leites micotoxinas AFM1 e AFM2).

Coluna de imunoafinidade e cromatografia em camada delgada.

A legislação brasileira estabelece limite de tolerância de $0,5 \mu \mathrm{g} / \mathrm{L}$ de aflatoxina M1 no leite (Brasil 2002) 


\section{PROGRAMA PAULISTA PP0304}

\section{AGROTÓXICOS NO LEITE}

- O leite pode conter resíduos de agrotóxicos não intencionais em decorrência do consumo de água pastagens e rações contaminadas ou pelo uso dos mesmos no gado para controle de ectoparasitas.

- Método multi-resíduos para produtos gordurosos (Steiwandter 1982)

- LIMITE DE TOLERÂNCIA $6 \mu \mathrm{g} / \mathrm{kg}$ para aldrin, $8 \mu \mathrm{g} / \mathrm{kg}$ para dieldrin, $4 \mu \mathrm{g} / \mathrm{kg}$ para heptacloro, $40 \mu \mathrm{g} / \mathrm{kg}$ para DDT e metabólitos (Brasil 1999) 


\section{PROGRAMA PAULISTA PP0304 \\ FÍSICO-QUÍMICOS ÁGUA MINERAL E}

\section{GELO}

- Caracteres organolépticos:

Aspecto, odor - Método subjetivo

Cor - Comparação óptica instrumental

- Turbidez - Nefelométrico

- Durezas - Titulometria

- Fluoretos (em F) - Espectrotofometria-UV visível

- Nitrato(em N)- Espectrofotometria UV

- Amônia (em NH3)- Espectrofotometria U.V. visível ou potenciométrico

- Ferro -Espectrofotometria U.V. visível

- Cloretos- Titulométria

- Sulfatos (em $\mathrm{SO}_{3}$ )- Gravimétrico

- Sólidos totais dissolvidos- Gravimétrico, condutivimétrico ou turbidimétrico.

(Normas analíticas do IAL 1985; American Public Health Association Water Works Association, Water Environmental Federation 1995)

Limites de tolerância -

Portaria 1469 29/12/2000 ANVISA/MS- em vigor na época da realização dos ensaios Portaria 518 25/03/04 ANVISA/MS - atual 


\section{Obrigada a todos}

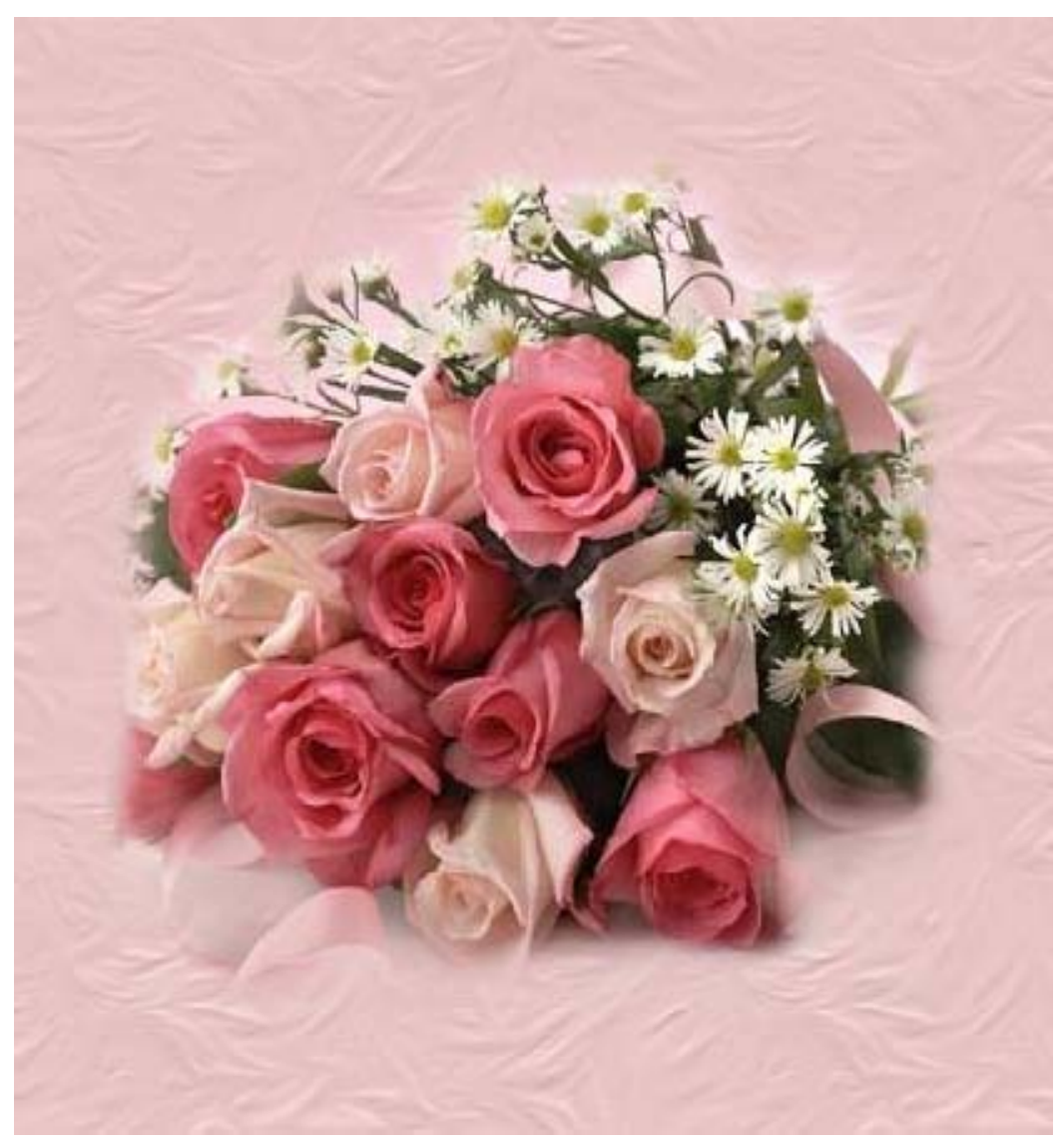




\section{Etilenobisditiocarbamatos (EBDC)}

> Mancozebe: Etilenobisditiocarbamato de manganês e zinco (complexo polimérico)

$$
\mathbf{S}
$$

CH2 - NH $-\stackrel{\text { II }}{\mathrm{C}}-\mathrm{S}$

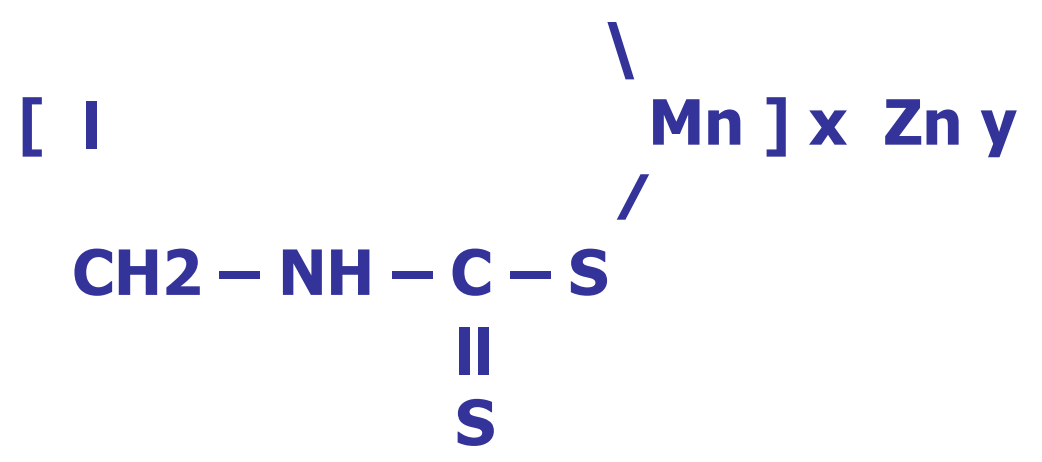

> Manebe: Etilenobisditiocarbamato de manganês $\mathbf{S}$

$$
\begin{gathered}
\mathrm{CH} 2-\mathrm{NH}-\mathrm{C}-\mathrm{S} \\
\mathrm{CH} 2-\mathrm{NH}-\mathrm{C}-\mathrm{S} \\
\text { II }
\end{gathered}
$$


Portaria 10 da SNVS de 08/03/85 e atualizações pela ANVISA/MS*

Em vigor até 01/09/03
RE $n^{\circ} 165$ 29/08/03**

D.O.U. de 02/09/93

ANVISA/MS atual

\section{Ditiocarbamatos}

\begin{tabular}{ll|l|ll} 
Mancozebe & Manebe & Propinebe Tiram & Ziram & $\mathbf{C S}_{2}$
\end{tabular}

\begin{tabular}{|c|c|c|c|c|c|c|c|}
\hline $\begin{array}{l}\text { Cultura } \\
\text { (frutas) }\end{array}$ & $\begin{array}{r}\text { LMR } \\
(\mathrm{mg} / \mathrm{kg})\end{array}$ & $\begin{array}{r}\text { LMR } \\
(\mathrm{mg} / \mathrm{kg})\end{array}$ & $\begin{array}{r}\text { LMR } \\
(\mathrm{mg} / \mathrm{kg})\end{array}$ & $\begin{array}{r}\text { LMR } \\
(\mathrm{mg} / \mathrm{kg})\end{array}$ & $\begin{array}{r}\text { LMR } \\
(\mathrm{mg} / \mathrm{kg})\end{array}$ & $\begin{array}{r}\text { LMR } \\
(\mathrm{mg} / \mathrm{kg})\end{array}$ & $\begin{array}{l}\text { Ingrediente } \\
\text { ativo }\end{array}$ \\
\hline Banana & & 1,0 & & 1,0 & & 1,0 & Mancozebe \\
\hline Citros & 0,5 & 1,0 & & & 7,0 & 2,0 & Mancozebe \\
\hline Goiaba & & & & & 3,0 & & \\
\hline Maçã & & 3,0 & 1,0 & & & 2,0 & $\begin{array}{l}\text { Metiram e } \\
\text { Mancozebe }\end{array}$ \\
\hline Mamão & 5,0 & 7,0 & & & & 3,0 & Mancozebe \\
\hline Manga & 2,0 & & & & & 1,0 & Mancozebe \\
\hline Melância & & 1,0 & & & & 0,3 & Mancozebe \\
\hline Melão & 0,5 & 1,0 & & & & 1,0 & Mancozebe \\
\hline Morango $^{a}$ & & 1,0 & & & & 0,2 & Metam \\
\hline Pêra & & 3,0 & & & & 3,0 & Mancozebe \\
\hline Pêssego & & 3,0 & & & & 2,0 & Mancozebe \\
\hline Uva & & 3,0 & 2,0 & & 5,0 & 3,0 & Mancozebe \\
\hline \multicolumn{8}{|l|}{ (Vegetais) } \\
\hline Alface & & 10,0 & & & & 6,0 & Manebe \\
\hline Batata $^{\text {b }}$ & & 0,1 & & 0,5 & 0,1 & 0,3 & Propinebe \\
\hline Berinjela & & & & & & 0,5 & Mancozebe \\
\hline Beterraba & & 0,1 & & & & 0,3 & Mancozebe \\
\hline Brócolis & 0,5 & & & & & 0,5 & Mancozebe \\
\hline Cenourab $^{b}$ & & 1,0 & & & & 0,3 & Mancozebe \\
\hline Chicória & & 10,0 & & & & & \\
\hline Couve & 0,5 & & & & & 1,0 & Mancozebe \\
\hline Couve-flor & 0,5 & & & & & 0,5 & Mancozebe \\
\hline Espinafre & & 10,0 & & & & & Mancozebe \\
\hline Milhoc & & & & 0,5 & & 0,3 & Tiram \\
\hline Pepino & & 0,5 & & & & 0,3 & Mancozebe \\
\hline Pimentão & 1,0 & & 1,0 & & & 1,0 & Mancozebe \\
\hline Repolho & 0,5 & 10,0 & & & & 1,0 & Mancozebe \\
\hline Tomate $^{b}$ & & 1,0 & & & 3,0 & 2,0 & Mancozebe \\
\hline
\end{tabular}




\begin{tabular}{|c|c|c|c|c|c|c|c|}
\hline & Mancozebe & Manebe & Propinebe & Tiram & Ziram & & $\begin{array}{l}\text { iocarbamatos } \\
\mathrm{CS}_{2}\end{array}$ \\
\hline $\begin{array}{l}\text { Cultura } \\
\text { (cereais } \\
\text { outras) }\end{array}$ & $\begin{array}{l}\text { LMR } \\
(\mathrm{mg} / \mathrm{kg})\end{array}$ & $\begin{array}{l}\text { LMR } \\
(\mathrm{mg} / \mathrm{kg})\end{array}$ & $\begin{array}{l}\text { LMR } \\
(\mathrm{mg} / \mathrm{kg})\end{array}$ & $\begin{array}{c}\text { LMR } \\
(\mathrm{mg} / \mathrm{kg})\end{array}$ & $\begin{array}{r}\text { LMR } \\
(\mathrm{mg} / \mathrm{kg})\end{array}$ & $\begin{array}{c}\text { LMR } \\
(\mathrm{mg} / \mathrm{kg})\end{array}$ & $\begin{array}{c}\text { Ingrediente } \\
\text { ativo }\end{array}$ \\
\hline Abóbora & & 1,0 & & & & 1,0 & Mancozebe \\
\hline Aipo & & 1,0 & & & & 0,5 & Manebe \\
\hline Algodão ${ }^{c}$ & 0,2 & & & 0,5 & & 0,3 & Tiram \\
\hline Alho & & & & 0,5 & & 0,1 & Mancozebe \\
\hline Amendoim & 0,2 & 0,2 & & 0,5 & 7,0 & 0,3 & Tiram \\
\hline Arroz $^{c}$ & & 1,0 & & 0,5 & 0,2 & 3,0 & Mancozebe \\
\hline Aveia & & & & 0,5 & & 0,3 & Tiram \\
\hline Café & & 1,0 & & & 3,0 & 0,3 & Mancozebe \\
\hline Cebola & & 3,0 & 1,0 & 0,5 & & 0,5 & Propinebe \\
\hline Cevada & & 0,2 & & 0,5 & & 1,0 & Mancozebe \\
\hline Ervilha & & & & 0,5 & & 0,3 & $\begin{array}{l}\text { Mancozebe e } \\
\text { Tiram }\end{array}$ \\
\hline Feijão $^{c}$ & 0,5 & 0,05 & 0,2 & 0,5 & & 0,3 & $\begin{array}{l}\text { Mancozebe e } \\
\text { Tiram }\end{array}$ \\
\hline Feijão-vagem & & & & & & 0,3 & Mancozebe \\
\hline Soja & 1,0 & & & 0,5 & & 0,3 & Tiram \\
\hline Trigo & 0,5 & 2,0 & & 0,5 & 0,2 & 1,0 & Mancozebe \\
\hline
\end{tabular}

